VILNIAUS GEDIMINO TECHNIKOS UNIVERSITETAS

Jurgita LIEPONIENE

\title{
E. MOKYMOSI REZULTATŲ VERTINIMO TECHNOLOGIJŲ TYRIMAS
}

DAKTARO DISERTACIJA

TECHNOLOGIJOS MOKSLAI,

INFORMATIKOS INŽINERIJA (07T)

Vilnius TECHNIKA 2012 
Disertacija rengta 2008-2012 metais Vilniaus Gedimino technikos universitete.

\section{Mokslinis vadovas}

doc. dr. Regina KULVIETIENE (Vilniaus Gedimino technikos universitetas, technologijos mokslai, informatikos inžinerija - 07T).

VGTU leidyklos TECHNIKA 1992-M mokslo literatūros knyga http://leidykla.vgtu.lt

ISBN 978-609-457-133-6

(C) VGTU leidykla TECHNIKA, 2012

(C) Jurgita, Lieponienè, 2012

jurgita.lieponiene@gmail.com 
VILNIUS GEDIMINAS TECHNICAL UNIVERSITY

Jurgita LIEPONIENE

THE RESEARCH OF E-LEARNING RESULTS' ASSESSMENT TECHNOLOGIES

DOCTORAL DISSERTATION

TECHNOLOGICAL SCIENCES,

INFORMATICS ENGINEERING (07T)

Vilnius TECHNIKA 2012 
Doctoral dissertation was prepared at Vilnius Gediminas Technical University in 2008-2012.

\section{Scientific Supervisor}

Assoc Prof Dr Regina KULVIETIENĖ (Vilnius Gediminas Technical University, Technological Sciences, Informatics Engineering - 07T). 



\section{Reziumè}

Disertacijoje nagrinejjamos e. mokymosi rezultatu vertinimo problemos, aukštojo mokslo kaitos kontekste. Pagrindinis tyrimo objektas yra automatinis pažymių konvertavimas iš vienos vertinimo skalès ị kitą. Šis objektas yra svarbus igyvendinant Bolonijos proceso nuostatas. Pagrindinis disertacijos tikslas sukurti vertinimų automatinio konvertavimo iš vienos vertinimo skalès $i$ kitą modelius.

Darbe sprendžiami keli pagrindiniai uždaviniai: atlikti tyrimų e. mokymosi rezultatų vertinimo technologijų srityje analizę; išanalizuoti studijų rezultatų modelius ir sistemas; sukurti vertinimų konvertavimo iš vienos vertinimo skalès i kitą modelius ir juos realizuojančius algoritmus; atlikti sukurtų vertinimo konvertavimo modelių eksperimentini tyrimą; integruoti vertinimų konvertavimo modeli i i e. mokymosi sistemą.

Ivadiniame skyriuje aptariama tiriamoji problema, darbo aktualumas, aprašomas tyrimų objektas, formuluojamas darbo tikslas bei uždaviniai, aprašoma tyrimų metodika, darbo mokslinis naujumas, darbo rezultatų praktinè reikšmé, ginamieji teiginiai. Ivado pabaigoje pristatomos disertacijos tema autoriaus paskelbtos publikacijos ir pranešimai konferencijose bei disertacijos struktūra.

Pirmasis skyrius skirtas literatūros apžvalgai. Jame pateikta tyrimų e. mokymosi rezultatų vertinimo technologijų srityje analizè, pagrindžiamas nagrinèjamos temos aktualumas. Skyriaus pabaigoje formuluojamos išvados.

Antrajame skyriuje pateikta ịvairių šalių studijų rezultatų vertinimo sistemų analizè, nagrinejjama ECTS vertinimo skalè ir aptariamos šios vertinimų skalès taikymo problemos. Skyriaus pabaigoje parenkama pažymių konvertavimo iš vienos vertinimo skalès į kitą metodika ir formuluojamos išvados.

Trečiajame ir ketvirtajame skyriuose aprašomi sukurti pažymių konvertavimo modeliai ir juos realizuojantys algoritmai, ivertinamas sukurtu algoritmų sudètingumas, pristatomi modelių eksperimentinio tyrimo rezultatai.

Penktajame skyriuje nagrinejjamas vertinimų konvertavimo modelio integravimas i e. mokymosi sistemas, pasirenkamas pažymių konvertavimo modelis, aptariami pažymių konvertavimo modelio integravimo ị Moodle sistemą klausimai.

Disertacijos tema paskelbta 12 straipsnių: 5 straipsniai recenzuojamuose mokslo žurnaluose, 2 - konferencijų medžiagoje, referuotoje ISI duomenų bazèje, 1 - tarptautinès konferencijos medžiagoje, 2 - respublikinių konferencijų medžiagoje, 2 - kituose recenzuojamuose leidiniuose. Disertacijos tema perskaityta 12 pranešimų respublikinèse ir tarptautinese konferencijose. 


\section{Abstract}

The doctoral thesis analyses the issues of the grading of e-learning results in the context of higher education changes. The main object of analysis is the automatic conversion of grades from one grading scale to another. The doctoral thesis mainly aims at developing the models of automatic grades conversion from one grading scale to another.

The following main objectives are solved in the thesis: analysis of researches performed in the area of technologies of e-learning results grading; performance of analysis of models and grading systems of study results; development of the models of grading conversion from one grading scale to another as well as the algorithms, implementing such models; experimental analysis of developed grading conversion models; integration of developed grading conversion model into e-learning system.

The introduction discusses analyzed problem, relevance of work, description of analysis object, formulation of the aim and objectives of thesis, description of research methodology, the scientific novelty of work, practical significance of work results and defensive statements.

The first section is dedicated to the review of literature sources. It includes the analysis of researches in the area of e-learning results grading technology and justification of the relevancy of analyzed topic. The second section provides the analysis of grading systems of studies results in various countries, the ECTS grading scale is analyzed and the issues of the application of this grading scale are discussed. The methodology of grading conversion from one grading scale to another and conclusions are provided at the end of the section.

The third and fourth sections describe the developed grading conversion models and their respective algorithms, the experimental analysis of developed models is performed.

The fifth section analyzes the integration of grading conversion model into e-learning systems, the grading conversion model suitable for e-learning systems is selected, the questions of the integration of grading conversion model into Moodle are discussed.

12 articles were published on the topic of doctoral thesis: 5 articles were published in scientifics magazines, 2 articles were published in conference-type material referred to in the ISI database, 1 article - international conference-type material and 2 articles - in national conference-type material, 2 articles - in other peer-reviewed editions. 12 statements on the topic of doctoral thesis were made at national and international conferences. 


\section{Sąvokos}

Algoritmas

Algoritmo struktūrinè schema

Algoritmo sudetingumas

Diskretieji atsitiktiniai dydžiai

Diskretieji skirstiniai

Duomenų bazé

Duomenu baziu valdymo sistema
Tiksliai apibrèžta skaičiavimo procedūra, kuria, imdami pradinius duomenis ir atlikę baigtini skaičių operacijų, gauname rezultatą (Dagienè et al. 2009).

Algoritmo vaizdavimo būdas (Baniulis et al. 2005).

Atliekamų bazinių veiksmų skaičius.

Atsitiktiniai dydžiai, kurie gali igyti tik baigtinę arba skaičiają (suskaičiuojamą) aibę reikšmių (Čekanavičius et al. 2001).

Diskrečiųuu atsitiktinių dydžių skirstiniai (Čekanavičius et al. 2001).

Duomenų (ịrašų) rinkinys, susistemintas ir sutvarkytas pagal tam tikras taisykles, kad būtų patogu naudotis (Dagienè et al. 2009).

Duomenų bazès programinè sąsaja, kuri suteikia galimybę naudotojui efektyviai manipuliuoti duomenimis; pateikti paieškos užklausas, rikiuoti, pildyti naujais duomenimis, pašalinti arba atnaujinti duomenis (Dagienè et al. 2009). 
E. mokymasis (e-learning)

E. mokymosi sistema

E. mokymosi rezultatu vertinimo technologijos

Išorinis raktas

Ivertinimas (evalution)

Iskiepis

Kvantilio reikšmè

Loginè duomenu bazès schema

Nuotolinio mokymosi atvejis, kai mokymosi veiklai praplèsti, pagerinti ir sustiprinti yra naudojamos tinklinès informacinès komunikacinès technologijos (Uden 2004). Mokymasis, kai jo efektyvumui didinti naudojamos informacinès ir komunikacinès technologijos (Dagienè et al. 2008).

Integruotų kompiuterinių priemonių visuma, suteikianti galimybę mokyti ir mokytis elektroninėmis priemonèmis, naudojant kompiuteri ir internetą (Gerhard et al. 2002).

Kompiuterinių priemonių visuma, suteikianti galimybę elektroniniu būdu, vertinti pasiektus mokymosi rezultatus.

Lentelès laukas arba lauku rinkinys, kuris kitoje lenteleje (ar net toje pačioje) yra pirminis raktas (Sekliuckis et al. 2004).

Kokių nors objektų, metodų, sistemų ar požymių pripažinimas tinkamais veiklai, konstrukcijoms ar kitam tikslui (Jovaiša 2007).

Programa, praplečianti standartinị sistemos funkcionalumą.

Atsitiktinio dydžio $\beta$ lygmens kvantilio reikšme ( $\beta$ kvantilio reikšme) vadinsime skaičiu $\mathrm{y}_{\beta}$, tenkinanti nelygybes: $P\left(X<y_{\beta}\right) \leq \beta \leq P\left(X \leq y_{\beta}\right)$ (Čekanavičius et al. 2001). Tarkime, F yra skirstinio funkcija, tuomet jos $\beta$ lygmens kvantilio reikšme vadinamas dydis $\mathrm{y}_{\beta}$, su kuriuo tenkinama lygybè $F\left(y_{\beta}\right)=\beta$ (Aksomaitis 2002).

Formalus duomenų bazès struktūros aprašas, sudarytas atsižvelgus i konkretaus duomenų modelio savybes, bet neatsižvelgus ị konkrečios duomenų bazių valdymo sistemos, naudojamos tai bazei igyvendinti, ypatumus ( $\mathrm{Pa}-$ tašienè 2008).

\footnotetext{
Mokymosi pasiekimai (learning outcomes) Trumpas aprašymas, ką moksleivis ar studen-
tas turi žinoti arba gebėti atlikti baigęs moky-
mosi dalyką ar modulio programą (Laužackas

Mokymosi pasiekimai (learning outcomes) Trumpas aprašymas, ką moksleivis ar studen-
tas turi žinoti arba gebeti atlikti baigęs moky-
mosi dalyką ar modulio programą (Laužackas

Mokymosi pasiekimai (learning outcomes) Trumpas aprašymas, ką moksleivis ar studen-
tas turi žinoti arba gebėti atlikti baigęs moky-
mosi dalyką ar modulio programą (Laužackas 2005).
}

viii 
Pirminis raktas

Tolydieji atsitiktiniai dydžiai

Tolydieji skirstiniai

Vertinimas (assessment)

Vertinimo sistema
Lentelès laukas arba lauku rinkinys, kuriu igyjamos reikšmès yra nepasikartojančios (Sekliuckis et al. 2004).

Atsitiktiniai dydžiai, kurie gali iggyti reikšmes iš bet kurio realiuju skaičiu intervalo.

Tolydžiujų atsitiktinių dydžių skirstiniai (Čekanavičius et al. 2001).

Procesas, kurio metu renkami ir gaunami patvirtinimai apie besimokančiojo mokymąsi, pasiekimus ir igytas kompetencijas (Laužackas 2005).

Ugdytiniu mokymo ir mokymosi rezultatu išreiškimo ir ifforminimo tvarkos organizavimas (Rajeckas 1999). 



\section{Žymèjimai}

\section{Simboliai}

$T_{i}$ - numatytas $i$-tasis kurso vertinimo laiko momentas;

$L$ - vertinimo skalès ilgis;

$L_{3}$ - studentu pasiekti mokymosi rezultatai procentais;

$L_{h}$ - studentų nepasiekti mokymosi rezultatai procentais;

$K$ - kokybès faktorius;

$a$ - santykinis išmokimas;

$a_{i}-i$-tasis teigiamas pažymys vertinimo skalèje $A$;

$b_{j}-j$-tasis teigiamas pažymys vertinimo skalèje $B$;

$p_{A i}$ - vertinimo skalès $A$ i-tojo teigiamo pažymio igijimo tikimybé;

$p_{B j}$ - vertinimo skalès $B j$-tojo teigiamo pažymio igijimo tikimybé;

$p_{i j}$ - tikimybè, kad studento žinios ir gebèjimai vertinimo skalèje $A$, ịvertinti pažymiu su indeksu $i, B$ vertinimo skaleje bus ịvertinti pažymiu su indeksu $j$;

$s k_{i}$ - konvertuojamą pažymį $a_{i}$ atitinkančių vertinimų skaičius; 
$s_{i j}$ - vertinimo skalės $A$ pažymio $a_{i}$ vertinimų skaičius, atitinkantis vertinimo skalės $B$ pažymị $b_{j}$;

$r s k_{r}$ - vertinimo skalès $A$ reitingą $r$ atitinkančiu vertinimų skaičius;

$c_{r j}^{i}$ - vertinimo skalès $A$ pažymio $a_{i}$, kurio reitingas $r$, vertinimų skaičius, atitinkantis vertinimo skalès $B$ pažymị $b_{j}$;

$F_{A}(x)$ - tikimybinio skirstinio, atitinkančio vertinimo skalès $A$ kontrolinès pažymių aibès duomenis, pasiskirstymo funkcija;

$F_{N}(x)$ - tikimybinio skirstinio, atitinkančio vertinimo skalès $A$ konvertuojamos teigiamu pažymių aibės duomenis, pasiskirstymo funkcija;

$Q_{N i}$ - tikimybinio skirstinio, atitinkančio vertinimo skalès $A$ konvertuojamos teigiamų pažymių aibės duomenis, $i$-tosios požymio reikšmès kvantilis;

$Q_{A i}$ - tikimybinio skirstinio, atitinkančio vertinimo skalès $A$ kontrolinės pažymių aibės duomenis, $i$-tosios požymio reikšmės kvantilis;

$Q_{B j}$ - tikimybinio skirstinio, atitinkančio vertinimo skalès $B$ kontrolinės pažymių aibès duomenis, $j$-tosios požymio reikšmės kvantilis.

\section{Santrumpos}

CMS - turinio valdymo sistema (angl. Content Management System);

DB - duomenų bazé;

DBVS - duomenų bazių valdymo sistema;

EAS - e. mokymosi rezultatu vertinimo sistema (angl. E-learning Assessment System);

ECTS - ị besimokantị asmenị orientuota kreditų kaupimo ir perkèlimo sistema, grindžiama aiškiais studijų siekiniais ir mokymosi procesu (ECTS naudotojo vadovas 2009);

ELS - e. mokymosi sistema (angl. E-learning System);

ES - Europos sajunga;

LCMS - mokymo turinio valdymo sistema (angl. Learning Content Management System);

LMS - mokymo valdymo sistema (angl. Learning Management System). 


\section{Turinys}

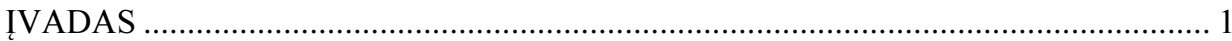

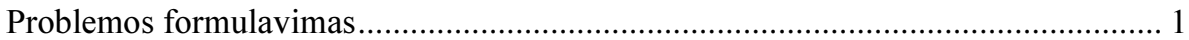

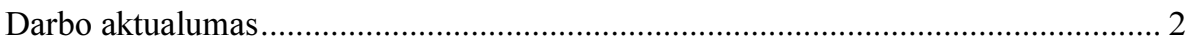

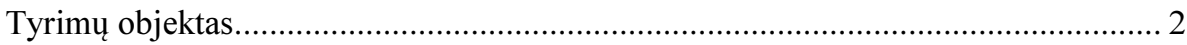

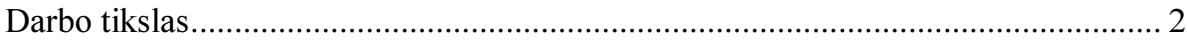

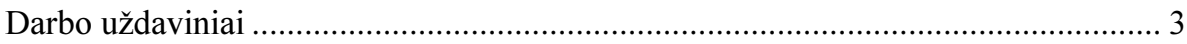

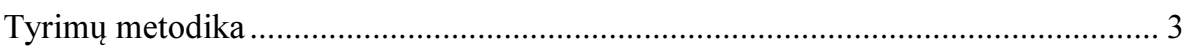

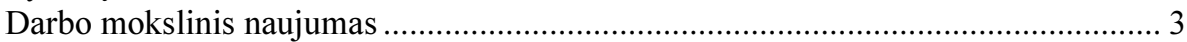

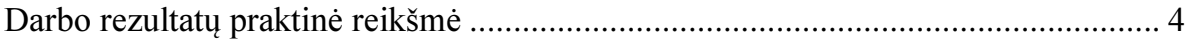

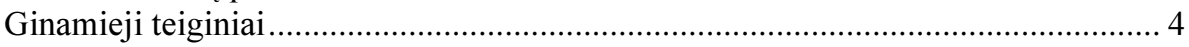

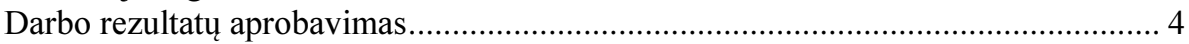

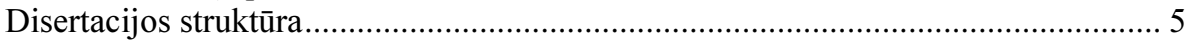

1. E. MOKYMOSI REZULTATŲ VERTINIMO TECHNOLOGIJŲ TYRIMŲ

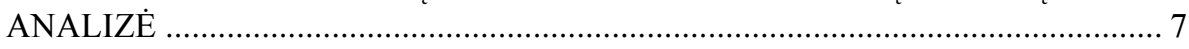

1.1. E. mokymosi rezultatų vertinimo technologijų tyrimai Lietuvoje........................ 7

1.2. E. mokymosi rezultatų vertinimo technologijų tyrimai užsienyje ...................... 11

1.3. Pirmojo skyriaus išvados ir disertacijos uždavinių formulavimas..................... 15

2. STUDIJŲ REZULTATŲ VERTINIMO MODELIŲ IR SISTEMŲ

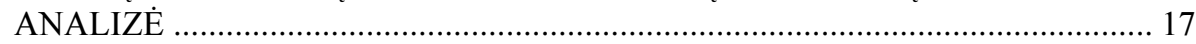

2.1. Studijų rezultatų vertinimo modeliai .................................................................. 17 
2.2. Studijų rezultatų vertinimo sistemų analizè

2.3. Pažymių konvertavimo metodikos parinkimas................................................... 44

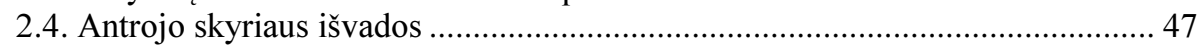

3. PAŽYMIŨ KONVERTAVIMO MODELIAI IR JUOS REALIZUOJANTYS

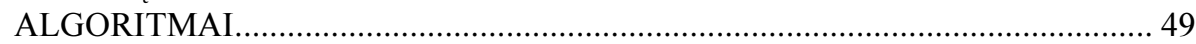

3.1. Dviparametris pažymių konvertavimo modelis .............................................. 50

3.2. Dviparametrị pažymių konvertavimo modelị realizuojantis algoritmas............ 53

3.3. Triparametris pažymių konvertavimo modelis ................................................ 56

3.4. Triparametrị pažymių konvertavimo modelį realizuojantis algoritmas............. 62

3.5. Pažymių konvertavimo algoritmų sudetingumo vertinimas .............................. 63

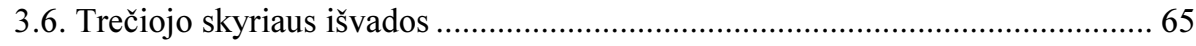

4. PAŽYMIŲ KONVERTAVIMO MODELIŲ EKSPERIMENTINIS TYRIMAS...... 67

4.1. Dviparametrio pažymių konvertavimo modelio eksperimentinio testavimo

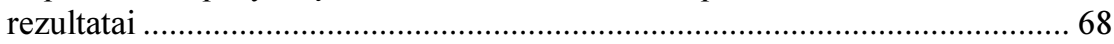

4.2. Triparametrio pažymių konvertavimo modelio eksperimentinio testavimo

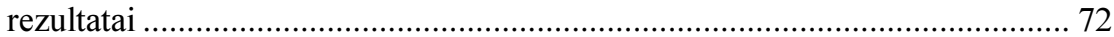

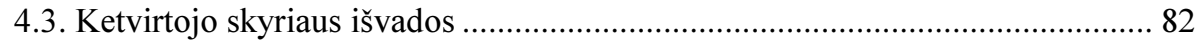

5. PAŽYMIŲ KONVERTAVIMO MODELIO INTEGRAVIMAS I

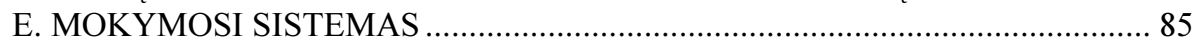

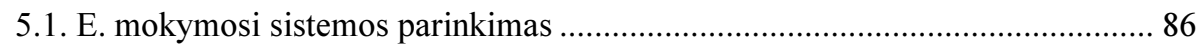

5.2. Pažymių konvertavimo modulio funkcionalumas e. mokymosi sistemoje......... 88

5.3. Pažymių konvertavimo modelio parinkimas .................................................... 90

5.4. Pažymių konvertavimo modelio integravimas ị Moodle sistemą ....................... 91

5.5. Pažymių konvertavimo modulio panaudojimas e. mokymosi procese ............. 101

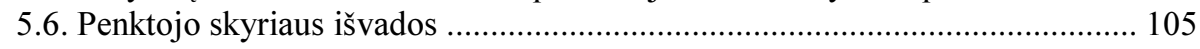

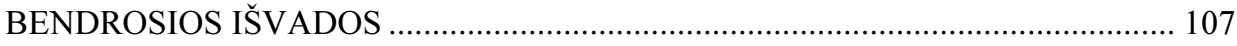

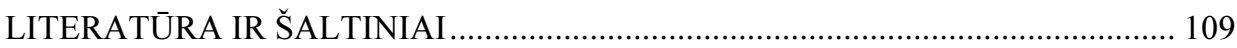

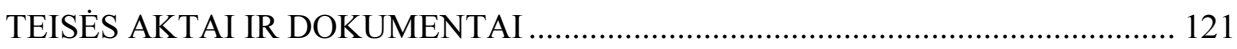

AUTORIAUS PUBLIKACIJŲ DISERTACIJOS TEMA SĄRAŠAS ........................ 125

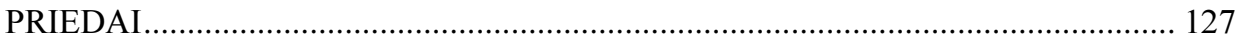

A priedas. Dviparametrio pažymių konvertavimo modelio testuojamų vertinimo skalių pažymių pasiskirstymas.................................................................. 127

B priedas. Triparametrio pažymių konvertavimo modelio konvertuojamų pažymių aibių duomenų pasiskirstymas .................................................................... 130 


\section{Contents}

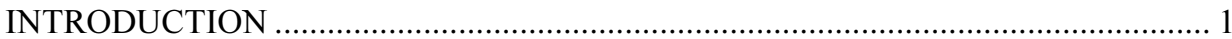

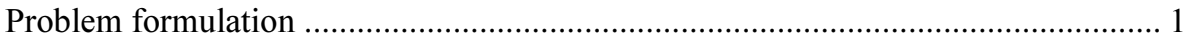

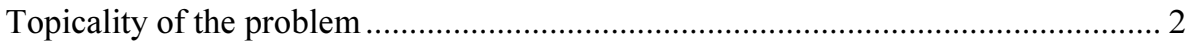

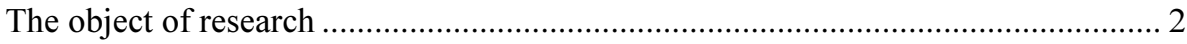

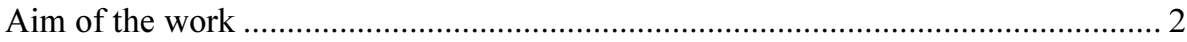

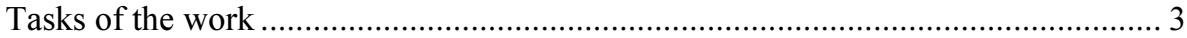

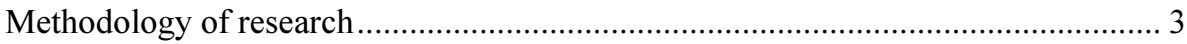

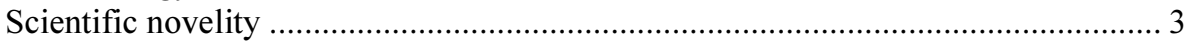

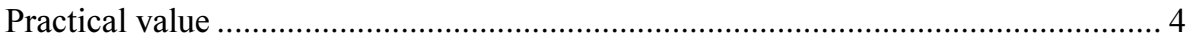

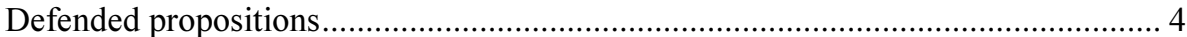

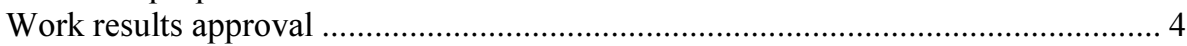

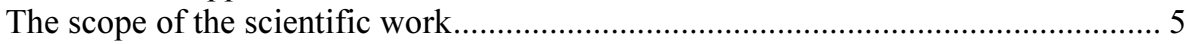

1. ANALYSIS OF THE RESEARCH ON THE ASSESSMENT TECHNOLOGIES OF

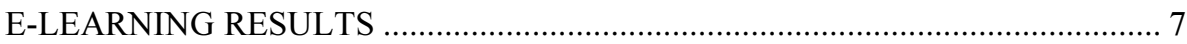

1.1. Research on the assessment technologies of e-learning results in Lithuania....... 7

1.2. Research on the assessment technologies of e-learning results abroad ............. 11

1.3. Conclusions of the first chapter and formulation the tasks of the dissertation .. 15

2. ANALYSIS OF THE GRADING SYSTEMS AND MODELS OF STUDY

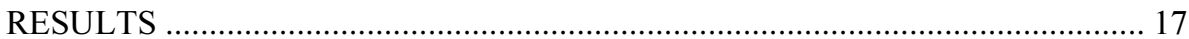

2.1. Assessment models of the study results ........................................................ 17 
2.2. Analysis of the grading systems of study results.............................................. 24

2.3. Selection of grade transfer methodology .......................................................... 44

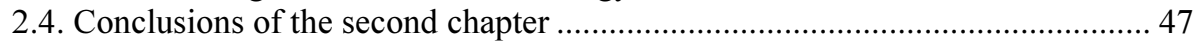

3. GRADE CONVERSION MODELS AND ALGORITHMS FOR THEIR

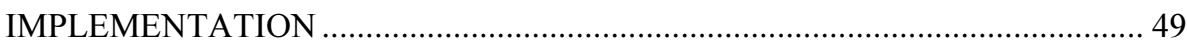

3.1. Two-parameter grade conversion model ....................................................... 50

3.2. Algorithm implementing the two-parameter grade conversion model .............. 53

3.3. Three-parameter grade conversion model ..................................................... 56

3.4. Algorithm implementing the three-parameter grade conversion model ............ 62

3.5. Evaluation of the grade conversion algorithm complexity ……........................ 63

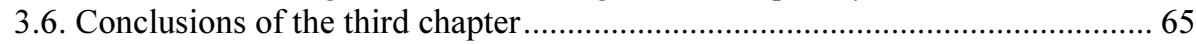

4. EXPERIMENTAL STUDY OF THE GRADE CONVERSION MODELS ............. 67

4.1. Results of the experimental testing of the two-parameter grade conversion

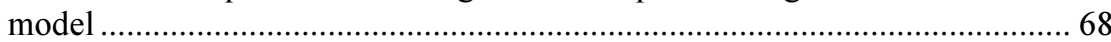

4.2. Results of the experimental testing of the three-parameter grade conversion

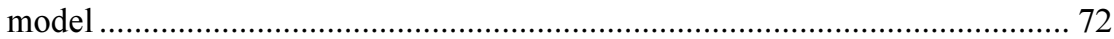

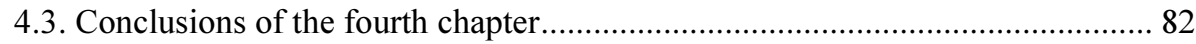

5. INTEGRATION OF THE GRADE CONVERSION MODEL INTO E-LEARNING

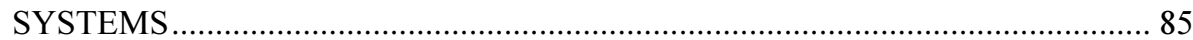

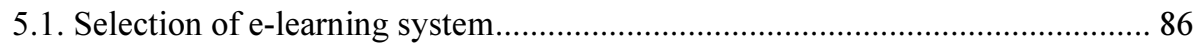

5.2. Funcionality of grade transfer module in e-learning system ............................. 88

5.3. Selection of the grade conversion model....................................................... 90

5.4. Integration of the grade conversion model into the Moodle system .................. 91

5.5. Grade conversion module uses in e-learning process ...................................... 101

5.6. Conclusions of the fifth chapter ................................................................. 105

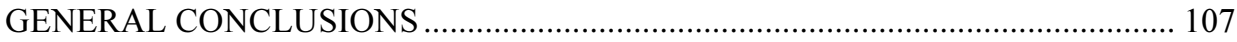

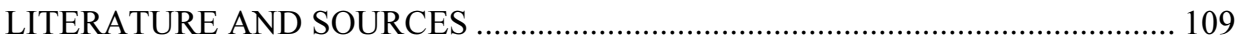

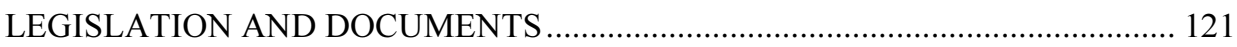

AUTHOR`S PUBLICATIONS ON THE TOPIC OF DISSERTATION ..................... 125

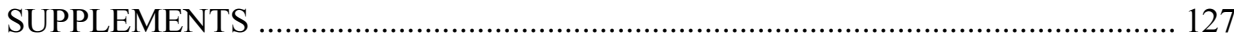

Supplement A. The grades distribution of grading scales, while conversion of grades is carried with two-parameter grade transfer model ..................................... 127

Supplement B. Distribution of convertible grades sets data, while conversion of grades is carried with three-parameter grade transfer model ......................... 130 


\section{Ivadas}

\section{Problemos formulavimas}

Spartūs pasaulio pokyčiai lemia ir aukštojo mokslo kaitą. Europos bei kitų pasaulio šalių aukštojo mokslo institucijoms jungiantis i bendrą Europos aukštojo mokslo erdvę, lyginamos ir derinamos skirtingos aukštojo mokslo sistemos, stiprinama studijų kokybè. Šiuo metu Bolonijos procesas jungia 47 šalis, iš kurių 27 priklauso Europos Sajungai ir 20 nèra Europos Sajungos šalys. Aukštojo mokslo globalizacija naikina nacionalines švietimo sienas, skatina vykdomų studijų programų internacionalizavimą.

Europos bendros aukštojo mokslo erdvès tobulinimo per ateinantị dešimtmetị prioritetai apibrèžti komunikate „Bolonijos procesas 2020 - Europos aukštojo mokslo erdvè naujajame dešimtmetyje“. Tarp jų: studijų prieinamumo visoms socialinėms grupèms didinimas, orientacija i studentu poreikius bei lūkesčius, studentų ir dėstytojų mobilumo skatinimas, tarptautinio atvirumo vystymas, mokymosi visą gyvenimą plètojimas.

E. mokymasis - tai priemone Bolonijos proceso nuostatoms igyvendinti. Tyrimais įrodyta, kad e. mokymasis suteikia studijoms patrauklumo, leidžia tobulinti studijų kokybę ne tik technologine, bet ir pedagogine prasme. E. mokymasis - tai piemonè igyvendinant virtualų studentų mobilumą. 
Pokyčiai aukštojo mokslo erdvèje kelia naujus reikalavimus e. mokymosi rezultatų vertinimo technologijoms. Internacionalizuojantis aukštajam mokslui, naująsias tendencijas turi atitikti ir e. mokymosi rezultatų vertinimo technologijos. Jos turi būti pritaikytos jungtiniams e. mokymosi kursams teikti, turi atitikti skirtingų šalių besimokančiujų poreikius.

Disertacijoje numatoma atlikti e. mokymosi rezultatų vertinimo technologijų tyrimus ir spręsti automatinio vertinimų konvertavimo iš vienos vertinimo skalès i kitą problemas. Sukurti vertinimų konvertavimo modelius, kurie leistų spręsti e. mokymosi rezultatų vertinimo technologijų internacionalizavimo, îvertinant studijų rezultatų vertinimo sistemų skirtumus, uždavinius.

\section{Darbo aktualumas}

Pokyčiai aukštojo mokslo erdvejje skatina e. mokymosi kaitą. Steigiami virtualūs universitetai, virtualūs studentų miesteliai, populiarèja jungtinės studijos, pradedamas igyvendinti virtualus studentu mobilumas. Sprendžiant aukštojo mokslo suderinamumo problemas, pasaulio aukštosiose mokyklose diegiama Europos kreditu kaupimo ir perkèlimo sistema (ECTS). Tačiau šiuolaikinès e. mokymosi rezultatų vertinimo technologijos neturi priemonių pažymiams iš vienos studijų rezultatų vertinimo skalès į kitą konvertuoti. Automatinis pažymių konvertavimas - tai aktuali ir neišspręsta mokslinè problema. Tai paskatino atlikti e. mokymosi rezultatų vertinimo technologijų tyrimą.

Perkeliant mokymosi procesą i virtualią erdvę, būtinas e. mokymosi rezultatų vertinimo technologijų tobulinimas. Tai skatina vykdyti mokslinius tyrimus e. mokymosi rezultatu vertinimo technologiju srityje, analizuoti e. mokymosi rezultatų vertinimo technologijų pritaikymo ịvairių šalių besimokantiesiems klausimus.

\section{Tyrimų objektas}

Darbo tyrimų objektas - pažymių automatinis konvertavimas iš vienos studijų rezultatų vertinimo skalès į kitą.

\section{Darbo tikslas}

Šio darbo pagrindinis tikslas - sukurti vertinimu automatinio konvertavimo iš vienos vertinimo skalès i kitą modelius. 


\section{Darbo uždaviniai}

Siekiant užsibrèžto tikslo sprendžiami šie uždaviniai:

1. Atlikti tyrimų e. mokymosi rezultatų vertinimo technologijų srityje analizę.

2. Išanalizuoti studijų rezultatų vertinimo modelius ir sistemas.

3. Sukurti vertinimų konvertavimo iš vienos vertinimo skalès i kitą modelius ir juos realizuojančius algoritmus.

4. Atlikti sukurtų vertinimų konvertavimo modelių eksperimentinį tyrimą.

5. Integruoti pažymių konvertavimo modelị ị e. mokymosi sistemą.

\section{Tyrimų metodika}

Literatūros analizè atlikta nagrinėjant tyrimus e. mokymosi rezultatų vertinimo technologijų srityje, analizuojant įvairių šalių studijų rezultatų vertinimo sistemas. Pažymių konvertavimo modeliams kurti buvo taikomas matematinio modeliavimo metodas. Sukurtiems modeliams testuoti taikytas eksperimentinis metodas, o rezultatams apibendrinti - vertinamasis tyrimo metodas.

\section{Darbo mokslinis naujumas}

E. mokymosi sistemos, e. mokymosi rezultatu vertinimo technologijos, jų taikymas studijų procese mokslinejje literatūroje nagrinèjama gana plačiai, tačiau nèra sprendžiamos šiandieninių vertinimo kaitos tendencijų inicijuojamos problemos. Sparčiai plintant „mokymosi be sienu“ idèjai, e. mokymosi rezultatų vertinimo technologijos turi būti internacionalizuojamos, sprendžiami ịvairių šalių vertinimo skalių suderinamumo klausimai.

Šiuolaikinèse e. mokymosi sistemose studentų mokymosi rezultatams vertinti gali būti taikomos ar kuriamos ịvairios institucijos poreikius atitinkančios studijų rezultatų vertinimo skalès. Tačiau dèl neišspręstų vertinimo skalių suderinamumo problemų, e. mokymosi kursų pritaikymas ịvairių šalių studentams išlieka problemiškas. Taigi e. mokymosi rezultatu vertinimo technologijos turi būti tobulinamos. Rengiant disertaciją buvo gauti šie informatikos inžinerijos mokslui nauji rezultatai:

1. Sukurti dviparametris ir triparametris pažymiu konvertavimo iš vienos vertinimo skalès į kitą modeliai ir juos realizuojantys algoritmai. 
2. Parinktas vertinimų konvertavimo modelis pažymiams e. mokymosi sistemose konvertuoti ir jis integruotas ị e. mokymosi sistemą.

\section{Darbo rezultatų praktinė reikšmė}

Sukurti vertinimų konvertavimo iš vienos vertinimo skalès i kitą modeliai. Parinktas e. mokymosi sistemoms tinkantis pažymių konvertavimo modelis ir jis integruotas ị Moodle sistemą.

\section{Ginamieji teiginiai}

1. Dviparametris pažymių konvertavimo modelis yra tinkamas pažymiams iš vienos vertinimo skalès ị kitą automatiškai konvertuoti.

2. Triparametris pažymių konvertavimo modelis yra tinkamas pažymiams iš vienos vertinimo skalès ị kitą automatiškai konvertuoti.

3. Integruojant pažymių konvertavimo funkciją i e. mokymosi sistemą, dviparametrio pažymių konvertavimo modelio algoritmo pagrindu turi būti kuriamas ir e. mokymosi sistemą integruojamas pažymių konvertavimo modulis.

\section{Darbo rezultatų aprobavimas}

Disertacijos tema yra paskelbta 12 mokslinių straipsnių: penki - recenzuojamuose mokslo žurnaluose; du - leidiniuose, įtrauktuose ị Mokslinès informacijos instituto konferencijų darbų sąrašą (ISI Proceedings); vienas - tarptautinès konferencijos medžiagoje; du - kitose respublikinių konferencijų medžiagose; du kituose recenzuojamuose leidiniuose.

Disertacijoje atliktų tyrimų rezultatai buvo paskelbti dvylikoje tarptautinių ir respublikinių mokslinių konferencijų:

- Respublikinejje konferencijoje „Informaciniu technologiju taikymas švietimo sistemoje 2009: E-studiju patirtis, aktualijos ir perspektyvos" 2010 m. Kaune.

- Respublikinèje konferencijoje „Lietuvos matematiku draugijos 49-oji konferencija“ $2009 \mathrm{~m}$. Vilniuje.

- Respublikinèje konferencijoje „Informacinès technologijos: teorija, praktika, inovacijos 2009“ 2009 m. Alytuje. 
- Respublikinejje konferencijoje „Informaciniu technologijų taikymas švietimo sistemoje 2010: E-studiju patirtis, aktualijos ir perspektyvos" 2011 $\mathrm{m}$. Kaune.

- Tarptautineje konferencijoje „E-Education: Science, Study \& Business“ $2010 \mathrm{~m}$. Vilniuje.

- Tarptautineje konferencijoje „Information and Software Technologies, IT 2010“2010 m. Kaune.

- Respublikineje konferencijoje „Informacinès technologijos: teorija, praktika, inovacijos 2010“ 2010 m. Alytuje.

- Respublikineje konferencijoje „Lietuvos matematiku draugijos 50-oji konferencija“ $2010 \mathrm{~m}$. Šiauliuose.

- Tarptautineje konferencijoje „The 2011 World Congress on Computer Science and Information Technology, WCSIT'11" 2011 m. Kaire Egipte.

- Tarptautineje konferencijoje „Information and Software Technologies, IT $2011^{\prime \prime} 2011 \mathrm{~m}$. Kaune.

- Respublikineje konferencijoje ,Lietuvos matematiku draugijos 51-oji konferencija“ $2011 \mathrm{~m}$. Vilniuje.

- Respublikineje konferencijoje „Kompiuterininku dienos 2011“ $2011 \mathrm{~m}$. Klaipèdoje.

\section{Disertacijos struktūra}

Darbą sudaro įvadas, penki skyriai ir rezultatų apibendrinimas. Darbo apimtis yra 126 puslapiai, neskaitant priedų, tekste panaudotos 35 numeruotos formulès, 53 paveikslai ir 35 lentelès. Rašant disertaciją buvo panaudoti 162 literatūros šaltiniai, 44 teisès aktai ir dokumentai.

Ivade pristatomas darbo aktualumas, darbo tikslai ir uždaviniai, mokslinis naujumas, naudoti moksliniai metodai, gauti darbo rezultatai, darbo aprobavimas.

Pirmajame skyriuje „E. mokymosi rezultaty vertinimo technologiju tyrimy analize " analizuojami e. mokymosi rezultatų vertinimo technologijų tyrimai, pagrindžiamas nagrinejjamos temos aktualumas, formuluojamos skyriaus išvados.

Antrajame skyriuje „Studiju rezultatu vertinimo modeliu ir sistemu analize“ “ nagrinëjamos įvairių šalių studijų rezultatų vertinimo sistemos, apžvelgiama ECTS vertinimo skalè, aptariamos šios vertinimo skalès taikymo problemos. Skyriaus pabaigoje parenkama pažymių konvertavimo iš vienos vertinimo skalès i kitą metodika ir formuluojamos skyriaus išvados. 
Trečiajame skyriuje „Pažymiu konvertavimo modeliai ir juos realizuojantys algoritmai " aprašomi sukurti pažymių konvertavimo modeliai ir juos realizuojantys algoritmai, ịvertinamas sukurtų algoritmų sudètingumas.

Ketvirtajame skyriuje „Pažymiu konvertavimo modeliu eksperimentinis tyrimas " pristatomas pažymių konvertavimo modelių eksperimentinis tyrimas ir pateikiami šio tyrimo rezultatai.

Penktajame skyriuje „Pažymiu konvertavimo modelio integravimas $i$ e. mokymosi sistemas " nagrinejjamas vertinimų konvertavimo modelio integravimas $\mathfrak{i}$ e. mokymosi sistemas, aptariami pažymių konvertavimo modelio integravimo ị Moodle sistemą klausimai. 


\section{1}

\section{E. mokymosi rezultatų vertinimo technologijų tyrimų analizè}

Skyriuje aptariama e. mokymosi tyrimų svarba, apžvelgiami tyrimai atlikti e. mokymosi, e. mokymosi rezultatų vertinimo technologijų srityje, aptariamos Lietuvos ir užsienio mokslininkų e. mokymosi, e. mokymosi rezultatų vertinimo technologijų tyrimų kryptys, analizuojamas nagrinejjamos problemos ištirtumo lygis, pagrindžiamas nagrinejjamos temos aktualumas.

\subsection{E. mokymosi rezultatų vertinimo technologijų tyrimai Lietuvoje}

E. mokymosi rezultatų vertinimo technologijų sąvoka šiame darbe naudojama, siekiant ịvardyti kompiuterines priemones, suteikiančias galimybę elektroniniu būdu vertinti studentų pasiektus mokymosi rezultatus. E. mokymosi rezultatų vertinimo technologijos apima e. mokymosi sistemas su integruotomis mokymosi pasiekimų vertinimo priemonėmis, įvairias e. mokymosi rezultatų vertinimo sistemas. 
Inovatyvių e. mokymosi ir e. mokymosi rezultatų vertinimo modelių kūrimas ir taikymas yra viena iš šiuo metu intensyviausiai plètojamų mokslo krypčių tiek pasaulyje, tiek Lietuvoje. Lietuvos Respublikos Vyriausybès patvirtintoje Aukštuju technologiju plètros programoje 2007-2013 akcentuojama elektroninių paslaugu plètra. Mokslinių tyrimų e. mokymosi ir nuotolinio mokymosi technologijų, metodologijos ir kokybès užtikrinimo srityse rèmimas ịtrauktas ir ị Lietuvos virtualaus universiteto (LVU) 2007-2012 metu programą. Lietuvos aukštojo mokslo tarptautiškumo skatinimo 2011-2012 metu programoje akcentuojama jungtinių studijų programų svarba, plètojant aukštojo mokslo tarptautiškumą. Todèl šiandien ypač svarbūs technologiniai tyrimai, vertinantys e. mokymosi rezultatų vertinimo technologijų pritaikymą jungtinèms studijų programoms teikti.

Moksliniai tyrimai e. mokymosi, e. mokymosi rezultatų vertinimo srityje vykdomi keliomis kryptimis. Nemažai reikšmingų tyrimų atlikta e. mokymosi metodologijos ir kokybès užtikrinimo srityse. A. Targamadzè, R. Petrauskienè (2008) analizavo nuotolinių studijų kokybę technologijų kaitos sąlygomis. Autoriai (2011) pristate IT ịrankių parinkimo kursui modelị ir atliko šio modelio tyrimą. R. Laužackas, M. Teresevičienè, A. Volungevičienè (2009) pateikè nuotolinio mokymosi turinio projektavimo modeli, grindžiamą nuotolinio mokymo(si) turinio kokybès vertinimo veiksniais. Vertinimo strategijos parengimas yra vienas iš autorių išskirtų nuotolinio mokymo(si) turinio projektavimo kokybės vertinimo veiksnių. D. Rutkauskienè, V. R. Mušankovienè, V. Krivickienė (2010) pristate LieDM tinklo nariams teikiamų paslaugu poreikio, kokybès tyrimo rezultatus. Sparčiai auga susidomejjimas antrosios kartos saityno (Web 2.0) technologijų taikymu studijose. 2009-2011 metais Vilniaus universiteto Matematikos ir informatikos institute buvo vykdomas projektas Mokymosi bendruomene antros kartos saityno technologiju mokymui, kurio tikslas buvo sukurti internetinę mokytojų bendruomenę, kurios narius domina Web 2.0 technologijų integravimas pamokose. V. Dagiené, E. Kurilovas (2011) pristate šio projekto rezultatus.

Intensyvūs tyrimai vyksta mokymosi objektu rengimo, panaudojimo, vertinimo srityje. N. Aukštikalnis, K. T. Baniulis (2006) nagrinejo testų-pratimų, kaip mokymosi objektų, rengimą testavimo sistemoje TestTool, analizavo į tikslą orientuoto vertinimo modelio realizavimo galimybes TestTool sistemoje. A. Slotkienè, K. T. Baniulis (2009) nagrinejjo aktyviuosius mokymosi objektus ir sukūré aktyviojo mokymosi objekto projektavimo metodą. I. Rupšienė (2009) analizavo naujosios kartos generatyvinius mokymosi objektus ir sukūre šiu objektų projektavimo metodus. R. Kubiliūnas, E. Bareiša (2009) sukūrè lanksčiai pritaikomų mokymosi objektų formavimo metodą, igalinantị elektroninès mokymosi medžiagos rengimo, redagavimo, atvaizdavimo skirtingais formatais, įkèlimo į mokymosi valdymo sistemas laiko sąnaudų sumažinimą, padidinantị 
mokymosi objektų pritaikymą mokymosi situacijai lankstumą. J. Kurilovas, V. Dagienè (2007) nagrinèjo lanksčios atvirosios e. mokymosi turinio ir paslaugų sistemos, skaitmeninès švietimo išteklių ir paslaugų bibliotekos kūrimo bendrajam lavinimui ir profesiniam mokymui mokslines problemas. Atlikti tyrimai svarbūs e. mokymosi rezultatams vertinti, keičiantys e. mokymosi rezultatų vertinimo veiklų konstravimo principus, didinantys e. mokymosi rezultatų vertinimo veiklų rengimo ir panaudojimo skirtingose situacijose veiksmingumą.

Sparčiai populiareja duomenu gavybos metodų taikymas e. mokymesi. Duomenu gavybos technologijų taikymo galimybes švietime jau 2003 metais analizavo R. Burbaite, S. Turskiene, G. Kulvietis. J. Mamčenko, I. Šileikienė (2006) aprašè programinių agentų, taikančių duomenų gavybos metodus ir prognozuojančių studentų veiklą, sukūrimą bei panaudojimą e. mokymesi. J. Mamčenko, I. Tumasoniené (2009) nagrinejjo netradicinių dokumentinių bazių duomenų paruošimą šiuolaikinèms duomenų gavybos technologijoms, pristatė dokumentinių bazių duomenų surinkimo, transformavimo bei filtravimo metodą, kuris realizuotas agentinèmis technologijomis. J. Mamčenko, I. Šileikienè, J. Lieponienè, R. Kulvietienè (2011) atliko elektroninių egzaminų duomenų analizę taikant duomenų gavybą ir pateikè rekomendacijas Vilniaus Gedimino technikos universitete naudojamai elektroninei egzaminavimo sistemai tobulinti. S. Preidys, L. Sakalauskas (2010) pristate duomenu gavybos metodais paremtą studentų veiklos stebėsenos sistemą, kuri palengvina kurso kuratoriaus darbą, suteikia daugiau informacijos apie studiju procesą, o reikalui esant pataria, kaip ši procesą tobulinti. Studentų veiklos stebėsenos sistema, analizuodama studentų veiklos duomenis, ne tik pateikia statistines diagramas, bet, panaudodama duomenų gavybos metodus, teikia ir tam tikrą informaciją: prognozuoja studentu prisijungimų kieki, analizuoja paskelbtus, nurodo kuratoriui sunkiausius bei lengviausius klausimus, tuo rekomenduodama pertvarkyti testą, klasterizuoja studentus pagal jų veiklą (Preidys et al. 2010). Atlikti tyrimai svarbūs e. mokymosi rezultatu vertinimo technologijoms tobulinti.

Plètojant naująą ugdymo koncepciją, igyvendinant i studijų rezultatus orientuotą mokymąsi, vis didesnę reikšmę igyja teorinių žinių pasitikrinimas praktikoje. Naująsias ugdymo kaitos tendencijas atliepia ir Lietuvoje vykdomi moksliniai tyrimai. E. Bagdonas, I. Patašienè, M. Patašius (2010) analizavo verslo įmonių veiklos pagrindinius ekonominius veiksnius, sukūrè ir eksperimentiškai patikrino verslo žaidimo architektūrą, kuria remiantis sukurtą ekonominių procesų imitacinio modeliavimo programinę įrangą būtų galima universaliai taikyti mokymui. E. Mačerauskas, R. Kulvietienè, A. Kozič (2010) pristate suprojektuotą elektronikos laboratoriją, valdomą nuotoliniu būdu. Šioje laboratorijoje studentai gali vykdyti laboratorinius eksperimentus, keisti eksperimento sąlygas, realiu laiku stebèti bandymus. Déstytojai gali teikti laboratorinius eksperimentus, keisti (koreguoti) laboratorinių eksperimentų užduotis, teikti naujus labora- 
torinius ekperimentus, gauti studentų atliktų laboratorinių eksperimentų rezultatus vertinimui (Mačerauskas et al. 2010). A. Bielskis, O. Ramašauskas, G. Stabingis (2005) pristatė Klaipėdos universiteto eksperimentinès e. laboratorijos projektą. Ši sistema leidžia nuotoliniu būdu besimokantiems asmenims pagilinti programavimo ir mechatronikos igūdžius, atlikti laboratorinius darbus.

Mokymo procese svarbus ne tik teorinių žinių pateikimas, bet ir praktinių igūdžiu, atitinkančių esamus darbo rinkos poreikius, suformavimas. Todèl pasiektų mokymosi rezultatų vertinimas neturi apsiriboti vien teorinių žinių tikrinimu, jis neišvengiamai turi apimti ir praktinių igūdžių vertinimą. Visapusiškam studentų žinių ir igūdžių tikrinimui T. Ligutis, S. Masiulevičius (2007) pristatė suprojektuotą praktinių igūdžių tikrinimo sistemą, kurioje žinių tikrinimas atliekamas užkraunant tikrinamos programinès įrangos darbo aplinką, kurioje besimokantysis turi atlikti realius veiksmus užduočiai atlikti. Testavimo sistemas analizavo E. Telešius ir R. Danielienè. Autoriai (2009) pateikè siūlymus ECDL testavimo sistemai tobulinti. Kad testavimo sistema tiksliau ịvertintų besimokančiujų žinias, autoriai rekomendavo tobulinti testų generavimą taikant adaptyvų testavimą ir užduočių atsako teoriją (Item Response Theory), pristate naują klausimų generavimo algoritmą, besiremianti klausimo sunkumo ir profesijos kriterijais (Telešius et al. 2009). R. Danielienè, E. Telešius (2011), remdamiesi ECDL testavimo sistemos statistika, nagrinejo, kokie nuo testuotojo priklausantys parametrai gali tureti įtakos testo rezultatams, pateikè siūlymų naudoti statistinius duomenis nustatant pradini testuojamojo igūdžių lygị. Praktinių programavimo igūdžių, kuriuos lemia gebejjimas logiškai mąstyti ir pritaikyti igytas žinias sprendžiant ịvairius uždavinius, kontrolei universalių testavimo sistemų panaudojimo galimybés yra labai ribotos, testai su pateikiamais galimų atsakymų rinkiniais tinka sąvokų supratimo, bet netinka loginio ir analitinio mąstymo igūdžių kontrolei, todèl V. Barzdaitis, A. Mickus, A. Vidžiūnas (2004) aprašè programavimo igūdžių testavimo sistemos konstravimo principus, pristate programavimo ịgūdžių testavimo sistemos modelị, kurị nesunku pritaikyti ịvairioms programavimo kalboms, keičiant testavimo sistemoje įkomponuotą kompiliatorių.

E. mokymosi aplinkų pritaikymą studentams pagal jų turimas žinias, gebėjimus, siekiamus tikslus analizavo V. Lukauskas, A. Bielskis (2005). Autoriai nagrinejjo adaptyviosios e. mokymosi aplinkos intelektualiojo komponento kūrimo principus, naudojant Kohoneno savitvarkio žemèlapio (SOM) neuroninius tinklus. J. Dzikienè (2010) analizavo agento mokymosi procesą, apimantị aplinkos modelio sudarymo, tikslo modelio sudarymo, veiksmų sekų planavimo ir veiksmų pasekmių prognozavimo algoritmus. Autore sukūre ir realizavo mokymo algoritmus, naujoviškai konstruojančius ir panaudojančius agento žinias, siekiant padidinti agento efektyvumą. D. Dzemydienè, L. Tankelevičienè (2008) nagrinèjo ontologijų taikymą e. mokymesi. Autorès pasiūlè konkrečius sprendi- 
mus, kaip turint dalykinès srities ontologiją realizuoti patogesnę e. mokymosi sistemos navigacinę sistemą, bei patariančią sistemą. D. Dzemydienė, L. Tankelevičienė (2009) analizavo e. mokymosi sistemos architektūros išplètimo galimybes, siekiant sukurti tinkamą kompiuterizuotą bendradarbiavimo aplinką, lanksčiai prisitaikančią prie kintančių vartotojo poreikių studijų procese. Atlikti tyrimai svarbūs projektuojant studentams pritaikytas e. mokymosi rezultatų vertinimo sistemas.

E. mokymosi sistemos pritaikomos skirtingoms kultūrinėms, kalbinėms, edukacinèms terpèms internacionalizuojant ir lokalizuojant e. mokymosi sistemas. Šiame darbe e. mokymosi sistemų internacionalizavimo terminas naudojamas įvardinant e. mokymosi sistemos pritaikymą skirtingų šalių, studijų rezultatų vertinimo sistemų studentams. Lietuvoje programinès įrangos lokalizavimo problemas tyré V. Dagiené, G. Grigas, T. Jevsikova (2010). T. Jevsikova (2009) pateikè išsamią lokalizavimo darbų analizę ir pasiūlè metodą lokalizavimo sąnaudoms mažinti bei kokybei gerinti. E. mokymosi sistemų, e. mokymosi rezultatų vertinimo technologijų internacionalizavimo klausimai nèra plačiai nagrinèjami Lietuvos tyrejuc darbuose. E. Kurilovas (2007) parengè e. mokymosi aplinkų techninio vertinimo kriterijus, ị kuriuos įtraukè internacionalizavimo ir lokalizavimo galimybių vertinimą. Remdamiesi parengtais techninio vertinimo kriterijais E. Kurilovas, V Dagienè (2010) lygino tris atvirojo kodo sistemas: Moodle, ATutor, Ilias. Autorių atliktų tyrimų rezultatai rodo, kad Moodle sistema lyginant su ATutor ir Ilias sistemomis yra lydere internacionalizavimo ir lokalizavimo srityje. R. Laucius (2007) analizavo kompiliatorių internacionalizavimo problemas. Autorius sukūré metodą kompiliatorių internacionalizuotumo lygiui ịvertinti ir pasiūlè kompiliatoriu internacionalizavimo metodą. Apibendrinat Lietuvoje vykdomus e. mokymosi srities tyrimus, galime pastebèti, kad e. mokymosi sistemų, e. mokymosi rezultatų vertinimo technologijų pritaikymas skirtingoms studijų rezultatų vertinimo sistemoms nèra tiriamas. Todèl analizuojama tema yra aktuali ir atitinka šiandienos poreikius.

\subsection{E. mokymosi rezultatų vertinimo technologijų tyrimai užsienyje}

Pasaulyje kaip Lietuvoje, vykdomas platus tyrimų spektras e. mokymosi, e. mokymosi rezultatų vertinimo technologijų srityje. 2006 metais žymus anglų nuotolinio mokymosi tyrinetojas T. Bates atliko e. mokymosi srityje vykdomų tyrimų analizę. Jo tyrimas parode, kad 10 proc. e. mokymosi srities tyrimų sudaro strateginiai, 30 proc. e. mokymosi metodologiniai ir net 60 proc. ịvairūs e. mokymosi technologiju tyrimai. T. Bates e. mokymosi strateginiams tyrimams priskyré tarptautinius, regioninius, nacionalinius tyrimus, inicijuojančius e. mokymosi 
politikos ir strategijos pokyčius, apibrèžiančius nacionalinius kokybės standartus ir ivairius kitus statistinius tyrimus. Metodologiniams e. mokymosi tyrimams autorius priskyrè e. mokymosi kursų projektavimo, kokybès užtikrinimo, e. mokymosi ir e. mokymosi rezultatų vertinimo gerosios patirties sklaidos ir kitus su e. mokymosi veikla susijusius tyrimus. Technologiniu tyrimu grupei T. Bates priskyre mokymosi objektų projektavimo, e. mokymosi ir e. mokymosi rezultatu vertinimo sistemų kūrimo, diegimo, tobulinimo, pritaikymo įvairioms studentų grupèms ir kitus tyrimus, susijusius su e. mokymuisi skirtų technologijų kūrimu ir tobulinimu.

Daug reikšmingų tyrimų atlikta e. mokymosi turinio projektavimo srityje. Sparčiai populiarejant e. mokymuisi, ịvairių šalių mokslininkai pradejjo ieškoti mokymosi turinio pateikimo būdų, kurie padètų efektyviau išmokti mokymosi medžiagą, skatintų studentų aktyvumą, kūrybiškumą, leistų lanksčiai taikyti medžiagą ịvairiems mokymo metodams ir mokymosi scenarijams, tai sąlygojo mokymosi objektų atsiradimą. T. Bates mokymosi objektų tyrimus įvardijo kaip vieną iš populiariausių Europos mokslinių tyrimų sričių. Europos šalyse įgyvendinamos įvairios mokymosi objektų mainų iniciatyvos. Pagrindinè iniciatyva yra Europos mokyklų tinklo (European Schoolnet, EUN) koordinuojama įvairių šalių mokymosi išteklių mainų (Learning Resource Exchange) iniciatyva, finansuojama pagal įvairius Europos Komisijos ir šaliu švietimo ministerijų projektus (CELEBRATE, CALIBRATE, MELT, ASPECT) (Dagienè et al. 2008).

Duomenu gavybos technologijų taikymas e. mokymosi problemoms spręsti sparčiai populiarejja (Castrol et al. 2007). İvairių šalių mokslininkai analizuoja e. mokymosi sistemose sukauptus mokymosi ir vertinimo duomenis, taikydami duomenu gavybos metodus. Ispanai L. Vincent, X. Gumara (2009) grupavo studentus pagal igytas kompetencijas. Taivano mokslininkai F. J. Liu, B. J. Shih skirste studentus i grupes pagal mokymosi stilių, naudodami duomenu gavybos metodus. Prancūzų mokslininkai A. Merceron, K. Yacef (2005) pristatè atliktą tyrimą, kuriame duomenu gavybos metodais analizavo studentų veiklos ir galutinių rezultatų priklausomybes. Indų mokslininkai V. Namdeo, A. Singh, D. Singh, R. C. Jain (2010) taike ivvairius klasifikavimo algoritmus, tirdami pasirinkto mokymosi būdo ir gautu įvertinimų priklausomybes. Ispanai M. Delgado Calvo-Floresa, W. Fajardo Contrerasa, E. L. Gibaja Galindob, R. Perez-Pereza (2006) prognozavo studentų įvertinimus, pasitelkę neuroninius tinklus. Kinų mokslininkai W. Wang, J. Weng, J. Su, S. Tseng (2006) sukūré SCORM standartą atitinkančių e. mokymosi kursų pritaikymo pagal studento žinias ir gebéjimus algoritmą, kuris remiasi besimokančiojo portfolio duomenu analize, naudojant duomenų gavybos metodus. E. mokymosi aplinkos adaptyvaus pritaikymo studentui problemas naudojant duomenų gavybos metodus nagrinëjo ir Tuniso mokslininkai M. K. Khribi, M. Jemni, O. Nasraoui (2009). 
Pasaulio mokslininkai nuolat ieško naujų būdų studentų igytiems studijų rezultatams tikrinti ir įvertinti. Pasaulio mokslininkai sukūre ịvairių adaptyvaus testavimo modeliu, suprojektavo ir realizavo adaptyvias testavimo sistemas. Ispanų mokslininkai A. Hatzigaidas, A. Papastergiou, G. Tryfon, D. Maritsa, P. Galanidis (2003) pristate adaptyvią testavimo sistemą SIETTE. Graikijos mokslininkai M. Grigoriadou, K. Papanikolaou, H. Kornilakis, G. Magoulas (2002) sukūrè intelektualią mokymosi sistemą INSPIRE, kurioje studentų igytiems studijų rezultatams tikrinti naudojamas adaptyvus testavimo būdas. Jungtinejje Karalysteje sukurta adaptyvi testavimo sistema SKATE. Japonų mokslininkas S. Imai (2008) pristate Japonijoje sukurtą adaptyvią testavimo sistemą, skirtą japonų kalbos žinioms ir igūdžiams tikrinti. Adaptyvias testavimo technologijas analizavo Azijos mokslininkai A. S. Arefin, S. Mahmud, M. Khan (2005), adaptyvaus testavimo modelius pristate $\mathrm{M}$. Al-A'ali (2007). Bulgarijos mokslininkai E. Kovatcheva, R. Nikolov (2009) pateikè adaptyvios e. mokymosi sistemos modeli, kurioje vertinimo grižtamosios informacijos pagrindu studentui adaptyviai parenkamas mokymosi turinys. Suprojektuotoje sistemoje sąryšiai tarp mokymuisi ir vertinimui skirtų objektų palaikomi naudojant bendrus metaduomenis, sukurti programiniai agentai koordinuoja mokymosi procesą.

E. mokymosi standartu rengimas ir diegimas yra aktuali ir svarbi e. mokymosi mokslinių tyrimų sritis. Elektroninio mokymosi standartus rengia įvairios organizacijos. Elektroninio mokymosi standartizavimo srityje dirba Elektros ir elektroninès inžinerijos mokymosi technologijų standartų komitetas (Learning Technology Standarts Committee of the Institute of Electrical and Electronics Engineeres - IEEE LTSC), Europos nuotolinio mokymosi kūrimo ir skelbimo tinklų sajunga (Alliance of Remote Instructional Authoring and Distribution Networks for Europe - ARIADNE), tarptautinis mokymosi konsorciumas (IMS Global Learning Consortium), aviacijos industrijos kompiuterinio mokymo komitetas (The Aviation Industry CBT (Computer-Based Training) Committee $A I C C$ ), e. mokymosi technologijų standartų kūrimo organizacija ADL (Advanced Distribute Learning). Sukurti e. mokymosi standartai apima turinio metaduomenų, turinio pakavimo, turinio eiliškumo nustatymo, klausimų ir testų suderinamumo, studentų profilių ir darbo aplinkos apibrěžimo sritis (Devedžic et al. 2007). Standartai padeda užtikrinti e. mokymosi ir e. mokymosi rezultatų vertinimo sistemų: sąveikumą (Interoperability), daugkartinị panaudojimą (Reusability), valdomumą (Manageability), prieinamumą (Accessibility), ilgaamžiškumą (Durability) (Khaskheli 2004). İvairių šalių mokslininkai analizuoja e. mokymosi ir e. mokymosi rezultatų vertinimo sistemų standartizavimo problemas, projektuoja lanksčias, standartizuotas e. mokymosi ir e. mokymosi rezultatų vertinimo sistemas. E. mokymosi standartų ịvairove ịneša nemažai problemų ir iššūkių e. mokymosi ir e. mokymosi rezultatų vertinimo sistemų projektuotojams (Al-Smadi et al. 2009). Austrijos mokslininkai M. Al-Smadi, Ch. Guetl, D. 
Helic (2009) analizavo standartizuotų e. mokymosi rezultatų vertinimo sistemų projektavimo problemas, pateikè lanksčios e. mokymosi rezultatų vertinimo sistemos konceptualų modelį. Autoriai išskyrè du lanksčių e. mokymosi rezultatų vertinimo sistemu standartizavimo lygmenis - išorini ir vidinị. Vidiniam e. mokymosi rezultatų vertinimo sistemų standartizavimo lygmeniui autoriai priskyrè reikalavimus e. mokymosi rezultatu vertinimo sistemos komponentus aprašančius standartus ir specifikacijas: klausimų ir testų suderinamumą (IMS QTI), su testais susijusių mokymosi objektų metaduomenų aprašymą (IEEE LOM), besimokančiuju profilių ir darbo aplinkos apibrèžimą (IMS LIP, PAPI Learner). M. Al-Smadi, Ch. Guetl, D. Helic (2009) išoriniam standartizavimo lygmeniui priskyré standartus ir specifikacijas, apibréžiančias e. mokymosi rezultatų vertinimo sistemos komunikavimo su išorinemis sistemomis bei sistemos naudotojais reikalavimus. Egipto mokslininkai M. H. Zedan, H. A. Hassan, S. R. El-Beltagy, A. A. Rafea (2011) analizavo IMS QTI standarto praplètimo galimybes, kurios užtikrintų mokymosi tikslams skirtų testų rengimą. Pasak autorių, rengiant mokymosi tikslams skirtus testus būtinas testo klausimų aprašymas su mokymosi rezultatais, susietais metaduomenimis, sunkumo lygmenimi, tikrinama sąvoka ir tiksline grupe. Testo klausimų aprašymo metaduomenimis problemas analizavo Liuksemburgo mokslininkai - S. Sarre, M. Foulonneau (2010).

Nemaža reikšmingų darbų atlikta e. mokymosi rezultatų vertinimo sistemų projektavimo srityje. Austrijos mokslininkai M. Al-Smadi, Ch. Gutl, R. Kannan (2010) pristate lanksčios modulinès e. mokymosi rezultatų vertinimo sistemos modeli. Projektuojamai sistemai autoriai parinko i paslaugas orientuotą architektūrą (Service Oriented Architecture). E. mokymosi rezultatų vertinimo įrankių projektavimą i paslaugas orientuotos architektūros principu analizavo ir Didžiosios Britanijos mokslininkai W. M Davies ir H. C. Davis (2005). Bulgarijos mokslininkai M. Petrov, A. A. Petrova (2009) pristate e. mokymosi rezultatu vertinimo sistemą, kurioje realizuotos ne tik tradicinès vertinimo formos - egzaminavimas, testavimas, bet ir nauja studiju rezultatų vertinimo forma - skaitmeninis aplankas (e. portfolio). Pasak Didžiosios Britanijos mokslininkų T. Dube, M. Ma, studijų rezultatų vertinimas turi atitikti studento mokymosi stilių, o iškeltus vertinimo tikslus galima pasiekti tik vertinamo studento mokymosi stilių atitinkančiomis kontrolinėmis užduotimis. T. Dube, M. Ma (2010) pristatė lanksčios e. mokymosi rezultatų vertinimo sistemos, parenkančios vertinamas užduotis pagal mokymosi stilių, modelị.

Aukštojo mokslo institucijoms integruojantis i bendrą Europos švietimo erdvę, vis aktualesni tampa aukštojo mokslo institucijų internacionalizavimo klausimai. Europos universitetų mokslininkai vis dažniau jungiasi bendriems moksliniams tyrimams vykdyti. Europos universitetų mokslininkų vykdomu Tuning projektu siekiama identifikuoti svarbiausias kompetencijas, kurios turètu būti ugdomos ES aukštosiose mokyklose, rengiančiose specialistus darbo rinkai, 
ir suderinti visas svarbiausias aukštojo mokslo veiklos sistemas užtikrinant laisvą žmoniu judejjimą ir akademinị mobilumą. Estijos mokslininkè G. Mihhailova (2006) e. mokymąsi ịvardija kaip aukštojo mokslo internacionalizavimo strategiją. Igyvendinant internacionalizavimo strategijos nuostatas, e. mokymosi rezultatų vertinimo technologijas būtina pritaikyti skirtingų šalių, institucijų studentams. Atlikta literatūros analizè parodè, kad e. mokymosi rezultatų vertinimo technologijų internacionalizavimo klausimai aktuali ir dar neištirta mokslinių tyrimų sritis. Ivairių šalių mokslininkai analizuoja e. mokymosi sistemų pritaikymą skirtingoms kultūrinėms ir kalbinėms terpèms problemas, tačiau silpnai tiriami šiandienines aukštojo mokslo kaitos tendencijas atitinkantys internacionalizavimo klausimai, nèra nagrinejjami e. mokymosi rezultatų vertinimo technologijų internacionalizavimo, ịvertinant studijų rezultatų vertinimo sistemų skirtumus, aspektai. E. mokymosi rezultatu vertinimo technologiju pritaikymas jungtiniams e. mokymosi kursams teikti - svarbi ir dar neištirta mokslinių tyrimų sritis.

\subsection{Pirmojo skyriaus išvados ir disertacijos uždavinių formulavimas}

1. Atlikta Lietuvos mokslininkų darbų analizè parodè, kad Lietuvoje moksliniai tyrimai e. mokymosi, e. mokymosi rezultatu vertinimo srityje vykdomi e. mokymosi metodologijos ir kokybės užtikrinimo, informacinių technologijų taikymo, duomenų gavybos technologijų naudojimo, e. mokymosi rezultatų vertinimo sistemų projektavimo, e. mokymosi sistemų tobulinimo kryptimis.

2. Pasaulyje vykdomas platus tyrimų spektras e. mokymosi srityje. T. Bates šiuos tyrimus skirsto i strateginius, metodologinius ir technologinius. Svarūs pasaulio mokslininkų technologiniai tyrimai e. mokymosi turinio projektavimo, duomenų gavybos technologijų taikymo, e. mokymosi rezultatų vertinimo sistemų projektavimo, standartizavimo srityse.

3. Atlikta mokslinių darbų analizè parodé, kad tiek Lietuvoje, tiek pasaulyje e. mokymosi rezultatų vertinimo technologijų pritaikymas ịvairių šalių studentams dar per mažai analizuota ir dar neištirta mokslinių tyrimų sritis. Ši analizè pagrindžia nagrinejjamos temos aktualumą ir atliekamo tyrimo būtinumą.

Darbo tikslui pasiekti suformuluoti šie uždaviniai: išanalizuoti studijų rezultatų vertinimo modelius ir sistemas; sukurti vertinimų konvertavimo iš vienos vertinimo skalès i kitą modelius ir juos realizuojančius algoritmus; atlikti sukurtų vertinimų konvertavimo modelių eksperimentinį tyrimą; integruoti pažymių konvertavimo modeli i i e. mokymosi sistemą. 



\section{Studijų rezultatų vertinimo modeliụ ir sistemų analizè}

Skyriuje apžvelgiami įvairūs studijų rezultatų vertinimo modeliai, analizuojamos ivairių šalių studijų rezultatų vertinimo sistemos, aptariamos ịvairiose šalyse taikomų studijų rezultatų vertinimo sistemų palyginamumo problemos, išskiriami kriterijai, kuriais remiantis vertinimus būtu galima konvertuoti iš vienos studijų rezultatų vertinimo skalès į kitą, pasirenkama pažymių konvertavimo metodika.

\subsection{Studijų rezultatų vertinimo modeliai}

Studijų rezultatų vertinimas - svarbi studijų proceso dalis. Rusijos psichologų ir sociologu atliktas tyrimas parodè, kad vertinant dèstytoją, kaip profesionalą, svarbus kriterijus yra ne tik dėstomo dalyko išmanymas, bet ir gebejjimas vertinti studentų pasiekimus (Askerov et al. 2010). Aukštosiose mokyklose taikomi įvairūs mokymosi pasiekimų lygio nustatymo būdai - vertinimo modeliai. T. Bulajeva skiria normini, kriterinị ir standartais grịstą vertinimo modelius (Bulajeva 2007). Pasak J. Biggs (1999), vertinimo modelio pasirinkimas priklauso nuo 
švietimo sistemos filosofijos. Istoriškai norminis vertinimas atsirado anksčiau nei kriterinis vertinimas (Biggs 1999).

Taikant norminị arba normomis grịstą vertinimo modelį, vertinamasis ir jo vertinimo rezultatai lyginami su kitų tos pačios grupés studentų rezultatais. Pasak G. Petty (2006), norminis vertinimas yra tada, kai kandidatai lyginami vienas su kitu, o laimi geriausieji. Šiuo vertinimu, lyginant studentų vertinimo rezultatus, galima studentus sugrupuoti, suskirstyti pagal pasiekimu lygi ir nustatyti, ar jų pasiekimai atitinka nustatytas normas. Śis vertinimas dažniausiai atliekamas taikant testavimo metodą. N. L. Gage ir D. C. Berliner (1994), aptardami normini vertinimą, išskiria interpretavimo sąvoką. Autoriu teigimu, normomis pagrịstuose testuose testo atlikimas yra interpretuojamas, lyginant su kitu individų atliktais testais. Autorių teigimu, toks vertinimas gali būti vienas iš būdų paskatinti žemesnio pažangumo studentą labiau stengtis draugų akivaizdoje.

Tuo tarpu kriterinis vertinimas, pasak M. Teresevičienès ir G. Gedvilienès (2000), yra pagrịstas pažymio priklausomybe nuo tam tikro absoliutaus kokybės standarto. Kaip pastebi autorès, toks vertinimas yra tinkamas vertinant bendradarbiaujančias grupes. Pasak T. Bulajevos, kriterijais grịsto vertinimo esmé ta, kad dar iki vertinimo pradžios vertintojas formuluoja vertinimo kriterijus, ir vèliau, kai atliekamas vertinimas, vertinamojo mokymosi rezultatai lyginami su iš anksto apibrezžtais vertinimo kriterijais (Bulajeva 2007).

Norminis vertinimas skiriasi nuo kriterinio vertinimo pagal tikslus ir pagrindus. Jo tikslas - sugrupuoti studentų veiklos rezultatus ị hierarchinę sistemą ir ja remiantis nustatyti studento reitingą. Tokia sistema naudinga organizuojant konkursus, kai reikia išrinkti geriausius. Norminiame vertinime kriterijai nevaidina esminio vaidmens. Svarbiausia yra vertinimo norma. Vertinant studentus, vertinimo norma gali būti studentų padarytų klaidų skaičius. Kriterinis vertinimas pagrịstas rezultatų atitiktimi kriterijams. Pagal kriterinį vertinimą studentai yra ne lyginami vieni su kitais, kaip norminio vertinimo atveju, bet vertinami pagal atitiktị vertinimo kriterijams. Be to, kriterinis vertinimas yra ne toks šališkas.

Taikant kriterinį vertinimą, visi studentai turi galimybę gauti gerą įvertinimą, jei jų pasiekimai atitinka iš anksto apibrež̌tus kriterijus. T. Bulajeva akcentuoja, kad kriterinis vertinimas teikia daugiau informacijos apie studentų pažangą, padeda išryškinti spragas ir mokymosi problemas.

Taikant normini vertinimo modeli, vertinama taip, kad dauguma studentu gautų vidutinius pažymius, dalis - gerus, o dalis gali gauti ir blogą ịvertinimą, t. y. pagal normalinę pasiskirstymo kreivę (2.1. pav.). T. Bulajeva akcentuoja, kad pagrindinis norminio vertinimo trūkumas yra tas, kad jis riboja galimybes didesniam studentų skaičiui gauti aukštus įvertinimus (Bulajeva 2007). 


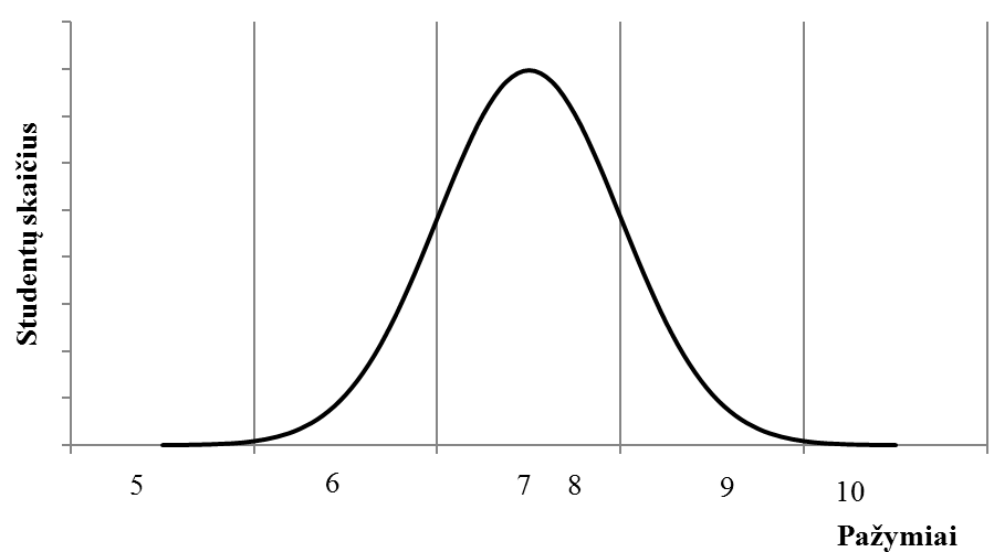

2.1 pav. Normalinė pažymių pasiskirstymo kreivė

Fig. 2.1. Normal grade distribution curve

Standartais grịstas vertinimo modelis kilo iš kriterijais grịsto vertinimo modelio. T. Bulajeva teigia, kad švietimo srityje dažniausiai taikomi šie standartizavimo būdai: mokymosi, studijų rezultatų standartizavimas ir studijų proceso pabaigoje igyjamų kvalifikacijų standartizavimas. Pirmojo rezultatų standartizavimo būdo pavyzdys yra visų mokyklinio ugdymo pakopų - pradinès, pagrindinès, vidurinès - ir visų mokomujų dalykų išsilavinimo standartai. Jie pakeitè ilgai egzistavusius ugdymo turinio standartus. Aukštajame moksle aukštojo mokslo standartizavimo link žengtas žingsnis yra posūkis ị kompetencijomis grịstą ugdymą, t. y. tokị ugdymą, kai standartizuojami studentų mokymosi ar studijų baigties rezultatai (Bulajeva 2007).

Pagal vertinimo tikslus skiriami šie pagrindiniai vertinimo tipai: formuojamasis vertinimas, apibendrinamasis vertinimas, kaupiamasis vertinimas (Bulajeva 2007). Formuojamojo vertinimo tikslas yra teikti studentui išsamią vertinimo grižžamają informaciją, padeti jam mokytis (Hillesheim 1998). Tyrimais įrodyta, kad negali būti veiklos tobulinimo, neturint grižtamosios informacijos, nežinant rezultatų. Savo veiklos rezultatų žinojimas leidžia suvokti trūkumus, aiškintis jų priežastis, jas šalinti (Čiužas et al. 2008). A. Bischoff pabrèžia, kad studentams būtinas pastovus grį̌ztamasis ryšys, informuojantis besimokantijj apie daromą pažangą, pasiektus rezultatus (Bischoff 2000). Formuojamuoju vertinimu teikiama grị̌tamoji informacija turi išryškinti studento stipriąsias ir silpnąsias puses, užtikrinti mokymosi savikontrolę, pagerinti mokymosi procesą (Nicol et al. 2006). Formuojamuoju vertinimu įvertinama studento daroma pažanga, numatomos mokymosi kryptys (Sadler 1989). Kaip teigia M. Teresevičiené, D. Oldroyd, G. Gedvilienè (2004) šiuo vertinimu stengiamasi atsakyti i klausimą, ar mes teisingai viską atliekame, ar turime ką nors keisti, todèl atliekamas viso mokymosi proceso metu, kai siekiama suteikti tikslią informaciją apie tolesnes as- 
mens mokymosi ir tobulejjimo galimybes. Edukologai pažymi, kad formuojamas vertinimas būna ypač efektyvus, kai siejamas su nuolatiniu pasiekimų diagnozavimu ir grị̌žtamuoju ryšiu ir kai vertinimo rezultatai būna konfidencialūs (Kerevičienè et al. 2011). Formuojamasis vertinimas yra neatsiejama ispanų mokslininkų apibrèžto i e. mokymąsi orientuoto e. mokymosi rezultatų vertinimo modelio dalis (2.2 pav.). Apibrèžtus e. mokymosi rezultatus galima pasiekti ịtraukiant besimokančiuosius ị e. mokymosi rezultatų vertinimo procesą, planuojant e. mokymosi rezultatų vertinimą kaip neatsiejamą e. mokymosi procesą ir grižžtamuoju ryšiu koordinuojant studijas (Gomez et al. 2010).

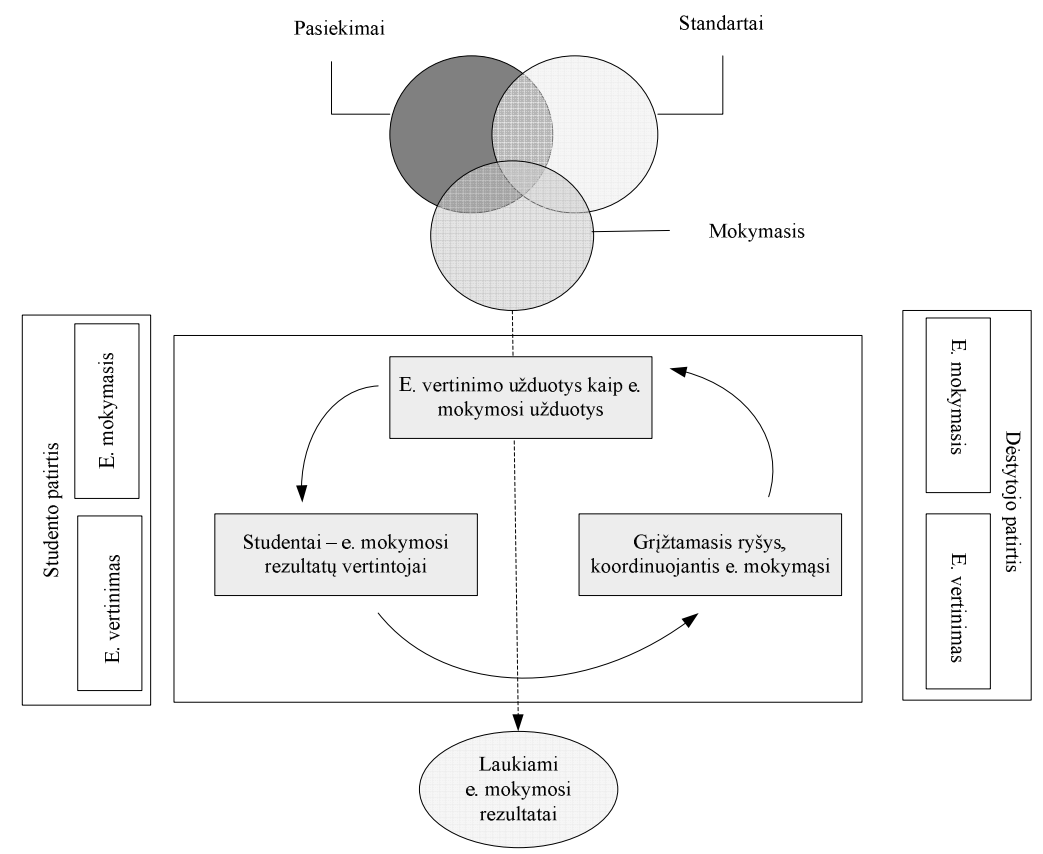

2.2 pav. E. mokymosi rezultatų vertinimo modelis (Gomez et al. 2010)

Fig. 2.2. E-learning assessment model (Gomez et al. 2010)

Apibendrinamasis vertinimas vyksta mokymosi proceso pabaigoje. Kadangi toks vertinimas atliekamas baigus dalyką, kursą, semestrą ar studijų programą, todèl kartais dar vadinamas baigiamuoju vertinimu (Bulajeva 2007). Vertinimo tikslas - apibendrinti, ką ir kaip besimokantysis išmoko (Kerevičienė et al. 2011). Apibendrinamuoju vertinimu stengiamasi suvokti ir įvertinti, ar tai, ką atliko, ką darè mokymo proceso dalyviai, buvo vertinga ir kaip vertinga (Teresevičienè et al. 2004). Šio vertinimo metu padarytos išvados ir priimti sprendimai padeda gerinti mokymosi kokybę (Kerevičienè et al. 2011). 
Kaupiamuoju vertinimu siekiama, kad studentas dirbtų per visą mokymosi procesą, o ne tik epizodiškai - ruošdamiesi kontroliniams darbams ar kitokiems atsiskaitymams (Kerevičienè et al. 2011). Organizuojant periodinị studentų pasiekimų vertinimą, studijų medžiaga suskirstoma i mažesnes dalis, studentai yra priversti nuolat dirbti, kad pasiruoštu kiekvienam vertinimo atvejui. Žemiau pateiktame paveiksle pavaizduotas studentu $A$ ir $B$ mokymosi pasiekimų igijimo kelias. Tarpiniai kurso vertinimai numatyti laiko momentais $T 1, T 2, T 3, T 4$. Nors kurso pabaigoje studento $A$ ir $B$ mokymosi pasiekimai yra vienodi, tačiau taikant kaupiamaji vertinimą, studentas $A$ ịvertinamas aukštesniu balu, kadangi jis sistemingai dirbo visą studijų laikotarpi ir geriau pasiruošè tarpiniams kurso vertinimams.

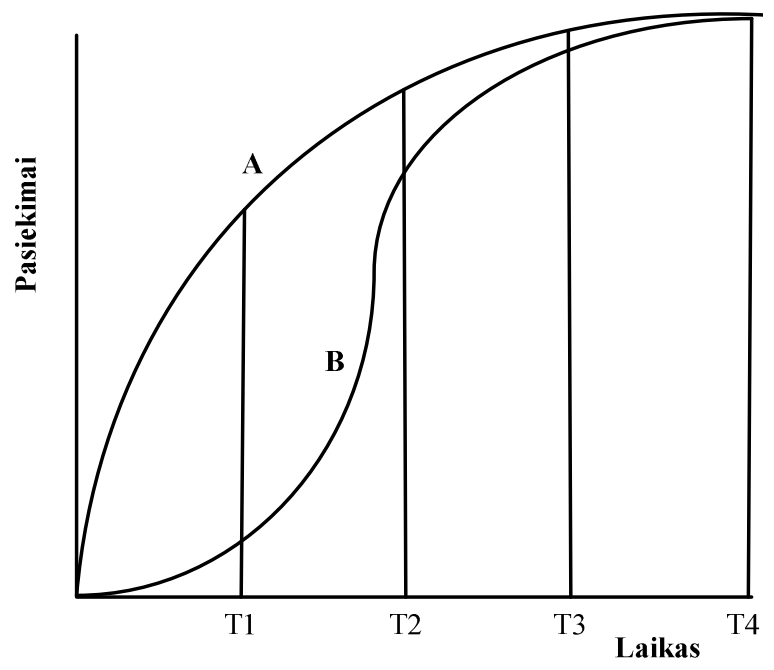

2.3 pav. Studentu $A$ ir $B$ pasiekimų kelias

Fig. 2.3. Achievement path of $A$ and $B$ students

Vertinimas mokymo procese dažnai suvokiamas nevienareikšmiškai (Kerevičiené et al. 2011). Kartais net viso mokymo proceso kokybès vertinimas yra siaurinamas iki ịgytų ar išmoktų žiniu įvertinimo, t. y. tam tikrų pažymių priskyrimo studentams (Kerevičiené et al. 2011). Vertinimo ir ịvertinimo sąvokos yra suvienodinamos, akcentuojant tik įvertinimo procesą. Tačiau pasak M. Teresevičienès, D. Oldroyd, G. Gedvilienès (2004), šios pedagoginio proceso dalys turi būti skiriamos. Ivertinimas apima sprendimo dèl studijų tikslų pasiekimo prièmimą (Teresevičiené et al. 2004) ir, kita vertus, - patị rezultatą (Laužackas et al. 2005). Vertinimas siejamas su informacijos apie studentus, ju studijas ir paties pedagogo mokymo procesą rinkimu, interpretavimu bei apibendrinimu (Kerevičienè et al. 2011). İvertinimas, kaip galutinis rezultatas, gali būti gaunamas pažymiais. Vertinimo rezultatai, išreiškiami pažymiais, gali turèti įvairią raišką: 
raidinę, skaitinę ir žodinę. Vertinimo rezultatų įforminimas tiesiogiai priklauso nuo aukštojo mokslo institucijoje taikomos vertinimo skalès. Lietuvos aukštosiose mokyklose naudojama skaitinè dešimties balų vertinimo skalè.

Ivertinant studentų pasiekimus, jų pasiekti rezultatai lyginami su normomis, kriterijais, standartais (Bulajeva 2007). Taikant norminị vertinimo modelį, besimokančiujų pažymiai tolygiai pasiskirsto pagal normalinę pažymių pasiskirstymo kreivę. Jei pasirinktas kriterinis studijų rezultatų vertinimo modelis, pažymys yra rašomas atsižvelgiant ị žinių ir gebejjimų atitikimą apibrèžtiems kriterijams. Rusų edukologas Š. K. Askerov studentų pasiekimų atitikimo apibrèžtiems kriterijams vertinti, skiria tiesini ir netiesini vertinimo modelius.

2.4 paveiksle pateiktas tiesinis vertinimo modelis dešimtbalèje vertinimo skalejje. Śio modelio esmè yra ta, kad vertinimo skalè dalijama ị tiek dalių, koks yra skalès dydis. Kiekvieną skalès vertinimą atitinka toks skalės ilgis, koks procentas žinių ir igūdžių būtinas šiam vertinimui igyti. Tarkime pažymys 5 rašomas studentams, kurie yra igiję 50 proc. dalyko žinių ir igūdžių. Vertinimo skalè dalijama ị dvi dalis: $L_{3}$ ir $L_{h} . L_{3}$ atitinka studentu pasiektus mokymosi rezultatus procentais, o $L_{h}$ - studentu nepasiektus mokymosi rezultatus procentais, $L$ - visos skalès ilgis. $L_{3}$ ir $L$ santykị $\breve{S}$. K. Askerov apibrèžè kaip santykinị išmokimą ir pažymèjo raide $a$.

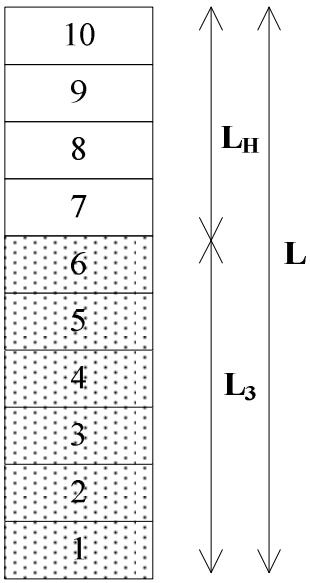

2.4 pav. Tiesinis vertinimo modelis (Askerov 2009)

Fig. 2.4. Linear assessment model (Askerov 2009)

Vertinimo skalès pažymių ir santykinio išmokimo priklausomybè pavaizduota 2.5 paveiksle. Santykinis išmokimas $a$ atitinka vertinimo kriterijus. Šio parametro reikšmé kinta intervale nuo 0 iki 1 . Augant santykinio išmokimo reikšmei, didejja ir studento vertinimas. Tarkime, studento santykinis išmokimo rodiklis $-0,8$, tuomet jo mokymosi pasiekimai vertinami -8 balais. 


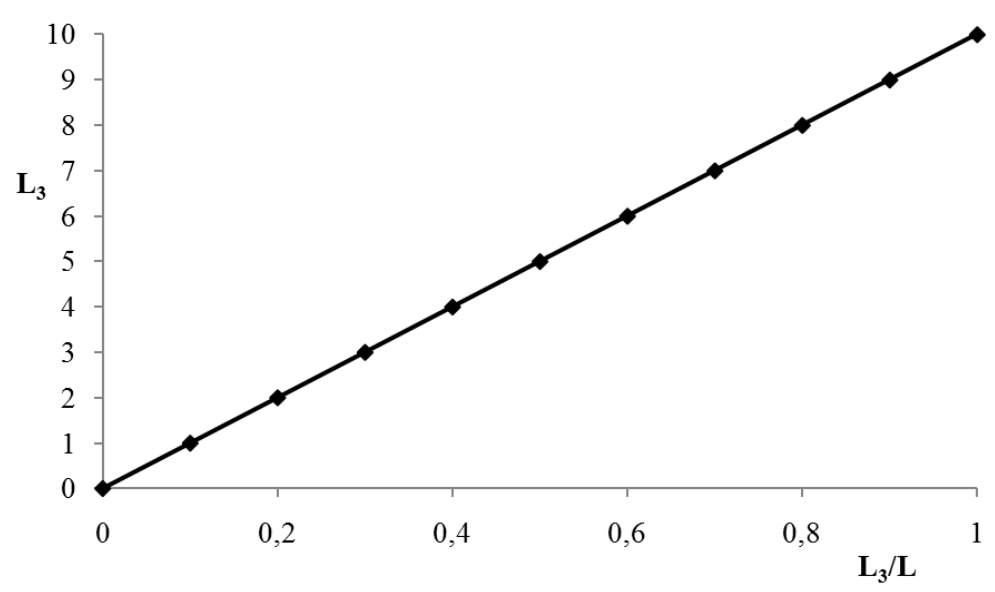

2.5 pav. Vertinimo skalès ir santykinio išmokimo priklausomybė (Askerov 2009)

Fig. 2.5. Relation between grading scale and relative learning (Askerov 2009)

Netiesinio vertinimo modelio kriterijus yra ne santykinis išmokimo $a$, o santykis dydžių išmoko $L_{3}$ ir neišmoko $L_{h}$. Šis dydis yra vadinamas kokybės faktoriumi ir žymimas $K$ raide. Akivaizdu, kad kokybès faktorius tenkina (2.1) lygybèmis aprašytus sąryšius.

$$
\begin{aligned}
& L_{3}<L_{H}, \text { kai } K<1 ; \\
& L_{3}=L_{H}, \text { kai } K=1 ; \\
& L_{3}>L_{H}, \text { kai } K>1 .
\end{aligned}
$$

Kokybès faktoriaus reikšmė yra mažesnè arba lygi 1, kai studento pasiekti mokymosi rezultatai yra ne didesni nei nepasiektieji. Netiesiniame vertinimo modelyje žinių ir igūdžių vertinimui naudojama kokybès faktoriaus $K$ priklausomybè nuo santykinio išmokimo $a$ (2.6 pav.). Dydžiui $a$ artejjant prie maksimalios reikšmès, t. y. 1 , kokybès faktorius $K \rightarrow \infty$, todèl, $k a d L_{H}$ artèja prie nulio. Studento vertinimas priklauso nuo jo pasiekto santykinio išmokimo koeficiento. Augant santykinio išmokimo reikšmei, didejja ir studento vertinimas.

Netiesinis vertinimo modelis užtikrina studentų reitingavimą (Askerov 2009). Kadangi kokybès faktorius $K$ kinta plačiame diapazone, todèl šio vertinimo modelio skale diferencijuoja studentus ir atitinka šiandienines vertinimo kaitos tendencijas (Askerov 2009). 


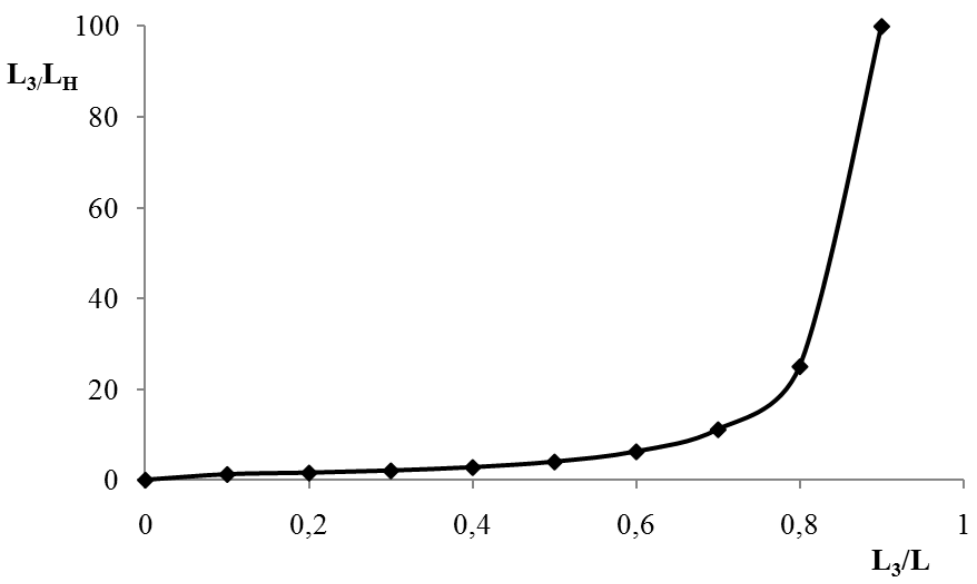

2.6 pav. Vertinimo skalès ir santykinio išmokimo priklausomybė (Askerov 2009)

Fig. 2.6. Relation between grading scale and relative learning (Askerov 2009)

Žinių ir igūdžių kiekis, tenkantis dydžiui $a$, tiesinio ir netiesinio modelio atveju ženkliai skiriasi. Tiesinio modelio atveju, kintant dydžiui $a$, ilgių $L_{3}$ ir $a$ santykis išlieka pastovus.

$$
\frac{d L_{3}}{d a}=\text { const }
$$

Netiesinio modelio atveju, didejant santykiniam išmokimui $a$, šis parametras sparčiai auga (Askerov 2009).

$$
\frac{d K}{d a}=\frac{1}{(1-a)^{2}}
$$

\subsection{Studijų rezultatụ vertinimo sistemų analizè}

Vertinimo sistema apibrèžiama kaip mokymo ir mokymosi rezultatų išreiškimo ir įforminimo tvarkos organizavimas (Rajeckas 1999). Pasak T. Bulajevos (2007) vertinimo rezultatai, išreiškiami pažymiais, gali turèti ịvairią raišką: raidinę (pažymiai - raidès A, B, C, D, E), skaitinę (pažymiai - skaičiai, balai) ir žodinę (įskaityta/neịskaityta, puikiai, labai gerai, gerai, vidutiniškai, patenkinamai, silpnai). Vertinimo sistemose rezultatų išreiškimas pažymiais apibrezžiamas vertinimo skale. Priklausomai nuo to kokią raišką - raidinę, skaitinę ar žodinę, turi pažymiai, skiriamos - raidinès, skaitinès ir žodinès vertinimo skalès.

Analizuojant įvairių šalių studijų rezultatų vertinimo sistemas, buvo remiamasi informacija, pateikta užsienio šalių švietimo ministerijų, studijų kokybės 
vertinimo centrų, aukštujų mokyklų, Europos švietimo informacijos tinklo Eurydice, akademinių švietimo informacijos centrų internetinèse svetainèse, nagrinèjami studijų rezultatų vertinimo tvarką apibrèžiantys ịstatymai, analizuojami moksliniai straipsniai. Nagrinejjant studijų rezultatų vertinimo sistemas, pagrindinis dèmesys buvo skiriamas Baltijos šalių, buvusių Tarybų Sajungos šalių, Šiaurès šalių, Balkanų pusiasalio šalių, Viduržemio jūros, Jungtinès Karalystės, Jungtinių Amerikos Valstijų, Tolimujų Rytų regionų valstybėms. Pasirinkti regionai skiriasi geografine padetimi, istorija, kalba, skirtingos ir šių regionų kultūrinès tradicijos. Jie atspindi ịvairius pasaulio požymius, išsivystymo lygị. Taigi apžvelgus pasirinktų regionų studijų rezultatų vertinimo sistemas, ivvertinami pasaulyje taikomų studijų rezultatų vertinimo sistemų panašumai ir skirtumai.

Baltijos šalis - Lietuvą, Latviją ir Estiją sieja ne tik geografinè vieta, bet ir istoriné, ekonominè ir politinè šių valstybių praeitis. Baltijos šalyse, kaip ir kitose buvusiose Tarybų Sajungos, šalyse studijų rezultatams vertinti ilgą laiką buvo taikoma keturbalè (žemiausias įvertinimas - 2, aukščiausias įvertinimas - 5) vertinimo sistema. Šią studijų rezultatų vertinimo sistemą lèmé ịvesta Tarybų Sąjungos švietimo sistema. Atkūrus Baltijos šalių valstybingumą, šiose šalyse pradètos švietimo sistemų pertvarkos.

1993 m. Lietuvoje, visuose švietimo lygmenyse, pereita prie dešimtbalès (aukščiausias ịvertinimas - 10) kriterinès vertinimo sistemos. Kriterinejje studijų rezultatų vertinimo sistemoje nustatoma, ar studentas yra išmokęs tiek, kiek reikalaujama pagal tam tikrą kriterijų. Nors dešimtbalè kriterinè vertinimo sistema Lietuvos švietimo institucijose buvo taikoma jau nuo 1993 metų, tačiau švietimo ir mokslo ministro įsakymu ši sistema buvo patvirtinta tik 2008 metais, t. y. po penkiolikos metų. $2008 \mathrm{~m}$. švietimo ir mokslo ministras A. Monkevičius patvirtino dešimtbalę studijų rezultatų vertinimo sistemą (Lietuvos Respublikos švietimo ir mokslo ministro ịsakymas dèl studijų rezultatų vertinimo sistemos patvirtinimo 2008 ISAK-2194). Patvirtintoje studijų rezultatų vertinimo sistemoje 5 yra minimalus teigiamas ịvertinimas. Pažymys atitinka pasiektų studijų tikslų procentą, skaičiuojant nuo dalyko programoje numatytos apimties. Šalia dešimtbalès vertinimo sistemos taikoma ịskaitymo ir neịskaitymo tvarka. Studentui iskaitomi studijuojamo dalyko rezultatai, jei pasiekta ne mažiau nei 50 proc. studijuojamo dalyko tikslų. Švietimo ir mokslo ministro A. Monkevičiaus patvirtintos studijų rezultatų vertinimo sistemos aprašas pateiktas 2.1 lentelèje. 
2.1 lentelè. Lietuvos studijų rezultatụ vertinimo sistema (Lietuvos Respublikos švietimo ir mokslo ministro įsakymas dèl studijų rezultatų vertinimo sistemos patvirtinimo 2008) Table 2.1. Grading system in Lithuania (Ministerial Order of Lithuania Education and Research on the Grading Scale 2008)

\begin{tabular}{|c|c|c|c|c|}
\hline Rezultatas & $\begin{array}{l}\text { Vertinimo } \\
\text { skalè }\end{array}$ & & Apibūdinimas & $\begin{array}{l}\text { Pasiekimai, } \\
\text { proc. }\end{array}$ \\
\hline \multirow[t]{6}{*}{ Išlaikyta } & 10 & \multicolumn{2}{|c|}{$\begin{array}{l}\text { PUIKIAI. Puikios, išskirtinès žinios ir ge- } \\
\text { bèjimai }\end{array}$} & 100 \\
\hline & 9 & \multicolumn{2}{|r|}{$\begin{array}{l}\text { LABAI GERAI. Tvirtos, geros žinios ir } \\
\text { gebèjimai }\end{array}$} & $>=90$ \\
\hline & 8 & \multicolumn{2}{|r|}{$\begin{array}{l}\text { GERAI. Geresnès nei vidutinès žinios ir } \\
\text { gebèjimai }\end{array}$} & $>=80$ \\
\hline & 7 & \multicolumn{2}{|c|}{$\begin{array}{l}\text { VIDUTINIŠKAI. Vidutinès žinios ir gebè- } \\
\text { jimai, yra neesminių klaidų }\end{array}$} & $>=70$ \\
\hline & 6 & \multicolumn{2}{|c|}{$\begin{array}{l}\text { PATENKINAMAI. Žinios ir gebèjimai } \\
\text { (igūdžiai) žemesni nei vidutiniai, yra klaidų }\end{array}$} & $>=60$ \\
\hline & 5 & \multicolumn{2}{|r|}{$\begin{array}{l}\text { SILPNAI. Žinios ir gebèjimai (igūdžiai) } \\
\text { tenkina minimalius reikalavimus }\end{array}$} & $>=50$ \\
\hline \multirow[t]{4}{*}{ Neišlaikyta } & \multirow[t]{4}{*}{$<=4$} & 4 & \multirow{4}{*}{$\begin{array}{l}\text { NEPATENKINAMAI. Netenkinami } \\
\text { minimalūs reikalavimai }\end{array}$} & \multirow[t]{4}{*}{$<50$} \\
\hline & & 3 & & \\
\hline & & 2 & & \\
\hline & & 1 & & \\
\hline
\end{tabular}

Patvirtinta studijų rezultatų vertinimo sistema susilaukè nemažai kritikos. Buvo akcentuojama, kad patvirtintoje studijų rezultatų vertinimo sistemoje įvertinimai apibūdinti lakoniškai, neatspindi studijų rezultatų vertinimo niuansų, ir tai sąlygoja ženklius įvertinimų skirtumus tarp skirtingų studijų sričių ir krypčių studentų. Igyvendinant Bolonijos proceso nuostatas, $2010 \mathrm{~m}$. švietimo ministro G. Steponavičiaus sudaryta darbo grupè parengè rekomendacijas studijų rezultatų vertinimui tobulinti. Kiekvienai aukštajai mokyklai buvo pasiūlyta patvirtinti savo studijų rezultatų vertinimo tvarką, atsižvelgiant i studijų srities, krypties ir studijuojamo dalyko specifiką.

Analogišką studijų rezultatų vertinimo modeli pasirinko ir dar viena buvusi Tarybų Sajungos šalis - Latvija. Skirtingai nuo Lietuvoje patvirtintos studijų rezultatu vertinimo sistemos minimalus teigiamas įvertinimas Latvijoje - 4 balai, 10 ir 9 balai yra skirti studentams, pademonstravusiems išskirtines žinias ir gebejimus (2.2 lentelè). T. Karran (2005), analizuodamas Latvijoje taikomą studijų rezultatų vertinimo sistemą, pastebejjo, kad šioje šalyje dažniau naudojami apatiniai šią vertinimo sistemą aprašančios vertinimo skalès pažymiai. Labai geras 
žinias ir įūdžius pademonstravę studentai šioje šalyje vertinami pažymiu - 8 . Lyginant lietuviškają ir latviškają studijų rezultatų vertinimo sistemas galime pastebèti, kad įvertinimas 10 (puikiai) latviškoje studijų rezultatų vertinimo sistemoje atitinka 9-10. Kaip Lietuvoje, taip ir Latvijoje aukštosios mokyklos naudoja institucijos poreikiams pritaikytas studijų rezultatų vertinimo sistemas ir netgi skirtingai apibrèžia minimalų teigiamą ịvertinimą, skirtingai interpretuoja aukščiausius vertinimo sistemos vertinimus. Bolonijos proceso inicijuoti pokyčiai palietė Latvijoje taikomą studijų rezultatų vertinimo sistemą. 2001 metais Latvijoje buvo atliekamas naudojamos studijų rezultatų vertinimo sistemų konvertavimo i ECTS vertinimo skalę tyrimas ir buvo parengta programine įranga, skirta konvertuoti Latvijos aukštojo mokslo institucijose gautus vertinimus i ECTS vertinimo skalę (Rauhvargers 2011).

2.2 lentelè. Latvijos studijų rezultatų vertinimo sistema (Latvijos Respublikos švietimo ir mokslo ministerija. Latvijos švietimo sistema 2009)

Table 2.2. Grading system in Latvia (Ministry of Education and Research, Latvia. The education system in Latvia 2009)

\begin{tabular}{|c|c|c|c|}
\hline Rezultatas & $\begin{array}{l}\text { Vertinimo } \\
\text { skalè }\end{array}$ & Apibūdinimas & $\begin{array}{l}\text { Pasiekimai, } \\
\text { proc. }\end{array}$ \\
\hline 1 & 2 & 3 & 4 \\
\hline \multirow[t]{7}{*}{ Išlaikyta } & 10 & $\begin{array}{l}\text { IŠSKIRTINAI: Žinios ir gebejjimai ženk- } \\
\text { liai lenkia vidutines žinias ir igūdžius }\end{array}$ & 100 \\
\hline & 9 & $\begin{array}{l}\text { PUIKIAI: Žinios ir gebejjimai lenkia vi- } \\
\text { dutines žinias ir ịgūdžius }\end{array}$ & 99 \\
\hline & 8 & $\begin{array}{l}\text { LABAI GERAI: Žinios atitinka aukš- } \\
\text { čiausią tikètiną lygmenị }\end{array}$ & $91-98$ \\
\hline & 7 & $\begin{array}{c}\text { GERAI: vidutinès žinios ir gebèjimai, } \\
\text { yra neesminių klaidų }\end{array}$ & $81-90$ \\
\hline & 6 & $\begin{array}{l}\text { BEVEIK GERAI: žinios ir gebejjimai } \\
\text { (igūdžiai) žemesni nei vidutiniai, yra } \\
\text { klaidų }\end{array}$ & $71-80$ \\
\hline & 5 & $\begin{array}{c}\text { PATENKINAMAI: žinios ir gebejimai } \\
\text { (igūdžiai) tenkina minimalius reikalavi- } \\
\text { mus }\end{array}$ & $61-70$ \\
\hline & 4 & $\begin{array}{l}\text { BEVEIK PATENKINAMAI: žinios ir } \\
\text { gebejjimai (igūdžiai) tenkina minimalius } \\
\text { reikalavimus. Paskutinis teigiamas verti- } \\
\text { nimas }\end{array}$ & $51-60$ \\
\hline
\end{tabular}


2.2 lentelès tẹsinys

\begin{tabular}{|c|c|c|c|}
\hline 1 & 2 & 3 & 4 \\
\hline \multirow{2}{*}{ Neišlaikyta } & $<=3$ & NEPATENKINAMAI & \multirow{2}{*}{$<=50$} \\
\cline { 3 - 3 } & & BLOGAI & \\
\cline { 3 - 3 } & & LABAI BLOGAI & \\
\cline { 3 - 3 } & & &
\end{tabular}

Estija ilgiausiai iš Baltijos šalių neturejo vieningos studijų rezultatų vertinimo sistemos. Iki 1999/2000 mokslo metų Estijoje buvo taikoma tiek penkiabalè, tiek šešiabalè studijų rezultatų vertinimo sistema (Europos švietimo informacijos tinklas 2009). 1999 metais Estijos švietimo ir mokslo ministras patvirtino 6 balu kriterinę studijų rezultatų vertinimo sistemą. Estijos mokymo institucijos, gali rinktis 6 balų raidinę vertinimo sistemą $(\mathrm{A}-\mathrm{F})$ arba studentų rezultatus vertinti 6 balu skaitine vertinimo sistema (5-0). Ivertinimai $\mathrm{A}|5, \mathrm{~B}| 4, \mathrm{C}|3, \mathrm{D}| 2$ ir $\mathrm{E} \mid 1$ yra teigiami, o įvertinimas $(\mathrm{F} \mid 0)$ yra neigiamas. Teigiamam įvertinimui gauti studento pasiekimų lygis turi būti ne mažesnis nei 51 proc.

2.3 lentelè. Estijos studijų rezultatų vertinimo sistema (Europos švietimo informacijos tinklas. Aukštasis mokslas Estijoje 2009)

Table 2.3. Grading system in Estonia (Network on education systems and policies in Europe. Higher Education in Estonia 2009)

\begin{tabular}{|c|c|c|c|}
\hline Rezultatas & Vertinimo skalè & Apibūdinimas & Pasiekimai, proc. \\
\hline \multirow{3}{*}{ Išlaikyta } & $5 \mid \mathrm{A}$ & Puikiai & $91-100$ \\
\cline { 2 - 4 } & $4 \mid \mathrm{B}$ & Labai gerai & $81-90$ \\
\cline { 2 - 4 } & $3 \mid \mathrm{C}$ & Gerai & $71-80$ \\
\cline { 2 - 4 } & $2 \mid \mathrm{D}$ & Patenkinamai & $61-70$ \\
\cline { 2 - 4 } & $1 \mid \mathrm{E}$ & Pakankamai & $51-60$ \\
\hline Neišlaikyta & $0 \mid \mathrm{F}$ & Nepakankamai & $0-50$ \\
\hline
\end{tabular}

Igyvendinant Bolonijos proceso nuostatas, aukštojo mokslo pertvarkos vykdomos ir kitose buvusiose Tarybų Sajungos šalyse: Arménijoje, Azerbaidžane, Baltarusijoje, Gruzijoje, Kazachijoje, Kirgizijoje, Moldavijoje, Rusijoje, Tadžikijoje, Turkmènijoje, Ukrainoje, Uzbekijoje. Šios pertvarkos inicijuoja minètu šalių studijų rezultatų vertinimo sistemų pokyčius. Šiose šalyse atnaujinama iš Tarybų Sajungos švietimo sistemos paveldeta keturbalè studijų rezultatų vertinimo sistema. В. М. Дианова (2008) akcentuoja, kad keturbalè studijų rezultatų vertinimo sistema neužtikrina tikslaus studentų igytų žinių ir igūdžių vertinimo. Siekiant objektyvesnio studentų pasiektų studijų rezultatų vertinimo, studento darbas turi būti vertinamas per visą semestrą, o ne tik per egzaminą (Дианова 
2008). Nors Armėnijos, Moldavijos, Gruzijos, Baltarusijos studijų rezultatų vertinimo sistemoje studentų pasiekimai vertinami vienoda dešimtbale vertinimo skale nuo 1 iki 10, tačiau skiriasi šios skalès taikymas. Arménijoje ir Gruzijoje paskutinis teigiamas šios vertinimu skalès vertinimas -4 , Baltarusijoje -3 (Борисова et al. 2009), o Moldavijos aukštojo mokslo institucijos turi teisę pasirinkti jiems priimtinesni minimalu teigiamą îvertinimą - 4 arba 5 (Репида 2009).

Kirgizijoje, Ukrainoje pasirinktas britiškasis studijų rezultatų vertinimo modelis. Ukrainos aukštosiose mokyklose studentai yra reitinguojami, taikant 100 balų (Шаталова et al. 2008), o Kirgizijos - 100 arba 20 balų (Абакирова 2010) vertinimo sistemų skales. Balai yra kaupiami visą semestrą. Ukrainos edukologai Т. С. Шаталова, В. В. Меженская, С. О.Савченко (2008) akcentuoja, kad reitingavimo sistema užtikrina objektyvų studentų pasiektų rezultatų vertinimą, skatina studentų mokymąsi visą semestrą, realizuoja kokybiškesnes studijas. Kirgizijos ir Ukrainos studijų rezultatų vertinimo sistemų taikymo skirtumai išryškejja konvertuojant sukauptus balus ị tradicinę - keturbalę, iš Tarybų Sajungos švietimo sistemos paveldètą vertinimo sistemą.

2.4 lentelè. Kirgizijos ir Ukrainos studijų rezultatų vertinimo sistemos (Абакирова 2010; Шаталова et al. 2008)

Table 2.4. Grading system in Ukraine and Kyrgyzstan (Абакирова 2010; Шаталова et al. 2008)

\begin{tabular}{|c|c|c|c|}
\hline Rezultatas & Vertinimo skalè & $\begin{array}{c}\text { Kirgizijos studiju } \\
\text { rezultatu vertinimo } \\
\text { skalè }\end{array}$ & $\begin{array}{c}\text { Ukrainos studiju } \\
\text { rezultatu vertinimo } \\
\text { skale }\end{array}$ \\
\hline \multirow{3}{*}{ Išlaikyta } & 5 (Puikiai) & $85-100 \mid 16-20$ & $91-100$ \\
\cline { 2 - 4 } & 4 (Gerai) & $75-85 \mid 12-16$ & $71-90$ \\
\cline { 2 - 4 } & 3 (Patenkinamai) & $61-75 \mid 8-12$ & $51-70$ \\
\hline Neišlaikyta & 2 (Nepatenkinamai) & $0-61 \mid 0-8$ & $0-50$ \\
\hline
\end{tabular}

Studijų rezultatų vertinimo sistemų ịvairovė būdinga Rusijai. Nors šalyje patvirtinta studijų rezultatu vertinimo sistema su keturbale vertinimo skale: 5(puikiai), 4(gerai), 3(patenkinamai), 2(blogai) (Petrovskaja et al. 2006), tačiau Rusijos aukštosios mokyklos aktyviai dalyvauja vykdomos švietimo reformos pertvarkose, analizuoja užsienio šaliu patirtị ir savo institucijose inicijuoja studijų rezultatų vertinimo sistemų pokyčius. Pavyzdžiui, Peterburgo universitete studentų žinioms ir igūdžiams vertinti taikoma tiek nacionalinè keturbale (5-2) vertinimo sistema, tiek amerikietiškoji raidinè, dešimtbalè (A, A-, B+, B, B-, $\mathrm{C}+, \mathrm{C}, \mathrm{C}-, \mathrm{D}, \mathrm{F})$ vertinimo sistema, studentų žinios ir gebejjimai, vertinami taikant kaupiamaji vertinimą. Valstybinis universitetas - aukštoji ekonomikos mo- 
kykla taiko dešimtbalę studijų rezultatų vertinimo sistemą nuo 1 iki 10, kuri ị keturbalę vertinimo sistemą konvertuojama taip: 1-3 (nepatenkinamai); 4-5(patenkinamai); 6-7 (gerai); 8-10 (gerai) (Радаев 2006). Šioje vertinimo sistemoje net trys vertinimai $(1,2,3)$ atitinka neigiamą pažymi, tačiau, pasak šios vertinimo sistemos autorių, skirtingi vertinimai būna ypač svarbūs, taikant kaupiamaji vertinimą (Радаев 2006). Rusijos valstybiniame humanitariniame universitete pasirinktas britiškasis studiju rezultatų vertinimo modelis ir ịvesta 100 balų reitinginè vertinimo sistema (Дианова 2008). 100 balų - tai maksimali balų suma, kurią studentas gali sukaupti per semestrą studijuodamas discipliną (Дианова 2008). Studijų knygelëje yra rašomas tiek vertinimas tradicine sistema, tiek 100 balų sistema. Vertinimai perskaičiuojami sekančiai: 60-74 balai (patenkinamai), 75-90 balų (gerai), 91-100 balų (puikiai) (Petrovskaja et al. 2006). Taigi Rusijoje nèra bendros studijų rezultatų vertinimo sistemos. Aukštojo mokslo institucijos renkasi studijų rezultatų vertinimo sistemas, tiksliausiai atitinkančias institucijoje vykdomų studijų specifiką.

Bene išskirtiniausią studijų rezultatų vertinimo sistemą iš buvusių Tarybų Sajungos šalių pasirinko Kazachija. Šalyje patvirtintos studijų rezultatų vertinimo sistemos skalę sudaro 11 raidžių. Skalès raidiniams vertinimams yra priskiriami skaitiniai atitikmenys. Studentų pasiekimai vertinami visą semestrą, taikant kaupiamaji vertinimą (Мутанов et al. 2010).

2.5 lentelè. Kazachijos studijų rezultatų vertinimo sistema (Мутанов et al. 2010)

Table 2.5. Grading system in Kazakhstan (Мутанов et al. 2010)

\begin{tabular}{|c|c|c|c|}
\hline Rezultatas & Vertinimo skalè & Apibūdinimas & Pasiekimai, proc. \\
\hline \multirow[t]{10}{*}{ Išlaikyta } & $4,00 \mid \mathrm{A}$ & \multirow{2}{*}{ Puikiai } & $95-100$ \\
\hline & 3,67|A- & & 90-94 \\
\hline & $3,33 \mid \mathrm{B}+$ & \multirow{3}{*}{ Gerai } & $85-89$ \\
\hline & $3,00 \mid \mathrm{B}$ & & $80-84$ \\
\hline & $2,67 \mid \mathrm{B}-$ & & $75-79$ \\
\hline & $2,67 \mid \mathrm{C}+$ & \multirow{3}{*}{ Patenkinamai } & $70-74$ \\
\hline & $2,00 \mid \mathrm{C}$ & & $65-69$ \\
\hline & $1,67 \mid \mathrm{C}-$ & & $60-64$ \\
\hline & $1,33 \mid \mathrm{D}+$ & & $55-59$ \\
\hline & $1,00 \mid \mathrm{D}$ & & $50-54$ \\
\hline Neišlaikyta & $0,00 \mid \mathrm{F}$ & Nepatenkinamai & $0-49$ \\
\hline
\end{tabular}


Šiaurès šalių regioną, apimantị penkias valstybes: Daniją, Islandiją, Norvegiją, Švediją ir Suomiją, sieja geografinè vieta, ilgalaikiai šalių ryšiai, kalbų lingvistinis panašumas, liuteroniškoji protestantizmo forma, bendras kultūrinis tapatumas. Pasak B. Dahl (2005), Šiaurès šalių regiono šalis sieja ir bendri švietimo tikslai, demokratinių vertybių puoselèjimas, mokymosi visą gyvenimą plètra. Lyginant Šiaures šalių studijų rezultatų vertinimo sistemų raidą, glaudžiausias sąsajas galima ižzelgti Norvegijos ir Danijos studijų rezultatų vertinimo sistemose. $2001 \mathrm{~m}$. Norvegijos parlamentas patvirtino aukštojo mokslo reformos, pavadintos Kokybès reforma, strategiją - Aukštojo mokslo baltaja knyga (Karseth 2005). Šia reforma pradètas Bolonijos proceso igyvendinimas: idiegta nauja kvalifikacinių laipsnių sistema, nauja kreditu sistema, pradètas igyvendinti naujas studijų programų modelis, kurio pagrindinè koncepcija - studijų rezultatų ivvedimas (Karseth 2005). Iki 2003 metų Norvegija neturejo patvirtintos nacionalinès studijų rezultatų vertinimo sistemos ir aukštojo mokslo institucijos galejo rinktis institucijos poreikius, vertinimo tradicijas atitinkančias vertinimo sistemas (Dahl et al. 2008).

Pasak B. Dahl, E. Lien, A. Linberg-Sand (2008), bendros studijų rezultatų vertinimo sistemos nebuvimas įtakojo studijų rezultatų vertinimo sistemų ịvairovę. Studijų rezultatams vertinti šalyje buvo naudojamos vertinimo sistemos, kuriose studentu pasiekimai buvo vertinami skaitinèmis ir raidinèmis vertinimo skalèmis, vienos aukštojo mokslo institucijos rinkosi didejjančias, kitos mažejančias vertinimo skales, buvo taikomos netgi binarinès vertinimo skalès (Dahl et al. 2008). Didžioji dalis Norvegijos aukštojo mokslo institucijų naudojo studijų rezultatų vertinimo sistemas, kuriose studentu pasiekimai buvo apibrèžiami skaitine vertinimo skale su lotyniškais arba lotyniškais ir norvegiškais atitikmenimis (Dahl et al. 2008). Studiju rezultatams vertinti buvo naudojami ne tik sveikieji, bet ir realieji skaičiai (Dahl et al. 2008).

Sparčiai augantys studentų mainai, galimybė rinktis modulius skirtingose aukštojo mokslo institucijose paskatino vieningos nacionalinès studijų rezultatų vertinimo sistemos Norvegijoje patvirtinimą. Norvegijoje, kaip ir Danijoje, nacionaline vertinimo sistema patvirtinta studiju rezultatų vertinimo sistema su septynbale vertinimo skale. Norvegija - pirmoji valstybè, kuri studijų rezultatams vertinti patvirtino ECTS vertinimo skalę A-F. Ši vertinimo skalè apibūdinama žodiniais vertinimo skalès aprašymais, reikalavimais teigiamų pažymių pasiskirstymui, vertinimo kriterijais. Vertinimo kriterijai apibrèžiami kiekvienai dèstomai disciplinai ir nusako reikalavimus vertinimo skalès pažymiams. Skirtingai nei ECTS vertinimo skale, Norvegijoje patvirtintos nacionalinès vertinimo skalès pažymių pasiskirstymo ribos nèra tokios griežtos (Dahl et al. 2008). Norvegijos studijų rezultatų vertinimo sistema aprašyta 2.6 lentelèje. 
2.6 lentelè. Norvegijos studijų rezultatų vertinimo sistema (Dahl et al. 2008)

Table 2.6. Grading system in Norway (Dahl et al. 2008)

\begin{tabular}{|c|c|c|c|c|}
\hline Rezultatas & $\begin{array}{c}\text { Vertinimo } \\
\text { skalè }\end{array}$ & Apibūdinimas & $\begin{array}{c}\text { ECTS pažymiu } \\
\text { pasiskirstymas, } \\
\text { proc. }\end{array}$ & $\begin{array}{c}\text { Vertinimo } \\
\text { skalès pažymių } \\
\text { pasiskirstymas, } \\
\text { proc. }\end{array}$ \\
\hline \multirow{3}{*}{ Išlaikyta } & $\mathrm{A}$ & Puikiai & 10 & $8-12$ \\
\cline { 2 - 5 } & $\mathrm{B}$ & Labai gerai & 25 & $20-30$ \\
\cline { 2 - 5 } & $\mathrm{C}$ & Gerai & 30 & $24-36$ \\
\cline { 2 - 5 } & $\mathrm{D}$ & Patenkinamai & 25 & $20-30$ \\
\cline { 2 - 5 } & $\mathrm{E}$ & Pakankamai & 10 & $8-12$ \\
\hline Neišlaikyta & $\mathrm{F}$ & Nepatenkinamai & & \\
\cline { 2 - 5 } & $\mathrm{FX}$ & Nepatenkinamai & & \\
\hline
\end{tabular}

Iki 1971 metų Danija neturejo patvirtintos, standartizuotos studijų rezultatų vertinimo sistemos. Aukštosios mokyklos, fakultetai ar atskiri padaliniai taike savo sukurtas ir institucijoje patvirtintas studijų rezultatu vertinimo sistemas. 1971 metais Danijos švietimo ir mokslo ministras patvirtino trylikabalę, kriterinę studijų rezultatų vertinimo sistemą (Dahl et al. 2008). Tačiau taikoma studijų rezultatų vertinimo sistema neužtikrino Danijoje ir kitose šalyse igytų ịvertinimu palyginamumo, viršutinè šios vertinimo sistemos skalès dalis (vertinimas - 13) buvo taikoma labai retai (Dahl et al. 2008). Igyvendinant Bolonijos proceso nuostatas, $2007 \mathrm{~m}$. Danijoje patvirtinta nauja septynbalè kriterinè studijų rezultatu vertinimo sistema, suderinta su ECTS vertinimo skale (Ministerial Order on the Grading Scale and Other Forms of Assessment of University Education 2007). Šioje vertinimo sistemoje 02 atitika minimalų teigiamą ịvertinimą. Naujajai studijų rezultatų vertinimo sistemai buvo keliami suderinamumo su ECTS vertinimo skale, apibrèžtais studijų rezultatais, visuotinio naudojimo, vidurkio apskaičiavimo reikalavimai (Dahl et al. 2008). Senosios ir naujosios studijų rezultatų vertinimo sistemų ryšiai pateikti 2.7 lentelèje. Danijos naująją studijų rezultatų vertinimo sistemą atitinkančioje vertinimo skaleje du vertinimai žymi neigiamus studentų pasiekimus. Neigiamiems vertinimo skalès pažymiams priskiriamas apibūdinimas - nepatenkinamai. Aukščiausią studijų rezultatų vertinimo sistemos skalès pažymi - 12, atitinka net trys senosios vertinimo skalès pažymiai 13-11. Naujosios studijų rezultatų vertinimo sistemos skalejje labai gerus studentų pasiekimus žymi vertinimas -10 , gerus -7 , patenkinamus -4 , pakankamus -02 . 
2.7 lentelè. Danijos senoji ir naujoji studijų rezultatų vertinimo sistema (Ministerial Order on the Grading Scale and Other Forms of Assessment of University Education 2007)

Table 2.7. The old and the new Danish grading system (Ministerial Order on the Grading Scale and Other Forms of Assessment of University Education 2007)

\begin{tabular}{|c|c|c|c|}
\hline Rezultatas & $\begin{array}{c}\text { Naujoji vertinimo } \\
\text { skale }\end{array}$ & Apibūdinimas & $\begin{array}{c}\text { Senoji vertinimo } \\
\text { skale }\end{array}$ \\
\hline Išlaikyta & 12 & Puikiai & $13-11$ \\
\cline { 2 - 4 } & 10 & Labai gerai & 10 \\
\cline { 2 - 4 } & 7 & Gerai & $9-8$ \\
\cline { 2 - 4 } & 4 & Patenkinamai & 7 \\
\cline { 2 - 4 } & 02 & Pakankamai & 6 \\
\hline Neišlaikyta & 00 & Nepatenkinamai & 03 \\
\cline { 2 - 4 } & -3 & Nepakankamai & 00 \\
\hline
\end{tabular}

ECTS vertinimo skalès ir Danijos naujosios studijų rezultatų vertinimo sistemos skalès sąryšiai pavaizduoti žemiau pateiktame paveiksle. Siekiant užtikrinti pažymių pasiskirstymo reikalavimus, buvo formuluojami vertinimo kriterijai. Aukštosios mokyklos rinkosi vertinimo kriterijų formulavimo principus. Vienos aukštojo mokslo institucijos vertinimo kriterijus apibrezżè naudodamos SOLO taksonomiją ir konstruktyvaus derinimo principus, kitos aukštosios mokyklos taikè Bloomo taksonomiją (Dahl et al. 2008).

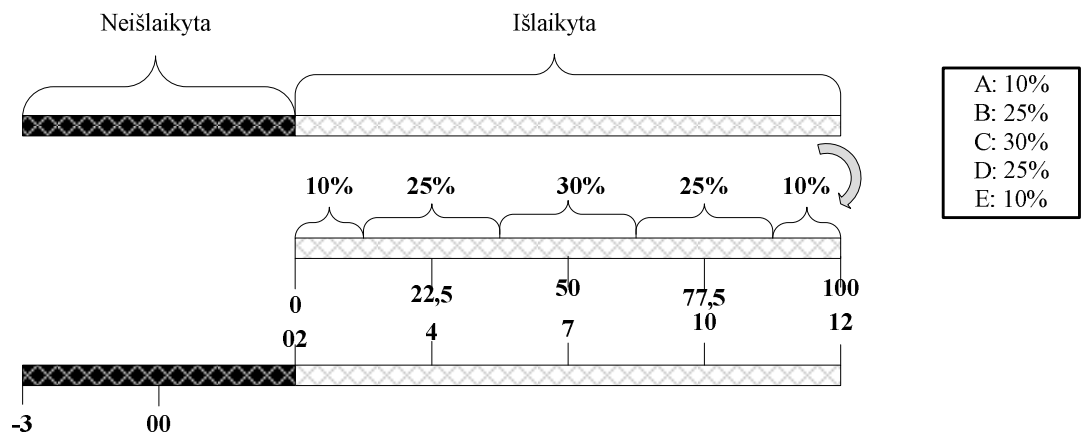

2.7 pav. ECTS ir Danijos naujosios studijų rezultatų vertinimo skalių sąryšiai (Dahl et al. 2008)

Fig. 2.7. The relation between the ECTS - scale and the new Danish grading scale (Dahl et al. 2008).

Suomija ir Švedija yra Šiaurès regiono šalys, kurios neturi patvirtintos bendros studijų rezultatų vertinimo sistemos. 1990 m. J. D. Hopkins analizuodamas 
Suomijos švietimo sistemą akcentavo, kad daugelis pagrindinių ir vidurinių mokyklų taiko vertinimo sistemą nuo 10 iki 4 (5 - mažiausias teigiamas įvertinimas), aukštosiose mokyklose studiju rezultatams vertinti naudojama vertinimo sistema nuo 3 iki 1 ( 3 - aukščiausias įvertinimas), o baigiamiesiems darbams vertinti naudojama atskira lotyniška vertinimų sistema: laudatur (puikiai), magna cum laude approbatur (labai gerai), lubenter (išlaikyta su pliusu), approbatur (išlaikyta) ir improbatur (neišlaikyta). Igyvendinant Bolonijos proceso nuostatas, daugelis Suomijos aukštujų mokyklų atnaujino ir pasitvirtino kriterines, su ECTS vertinimo skale suderintas studijų rezultatų vertinimo sistemas. Dalis Suomijos aukštujų mokyklų studijų rezultatams vertinti taiko šešiabalę kriterinę studijų rezultatų vertinimo sistemą $0-5$, kitos studijų rezultatus vertina septynių balų vertinimo sistema 1-7 (Evaluation of foreign degrees and qualifications in the Netherlands 2011).

2.8 lentelè. Suomijos studijų rezultatų vertinimo sistemos (Evaluation of foreign degrees and qualifications in the Netherlands 2011)

Table 2.8. The grading systems in Finland (Evaluation of foreign degrees and qualifications in the Netherlands 2011)

\begin{tabular}{|c|c|c|c|}
\hline Rezultatas & Vertinimo sistema $0-5$ & Vertinimo sistema 1-7 & Apibūdinimas \\
\hline Išlaikyta & 5 & $7-6$ & Puikiai \\
\cline { 2 - 4 } & 4 & 5 & Labai gerai \\
\cline { 2 - 4 } & 3 & 4 & Gerai \\
\cline { 2 - 4 } & 2 & 3 & Pakankamai \\
\cline { 2 - 4 } & 1 & 2 & Patenkinamai \\
\hline Neišlaikyta & 0 & 1 & Nepatenkinamai \\
\hline
\end{tabular}

Studijų rezultatų vertinimo sistemų ịvairovè būdinga ir Švedijai. Švedijos aukštosiose mokyklose taikomos studijų rezultatų vertinimo sistemos skiriasi institucijos, fakulteto, padalinio ir net kurso lygmenyje. Pavyzdžiui, Švedijos Lundo universitete naudojamos net keturios studijų rezultatų vertinimo sistemos: (išlaikyta išskirtinai - išlaikyta - neišlaikyta; 5-4-3 - neišlaikyta; išlaikyta išskirtinai - išlaikyta su kreditu - išlaikyta - neišlaikyta; išlaikyta - neišlaikyta) (Grading systems at Lund University 2011). Švedijos Karlstad ir Uppsala universitetuose naudojamos dvi studijų rezultatų vertinimo sistemos (VG (išlaikyta išskirtinai) - G (išlaikyta) - U (neišlaikyta); 5-4-3 - neišlaikyta) (Grading systems at Uppsala University 2011; Grading systems at Karlstad University 2011). 2007 metais Švedijos švietimo ir mokslo ministerija sudare darbo grupę - Vertinimo komitetą. Šis komitetas turejo įvertinti ECTS vertinimo skalès patvirtinimo nacionaline vertinimo skale galimybes. 2008 metais Švedijos švietimo ir mokslo 
ministro patvirtintose rekomendacijose studijų rezultatų vertinimo sistemai tobulinti, universitetams patiems paliekama laisvė nuspręsti, ar taikyti ECTS vertinimo skalę. Siūlymai taikyti septynbalę kriterinę studijų rezultatų vertinimo sistemą susilaukè nemažai kritikos. L. O. Dahlgren, A. Fejes, M. A. Dahlgren, N. Trowald (2008) pabrèžè, kad septynbalès kriterinès studijų rezultatų vertinimo sistemos įvedimas neišspręs skirtingose šalyse gautų ịvertinimų palyginamumo problemų, juk net Švedijos mokymo institucijose naudojami skirtingi vertinimo kriterijai.

Islandijos studijų rezultatų vertinimo sistema ženkliai skiriasi nuo kitų Šiaurès regiono šalių studijų rezultatų vertinimo sistemų. Islandijos aukštojo mokslo institucijos naudoja studijų rezultatų vertinimo sistemą nuo 0 iki 10 , kur 5 yra minimalus teigiamas iqvertinimas (Ministry of Education and Research, Iceland. Organisation of the education system in Iceland 2011). Šioje vertinimo sistemoje vertinimai yra rašomi žingsniu 0,5. Daugelis Islandijos aukštojo mokslo institucijų vertinimus grupuoja ị penkias žemiau pateiktoje lentelëje aprašytas grupes.

2.9 lentelè. Islandijos studijų rezultatų vertinimo sistema (Ministry of Education and Research, Iceland. Organisation of the education system in Iceland 2011)

Table 2.9. The grading system in Iceland (Ministry of Education and Research, Iceland. Organisation of the education system in Iceland 2011)

\begin{tabular}{|c|c|c|}
\hline Rezultatas & Vertinimo skale & Apibūdinimas \\
\hline \multirow{3}{*}{ Išlaikyta } & $9-10$ & Ǐskirtinai \\
\cline { 2 - 3 } & $7,25-8,99$ & Pirma klasė \\
\cline { 2 - 3 } & $6,0-7,24$ & Antra klasė \\
\cline { 2 - 3 } & $5,0-5,99$ & Trečia klasė \\
\hline Neišlaikyta & $<5$ & Neišlaikyta \\
\hline
\end{tabular}

Nors Balkanų pusiasalio šalis: Albaniją, Bosniją ir Hercegoviną, Bulgariją, Turkiją, Kroatiją, Kosovą, Makedoniją, Valakiją, Serbiją, Juodkalniją bei Slovèniją sieja kalbos panašumas, tačiau skiriasi šių šalių kultūra ir religija. Slovènai ir kroatai ilgą laiką priklause Austrijos ir Vengrijos imperijai, o kitoms tautoms didesnès itakos turèjo Bizantija. Bulgarijai teko svarbus vaidmuo formuojant slavų kultūrą. Balkanų pusiasalio šalių regionas pasižymi didele etnine įvairove. Analizuojant Balkano pusiasalio šalių studijų vertinimo sistemas, glaudžiausias sąsajas galima įžvelgti buvusių Jugoslavijos Respublikos valstybių: Serbijos, Slovenijos, Makedonijos, Bosnijos ir Hercogavinos, Juodkalnijos studijų rezultatų vertinimo sistemose. Šios šalys perèmé Jugoslavijos studijų rezultatų vertinimo sistemą ir studijų rezultatams vertinti taiko skaitinę kriterinę vertinimo skalę nuo 1 iki 10, kurios paskutinis teigiamas vertinimas yra 6 (Gaber 2008). Aukštojo 
mokslo institucijose taikoma studijų rezultatų vertinimo sistema detalizuojama, kiekvienam vertinimui apibrèžiant pasiekimų lygi procentais (2.10 lentelè).

2.10 lentelè. Serbijos, Slovėnijos, Makedonijos, Bosnijos ir Hercegovinos, Juodkalnijos studijų rezultatų vertinimo sistema (Gaber 2008)

Table 2.10. The grading system in Serbia, Slovenia, Macedonia, Bosnia \& Herzegovina, Montenegro (Gaber 2008)

\begin{tabular}{|c|c|c|c|}
\hline Rezultatas & Vertinimo skale & Apibūdinimas & Pasiekimai, proc. \\
\hline \multirow{3}{*}{ Išlaikyta } & 10 & Puikiai & $91-100$ \\
\cline { 2 - 4 } & 9 & Labai gerai & $81-90$ \\
\cline { 2 - 4 } & 8 & Labai gerai & $71-80$ \\
\cline { 2 - 4 } & 7 & Gerai & $61-70$ \\
\cline { 2 - 4 } & 6 & Patenkinamai & $51-60$ \\
\hline Neišlaikyta & $5-1$ & Neišlaikyta & $<50$ \\
\hline
\end{tabular}

Vienintele iš buvusių Jugoslavijos Respublikos valstybių - Kroatija - studijų rezultatams vertinti taiko skaitinę penkiabalę studijų rezultatų vertinimo sistemą, apimančią vertinimus nuo $1 \mathrm{iki} 5$ (Dopunska isprava o studiju. Upute, pravila i ogledni primjeri 2008). Paskutinis teigiamas šios vertinimo sistemos pažymys - 2 (2.11 lentelè).

2.11 lentelè. Kroatijos studijų rezultatų vertinimo sistema (Dopunska isprava o studiju. Upute, pravila i ogledni primjeri 2008)

Table 2.11. The grading system in Croatia (Dopunska isprava o studiju. Upute, pravila i ogledni primjeri 2008)

\begin{tabular}{|c|c|c|}
\hline Rezultatas & Vertinimo skale & Apibūdinimas \\
\hline \multirow{3}{*}{ Išlaikyta } & 5 & Išskirtinai \\
\cline { 2 - 3 } & 4 & Labai gerai \\
\cline { 2 - 3 } & 3 & Gerai \\
\cline { 2 - 3 } & 2 & Pakankamai \\
\hline Neišlaikyta & 1 & Nepakankamai \\
\hline
\end{tabular}

Šalia nacionalinès studijų rezultatų vertinimo sistemos aukštojo mokslo institucijoms rekomenduojama taikyti ECTS vertinimo skalę (Dopunska isprava o studiju. Upute, pravila i ogledni primjeri 2008). Kroatijoje taikoma kriteriné studijų rezultatų vertinimo sistema, tačiau studijų rezultatų vertinimo sistemą api- 
brěžiančiame įstatyme akcentuojama, kad atskiriems dalykams vertinti gali būti taikoma ir normomis grịsta studijų rezultatų vertinimo sistema.

Turkijos studijų rezultatų vertinimo sistema yra viena iš išskirtiniausių tarp Balkano pusiasalio šalių. Turkija neturi patvirtintos bendros studijų rezultatų vertinimo sistemos. Šios šalies aukštosios mokyklos taiko institucijoje patvirtintas studijų rezultatų vertinimo sistemas. Pavyzdžiui, Turkijos Bilkent universitete taikoma raidine studijų rezultatų vertinimo sistema (A, B, C, D, F, Fx), kur kiekvienam raidiniam vertinimui priskiriamas skaitinis atitikmuo $(4,3,2,1,0,0)$ (Bilkent university, Turkey. Grading System 2010). Minimalus teigiamas šios vertinimo sistemos pažymys - D(1) (Bilkent university, Turkey. Grading System 2010). Analogiška studijų rezultatų vertinimo sistema patvirtinta ir Turkijos Naval institute. Šio universiteto studijų rezultatų vertinimo sistemą sudaro raidiniai vertinimai su skaitiniais atitikmenimis $(\mathrm{AA}|4, \mathrm{BA}| 3,50, \mathrm{BB}|3,00, \mathrm{CB}| 2,50)(\mathrm{Na}-$ val science and engineering institute, Turkey. Erasmus information package 2010). Kiekvienas šios vertinimo sistemos pažymys detalizuojamas pasiekimo lygiu procentais.

Bulgarijos aukštosios mokyklos naudoja skaitinę kriterinę studijų rezultatų vertinimo sistemą nuo 2 iki 6 (6- aukščiausias šios skalès vertinimas) (Bulgarian - American Commission for Educational Exchange, Bulgaria. Main Grading System Used by Education Institutions in Bulgaria 2010). Mažiausias teigiamas šios vertinimo sistemos pažymys - 3 (2.12 lentelè). Kiekvieną šios vertinimo sistemos skalès pažymị apibréžia pasiekimų lygis procentais, kuris priklauso nuo aukštojo mokslo institucijos, studijų krypties ir srities.

2.12 lentelè. Bulgarijos studijų rezultatų vertinimo sistema (Bulgarian-American Commission for Educational Exchange, Bulgaria. Main Grading System Used by Education Institutions in Bulgaria 2010)

Table 2.12. The grading system in Bulgaria (Bulgarian-American Commission for Educational Exchange, Bulgaria. Main Grading System Used by Education Institutions in Bulgaria 2010)

\begin{tabular}{|c|c|c|c|}
\hline Rezultatas & Vertinimo skale & Apibūdinimas & $\begin{array}{c}\text { Pasiekimai, } \\
\text { proc. }\end{array}$ \\
\hline \multirow{3}{*}{ Išlaikyta } & 6 & Puikiai & $91,5-100$ \\
\cline { 2 - 4 } & 5 & Labai gerai & $80,5-91,4$ \\
\cline { 2 - 4 } & 4 & Gerai & $70,5-80,4$ \\
\cline { 2 - 4 } & 3 & Pakankamai & $59,5-70,4$ \\
\hline Neišlaikyta & 2 & Silpnai & $0-59,4$ \\
\hline
\end{tabular}


Lyginant didžiujų Viduržemio jūros regiono šalių: Ispanijos, Italijos, Graikijos, Prancūzijos studijų rezultatų vertinimo sistemas, glaudžiausias sąsajas galima rasti tarp Ispanijos ir Graikijos vertinimo sistemų. Ispanijos ir Graikijos aukštujų mokyklų studijų rezultatų vertinimo sistema apima vertinimus nuo 0 iki 10 , kur 5 yra minimalus sistemos pažymys. Vertinimai Ispanijoje yra grupuojami i penkias, o Graikijoje - i keturias žemiau pateiktoje lenteleje aprašytas grupes. Lyginant Ispanijos ir Graikijos studijų rezultatų vertinimo sistemas, skirtumus galima ižvelgti šių vertinimo sistemų taikymo praktikoje. Ispanijoje aukščiausias vertinimo sistemą aprašančios skalès pažymys - 10 yra rašomas studentams, pademonstravusiems išskirtines žinias ir gebejjimus. Ispanijos švietimo ir mokslo ministerijos puslapio pateiktame Ispanijos studijų rezultatų vertinimo sistemos apraše teigiama, kad aukščiausią kurso vertinimą gali gauti ne daugiau nei 5 proc. besimokančiujjų. Tačiau pasak F. Ayuga, A. I. Garcia (2004), aukščiausiu pažymiu dažniausiai ịvertinami tik 1-2 proc. studentų. Graikijos studijų rezultatų vertinimo sistemoje nèra išskiriamas pažymys, apibūdinantis išskirtines žinias ir gebejjimus. Ispanijos ir Graikijos studijų rezultatų vertinimo sistemų aprašas pateiktas 2.13 lentelèje.

2.13 lentelè. Ispanijos ir Graikijos studijų rezultatų vertinimo sistemos (Ministry of Education and Research, Spain. Credit and Grading Systems Spain 2011; Kyriazis 2008) Table 2.13. The grading system in Spain and France (Ministry of Education and Research, Spain. Credit and Grading Systems Spain 2011; Kyriazis 2008)

\begin{tabular}{|c|c|c|c|c|}
\hline Rezultatas & $\begin{array}{c}\text { Ispanijos } \\
\text { vertinimo skalè }\end{array}$ & Apibūdinimas & $\begin{array}{c}\text { Graikijos } \\
\text { vertinimo skalè }\end{array}$ & Apibūdinimas \\
\hline \multirow{3}{*}{ Išlaikyta } & $10-10$ & Išskirtinai & & \\
\cline { 2 - 5 } & $9,0-10$ & Labai gerai & $8,5-10$ & Puikiai \\
\cline { 2 - 5 } & $7,0-8,9$ & Gerai & $7-8,4$ & Labai gerai \\
\cline { 2 - 5 } & $5,0-6,99$ & Išlaikyta & $5-6,9$ & Gerai \\
\hline Neišlaikyta & $0-4,9$ & Neišlaikyta & $0-4,9$ & Neišlaikyta \\
\hline
\end{tabular}

Tiek Prancūzijoje, tiek Italijoje naudojamos platesnès ir daugiau diferencijuojančios studijų rezultatų vertinimo sistemų skalès. Italijoje studijų rezultatams vertinti naudojama trisdešimties balų vertinimo skalè 1-30 (Finocchietti et al. 2004). Septyniolika pirmujų šios skalès vertinimų yra skirti neigiamiems studijų rezultatams apibrèžti, 18 - pirmasis teigiamas šios skalès pažymys (2.14 lentelè). Baigiamieji egzaminai Italijoje vertinami skale 0-110, kur 66 - minimalus teigiamas pažymys (Finocchietti et al. 2004). Italijos edukologų M. Bagues, M. S. Labini, N. Zinovyeva (2008) atliktas tyrimas parode, kad nors Italijos universitetuose studijų rezultatams vertinti taikoma bendra studijų rezultatų vertinimo 
sistema, tačiau jos taikymo praktika skiriasi institucijos, padalinio, fakulteto lygmenyje.

2.14 lentelè. Italijos studijų rezultatų vertinimo sistema (Finocchietti et al. 2004)

Table 2.14. The grading system in Italy (Finocchietti et al. 2004)

\begin{tabular}{|c|c|c|}
\hline Rezultatas & Vertinimo skalè & Apibūdinimas \\
\hline \multirow{3}{*}{ Išlaikyta } & 30 & Išskirtinai \\
\cline { 2 - 3 } & $29-30$ & Puikiai \\
\cline { 2 - 3 } & $28-27$ & Labai gerai \\
\cline { 2 - 3 } & $26-24$ & Gerai \\
\cline { 2 - 3 } & $23-18$ & Patenkinamai \\
\hline Neišlaikyta & $0-18$ & Neišlaikyta \\
\hline
\end{tabular}

Prancūzijoje patvirtinta bendra studijų rezultatų vertinimo sistema tiek vidurinėms, tiek aukštosioms mokykloms (Malan 2004). Šioje šalyje studijų rezultatams vertinti naudojama vertinimo sistema su dvidešimties balų vertinimo skale, kurioje mažiausias teigiamas vertinimas -8 (2.15 lentelè). Skalès vertinimai yra grupuojami i septynias grupes, joms priskiriant žodinius atitikmenis. Pasak J. P. Douzals (2004), viršutiniai skalès vertinimai 18 - 20 yra skirti studentams, pademonstravusiems išskirtines žinias ir gebejjimus.

2.15 lentelè. Prancūzijos studijų rezultatų vertinimo sistema (Malan 2004)

Table 2.15. The grading system in France (Malan 2004)

\begin{tabular}{|c|c|c|}
\hline Rezultatas & Vertinimo skale & Apibūdinimas \\
\hline \multirow{4}{*}{ Išlaikyta } & $18-20$ & Sveikiname \\
\cline { 2 - 3 } & $16-17,9$ & Labai gerai \\
\cline { 2 - 3 } & $14-15,9$ & Gerai \\
\cline { 2 - 3 } & $12-13,9$ & Patenkinamai \\
\cline { 2 - 3 } & $10-11,9$ & Teisingai \\
\cline { 2 - 3 } & $8-10$ & Išlaikyta \\
\hline Neišlaikyta & $0-8$ & Neišlaikyta \\
\hline
\end{tabular}

Jungtinę Karalystę sudaro Didžioji Britanija (Anglija, Velsas ir Škotija) ir Šiaurès Airija. Švietimo sistema Jungtinèje Karalystejje yra decentralizuota dèl šalies regionu (Dagienè et al. 2008). Atsakomybę už skirtingus švietimo aptarnavimo aspektus dalijasi nacionalinè ir regioninès vyriausybès, bažnyčios, kitos 
nepriklausomos įstaigos bei švietimo ir mokymo įstaigos (Dagienè et al. 2008). Jungtineje Karalysteje taikoma studijų rezultatų vertinimo sistema skiriasi ne tik regiono, bet ir institucijos lygmenyje (International Qualifications Assessment Service 2007). Aukštojo mokslo institucijos naudoja skirtingas, tačiau bendrą struktūrą turinčias studijų rezultatų vertinimo sistemas. Studijų rezultatams vertinti taikoma studijų rezultatų vertinimo sistema su raidine vertinimo skale, kurios teigiamus pažymius žymi raidès - A, B, C, D, o neigiamus pažymius - E ir F. Šios studijų rezultatų vertinimo sistemos skales pažymiams yra priskiriami procentiniai atitikmenys. Vertinimai yra grupuojami i penkias klases (2.16 lentelè). T. Karran (2004) akcentuoja, kad Jungtinejje Karalystejje, vertinant studentų pasiektus studijų rezultatus, pažymiai vertinimo skalèje pasiskirsto netolygiai. Pirmosios klasès vertinimus gauna tik 8 proc. studentų (Karran 2004).

2.16 lentelè. Jungtinès Karalystės studijų rezultatų vertinimo sistema (International Qualifications Assessment Service 2007)

Table 2.16. The grading system in United Kingdom (International Qualifications Assessment Service 2007)

\begin{tabular}{|c|c|c|c|c|}
\hline Rezultatas & $\begin{array}{l}\text { Vertinimo ska- } \\
\text { lé }\end{array}$ & $\begin{array}{l}\text { Pasiekimai, } \\
\text { proc. }\end{array}$ & Apibūdinimas & Klasė \\
\hline 1 & 2 & 3 & 4 & 5 \\
\hline \multirow[t]{12}{*}{ Išlaikyta } & $\mathrm{A}+$ & $80-100$ & Išskirtinai & Pirma klasė \\
\hline & $\mathrm{A}$ & $75-79$ & \multirow{2}{*}{ Puikiai } & 1 \\
\hline & A- & $70-74$ & & \\
\hline & $\mathrm{B}+$ & $67-69$ & \multirow[t]{3}{*}{ Labai gerai } & \multirow{3}{*}{$\begin{array}{c}\text { Viršutinè antra } \\
\text { klasé } \\
2: 1\end{array}$} \\
\hline & B & $64-66$ & & \\
\hline & B- & $60-63$ & & \\
\hline & $\mathrm{C}+$ & $57-59$ & \multirow[t]{3}{*}{ Gerai } & \multirow{3}{*}{$\begin{array}{c}\text { Apatinė antra } \\
\text { klasè } \\
2: 2\end{array}$} \\
\hline & $\mathrm{C}$ & $54-56$ & & \\
\hline & $\mathrm{C}-$ & $50-53$ & & \\
\hline & $\mathrm{D}+$ & $47-49$ & \multirow[t]{3}{*}{ Patenkinamai } & \multirow{3}{*}{$\begin{array}{c}\text { Trečia klasė } \\
3\end{array}$} \\
\hline & $\mathrm{D}$ & $44-46$ & & \\
\hline & D- & $40-43$ & & \\
\hline \multirow[t]{2}{*}{ Neišlaikyta } & $\mathrm{E}+$ & $37-39$ & \multirow[t]{2}{*}{ Silpnai } & \multirow[t]{2}{*}{ Neišlaikyta } \\
\hline & $\mathrm{E}$ & $34-36$ & & \\
\hline
\end{tabular}


2.16 lentelès tęsinys

\begin{tabular}{|c|c|c|c|c|}
\hline 1 & 2 & 3 & 4 & \\
\hline \multirow{4}{*}{} & E- & $30-33$ & \\
\cline { 2 - 3 } & F + & $20-29$ & Labai silpnai & \\
\cline { 2 - 3 } & F & $10-19$ & & \\
\cline { 2 - 3 } & F- & $0-9$ & & \\
\hline
\end{tabular}

Jungtinių Amerikos Valstijų aukštojo mokslo sistema yra ypatinga tiek savo institucijų skaičiumi, tiek jų ịvairove bei siūlomų studijų programų gausa. Aukštosios mokyklos nèra ribojamos ar kontroliuojamos Švietimo ir Mokslo ministerijos. Tokios institucijos Jungtinèse Amerikos Valstijose net nèra (Rosenstone 2004). Vyriausybė registruoja aukštojo mokslo institucijas, bet nedaro itakos mokymo turiniui ar studijų eigai (Rosenstone 2004). Ilgą laiką Jungtinèse Amerikos Valstijose buvo taikoma keturbale mažejanti raidinè studijų rezultatų vertinimo sistema: E (puikiai), S (patenkinamai), N (reikia tobulèti), U (nepatenkinamai) (Altbach 2002). Dvidešimtojo amžiaus viduryje didžioji dalis aukštojo mokslo institucijų atnaujino studijų rezultatų vertinimo sistemas, pakeisdamos keturbalę studijų rezultatų vertinimo sistemą penkiabale, didejančia vertinimo sistema: A, B, C, D, F|E, kurios aukščiausias vertinimas - A, o pažymys F|E skiriamas neigiamiems vertinimams apibrèžti (Altbach 2002). Jungtinèse Amerikos valstijose taikomos studijų rezultatų vertinimo sistemos vertinimams priskiriami skaitiniai atitikmenys: $A=4,0, B=3,0, C=2,0, D=1,0, E \mid F=0,0$, igalinantys vertinimų vidurkio apskaičiavimą. Kai kuriose aukštojo mokslo institucijose studijų rezultatų vertinimo sistema praplečiama, ịvedant vertinimus, su ,-,“ arba su ,-,“ ir „+“ ženklais. Tuomet vertinimų skaitiniai atitikmenys igyja dvi: $\mathrm{B}-=2,5, \mathrm{~B}=3,0$ arba tris: $\mathrm{B}-2,7, \mathrm{~B}=3,0, \mathrm{~B}+=3,3$, skaitines reikšmes. Kai kuriose aukštojo mokslo institucijose studijų rezultatų vertinimo sistemos pažymiams nustatomi žinių ir gebejjimų pasiekimo lygmenys: A - 92-100\%, B - 83-91\%, $\mathrm{C}-74-82 \%$, D $-65-73 \%$, E|F $-\leq 64 \%$ (Rosenstone 2004). Keletas liberaliu meno koledžų Jungtinèse Amerikos valstijose visiškai nenaudoja jokios studijų rezultatų vertinimo skalès, o studentams pateikia pasiektų mokymosi rezultatų aprašus (Rosenstone 2004).

Apžvelgdami Tolimųų Rytų regioną, panagrinèsime dvi didžiausias šio regiono šalis - Japoniją ir Kiniją. Japonų švietimo sistema vertinama kaip viena geriausių pasaulyje (Šalna 2007). Tą patvirtina ir įvairūs tarptautiniai tyrimai, kuriuose ši šalis užima pirmąsias vietas (Šalna 2007). Patys japonai laikosi nuostatos, kad tik aukštas visuomenès išsimokslinimas gali garantuoti ilgalaiki valstybès klestejjimą (Šalna 2007). Japonijos aukštosiose mokyklose taikoma raidinè keturbalè: A $(80-100 \%)$, B $(70-79 \%)$, C $(60-69 \%)$, F $(0-59 \%)$ arba raidinè penkiabalè: A (90-100\%), B (80-89\%), C (70-79\%), D (60-69\%), E|F (0-59\%) 
studijų rezultatų vertinimo sistema. Šiose studijų rezultatų vertinimo sistemose pažymiai $\mathrm{F}$ ir $\mathrm{E} \mid \mathrm{F}$ žymi neigiamus vertinimus.

Kinija - didžiausia gyventojų skaičiumi šalis. Kinijoje vyrauja socialistinè ideologija, pagrịsta kolektyvinèmis pastangomis ir griežta hierarchija (Foster 2004). 1952 metais Kinijoje buvo vykdoma aukštojo mokslo reforma. Pertvarkant Kinijos aukštojo mokslo sistemą, buvo pasirinktas Tarybų Sajungos švietimo modelis (Kang 2004). Švietimas buvo politizuotas ir ideologizuotas (Kang 2004). Kinijos universitetus kontroliavo vyriausybe, kurią koordinavo komunistų partija (Kang 2004). Pasak O. Kang (2004), naujoji švietimo reforma Kinijoje prasidejjo 1998 metais (Kang 2004). Šiandien Kinijos universitetai tampa mažiau politizuoti, vis didesnis demesys skiriamas moksliniams tyrimams vykdyti, didèja aukštojo mokslo finansavimas, aukštasis mokslas internacionalizuojasi (Kang 2004). Kinijos ir Japonijos studijų rezultatų vertinimo sistemose galime įžvelgti glaudžias sąsajas. Kinijoje, kaip ir Japonijoje, studentų pasiekimai vertinami raidėmis, kiekvienam vertinimui apibrèžiant pasiekimų lygmeni procentais, kurie visiškai atitinka Japonijoje taikomos penkiabalès vertinimo sistemos skalès lygmenis (2.17 lentelè).

2.17 lentelè. Kinijos studijų rezultatų vertinimo sistema (Hohner et al. 2010)

Table 2.17. Chinese grading system (Hohner et al. 2010)

\begin{tabular}{|c|c|c|c|}
\hline Rezultatas & Vertinimo skalė & Apibūdinimas & Pasiekimai, proc. \\
\hline \multirow{3}{*}{ Išlaikyta } & $\mathrm{A}$ & Išskirtinai & $90-100$ \\
\cline { 2 - 4 } & $\mathrm{B}$ & Puikiai & $80-89$ \\
\cline { 2 - 4 } & $\mathrm{C}$ & Labai gerai & $70-79$ \\
\cline { 2 - 4 } & $\mathrm{D}$ & Gerai & $60-69$ \\
\hline Neišlaikyta & $\mathrm{F}$ & Neišlaikyta & $0-59$ \\
\hline
\end{tabular}

Pasiektiems studijų rezultatams vertinti taikomos skirtingos vertinimo sistemos, kurių ištakos glūdi giliose pedagogikos ir kultūros. Atlikta studijų rezultatų vertinimo sistemų analizè parodè, kad studijų rezultatų vertinimas skiriasi šalies, studijų krypties ir institucijos lygmenyse. Daugelyje šalių naudojamos studiju rezultatų vertinimo sistemos su skaitinėmis vertinimo skalèmis, tačiau Norvegijoje, Švedijoje, Jungtinėse Amerikos valstijose, Jungtinejje Karalysteje, Japonijoje, Kinijoje studentų pasiekimai vertinami ne skaičiais, o raidėmis. Estijos aukštosios mokyklos renkasi vertinimo sistemą su skaitine arba raidine vertinimo skale. Vertinimo sistemų ịvairovè būdinga Rusijai, Švedijai. Studijų rezultatų vertinimo sistemų analizè parodè, kad pasaulio aukštosios mokyklos dažniausiai renkasi kriterinį studijų rezultatų vertinimo sistemų modelį. 
Daugelio šalių studijų rezultatų vertinimo sistemų skalès yra didejjančios, t.y. aukštesni vertinimą atitinka aukštesnis balas. Tačiau Čekijoje, Austrijoje studentu pasiekimams vertinti taikomos mažejjančios vertinimo skalès. Skiriasi ne tik vertinimo skaliu žymejjimas, bet ir dydis. Lietuvoje, Latvijoje, Serbijoje, Slovenijoje, Makedonijoje, Bosnijoje ir Hercegovinoje, Juodkalnijoje naudojama vertinimo sistema su dešimtbale vertinimo skale. Estai, suomiai studentu pasiekimus vertina šešiabale vertinimo skale. Švedijos aukštosiose mokyklose naudojamos trijų arba keturių balų vertinimo skalès. Populiarèja studijų rezultatų vertinimos sistemos su labiau diferencijuojančiomis vertinimo skalèmis. Prancūzijoje studentų pasiekimai vertinami dvidešimties balų vertinimo skalèje, Italijos desstytojai taiko trisdešimties balų vertinimo skalę. Studentų pasiekimai šimtabale vertinimo skale apibrèžiami Ukrainoje, Kirgizijoje, kai kuriose Rusijos aukštosiose mokyklose.

Studijų rezultatų vertinimo sistemų skalès yra dalijamos ị dvi dalis: teigiamus ir neigiamus vertinimus. Daugelyje šalių yra naudojamos vertinimo skalès, kurių teigiami vertinimai apima didžiąą skalès dalį. Lietuvoje teigiamiems vertinimams skiriami šeši, Latvijoje - septyni, o Serbijoje, Slovėnijoje, Makedonijoje, Bosnijoje ir Hercegovinoje, Juodkalnijoje - tik penki dešimtbalès vertinimo skalès pažymiai.

Skiriasi ne tik įvairių šalių studijų rezultatų vertinimo sistemos, bet ir jų taikymo praktika. Prancūzijoje dažniau naudojami apatinès skalès dalies pažymiai, Italijoje - viršutinès skalès dalies. Tačiau Italijoje, kaip ir Latvijoje, Prancūzijoje, aukščiausias vertinimo skalès pažymys skirtas išskirtines žinias ir gebejjimus pademonstravusiems studentams, todèl šis pažymys rašomas ypač retai. Italijos institucijų inžinerijos studijų studentai vertinami žemesniais pažymiais nei humanitarinių mokslų.

Atlikus studijų rezultatų vertinimo sistemų analizę, pastebèta, kad studijų rezultatų vertinimo sistemos skalès pažymiams yra priskiriami žodiniai apibūdinimai. Minimalūs teigiami vertinimai įvairių šalių studijų rezultatų vertinimo sistemose apibrěžiami kaip „Patenkinamai“ arba „Pakankamai“, „Trečia klasė“. Lietuvoje minimalus teigiamas ìvertinimas apibrēžiamas „Silpnai“. İvairiose šalyse skirtingai apibréžiami reikalavimai minimaliam teigiamam ịvertinimui gauti. Serbijos, Slovénijos, Makedonijos, Bosnijos ir Hercegovinos, Juodkalnijos, Estijos, Latvijos, Lietuvos studijų rezultatų vertinimo sistemoje apibréžiama, kad teigiamam įvertinimui gauti studento žinių ir gebejimų lygis procentais turi būti didesnis nei 50 proc. Jungtineje Karalystejje teigiamas ịvertinimas rašomas studentams, kurių pasiekimų lygis procentais yra ne mažesnis nei 40 proc. Aukštesni reikalavimai yra keliami Jungtinèse Amerikos Valstijose, Kinijoje, Japonijoje, Turkijoje. Šiose šalyse teigiamam įvertinimui gauti pasiekimų lygis procentais turi būti ne mažesnis nei 60 proc. 


\subsection{Pažymių konvertavimo metodikos parinkimas}

Parenkant pažymių konvertavimo metodiką, nagrinejjami ịvairūs vertinimų konvertavimo būdai. Atlikta studijų rezultatų vertinimo sistemų apžvalga ir analizé parodè, kad studijų rezultatų vertinimo sistemų skalès aprašomos žodiniais apibūdinimais. Pažymių konvertavimo būdas, ịvertinantis studijų rezultatų vertinimo sistemų skalių žodinius apibūdinimus, nèra tinkamas pažymiams iš vienos vertinimo skalès ị kitą konvertuoti. Žodiniai vertinimo skalių aprašymai yra lakoniški, paviršutiniškai apibrezžiantys pasiektus mokymosi rezultatus, neatskleidžiantys studijų rezultatų vertinimo skalès taikymo praktikos.

Tęsiant analizę, ịvertinamas antrasis pažymių konvertavimo būdas - studijų rezultatų vertinimo skalès aprašymas pasiekimų lygmenimis procentais. Šio pažymių konvertavimo būdo taikymas vertinimams konvertuoti yra problemiškas, kadangi ne visos studijų rezultatų vertinimo skalès aprašomos, nurodant pasiekimų lygi procentais, jis neatskleidžia studijų rezultatų vertinimo skalès taikymo praktikos, ne visose studijų rezultatų vertinimo sistemose pasiekimų lygis susiejamas su pasiektais studijų rezultatais.

Trečias pažymių konvertavimo būdas - vertinimų konvertavimas, naudojant ECTS vertinimo skalę. Ši vertinimo skalè yra ECTS sistemos dalis. ECTS sistema buvo sukurta, siekiant nustatyti bendrus akademinių rezultatų pripažinimo principus. ECTS vertinimo skale skirta užtikrinti pažymių gautu skirtingose šalyse, institucijose ar studijų kryptyse skaidrumą, suprantamumą, palyginamumą. Śia skale buvo rekomenduojama vadovautis greta nacionalinès pažymių skalès. ECTS vertinimo skalé grindžiama statistiniu teigiamų vertinimų pasiskirstymu kiekvienoje programoje (ECTS User Guide 2009). ECTS vertinimo skalè yra normine (Karran 2004). Tai išryškina, nacionalinès vertinimo skalės naudojimo ypatumus, leidžia palyginti įvairiose institucijose teikiamos studijų programos statistinị pažymių pasiskirstymą. ECTS vertinimo skalè papildo nacionalinę vertinimo skalę, tačiau jos nepakeičia. B. Dahl, E. Lien, A. Linberg-Sand (2009) akcentuoja, kad ECTS vertinimo skalè yra tik pagalbiné priemoné, interpretuojant studentu gautus vertinimus. ECTS vertinimo skalè remiasi sukaupta vertinimų statistika, naudojant šią vertinimo skalę galima interpretuoti tiek kriterinès, tiek norminès vertinimo sistemų pažymius.

Pirmasis ECTS vertinimo skalès diegimo etapas - statistinių duomenų rinkimas. Statistiniai duomenys iliustruoja nuoseklų vertinimo modeli. Antrajame etape, diegiant ECTS vertinimo skalę, kiekvienos kontrolinès grupés statistinių teigiamu pažymių pasiskirstymo kreive padalijama i penkias dalis (geriausių/aukščiausių $10 \%$, kiti $25 \%$, kiti $30 \%$, kiti $25 \%$, žemiausių $10 \%$ ), vadinamas A, B, C, D, E (2.8 pav.). Vertinimai A, B, C, D, E turejo tapti tiesiogine priemone, verčiant vienoje šalyje gautus pažymius i kitos šalies pažymius. 


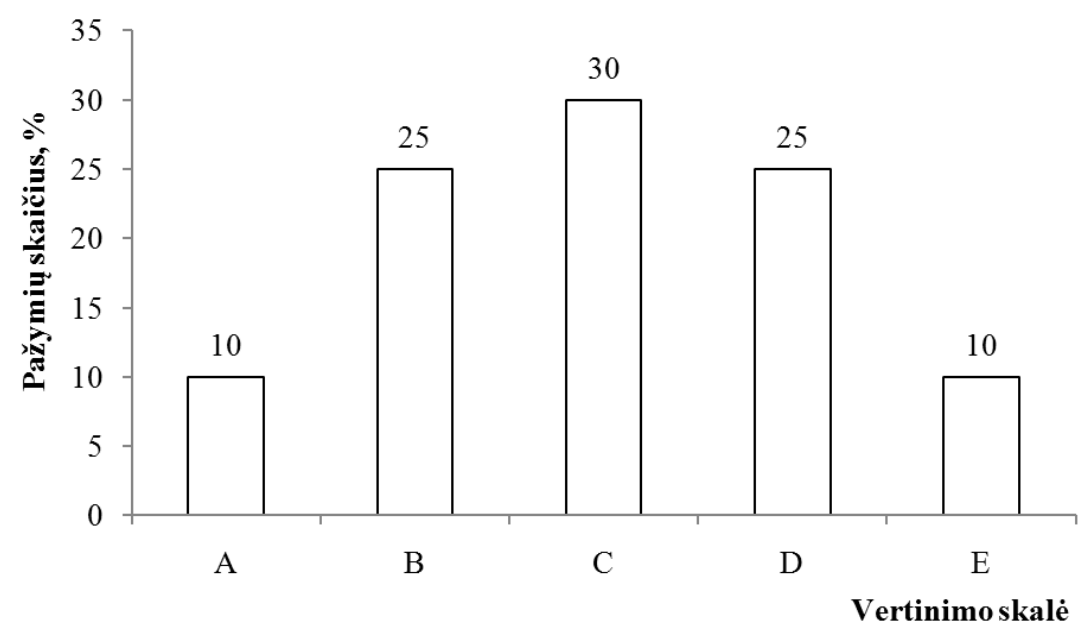

2.8 pav. Statistinis teigiamų pažymių pasiskirstymas ECTS vertinimo skalëje (ECTS User Guide 2009)

Fig. 2.8. Statistical distribution of positive grades in ECTS grading scale (ECTS User Guide 2009)

Norvegija yra vienintele šalis, nacionaline vertinimo skale pasitvirtinusi ECTS vertinimo skalę (Dahlgren et al. 2006). Tačiau pasak B. Dahl, E. Lien, A. Linberg-Sand (2009), šioje šalyje pasirinktas tik ECTS vertinimo skalès žymejjimas, o vertinimo sistemos modelis išlikęs kriterinis.

ECTS vertinimo skalè susilaukè nemažai kritikos. P. Warfvinge (2008) pabrèžia, kad pasirinktas norminis ECTS vertinimo skalès modelis nesuderinamas su daugelio šalių pedagoginès kultūros tradicijomis. Taikant ECTS vertinimo skalę, ịvedamas studentu reitingavimas, kuriam nepritaria švedų edukologai. Pasak L. Dahlgren, A. Fejes, M. A. Dahlgren, N. Trowald (2006), studentų reitingavimas prieštarauja studentų bendradarbiavimui ir sąveikai, kurie skatina efektyvų studentų mokymąsi.

Diegiant ECTS vertinimo skalę aukštosiose mokyklose, išryškèjo šios vertinimo skailès taikymo problemos. Pasak T. Karran (2004), daugelis Europos aukštujų mokyklų ECTS vertinimų skalę naudoja neatsižvelgdamos ị jos apibrèžimo esmę. Universitetų naudojamos kriterinès vertinimo skalès yra tiesiogiai konvertuojamos į ECTS vertinimo skalę, net neatsižvelgiant į pažymių pasiskirstymo reikalavimus (Warfvinge 2008). Pasak P. Warfvinge (2008), aukštosios mokyklos renkasi lengvesnę nors ir neteisingą ECTS taikymo praktiką, kuri nereikalauja atsižvelgti $\mathfrak{i}$ ankstesnių vertinimų duomenis bei reitinguoti studentus. T. Karran (2004) atlikta dvidešimties Europos universitetų ECTS vertinimo skalès taikymo studija parodè, kad atskirų šalių universitetuose apibrèžiami skirtingi nacionalinès vertinimo skalès ECTS pažymių atitikmenys, nors ECTS vertinimų 
skalè yra norminè, o nacionalinè - kriterinè, tačiau pažymiai tiesiogiai konvertuojami iš vienos vertinimo skalès ị kitą.

Didžioji dalis aukštojo mokslo institucijų taiko 2.9 paveiksle pavaizduotą pažymių, naudojant ECTS vertinimo skalę, konvertavimo schemą. Pažymių konvertavimas i ECTS vertinimo skalę ir iš ECTS vertinimo skalès vykdomas priskiriant maksimalų galimą atitikmenį. Akivaizdu, kad toks pažymių konvertavimas nèra tikslus. Vykdant tiesioginị ir atvirkštinį pažymių konvertavimą, gaunama vertinimų konvertavimo neatitikimo atvejų. Žemiau pateiktame paveiksle pavaizduotas šalių $A$ ir $B$ vertinimo skalių pažymių pasiskirstymas. S̆alies $A$ pažymiui 9 priskiriamas maksimalus ECTS vertinimo skalès atitikmuo, t. y. vertinimas A. Si vertinimą konvertuojant $\mathfrak{i}$ šalies $B$ vertinimo skalę, priskiriamas maksimalus vertinimo atitikmuo, t. y. pažymys 6 . Vykdydami atvirkštini pažymio 6 konvertavimą gauname, kad šalies $A$ vertinimo skalèje šiam pažymiui priskiriamas vertinimas 10 (2.9 pav.). Taigi gaunamas konvertavimo neatitikimo atvejis.

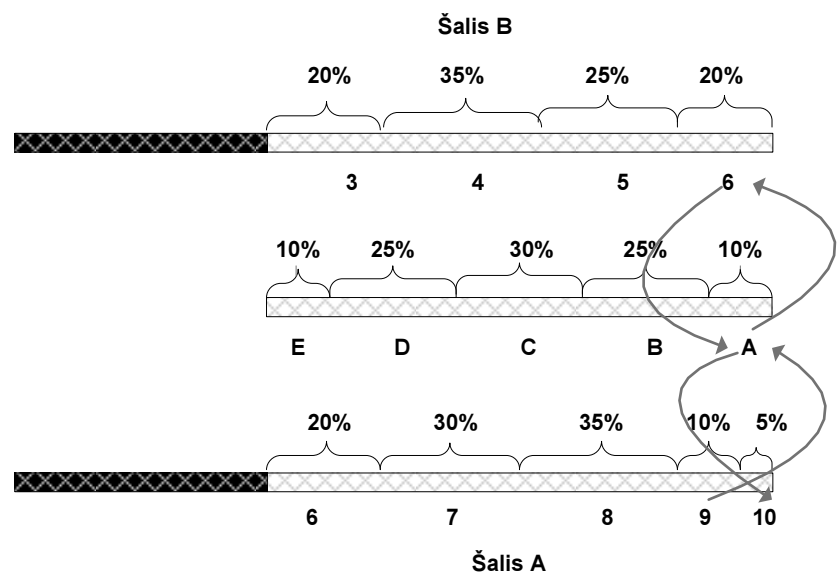

2.9 pav. Pažymių konvertavimas, taikant ECTS vertinimo skalę

Fig. 2.9. Grade transfer using ECTS grading scale

Konvertuojant pažymius, taikant ECTS vertinimo skalę, vertinimai iš vienos studijų rezultatų vertinimo skalès i kitą yra konvertuojami per tarpinius - ECTS vertinimus. Toks pažymių konvertavimo būdas nèra patogus, didejja konvertavimo paklaidos tikimybè.

Tęsiant analizę, ìvertinamas ketvirtasis pažymių konvertavimo būdas - vertinimų konvertavimas ECTS vertinimų lentelès pagrindu. ECTS vertinimų lentelè grindžiama pirmuoju penkiabalès sistemos etapu (ECTS User Guide 2009). Taigi institucijoms tereikia pateikti standartinę lentelę, rodančią statistinị teigiamų pažymių pasiskirstymą studijų programoje ar panašių programų grupejje (ECTS User Guide, 2009). ECTS vertinimo skale grindžiama nustatyta procen- 
tine struktūra, keičiama paprasta statistine lentele, sudaryta studijų programai ar panašių programų grupei.

2.18 lentelè. ECTS vertinimų lentelè (ECTS User Guide 2009)

Table 2.18. ECTS grading table (ECTS User Guide 2009)

\begin{tabular}{|c|c|c|}
\hline $\begin{array}{c}\text { Nacionalinis/institucinis } \\
\text { pažymys }\end{array}$ & $\begin{array}{c}\text { Bendras skaičius gavusių } \\
\text { kontrolinëje grupëje }\end{array}$ & Bendro skaičiaus \% \\
\hline 10 & 50 & 5 \\
\hline 9 & 100 & 10 \\
\hline 8 & 350 & 35 \\
\hline 7 & 300 & 30 \\
\hline 6 & 100 & 10 \\
\hline 5 & 100 & 10 \\
\hline Iš viso & 1000 & 100 \\
\hline
\end{tabular}

ECTS vertinimų lentelè nusako vertinimo skalès taikymo praktiką. Konvertuojant pažymius taikant ECTS vertinimų lentelę, vertinimai iš vienos studijų rezultatų vertinimo sistemos i kitą yra konvertuojami tiesiogiai, nenaudojant tarpinių vertinimų. Ši pažymių konvertavimo metodika yra parenkama pažymių konvertavimo modeliams sudaryti.

\subsection{Antrojo skyriaus išvados}

1. Mokymosi pasiekimų lygiui nustatyti aukštosiose mokyklose taikomas norminis, kriterinis ir standartais grịstas vertinimo modelis. Analizuojant ịvairių šalių studijų rezultatų vertinimo sistemas paaiškejjo, kad didžioji dalis aukštojo mokslo institucijų studijų rezultatams vertinti renkasi kriterinị vertinimo modelị. Rusų edukologas Š. K. Askerov studentų pasiekimų atitikimo apibrěžtiems kriterijams vertinti skiria tiesinị ir netiesinị vertinimo modelius.

2. Atlikta ịvairių šalių studijų rezultatų vertinimo sistemų analizè parodè, kad įvairiose šalyse pasiektiems studijų rezultatams vertinti taikomos studijų rezultatu vertinimo sistemos su skirtingomis vertinimo skalėmis. Skiriasi ne tik jų žymejjimas, dydis, teigiamų ir neigiamų vertinimų skaičius, bet ir jų taikymo praktika.

3. Studijų rezultatų vertinimo sistemų skirtumus sąlygoja ịvairių šalių pedagogikos ir kultūros tradicijų skirtumai. Istorinès aplinkybès inicijuoja studijų rezultatų vertinimo sistemų pokyčius. Bolonijos procesas yra vienas iš svarbiau- 
sių šiandieninès kaitos variklių, skatinančių taikomų studijų rezultatų vertinimo sistemų peržiūrą, atnaujinimą, pokyčius.

4. Sukurta vertinimų konvertavimo metodika - ECTS vertinimo skalè neužtikrina skirtingose šalyse, institucijose ar studijų kryptyse gautų įvertinimų palyginamumo, skaidrumo, teisingo interpretavimą. Skirtingas šios vertinimo skalès suvokimas daro įtaką netinkamam šios skalès taikymui.

5. Atlikus studijų rezultatų vertinimo sistemų analizę ir išnagrinejjus įvairias vertinimų konvertavimo metodikas, vertinimų konvertavimo modeliams sudaryti nutarta pasirinkti supaprastintą ECTS metodiką - ECTS vertinimų lentelę. 


\section{Pažymiu konvertavimo modeliai ir juos realizuojantys algoritmai}

Vertinimo skalių ir jų taikymo praktikų skirtumai sąlygoja pažymių konvertavimo algoritmizavimo būtinybę. Vertinimų konvertavimo problema analizuojama ịvairių autorių darbuose. Jau 1997 metais G. Haugas nagrinèdamas ịvairiose šalyse naudojamų vertinimo skalių skirtumus pabrěžè, kad vertinimų interpretavimas nèra objektyvesnis nei pats vertinimo procesas. Vertinimų konvertavimo problemiškumą lemia tiek naudojamų vertinimo skalių skirtumai, tiek skirtingos šių vertinimo skalių taikymo praktikos.

Didelio susidomejjimo susilaukè vertinimų konvertavimas į ECTS vertinimo skalę. S. Nunes, L. Ribeiro, G. David (2005) aprašè vertinimų konvertavimo ị ECTS vertinimo skalę metodą, išskirdami atskirus, Portugalijoje įteisintus konvertavimo atvejus. P. Warfvinge (2008) nagrinejjo pažymių konvertavimo ị ECTS vertinimo skalę būdus.

Tačiau vertinimų konvertavimas iš vienos studijų rezultatų vertinimo skalès i kitą išlieka aktualia ir neišspręsta problema. Todèl šiame skyriuje pristatomi sukurti vertinimų konvertavimo iš vienos studijų rezultatų vertinimo skalès i kitą modeliai, algoritmų schemomis aprašomi juos realizuojantys algoritmai. 


\subsection{Dviparametris pažymiụ konvertavimo modelis}

Kadangi įskaitomi tik teigiami studentų vertinimai, todèl neigiamų pažymių konvertavimas nèra prasmingas. Visiems neigiamiems besimokančiuju pažymiams turètų būti priskiriamas neigiamą pažymio reikšmę atspindintis apibūdinimas. Sudaromi pažymių konvertavimo modeliai yra skirti teigiamiems studentų vertinimams konvertuoti. Pirmasis sudarytas vertinimų konvertavimo modelis yra dviparametris. Konvertuojant vertinimus iš vienos studijų rezultatų vertinimo skalès ị kitą, šis modelis įvertina du parametrus - sukauptos kontrolinès pažymių aibès teigiamų pažymių pasiskirstymą vertinimo skalejje $A$ ir sukauptos kontrolinès pažymių aibès teigiamų pažymių pasiskirstymą vertinimo skalèje $B$. Šiuos parametrus pažymejję raidèmis $L, K$, pažymio $a_{i}$ vertinimo skalèje $A$ atitikmens $b_{j}$ priskyrimą vertinimo skalejje $B$ galima apibrèžti kaip dviparametrę funkciją.

$$
a_{i}=f\left(L, K, b_{j}\right) \quad i=\overline{1, n} \quad j=\overline{1, m}
$$

Sukauptų kontrolinès pažymių aibės teigiamų pažymių pasiskirstymas vertinimo skalèse $A$ ir $B$ aprašomas ECTS vertinimų lentelèmis. Vertinimų konvertavimas, taikant dviparametrị pažymių konvertavimo modelį, išskaidomas i tris pagrindinius etapus: tikimybinių skirstinių, atitinkančių vertinimų skalių $A$ ir $B$ ECTS vertinimų lenteles sudarymas; dvimačio tikimybinio skirstinio, vertinimų konvertavimo lentelès, suformavimas; pažymių atitikmenų priskyrimas (3.1 pav.). skales $A$ ir $B$, sudarymas

Dvimačio tikimybinio skirstinio, vertinimų konvertavimo lentelès, suformavimas 
3.1 pav. Vertinimų konvertavimo, taikant dviparametrị pažymių konvertavimo modeli, etapai

Fig. 3.1. Stages of the grade conversion according to the two-parameter grade conversion model

Vertinimų konvertavimo matematinis modelis sudaromas supaprastintos ECTS vertinimų konvertavimo metodikos - ECTS vertinimų lentelès pagrindu. Sudarytas pažymių konvertavimo modelis remiasi sukaupta teigiamų vertinimų pasiskirstymo statistika. Šis modelis taikytinas tiek norminių, tiek kriterinių vertinimo skalių pažymiams konvertuoti. Dviejų vertinimo skalių sąryšiai aprašomi žemiau pateikta ECTS vertinimų lentele.

3.1 lentelè. Vertinimo skalių $A$ ir $B$ saryšio lentelè

Table 3.1. The relation of grading scales $A$ and $B$

\begin{tabular}{|c|c|c|c|}
\hline $\begin{array}{c}\text { Vertinimo } \\
\text { skalè } A\end{array}$ & $\begin{array}{c}\text { Pažymių pasiskirstymas } \\
\text { vertinimo skalèje } A, \%\end{array}$ & $\begin{array}{c}\text { Vertinimo } \\
\text { skalè } B\end{array}$ & $\begin{array}{c}\text { Pažymiú pasiskirstymas } \\
\text { vertinimo skalèje } B, \%\end{array}$ \\
\hline$a_{1}$ & $k_{l}$ & $b_{1}$ & $l_{l}$ \\
\hline$a_{2}$ & $k_{2}$ & $b_{2}$ & $l_{2}$ \\
\hline$\ldots$ & $\ldots$ & $\ldots$ & $\ldots$ \\
\hline$a_{m}$ & $k_{m}$ & $b_{m}$ & \\
\hline$\ldots$ & $\ldots$ & & 100 \\
\hline$a_{n}$ & $k_{n}$ & & \\
\hline Iš viso & 100 & & \\
\hline
\end{tabular}

Šioje lentelèje $a_{l}, a_{2}, \ldots, a_{n}$ žymi $A$ vertinimo skalès teigiamus pažymius, o $b_{l}$, $b_{2}, \ldots, b_{m}-B$ vertinimo skalès teigiamus pažymius. Vertinimo skalių pažymiai pateikiami nuo didžiausio iki mažiausio. Sių skalių dydžiai aprašomi indeksais $n$ ir $m$. Šie indeksai tenkina (3.2) nelygybėmis aprašytus sąryšius:

$$
n \geq 1, m \geq 1
$$

Vertinimo skalių $A$ ir $B$ duomenys užrašomi kaip tikimybiniai skirstiniai. Kadangi vienose šalyse naudojamos didejjančios vertinimų skalès, o kitose mažèjančios taip pat skiriasi šių vertinimo skalių žymėjimai, îvedami nauji kintamieji - vertinimų indeksai $i, j$. Vertinimų indeksai sunumeruoja skalių pažymius mažejimo tvarka ir atitinka nagrinėjamų skirstinių požymio reikšmes. Skirstinių požymio reikšmès - tai iš eilès einantys natūriniai skaičiai. Sudaromų tikimybinių skirstinių reikšmių igijimo tikimybès apskaičiuojamos taikant (3.3) formules.

$$
p_{A i}=\frac{k_{i}}{100}, \quad i=\overline{1, n}, \quad p_{B j}=\frac{l_{j}}{100}, j=\overline{1, m}
$$


Vertinimams konvertuoti iš vertinimo skalès $A$ i vertinimo skalę $B$ sudaromas dvimatis tikimybinis skirstinys (3.2 lentelè). Šio skirstinio igyjamos reikšmès $(i, j), i=\overline{1, n}, j=\overline{1, m}$. Skirstinio reikšmès $(i, j)$ igijimo tikimybe $p_{i j}$ yra tikimybè, kad studento žinios ir gebejjimai vertinimo skalejje $A$ įvertinti pažymiu su indeksu $i, B$ vertinimų skalëje bus įvertinti pažymiu su indeksu $j$.

3.2 lentelè. Vertinimų konvertavimo dvimatis tikimybinis skirstinys

Table 3.2. Two-dimensional probability decomposition of grades conversion

\begin{tabular}{|c|c|c|c|c|}
\hline $\mathrm{A}-\mathrm{B}$ & 1 & 2 & $\ldots$ & $\mathrm{m}$ \\
\hline 1 & $p_{11}$ & $p_{12}$ & $\ldots$ & $p_{1 m}$ \\
\hline 2 & $p_{21}$ & $p_{22}$ & $\ldots$ & $P_{2 m}$ \\
\hline$\ldots$ & $\ldots$ & $\ldots$ & $\ldots$ & $\ldots$ \\
\hline $\mathrm{n}$ & $p_{n 1}$ & $p_{n 2}$ & $\ldots$ & $p_{n m}$ \\
\hline
\end{tabular}

Dvimačio tikimybinio skirstinio tikimybès apskaičiuojamos taikant (3.4) formulę:

$$
\begin{aligned}
& p_{i j}=\min \left(p_{A i}-\sum_{k=0}^{j-1} p_{i k} ; p_{B j}-\sum_{k=0}^{i-1} p_{k j}\right), \quad i=\overline{1, n}, \quad j=\overline{1, m} \\
& p_{i 0}=0, p_{0 j}=0
\end{aligned}
$$

Teigiamo pažymio atitikmuo yra priskiriamas sudaryto dvimačio tikimybinio skirstinio pagrindu. Jei vertinimai nèra reitinguojami, tuomet pažymiui priskiriamas labiausiai tikètinas atitikmuo.

$$
a_{i}=b_{k}, \text { jei } p_{i k}=\max \left(p_{i 1}, p_{i 2}, \ldots, p_{i m}\right), i=\overline{1, n}
$$

Jei kelių pažymių igijimo tikimybės yra lygios, tuomet imamas maksimalus vertinimo atitikmuo, t. y. pažymys su mažiausiu vertinimo indeksu. Pažymi $a_{i}$ vertinimo skalejje $A$, atitinka pažymys $b_{k}$ vertinimo skalejje $B$, jei skirstinio reikšmės $(i, k)$ pasirodymo tikimybė tenkina (3.6) lygybėmis aprašytus sąryšius.

$$
\begin{aligned}
& a_{i}=b_{k}, \text { jei } p_{i k}=\max \left(p_{i 1}, p_{i 2}, \ldots, p_{i m}\right), \\
& \text { jei } p_{i k}=p_{i l}, \text { tai } k<l, i=\overline{1, n}
\end{aligned}
$$

Jei studentai yra reitinguojami, tuomet pažymiai surūšiuojami vertinimo reikšmés mažejimo tvarka ir kiekvienam vertinimui priskiriamas ji atitinkantis reitingas. Konvertuojamą pažymį $a_{i}$ atitinkančių vertinimų skaičius $s k_{i}$ perskirstomas taikant (3.7) formulę. Vertinimą $b_{I}$ atitinka $s_{i l}$ aukščiausių $a_{i}$ vertinimų, $b_{2}$ - $s_{i 2}$ po jų einančių $a_{i}$ vertinimų ir t. t. 


$$
\begin{aligned}
& s_{i j}=\left[\sum_{k=1}^{j} \frac{p_{i k}}{\sum_{l=1}^{m} p_{i l}} * s k_{i}+0,5\right]-\sum_{k=0}^{j-1} s_{i k} i=\overline{1, n}, j=\overline{1, m}, \\
& s_{i 0}=0
\end{aligned}
$$

Jei konvertuojamo pažymio $a_{i}$ reitingas analizuojamoje ịvertinimų aibejje yra $r$, vertinimo reitingas $a_{i}$ pažymių grupeje $v$, tuomet ši reitingą atitinkančių vertinimų skaičius $r s k_{r}$, perskirstomas taikant (3.8) formulę. Vertinimą $b_{1}$ atitinka $c_{r 1}^{i}$ aukščiausių reitingo $r$ vertinimų, $b_{2}-c_{r 2}^{i}$ po jų einančių reitingo $r$ vertinimų ir t. t.

$$
\begin{aligned}
& c_{r j}^{i}=\min \left(s_{i j}-\sum_{k=0}^{v-1} c_{k j}^{i} ; r s k_{r}-\sum_{k=0}^{j-1} c_{r k}^{i}\right), \quad i=\overline{1, n}, \quad j=\overline{1, m} \\
& c_{0 j}^{i}=0, c_{r 0}^{i}=0
\end{aligned}
$$

Tuomet reitingo $r$ pažymi $a_{i}$ atitinka pažymys $b_{k}$ vertinimų skaleje $B$, jei tenkinami (3.9) lygybe aprašyti sąryšiai.

$$
\begin{aligned}
& a_{i}=b_{k}, \text { jei } c_{r k}^{i}=\max \left(c_{r 1}^{i}, c_{r 2}^{i}, \ldots, c_{r m}^{i}\right), \quad i=\overline{1, n}, k=\overline{1, m} \\
& \text { jei } c_{r k}^{i}=c_{r l}^{i}, \text { tai } k<l
\end{aligned}
$$

Dviparametris pažymių konvertavimo modelis teigiamus pažymius konvertuoja labiausiai tikètino vertinimo atitikmens principu, ịvertindamas pažymio reitingą analizuojamų pažymių grupeje. Jei vertinimai nèra reitinguojami, tuomet priskiriamas atitikmuo su maksimalia pasirodymo tikimybe. Jei kelių pažymių tikimybių reikšmès yra lygios, tuomet imamas maksimalus pažymys, t. y. pažymys su mažesniu vertinimo skalès indeksu. Reitinguojamoje pažymių aibejje ieškomas vertinimo atitikmuo, kuriam yra priskiriamas didžiausias šio reitingo vertinimu skaičius. Jei keliems atitikmenims yra priskiriamas vienodas vertinimų skaičius, tuomet imamas maksimalus pažymys, t. y. pažymys su mažesniu vertinimo skalès indeksu.

\subsection{Dviparametrị pažymių konvertavimo modelị realizuojantis algoritmas}

Šiame skyrelyje algoritmų schemomis aprašomas dviparametrị pažymių konvertavimo modeli realizuojantis algoritmas. Kadangi šis pažymių konvertavimo modelis skaidomas $\mathfrak{i}$ tris etapus, aprašomas algoritmas skaidomas $\mathfrak{i}$ tris dalis. Pirmoji algoritmo dalis skirta pradiniams duomenims nuskaityti, tikimybiniams 
skirstiniams, atitinkantiems vertinimo skales $A$ ir $B$, sudaryti. Pradinius algoritmo duomenis sudaro sukaupti vertinimo skalių $A$ ir $B$ teigiamų pažymių pasiskirstymo duomenys bei konvertuojamos pažymių aibès duomenys. 3.2 paveiksle pateikta pirmosios algoritmo dalies schema.

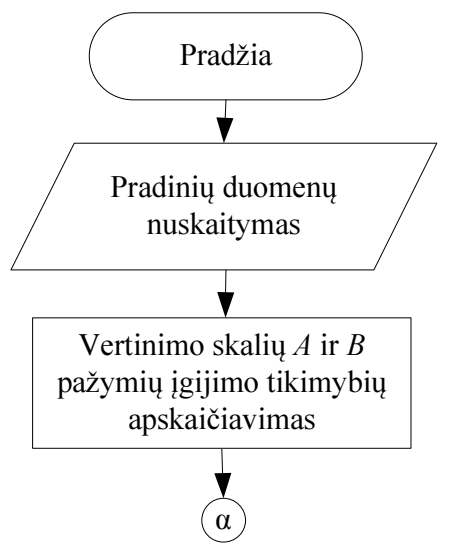

3.2 pav. Dviparametrio vertinimų konvertavimo modelio algoritmo 1-a dalis Fig. 3.2. Part 1 of the algorithm for the two-parameter grade conversion model

Antroji algoritmo dalis skirta vertinimų konvertavimo lentelei suformuoti (3.3 pav.).

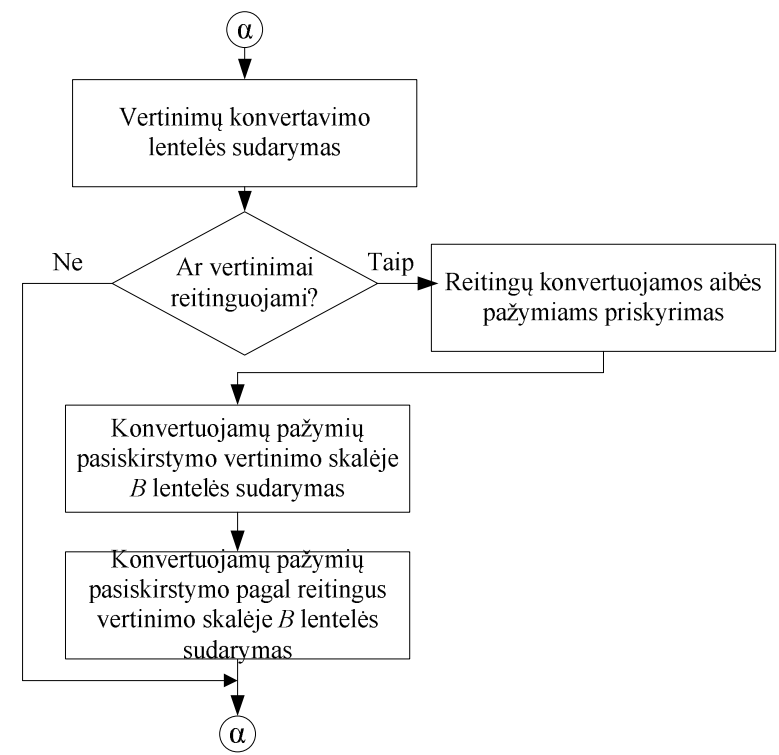

3.3 pav. Dviparametrio vertinimų konvertavimo modelio algoritmo 2 -a dalis

Fig. 3.3. Part 2 of the algorithm for the two-parameter grade conversion model 
Jei konvertuojami pažymiai yra reitinguojami, tuomet sudaromos konvertuojamų pažymių pasiskirstymo vertinimo skaleje $B$ ir konvertuojamų pažymių pasiskirstymo pagal reitingus vertinimo skaleje $B$ lentelès. Ši algoritmo dalis tai parengiamasis etapas konvertuojamų teigiamų vertinimų atitikmenims priskirti.

Trečioji algoritmo dalis skirta vertinimų atitikmenų priskyrimui ir išvedimui. Tai baigiamoji algoritmo dalis. Kadangi konvertuojant pažymius iš vienos studijų rezultatų vertinimo skalès ị kitą skiriami reitinguojamos ir nereitinguojamos pažymių aibès konvertavimo atvejai, todèl algoritmas šakojasi ị dvi šakas (3.4 pav.). Jei konvertuojama pažymių aibè nèra reitinguojama, tuomet konvertuojamiems teigiamiems pažymiams priskiriami labiausiai tikètini atitikmenys, t. y. tokie atitikmenys, kurių pasirodymo tikimybès yra maksimalios. Jei kelių atitikmenų pasirodymo tikimybès yra maksimalios, tuomet priskiriamas pažymys su minimaliu vertinimo skalès indeksu.

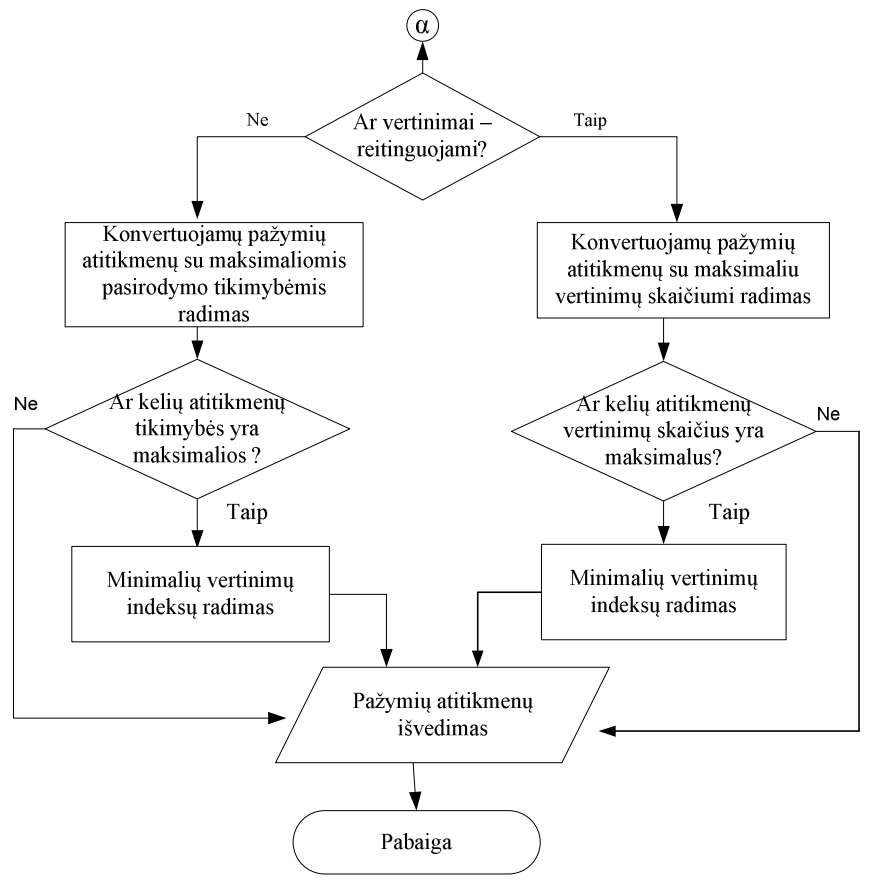

3.4 pav. Dviparametrio vertinimų konvertavimo modelio algoritmo 3-a dalis

Fig. 3.4. Part 3 of the algorithm for the two-parameter grade conversion model

Reitinguojamoje pažymių aibejje vertinimų atitikmenys priskiriami konvertuojamų pažymių pasiskirstymo pagal reitingus vertinimo skalèje $B$ lentelès pagrindu. Konvertuojamam teigiamam pažymiui priskiriamas toks vertinimo skalès $B$ atitikmuo, kurị atitinka didžiausias šio reitingo pažymių skaičius. Jei kelių 
atitikmenų vertinimų skaičius yra maksimalus, tuomet parenkamas pažymys su minimaliu vertinimo skalès indeksu.

\subsection{Triparametris pažymiụ konvertavimo modelis}

Antrasis pažymių konvertavimo modelis yra triparametris. Triparametris pažymių konvertavimo modelis yra skirtas teigiamiems studentu vertinimams konvertuoti. Šis modelis ịvertina tris parametrus: sukauptos kontrolinès pažymių aibès teigiamų duomenų pasiskirstymą vertinimo skalëje $A$, sukauptos kontrolinès pažymių aibès teigiamų duomenų pasiskirstymą vertinimo skaleje $B$ ir konvertuojamos pažymių aibės teigiamų duomenų pasiskirstymą. Šiuos parametrus pažymèję raidèmis $L, K, P$ pažymio $a_{i}$ vertinimo skalëje $A$ atitikmens $b_{j}$ priskyrimą vertinimo skalèje $B$, galima apibrèžti kaip triparametrę funkciją.

$$
a_{i}=f\left(L, K, P, b_{j}\right) \quad i=\overline{1, n} \quad j=\overline{1, m}
$$

Vertinimų konvertavimas, taikant triparametrị pažymių konvertavimo modeli, išskaidomas ị keturis pagrindinius etapus (3.5 pav.).

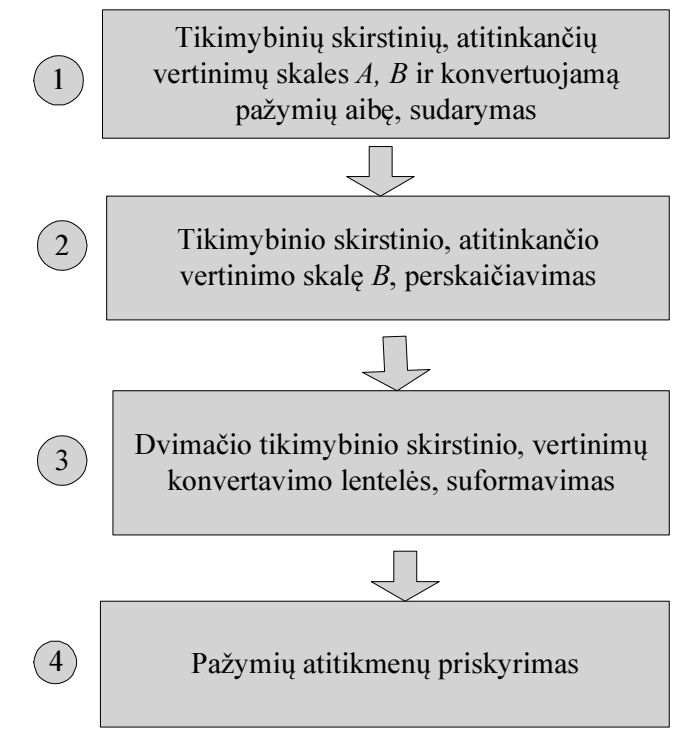

3.5 pav. Vertinimų konvertavimo, taikant triparametri pažymių konvertavimo modeli, etapai

Fig. 3.5. Stages of the conversion of grades with the application of the threeparameter grade conversion model 
Triparametrio pažymių konvertavimo modelio etapai apima: tikimybinių skirstinių, atitinkančių vertinimų skalių $A$ ir $B$ ECTS vertinimų lenteles ir konvertuojamą pažymių aibę, sudarymas; tikimybinio skirstinio, atitinkančio vertinimo skalę $B$, reikšmių igijimo tikimybių perskaičiavimas; dvimačio tikimybinio skirstinio, vertinimų konvertavimo lentelès, suformavimas; pažymių atitikmenų priskyrimas

Triparametriu pažymių konvertavimo modeliu vertinimai konvertuojami, ịvertinus konvertuojamos pažymių aibės teigiamų pažymių pasiskirstymą. Kaip ir pirmasis modelis, jis taikytinas tiek norminių, tiek kriterinių vertinimo skalių pažymiams konvertuoti. Konvertuojamos teigiamų pažymių aibẻs duomenys aprašyti žemiau pateiktoje lentelejje. Vertinimo indeksas sunumeruoja teigiamus skalès pažymius mažejimo tvarka. Šioje pažymių aibejje vertinimas $a_{l}$ pasikartoja $d_{1}$ kartą, $a_{2}-d_{2}$ kartus, o pažymiu $a_{n}$ buvo ịvertinta $d_{n}$ studentų.

3.3 lentelè. Konvertuojamos pažymių aibės teigiamų pažymių pasiskirstymas

Table 3.3. Distribution of the convertible sets of positive grades

\begin{tabular}{|c|c|c|}
\hline Vertinimas & $\begin{array}{c}\text { Skirstinio požymio reikšmės } \\
\text { (vertinimo indeksas) }\end{array}$ & Vertinimų skaičius \\
\hline & 0 & 0 \\
\hline$a_{1}$ & 1 & $d_{1}$ \\
\hline$a_{2}$ & 2 & $d_{2}$ \\
\hline$\ldots$ & $\ldots$ & $\ldots$ \\
\hline$a_{n}$ & $\mathrm{n}$ & $d_{n}$ \\
\hline
\end{tabular}

Tarkime analizuojamą pažymių aibę sudaro $d$ teigiamų vertinimų. Tuomet yra tenkinamas (3.11) formule aprašytas sąryšis.

$$
\sum_{i=1}^{n} d_{i}=d
$$

Konvertuojamos pažymių aibès duomenys užrašomi tikimybiniu skirstiniu. Šio skirstinio reikšmių igijimo tikimybès $p_{N i}, i=\overline{1, n}$ apskaičiuojamos, taikant (3.12) formulę.

$$
p_{N i}=\frac{d_{i}}{d}, \quad i=\overline{1, n}
$$

Tikimybinis skirstinys papildomas skirstinio požymio reikšmes atitinkančiais kvantiliais $Q_{N i}, i=\overline{1, n} \cdot Q_{N p}$ lygmens kvantilis yra pažymio su indeksu 
mažesniu arba lygaus $p$ pasirodymo tikimybè. Kvantiliams skaičiuoti taikoma (3.13) formulè.

$$
Q_{N i}=\sum_{k=1}^{i} p_{N k}, \quad i=\overline{1, n}
$$

Tikimybinio skirstinio duomenys aprašyti žemiau pateiktoje lentelejje. Šioje lentelèje $a_{1}, a_{2}, \ldots, a_{n}$ žymi $A$ vertinimo skalès teigiamus pažymius. Vertinimo skalès teigiamus pažymius mažèjimo tvarka sunumeruoja vertinimo indeksas. Vertinimo indeksas atitinka sudaryto skirstinio požymio reikšmes. Skirstinio požymio reikšmėms apskaičiuojamos tikimybès $p_{N i}, i=\overline{1, n}$ ir kvantiliai $Q_{N i}, i=\overline{1, n}(3.4$ lentelè).

3.4 lentelè. Tikimybinis skirstinys, atitinkantis konvertuojamos pažymių aibės duomenis Table 3.4. Probability distribution corresponding the data of convertible grades sets

\begin{tabular}{|c|c|c|c|}
\hline Vertinimas & $\begin{array}{c}\text { Skirstinio požymio } \\
\text { reikšmės (vertinimo } \\
\text { indeksas) }\end{array}$ & $\begin{array}{c}\text { Reikšmės igijimo } \\
\text { tikimybe }\end{array}$ & Kvantilis \\
\hline & 0 & 0 & 0 \\
\hline$a_{1}$ & 1 & $p_{N 1}$ & $Q_{N 1}$ \\
\hline$a_{2}$ & 2 & $p_{N 2}$ & $Q_{N 2}$ \\
\hline$\ldots$ & $\ldots$ & $\ldots$ & $\ldots$ \\
\hline$a_{n}$ & $\mathrm{n}$ & $P_{N n}$ & $Q_{N n}$ \\
\hline
\end{tabular}

Kaip ir dviparametrio modelio atveju, sudaromi vertinimo skaliu $A$ ir $B$ ECTS lenteles atitinkantys tikimybiniai skirstiniai. Šių skirstinių reikšmių igijimo tikimybès apskaičiuojamos taikant (3.3) formules. Sudaryti skirstiniai papildomi skirstinio požymio reikšmes atitinkančiais kvantiliais $Q_{A i}, i=\overline{1, n}$ ir $Q_{B j}, j=\overline{1, m}$. Kvantiliams skaičiuoti taikoma (3.14) formulè.

$$
Q_{A i}=\sum_{k=1}^{i} p_{A k}, \quad i=\overline{1, n} Q_{B j}=\sum_{k=1}^{j} p_{B k}, \quad j=\overline{1, m}
$$

Tikimybini skirstini visiškai nusako jo pasiskirstymo funkcija. Atsitiktinio dydžio $X$ pasiskirstymo funkcija $F(x)$ apibrěžiama (3.15) lygybe. Pasiskirstymo funkcijos reikšmė taške x yra lygi tikimybei, kad atsitiktinis dydis $X$ igis reikšmę nedidesnę nei $x$.

$$
F(x)=P(X \leq x)
$$


Reitinguojamos pažymių aibès vertinimų indeksai yra realieji skaičiai, priklausantys intervalui $[0 ; n]$. Taigi, konvertuojant reitinguojamos teigiamų pažymių aibès duomenis, turime tolydųji skirstinị su jị nusakančia tolydžiaja pasiskirstymo funkcija. Tikimybinių skirstinių, atitinkančių kontrolinès ir konvertuojamos teigiamų pažymių aibès duomenis, pasiskirstymo funkcijų $F_{A}(x), F_{N}(x)$ grafikai pateikti (3.6) paveiksle. Pasiskirstymo funkcijos $F_{A}(x)$ ir $F_{N}(x)$ yra didejjančios. Didesnį vertinimo skalès $A$ indeksą atitinka didesnè pasiskirstymo funkcijų $F_{A}(x)$ ir $F_{N}(x)$ reikšmè. Šios funkcijos maksimalią reikšmę igyja taške $n$, kuris atitinka maksimalų vertinimo skalès A indeksą.

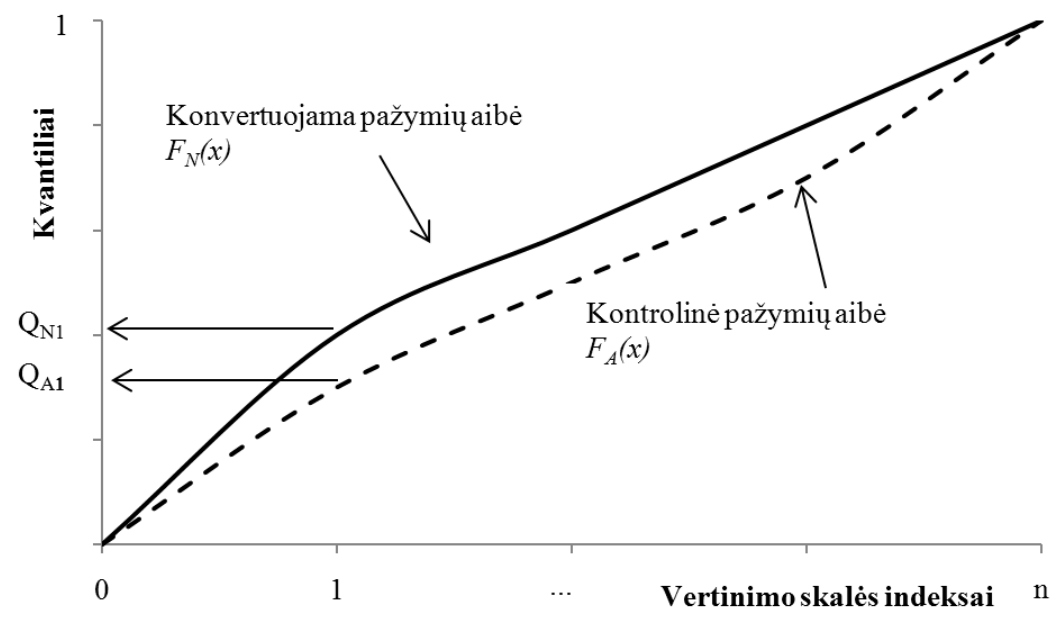

3.6 pav. Skirstinių pasiskirstymo funkcijų grafikai

Fig. 3.6. Graphs of distribution functions of the distribution

Tikimybinio skirstinio, atitinkančio vertinimo skalès $A$ kontrolinès teigiamų pažymių aibès duomenis, pasiskirstymo funkcijos $F_{A}(x)$ reikšmès taškuose $x_{A i}=i, i=\overline{1, n}$ yra lygios atitinkamiems kontrolinès pažymių aibès skirstinio kvantiliams.

$$
F_{A}\left(x_{A i}\right)=Q_{A i}, \quad i=\overline{1, n}
$$

Skirstinio, atitinkančio vertinimo skalès $A$ konvertuojamos teigiamų pažymių aibès duomenis, pasiskirstymo funkcijos $F_{N}(x)$ reikšmès taškuose $x_{A i}=i, i=\overline{1, n}$ yra lygios atitinkamiems konvertuojamos pažymių aibès skirstinio kvantiliams.

$$
F_{N}\left(x_{A i}\right)=Q_{N i}, \quad i=\overline{1, n}
$$


Konvertuojant pažymius iš vertinimo skalès $A$ ị vertinimo skalę $B$, ieškomos vertinimo skalès $A$ indeksų reikšmès $x_{B j}, j=\overline{1, m}$ su kuriomis pasiskirstymo funkcija $F_{A}(x)$ tenkina (3.18) formulèmis aprašytus sąryšius.

$$
F_{A}\left(x_{B j}\right)=Q_{B j}, \quad j=\overline{1, m}
$$

Šie vertinimo skalès indeksai susieja konvertuojamą teigiamų pažymių aibę su sukauptos teigiamų pažymių aibės duomenimis. Sukauptos teigiamų pažymių aibės duomenys rodo vertinimo skalès taikymo praktiką, t. y. kaip šioje studijų programoje yra vertinami studentai, kokie vertinimo skalès pažymiai yra naudojami.

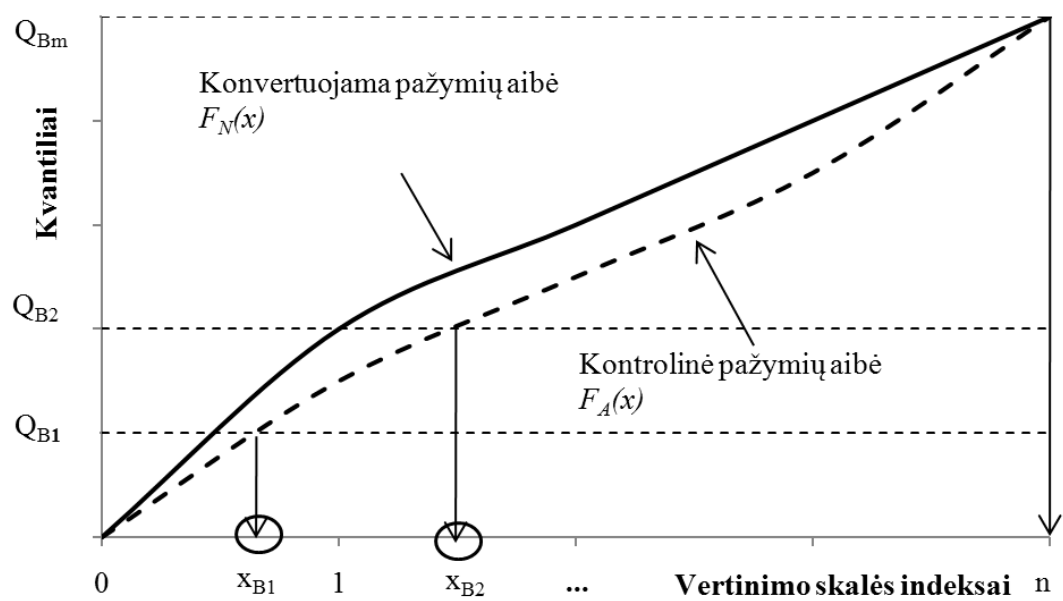

3.7 pav. Vertinimo skalès $A$ indeksai, atitinkantys kvantilius $Q_{B j}, j=\overline{1, m}$

Fig. 3.7. Grading scale $A$ indexes, corresponding quantile $Q_{B j}, j=\overline{1, m}$

Kadangi nėra žinoma tiksli pasiskirstymo funkcijos $F_{A}(x)$ išraiška, todèl kvantilius $Q_{B j}, j=\overline{1, m}$ atitinkantiems vertinimo indeksams $x_{B j}, j=\overline{1, m}$ apskaičiuoti taikomas empirinių kvantilių metodas (3.19).

$$
\begin{aligned}
& x_{B j}=\frac{Q_{B j}-i \cdot F_{A}\left(x_{A i-1}\right)+(i-1) \cdot F_{A}\left(x_{A i}\right)}{F_{A}\left(x_{A i}\right)-F_{A}\left(x_{A i-1}\right)}, \\
& \operatorname{kur} F_{A}\left(x_{A i-1}\right)<P\left(X \leq x_{B j}\right)<F_{A}\left(x_{A i}\right), \quad i=\overline{1, n}, \quad j=\overline{1, m}
\end{aligned}
$$


Susiejant konvertuojamą teigiamų pažymių aibę su kontrolinès aibės duomenimis, apskaičiuojami naujieji kvantiliai $Q_{B N j}, j=\overline{1, m}$, atitinkantys apskaičiuotas vertinimų indeksų reikšmes $x_{B j}, j=\overline{1, m}$ (3.8 pav.).

Naujiesiems kvantiliams $Q_{B N j}, j=\overline{1, m}$ apskaičiuoti taikoma (3.20) formulè. Ši formulè gaunama pertvarkant (3.19) formulę.

$$
\begin{aligned}
& Q_{B N j}=x_{B j} \cdot\left(F_{N}\left(x_{A i}\right)-F_{N}\left(x_{A i-1}\right)\right)+i \cdot F_{N}\left(x_{A i-1}\right)-(i-1) \cdot F_{N}\left(x_{A i}\right), \\
& \operatorname{kur} x_{A i-1}<x_{B j}<x_{A i}, \quad i=\overline{1, n} j=\overline{1, m}
\end{aligned}
$$

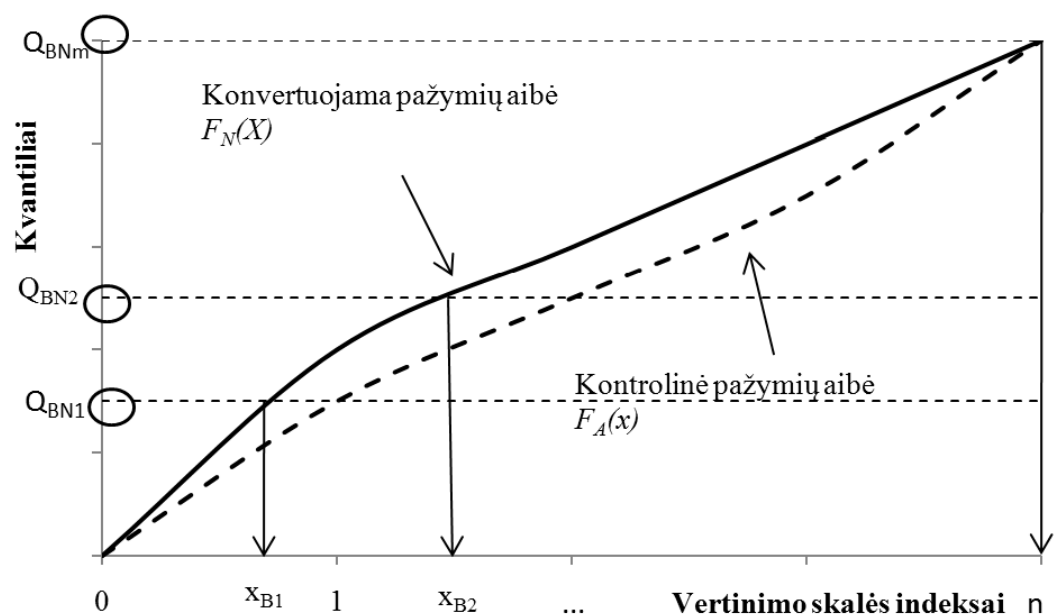

3.8 pav. Naujieji konvertuojamos pažymių aibès kvantiliai $Q_{B N j}, j=\overline{1, m}$

Fig. 3.8. The new quantiles of convertible grade sets $Q_{B N j}, j=\overline{1, m}$

Kaip ir pirmojo modelio atveju, pažymiams konvertuoti iš vertinimo skalès $A$ i vertinimo skalę $B$ sudaromas dvimatis tikimybinis skirstinys - vertinimų konvertavimo lentelè (3.21).

$$
p_{i j}=P\left(X=x_{i}, Y=y_{j}\right), \quad i=\overline{1, n}, \quad j=\overline{1, m}
$$

Dvimačiui tikimybiniam skirstiniui sudaryti apskaičiuojamos kvantilius $Q_{B N j}, j=\overline{1, m}$ atitinkančių tikimybių reikšmès $p_{B N j}, j=\overline{1, m}(3.22)$.

$$
\begin{aligned}
& p_{B N j}=Q_{B N j}-Q_{B N j-1}, \quad j=\overline{1, m} \\
& Q_{B N 0}=0
\end{aligned}
$$


Dvimačio tikimybinio skirstinio, atitinkančio vertinimų konvertavimo lentelę, tikimybės apskaičiuojamos taikant (3.23) formulę.

$$
\begin{aligned}
& p_{i j}=\min \left(p_{N i}-\sum_{k=0}^{j-1} p_{B N k} ; p_{B N j}-\sum_{k=0}^{i-1} p_{N k}\right), \quad i=\overline{1, n}, \quad j=\overline{1, m} \\
& p_{B N 0}=0, p_{N 0}=0
\end{aligned}
$$

Pažymio atitikmens priskyrimas triparametrio pažymių konvertavimo modelio atveju yra analogiškas, kaip ir taikant dviparametrị pažymių konvertavimo modelị. Jei vertinimai nèra reitinguojami, tuomet teigiamam pažymiui priskiriamas labiausiai tikètinas atitikmuo, taikant anksčiau aprašytą (3.5) formulę. Jei kelių pažymių igijimo tikimybès yra lygios, tuomet imamas maksimalus vertinimo atitikmuo, t. y. pažymys su mažiausiu vertinimo skalès indeksu (3.6).

Analogiškas ir pažymio atitikmens priskyrimas reitinguojamoje pažymių aibejje. Pažymio atitikmens priskyrimui reitinguojamoje vertinimų aibejje triparametrio pažymių konvertavimo modelio atveju taikoma (3.9) formulè.

\subsection{Triparametrị pažymiụ konvertavimo modelị realizuojantis algoritmas}

Šiame skyrelyje algoritmų schemomis aprašomas triparametri pažymių konvertavimo modelį realizuojantis algoritmas. Šis pažymių konvertavimo modelis skaidomas i keturis etapus, taigi aprašomas algoritmas skaidomas i keturias dalis. Skirtingai nuo dviparametrio pažymių konvertavimo modelio algoritmo, triparametrio pažymių konvertavimo modelio algoritmas papildomas tik šiam modeliui būtina algoritmo dalimi. Ši algoritmo dalis apima vertinimo skalès $A$, vertinimo skalès $B$ ir konvertuojamos teigiamų pažymių aibės tikimybinių skirstinių kvantilių apskaičiavimą; vertinimo skalès $B$ tikimybinio skirstinio kvantilių ir tikimybių perskaičiavimą (3.9. pav.). 


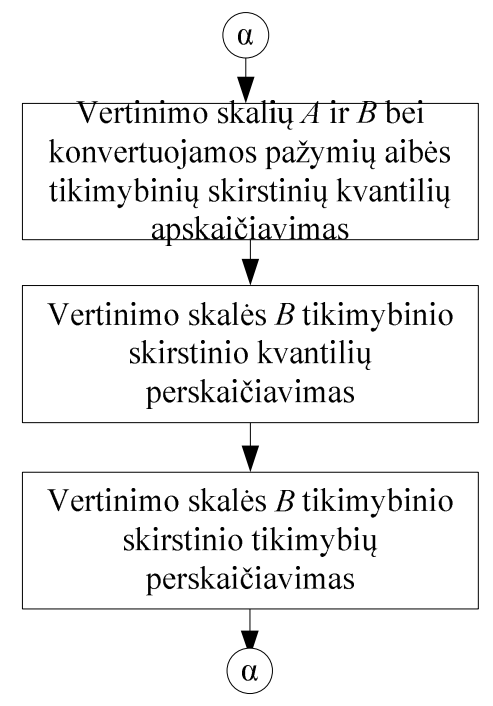

3.9 pav. Triparametrio vertinimų konvertavimo modelio algoritmo 2 -a dalis

Fig. 3.9. The second part of the three-parameter grades conversion model algorithm

Pirmoji algoritmo dalis, papildant ją konvertuojamos teigiamų pažymių aibės tikimybinio skirstinio sudarymo veiksmais, atitinka dviparametrio pažymių konvertavimo modelio pirmąją dalị. Trečioji ir ketvirtoji triparametrio pažymių konvertavimo modelio algoritmo dalys atitinka dviparametrio pažymių konvertavimo algoritmo antrają ir trečiają dalis. Taigi pirmoji triparametrio pažymių konvertavimo algoritmo dalis skirta pradiniams duomenims nuskaityti, tikimybiniams skirstiniams, atitinkantiems vertinimo skales $A, B$ ir konvertuojamą teigiamų pažymių aibę, sudaryti. Trečiojoje algoritmo dalyje suformuojama vertinimų konvertavimo lentelè. Jei konvertuojami pažymiai yra reitinguojami, tuomet sudaroma konvertuojamų teigiamų pažymių pasiskirstymo pagal reitingus vertinimo skaleje $B$ lentelè. Baigiamoji algoritmo dalis skirta vertinimu atitikmenims priskirti ir išvesti.

\subsection{Pažymių konvertavimo algoritmų sudėtingumo vertinimas}

Dviparametris ir triparametris pažymių konvertavimo algoritmas skiriasi pažymių konvertavimo lentelès sudarymo principais. Todèl lyginant šių dviejų algoritmų sudėtingumą, vertinama pažymių konvertavimo lentelès formavimo dalis.

Pradinių duomenų skaičius yra labai svarbi uždavinio charakteristika (Čiegis 2007). Dviparametrio pažymių konvertavimo modelio atveju vertinimo kon- 
vertavimo lentelès suformavimo algoritmo pradinius duomenis sudaro: $n$ duomenų, nusakančių vertinimo skalès $A$ teigiamų pažymių pasiskirstymą, $m$ duomenų, nusakančių vertinimo skalès $B$ teigiamų pažymių pasiskirstymą. Taigi bendras pažymių konvertavimo lentelès sudarymo algoritmo duomenų skaičius: $n+m$. Duomenų skaičius charakterizuoja uždavinio dydị, tačiau vien tik šis skaičius dar neapibūdina algoritmo sudètingumo (Čiegis 2007). Algoritmo sudètingumas apibrèžiamas kaip bazinių veiksmų skaičius (Čiegis 2007). Taigi, vertindami dviparametrio pažymių konvertavimo modelio, pažymių konvertavimo lentelès suformavimo algoritmo sudètingumą, turime apskaičiuoti atliekamų operacijų skaičių arba bent svarbiausią jų dali. Sudarant pažymių konvertavimo lentelę, atliekama $n m$ lyginimo ir $n+m$ atimties operacijų. Taigi dviparametrio pažymių konvertavimo modelio, vertinimų konvertavimo lentelès suformavimo algoritmo sudètingumas apskaičiuojamas, taikant (3.24) formulę.

$$
T(n+m)=n m+n+m
$$

Triparametrio pažymių konvertavimo modelio atveju, pažymių konvertavimo lentelès suformavimo uždavinys papildomas dviem pagalbiniais uždaviniais: sudarytų skirstinių kvantilių apskaičiavimo uždaviniu bei vertinimo skalę $B$ atitinkančio skirstinio kvantilių ir tikimybių perskaičiavimo uždaviniu. Šie papildomi uždaviniai $\mathrm{C}++$ kalboje realizuojami atskiromis funkcijomis. Skirstinių kvantilių apskaičiavimo uždavinio pradinių duomenų skaičius: $2 n+m$. Vertinimo skalę $B$ atitinkančio skirstinio kvantilių ir tikimybių perskaičiavimo uždavinio pradinių duomenų skaičius: $2 n$. Skirstinių kvantilių apskaičiavimo uždavinio sudètingumą pažymėję $T_{l}(2 n+m)$, vertinimo skalę $B$ atitinkančio skirstinio kvantilių ir tikimybių perskaičiavimo uždavinio sudètingumą pažymèję $T_{2}(2 n)$, gaunama (3.25) lygybe aprašyta triparametrio pažymių konvertavimo modelio, vertinimų konvertavimo lentelès suformavimo algoritmo sudètingumo $T_{N}(n+m)$ išraiška.

$$
T_{N}(n+m)=T(n+m)+T_{1}(2 n+m)+T_{2}(2 n)
$$

Taigi (3.25) lygybe aprašyti sąryšiai rodo, kad triparametrio pažymių konvertavimo modelio atveju vertinimų konvertavimo lentelès sudarymo algoritmas yra sudètingesnis nei dviparametrio pažymių konvertavimo modelio atveju.

Tęsiant analizę, vertinamas kiekvieno pagalbinio uždavinio sudètingumas. Apskaičiuojant sudarytų skirstinių kvantilius atliekama: $2 n+m$ sumavimo operacijų. Taigi sudarytų skirstinių kvantilių apskaičiavimo uždavinio algoritmo sudètingumas yra apskaičiuojamas, taikant (3.26) formulę.

$$
T_{1}(2 n+m) \approx 2 n+m
$$


Perskaičiuojant vertinimo skalès $B$ skirstinio kvantilius ir tikimybes atliekama $n m$ lyginimų ir 2(m-1) atimties ir daugybos operacijų. Taigi šio uždavinio algoritmo sudètingumas apskaičiuojamas, taikant (3.27) formulę.

$$
T_{2}(n+m) \approx n m+2(m-1)
$$

Iš lygybių (3.25), (3.26), (3.27) gauname, triparametrio pažymių konvertavimo modelio vertinimų konvertavimo lentelès sudarymo algoritmo sudètingumo vertinimą (3.28).

$$
T_{N}(n+m) \approx 2 n m+3 n+4 m-2
$$

Iš lygybių (3.24), (3.28) gauname, kad triparametrio pažymių konvertavimo modelio algoritmas yra daugiau nei 2 kartus sudètingesnis nei dviparametrio pažymių konvertavimo modelio algoritmas.

\subsection{Trečiojo skyriaus išvados}

1. Ivvertinus pažymių konvertavimo iš vienos studijų rezultatų vertinimo skalès ị kitą problemiškumą, sukurti du vertinimų konvertavimo modeliai skirti teigiamiems pažymiams konvertuoti. Pirmasis pažymių konvertavimo modelis yra dviparametris, antrasis teigiamus vertinimus konvertuoja įvertindamas tris parametrus.

2. Dviparametris pažymių konvertavimo modelis ịvertina du parametrus sukauptos kontrolinès pažymių aibès teigiamų pažymių pasiskirstymą vertinimo skalèje $A$ ir sukauptos kontrolinès pažymių aibès teigiamų pažymių pasiskirstymą vertinimo skalejje $B$. Triparametris pažymių konvertavimo modelis ịvertina dar vieną parametrą - konvertuojamos pažymių aibès teigiamų pažymių pasiskirstymą.

3. Dviparametris pažymių konvertavimo modelis sudarytas vertinimų skales atitinkančių ECTS vertinimų lentelių pagrindu ir teigiamus pažymius konvertuoja labiausiai tikètino vertinimo atitikmens principu, įvertinant pažymio reitingą analizuojamų pažymių grupeje.

4. Triparametris pažymių konvertavimo modelis sudarytas vertinimų skales atitinkančių ECTS vertinimų lentelių pagrindu, ìvertinant konvertuojamos pažymių aibès teigiamų pažymių pasiskirstymą. Kaip ir pirmasis modelis, šis modelis teigiamus pažymius konvertuoja labiausiai tikètino pažymio atitikmens principu, ịvertinant vertinimo reitingą analizuojamų pažymių grupejje.

5. Sukurti vertinimų konvertavimo modelių algoritmai. Lyginant dviparametrio ir triparametrio pažymių konvertavimo modelių algoritmus, nustatyta, kad pagrindiniai šių algoritmų skirtumai atsiranda formuojant pažymių konvertavimo lentelę. Triparametrio pažymių konvertavimo modelio algoritmo atveju, 
sudarant pažymių konvertavimo lentelę, vykdomi parengiamieji pažymių konvertavimo lentelès sudarymo veiksmai.

6. Vertinant pažymių konvertavimo algoritmų sudètingumą, nustatyta, kad triparametrio pažymių konvertavimo modelio algoritmas yra apytiksliai daugiau nei 2 kartus sudètingesnis nei dviparametrio pažymių konvertavimo modelio algoritmas. 


\section{4}

\section{Pažymių konvertavimo modelių eksperimentinis tyrimas}

Atlikta vertinimo modelių ir sistemų analizè išryškino skirtingose aukštojo mokslo institucijose gautu ịvertinimu palyginamumo, skaidrumo, teisingo interpretavimo problemas. Pažymiams konvertuoti iš vienos vertinimo skalès į kitą sukurtas dviparametris ir triparametris vertinimu konvertavimo modelis. Sukurtais pažymių konvertavimo modeliais siekiama supaprastinti pažymių konvertavimo procesą, sumažinti vertinimų konvertavimo neatitikimų atvejų skaičių, spręsti e. mokymosi rezultatų vertinimo technologijų pritaikymo jungtinių e. mokymosi kursų teikimui uždavinius, studijų rezultatų vertinimo aspektu.

Siekiant įvertinti sudarytu pažymių konvertavimo modelių patikimumą, palyginti sukurtus pažymių konvertavimo modelius, eksperimentiškai testuojami sudaryti vertinimų konvertavimo modelių prototipai. Šiame skyrelyje aprašomas vykdomas eksperimentas, pristatomi gauti eksperimentinio testavimo rezultatai, formuluojamos sukurtus pažymių konvertavimo modelius įvertinančios išvados. 


\subsection{Dviparametrio pažymių konvertavimo modelio eksperimentinio testavimo rezultatai}

Vertinimu konvertavimo modelio algoritmas sukurtas $\mathrm{C}++$ kalba, pasitelkus „Borland C++ Builder“ programavimo priemonę. Eksperimentiškai testuojant sukurtą vertinimu konvertavimo modeli, atliekamas tiesioginis bei atvirkštinis teigiamų vertinimų konvertavimas iš vertinimo skalès $A$ i vertinimo skalę $B$. Kiekvienam testavimo atvejui skaičiuojami vertinimu konvertavimo atitikimo ir neatitikimo atvejai. Modelis testuojamas vertinimo skalèse, kurių teigiamiems vertinimams skiriamas vienodas ir skirtingas balu skaičius, tikrinamas modelio teisingumas reitinguojamoje ir nereitinguojamoje teigiamų vertinimų aibeje. Šiame eksperimente skalès dydžiu įvardijamas teigiamiems vertinimams skiriamų pažymių skaičius. Eksperimentas vykdomas vertinimo skalèse, kurių teigiamiems vertinimams skiriama nuo 3 iki 10 skalès vertinimų. Kiekvieną skalès pažymi atitinka po 10 konvertuojamos pažymių aibès vertinimų.

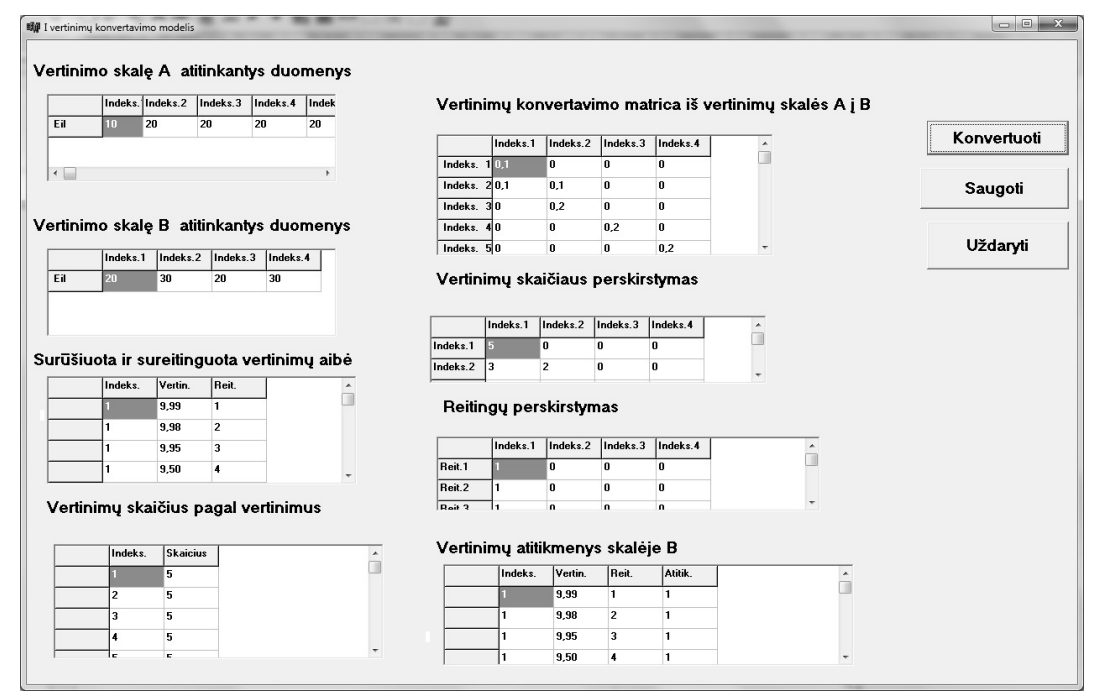

4.1 pav. Dviparametrio pažymių konvertavimo modelio prototipas

Fig. 4.1. A prototype of two-parameter grade conversion model

Eksperimentas pradedamas vienodo dydžio vertinimo skalèse $A$ ir $B$, kurių teigiamų pažymių pasiskirstymas skiriasi neženkliai. Vertinimo skalių $A$ ir $B$ teigiamų pažymių pasiskirstymas yra laikomas neženkliu, jei tenkinami (4.1) nelygybių sistema aprašyti sąryšiai.

$$
\left\{\begin{array}{l}
k_{i}-l_{i}<l_{i} \\
l_{i}-k_{i}<k_{i}
\end{array} \quad i=\overline{1, n}\right.
$$


Eksperimento metu testuojamų vertinimo skalių duomenys sugeneruojami automatiškai, atsižvelgiant i (4.1) nelygybių sistema aprašytus sąryšius. Testuojamų vertinimo skalių pažymių pasiskirstymas pateiktas A priedo A.1 lentelëje. Kiekviena kintamujų $k_{i}$ ir $l_{i} i=\overline{1, n}$ pora tenkina (4.1) nelygybiu sistema aprašytus sąryšius. Vertinimų konvertavimas vienodo dydžio vertinimo skalèse, kurių pažymių pasiskirstymas neženkliai skiriasi, yra tikslus ir vienareikšmis konvertuojant reitinguojamos ir nereitinguojamos vertinimų aibės pažymius. Konvertavimo neatitikimo atvejai nèra gaunami.

Eksperimentas tęsiamas vienodo dydžio vertinimo skalèse $A$ ir $B$, ženkliai besiskiriančiose pažymių pasiskirstymu. Vertinimo skalių $A$ ir $B$ pažymių pasiskirstymo skirtumas yra laikomas ženkliu, jei netenkinami (4.1) nelygybių sistema aprašyti sąryšiai. Automatiškai sugeneruotų testuojamų vertinimo skalių pažymių pasiskirstymas pateiktas A priedo A.2 lentelëje. Testuojamų vertinimo skalių $A$ ir $B$ nors viena kintamujų $k_{i}$ ir $l_{i} i=\overline{1, n}$ pora netenkina (4.1) nelygybių sistema aprašytų sąryšių.

Konvertavimo neatitikimo atvejai yra gaunami, konvertuojant nereitinguojamus teigiamus vertinimus vienodo dydžio vertinimo skalèse, ženkliai besiskiriančiose pažymių pasiskirstymu (4.2 pav.). Kiekvienam testavimo atvejui gaunama vieno iš teigiamų skalès pažymių konversijos neatitiktis. Kiekvieną teigiamą skalès pažymį atitinka po 10 konvertuojamos pažymių aibès vertinimų, todèl kiekvienu testavimo atveju gaunama 10 pažymių konversijos neatitiktis. Konvertuojant pažymius 4 teigiamų balų vertinimo skalejje, konversijos neatitikimo atvejų skaičius sudaro 25 proc., 6 teigiamų balų vertinimo skalèje - 16,67 proc., 7 teigiamų balų $-14,29$ proc. ir 10 teigiamų balų -10 proc. konvertuojamos pažymių aibės vertinimų (4.2 pav.).

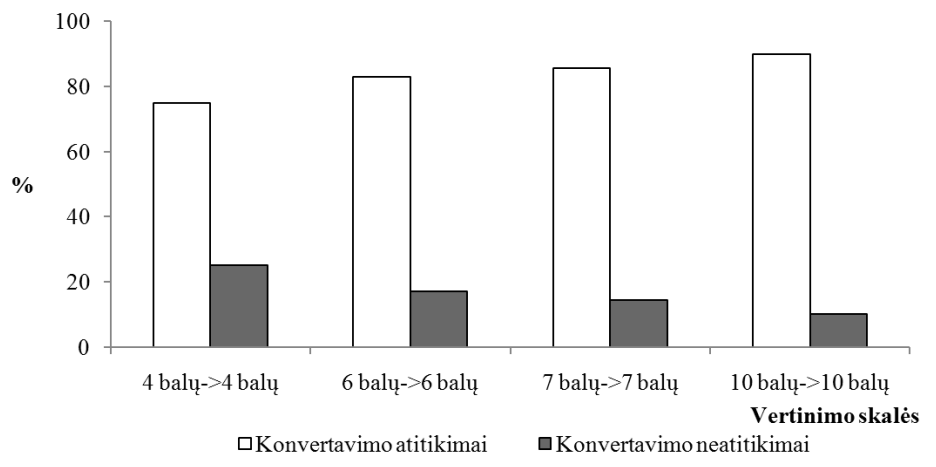

4.2 pav. Pažymių konvertavimo rezultatai vienodo dydžio vertinimo skalėse, kurių pažymių pasiskirstymas ženkliai skiriasi

Fig. 4.2. The results of conversion of grades on grading scales of the same size, and grades distribution of which varies significantly 
Pažymių konvertavimo neatitikimo atvejai yra gaunami visiems testuojamos duomenų aibès vertinimams, netenkinantiems (4.2) lygybe aprašytų sąryšių.

$$
a_{i}=b_{j} \text {, jei } \max \left(p_{i 1} ; \ldots ; p_{i m}\right)=\max \left(p_{1 j} ; \ldots ; p_{m j}\right)=p_{i j} i=\overline{1, m} \quad j=\overline{1, m}
$$

Tęsiant eksperimentą kontrolinès pažymių aibès vertinimams priskiriami reitingai. Priskiriamų reitingų skaičius yra minimalus, skirtingą skalès pažymį atitinkantiems vertinimams, priskiriami skirtingi reitingai. Taigi 4 teigiamų balų vertinimo skalëje visiems vertinimams atitinkantiems pažymị 4, priskiriamas reitingas 1 , pažymį 3 - reitingas 2 , pažymi 2 - reitingas 3 , o pažymi 1 - reitingas 4. Priskiriamų reitingų skaičius priklauso nuo skalès dydžio, t.y. teigiamų vertinimo skalès pažymių skaičiaus (4.3 pav.). Atliekant konvertavimą reitinguojamoje pažymių aibẻje klaidingi konvertavimo atvejai nèra gaunami.

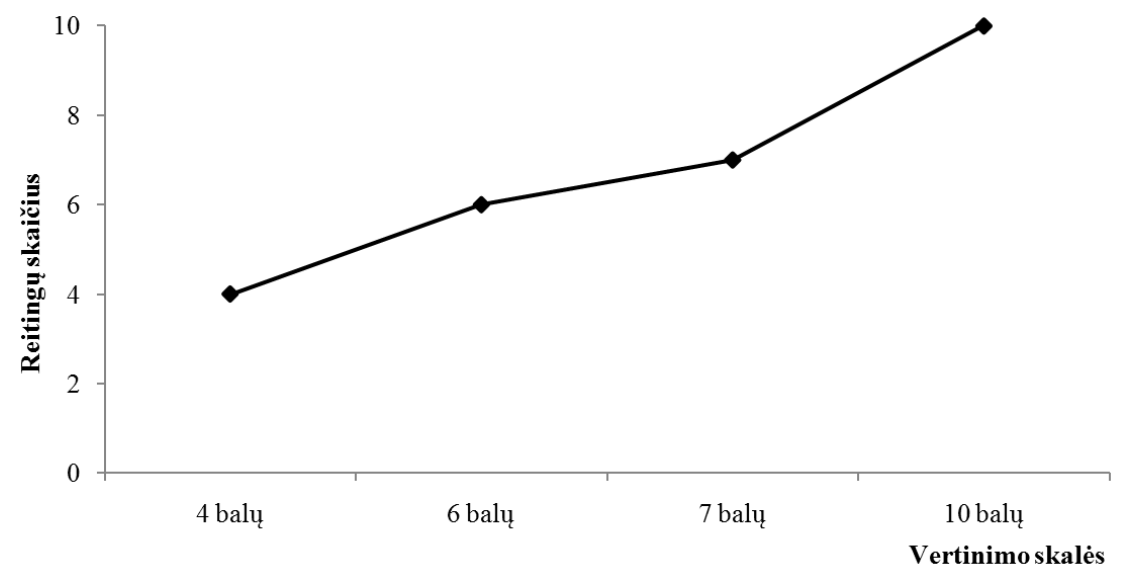

4.3 pav. Priskiriamų reitingų skaičiaus ir skalès dydžio priklausomybès

Fig. 4.3. The number of ascribable ratings and the scale size dependence

Eksperimentas tęsiamas skirtingo dydžio vertinimo skalèse $A$ Šiose vertinimo skalèse teigiamiems vertinimams skiriamas skirtingas teigiamų balų skaičius. Testuojamų vertinimo skalių dydžių skirtumas svyruoja nuo 1 iki 7 balų. Eksperimentas vykdomas 4 ir 3 teigiamų balų, 7 ir 5 teigiamų balų bei 10 ir 3 teigiamų balų vertinimo skalèse. Automatiškai sugeneruotas testuojamų vertinimo skalių pažymių pasiskirstymas pateiktas A priedo A.3 lentelèje.

Vertinimų konvertavimo neatitikimo atvejai nėra gaunami konvertuojant pažymius skirtingo dydžio vertinimo skalèse, kai pažymiai tiesiogiai konvertuojami iš mažesnès i didesnę vertinimo skalę. Ši vertinimu konversija yra tiksli tiek reitinguojamoje, tiek nereitinguojamoje pažymių aibejje. Tačiau nereitinguojamos pažymių vertinimų aibės atitikmenys netolygiai pasiskirsto naujojoje vertinimo skalèje. 
Pažymius konvertuojant iš didesnès ị mažesnę vertinimo skalę nereitinguojamoje vertinimų aibejje, gaunami pažymių konversijos neatitikimo atvejai. Eksperimentinio testavimo rezultatai rodo, kad vertinimu konvertavimo neatitikimo atvejų skaičius nereitinguojamoje vertinimų aibejje priklauso nuo vertinimo skalių dydžio skirtumo, t.y. teigiamiems vertinimams skirtu balų skaičiaus skirtumo. Didejjant vertinimo skalių $A$ ir $B$ dydžių skirtumui, didejja ir vertinimų konvertavimo neatitikimų skaičius (4.4 pav.).

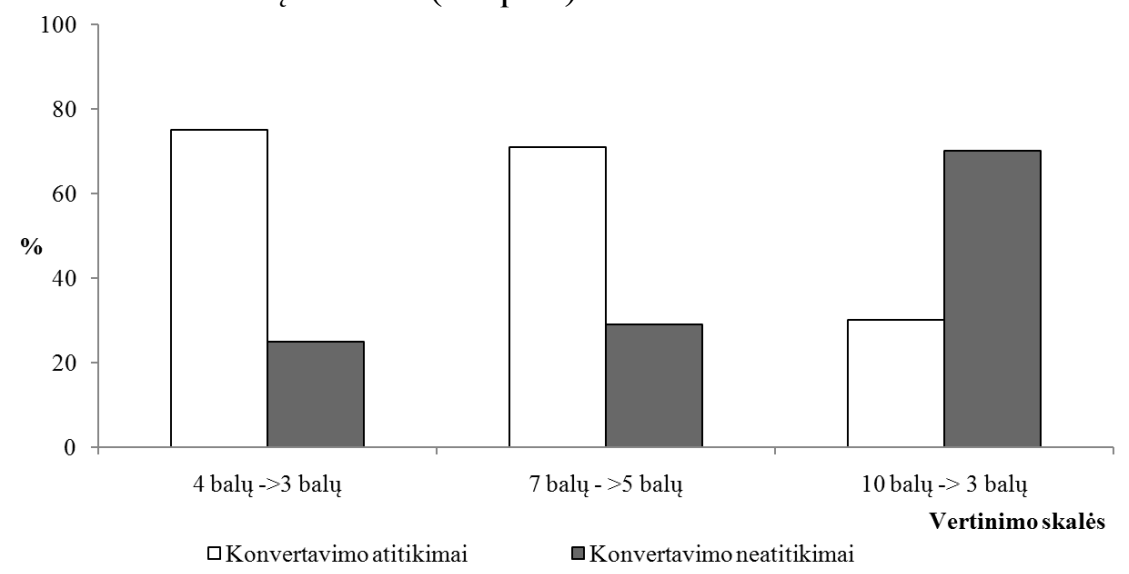

4.4 pav. Pažymių konvertavimo rezultatai skirtingo dydžio vertinimo skalèse Fig. 4.4. The results of conversion of grades on grading scales of the different size

Konvertavimo neatitikimo atvejai gaunami visiems vertinimams, netenkinantiems (4.2) lygybe aprašytu sąryšių. Tęsiant eksperimentą reitinguojamoje kontrolinejje pažymių aibëje pastebèta, kad minimalus reitingų skaičius užtikrinantis vienareikšmį teigiamų vertinimų konvertavimą iš didesnès i mažesnę vertinimų skalę yra lygus didesnès vertinimo skalès dydžiui, t.y. skalès teigiamiems vertinimams skirtų pažymių skaičiui (4.5 pav.).

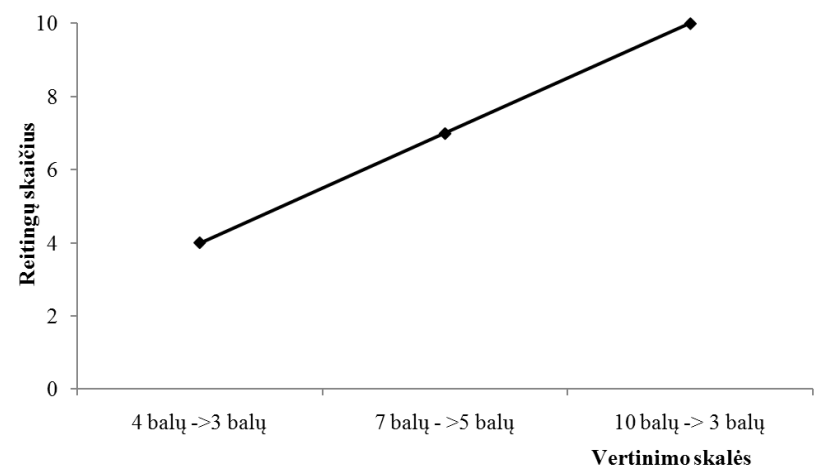

4.5 pav. Minimalaus reitingų skaičiaus ir skalès dydžio priklausomybės

Fig. 4.5. The number of ratings and the scale size dependence 
Šio reitingų skaičiaus pakanka vienareikšmei atvirkštinei vertinimų konversijai atlikti, jei teigiamų pažymių pasiskirstymas didesnèje vertinimo skalèje neženkliai skiriasi nuo teigiamų vertinimų pasiskirstymo pagal reitingus.

\subsection{Triparametrio pažymių konvertavimo modelio eksperimentinio testavimo rezultatai}

Tęsiant eksperimentą testuojamas triparametris pažymių konvertavimo modelis, ivertinantis konvertuojamos teigiamų pažymių aibès duomenų pasiskirstymą. Konvertuojamą pažymių aibę, kaip ir dviparametrio modelio testavimo atveju, sudaro tik teigiami pažymiai. Triparametrio pažymių konvertavimo modelio prototipas sukurtas $\mathrm{C}++$ kalba, pasitelkus „Borland $\mathrm{C}++$ Builder“ programavimo priemonę. Kaip ir pirmojo modelio atveju, testavimas pradedamas vienodo dydžio vertinimo skalèse $A$ ir $B$, t. y. vertinimo skalèse, kurių teigiamiems vertinimams yra skiriamas vienodas balu skaičius. Skiriami keturi triparametrio pažymių konvertavimo modelio testavimo vienodo dydžio vertinimo skalèse atvejai. Pirmasis ir antrasis eksperimentinio testavimo atvejis yra skirtas pažymių konvertavimo vienodo dydžio vertinimo skalèse $A$ ir $B$, kurių teigiamų pažymių pasiskirstymas skiriasi neženkliai, tyrimui atlikti. Eksperimente pasirinktos dviparametrio pažymių konvertavimo modelio testavimui taikytos studijų rezultatų vertinimo skalès. Testuojamų vertinimo skalių teigiamų pažymių pasiskirstymas pateiktas A priedo A.1 lentelèje.

Vykdant eksperimentą keičiamas trečiasis pažymių konvertavimui įtaką darantis parametras - konvertuojamos pažymių aibès duomenų pasiskirstymas. Konvertuojamų pažymių aibe sugeneruojama automatiškai pagal iš anksto aprašytas eksperimento sąlygas. Konvertuojamą pažymių aibę sudaro 100 teigiamų vertinimų. Pirmuoju testavimo atveju konvertuojamos ir sukauptos pažymių aibès, aprašytos vertinimo skalès $A$ ECTS lentele, pasiskirstymai neženkliai skiriasi, t. y. tenkinami (4.1) lygčių sistema aprašyti sąryšiai. Automatiškai sugeneruotos konvertuojamos pažymių aibès duomenų pasiskirstymas pateiktas B priedo B.1 lentelèje.

Kai konvertuojamos pažymių aibès duomenų pasiskirstymas neženkliai skiriasi nuo vertinimo skalès $A$ ECTS lentele aprašyto pažymių pasiskirstymo, triparametrio ir dviparametrio pažymių konvertavimo modelių testavimo rezultatai sutampa. Konvertuojant pažymių aibę, sudarytą iš 100 vertinimų, konvertavimo skirtumai, taikant 1-ajji ir 2-aji pažymių konvertavimo modeli nèra gaunami. Kaip ir dviparametrio modelio atveju, vertinimų konvertavimas vienodo dydžio vertinimo skalèse, kurių pažymių pasiskirstymas neženkliai skiriasi, yra tikslus ir vienareikšmis konvertuojant reitinguojamos ir nereitinguojamos teigiamų vertinimų aibès pažymius. Konvertavimo neatitikimo atvejai nèra gaunami. 
Tęsiant eksperimentą tikrinami reitinguojamos teigiamų pažymių aibès konvertavimo skirtumai, taikant 1-ajji ir 2-aji pažymių konvertavimo modelị. Kiekvieną kartą konvertuojamą pažymių aibę padidinus 10 kartų, nagrinejjami pažymių konvertavimo neatitikimo atvejai, taikant 1-ajji ir 2-aji pažymių konvertavimo modelį. Pažymių konvertavimo neatitikimo atvejų skaičiaus priklausomybè nuo konvertuojamos pažymių aibès dydžio pavaizduota 4.6 paveiksle. Šiuo testavimo atveju pažymių konvertavimo skirtumai gaunami septynių teigiamų balų studijų rezultatų vertinimo skalèje, konvertuojant 100000 dydžio pažymių aibę.

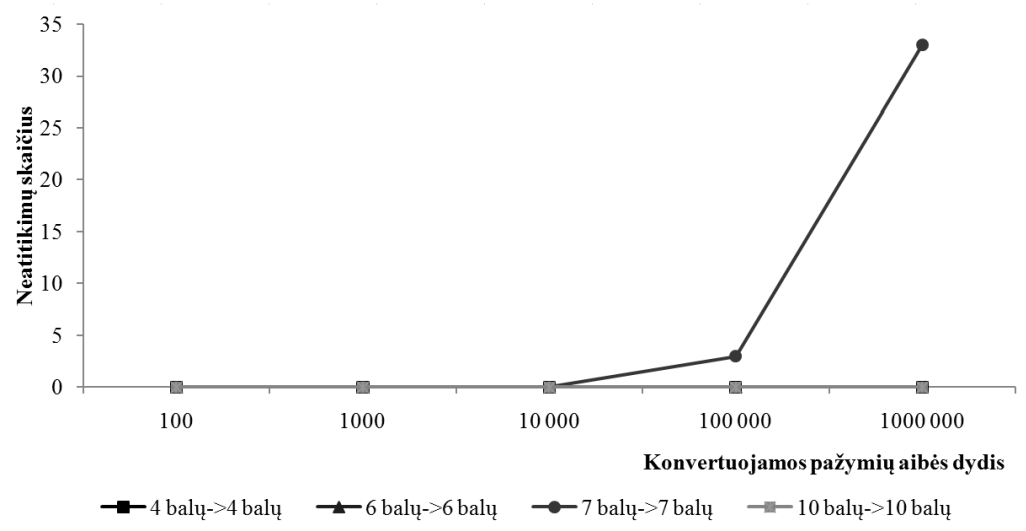

4.6 pav. 1-ojo ir 2-ojo modelio konvertavimo neatitikimo atvejai, konvertuojant pažymius vienodo dydžio vertinimo skalėse 1-uoju testavimo atveju

Fig. 4.6. The irrelevancies of conversion of first and second model, while conversion of grades is carried out on grading scales of the same size in the first test case

Pažymių konvertavimo metodų skirtumai sąlygoja šių dviejų modelių pažymių konvertavimo skirtumus. Analizuojant 1-ojo ir 2-ojo pažymių konvertavimo modelių suformuotas pažymių konvertavimo lenteles pastebèta, kad vertinimų konvertavimo neatitikimo atvejai, reitinguojamoje pažymių aibejje gaunami tuomet, kai nors vienai, suformuotų tikimybinių skirstinių reikšmių pasirodymo tikimybių porai, yra teisingi (4.3) formule aprašyti sąryšiai. Šioje formuleje $p 1_{i j}$ ir $p 2_{i j}$ atitinkamai žymi 1-ojo ir 2-ojo modelių suformuotų dvimačių tikimybinių skirstinių reikšmių pasirodymo tikimybes.

$$
\frac{p 1_{i j}}{\sum_{k=1}^{m} p 1_{i k}} \neq \frac{p 2_{i j}}{\sum_{k=1}^{m} p 2_{i k}} i=\overline{1, m} j=\overline{1, m}
$$

Pažymėję (4.3) formule aprašytų santykių skirtumus $\Delta_{\mathrm{ij}}$ gauname, kad 1-ojo ir 2-ojo modelių pažymių konvertavimo reitinguojamoje pažymių aibejje neatiti- 
kimo atvejų skaičius tiesiogiai priklauso nuo dydžių $\Delta_{\mathrm{ij}} i=\overline{1, n}, j=\overline{1, m}$ reikšmių. Kadangi 1-uoju testavimo atveju maksimali dydžių $\Delta_{\mathrm{ij}} i=\overline{1, n}, j=\overline{1, m}$ reikšmè septynių teigiamų balų vertinimo skalèje yra $10^{-5}$ eilès skaičius, todèl pirmieji šių dviejų modelių pažymių konvertavimo skirtumai gaunami konvertuojant 100000 reitinguojamą pažymių aibę.

$$
\Delta_{i j}=\left|\frac{p 1_{i j}}{\sum_{k=1}^{m} p 1_{i k}}-\frac{p 2_{i j}}{\sum_{k=1}^{m} p 2_{i k}}\right| \quad i=\overline{1, m} \quad j=\overline{1, m}
$$

Tęsiant eksperimentą vienodo dydžio vertinimo skalèse $A$ ir $B$, kurių teigiamų pažymių pasiskirstymas skiriasi neženkliai, automatiškai sugeneruojamos konvertuojamų teigiamų pažymių aibès, kurių pažymių pasiskirstymai ženkliai skiriasi nuo vertinimo skalès $A$ ECTS lentele aprašytų pažymių pasiskirstymų. Suformuotų konvertuojamų pažymių aibių duomenų pasiskirstymai pateikti B priedo B.2 lenteleje. Kaip ir pirmuoju testavimo atveju, vertinimų konvertavimas vienodo dydžio vertinimo skalèse, kurių teigiamų pažymių pasiskirstymas neženkliai skiriasi, yra tikslus ir vienareikšmis konvertuojant reitinguojamos ir nereitinguojamos teigiamų vertinimų aibès pažymius. Tiriant reitinguojamos teigiamų pažymių aibès konvertavimo skirtumus, taikant 1-ajji ir 2-aji pažymių konvertavimo modelius, konvertuojamų pažymių aibẻ yra didinama 10 kartų ir nagrinėjami pažymių konvertavimo neatitikimo atvejai. Pažymių konvertavimo neatitikimo atvejų skaičiaus priklausomybè nuo konvertuojamos pažymių aibės dydžio pavaizduota žemiau pateiktame paveiksle.

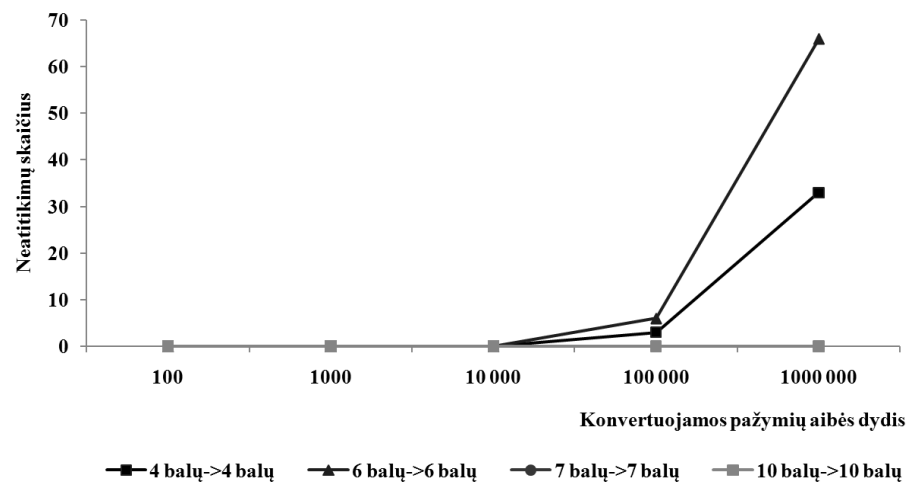

4.7 pav. 1-ojo ir 2-ojo modelio konvertavimo neatitikimo atvejai konvertuojant pažymius vienodo dydžio vertinimo skalèse 2-uoju testavimo atveju

Fig. 4.7. The irrelevancies of conversion of first and second model, while conversion of grades is carried out on grading scales of the same size in the second test case 
Pažymių konvertavimo skirtumai, taikant dviparametrị ir triparametrị vertinimų konvertavimo modeli, gaunami konvertuojant vertinimus šešių ir keturių teigiamų balų studijų rezultatų vertinimo skalèse. Pirmieji vertinimų konversijos neatitikimai gaunami konvertuojant 100000 dydžio teigiamų pažymių aibę. Pažymių konversijos neatitikimo atvejai nèra gaunami septynių ir dešimties teigiamų balų vertinimo skalèse. Šiose studijų rezultatų vertinimo skalèse dviparametris ir triparametris pažymių konvertavimo modelis vertinimus konvertuoja vienareikšmiškai.

Triparametrio pažymių konvertavimo modelio testavimas tęsiamas vienodo dydžio vertinimo skalèse $A$ ir $B$ ženkliai besiskiriančiose pažymių pasiskirstymu. Eksperimente pasirinktos dviparametrio pažymiu konvertavimo modelio testavimui taikytos studijų rezultatų vertinimo skalès. Testuojamų vertinimo skalių teigiamų pažymių pasiskirstymas pateiktas A priedo A.2 lentelëje.

Šiuo testavimo atveju sugeneruojama konvertuojamų teigiamų pažymių aibé, kurios duomenų pasiskirstymas neženkliai skiriasi nuo vertinimo skalès $A$ ECTS lentele aprašyto pažymių pasiskirstymo. Konvertuojamos pažymių aibės duomenų pasiskirstymas pateiktas B priedo B.3 lentelèje. Kaip ir dviparametrio pažymių konvertavimo modelio testavimo atveju, vienam vertinimo skalès pažymiui gaunami konvertavimo neatitikimo atvejai, konvertuojant nereitinguojamus teigiamus vertinimus vienodo dydžio vertinimo skalèse, ženkliai besiskiriančiose pažymių pasiskirstymu. Pažymių konvertavimo rezultatai nereitinguojamoje vertinimu aibeje 3-uoju testavimo atveju pateikti 4.8 paveiksle.

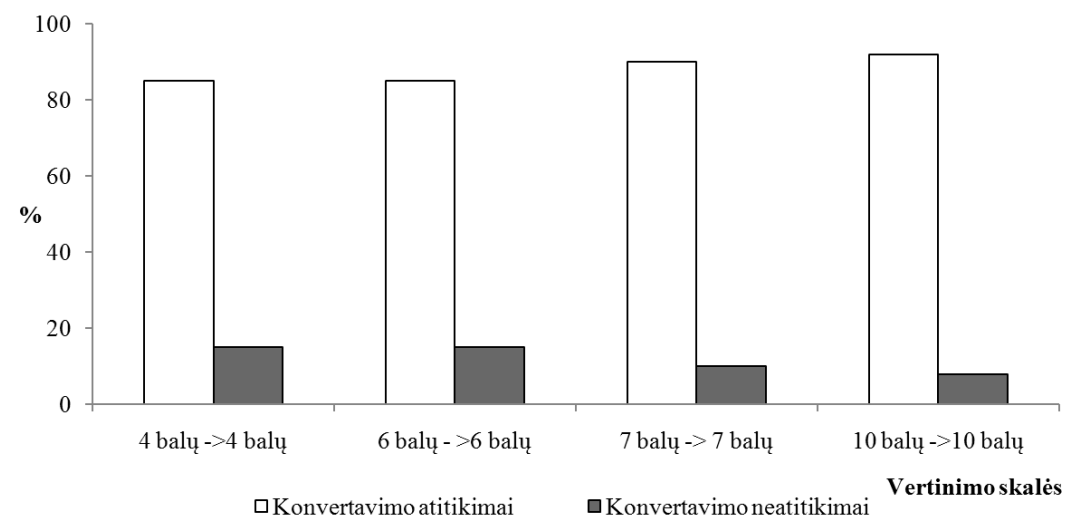

4.8 pav. Pažymių konvertavimo rezultatai vienodo dydžio vertinimo skalèse 3-uoju testavimo atveju

Fig. 4.8. The results of conversion of grades on grading scales of the same size in the third test case

Tęsiant eksperimentą analizuojami reitinguojamos teigiamų pažymių aibès konvertavimo skirtumai taikant 1-aji ir 2-aji pažymių konvertavimo modelị. Tei- 
giamų vertinimų konversijos neatitikimo atvejai gaunami konvertuojant pažymius šešių ir septynių teigiamų balų studijų rezultatų vertinimo skalèse, kai konvertuojamos pažymių aibès dydis - 100000 įrašų (4.9 pav.).

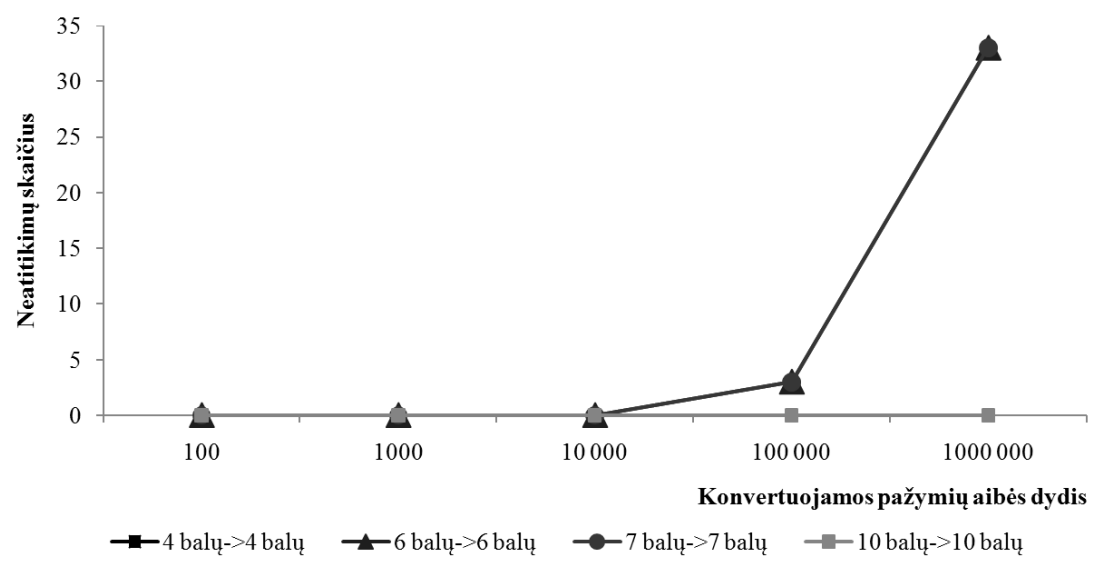

4.9 pav. 1-ojo ir 2-ojo modelio konvertavimo neatitikimo atvejai, konvertuojant pažymius vienodo dydžio vertinimo skalèse 3-uoju testavimo atveju

Fig. 4.9. The irrelevancies of conversion of first and second model, while conversion of grades is carried out on grading scales of the same size in the third test case

Šiuo testavimo atveju maksimali (4.4) formule aprašytų dydžių $\Delta_{\mathrm{ij}}$ $i=\overline{1, n}, j=\overline{1, m}$ reikšmè šešių ir septynių balų studijų rezultatų vertinimo skalèse yra $10^{-5}$ eilès skaičius. Todèl pirmieji dviparametrio ir triparametrio pažymių konvertavimo modelių teigiamų vertinimu konvertavimo reitinguojamoje pažymių aibèje skirtumai gaunami 100000 dydžio vertinimų aibejje.

Tęsiant eksperimentą vienodo dydžio vertinimo skalėse $A$ ir $B$, ženkliai besiskiriančiose pažymių pasiskirstymu, sugeneruojama konvertuojamų teigiamų pažymių aibè, kurios duomenų pasiskirstymas ženkliai skiriasi nuo vertinimo skalès $A$ ECTS lentele aprašyto pažymių pasiskirstymo. Konvertuojamos pažymių aibès duomenų pasiskirstymas pateiktas B priedo B.4 lentelèje.

Kaip ir 3-uoju testavimo atveju teigiamų pažymių konvertavimo neatitikimo atvejai gaunami konvertuojant nereitinguojamos pažymių aibės vertinimus. Kiekvienos eksperimento metu tiriamos studijų rezultatų vertinimo skalès vienam iš pažymių gaunama konversijos neatitiktis (4.10 pav.). Konvertuojant pažymius 4 teigiamų balų vertinimo skaleje, konversijos neatitikimo atvejų skaičius sudaro 13 proc., 6 teigiamų balų vertinimo skalejje -5 proc., 7 teigiamų balų - 10 proc. ir 10 teigiamų balų -5 proc. konvertuojamos pažymių aibès vertinimų. 


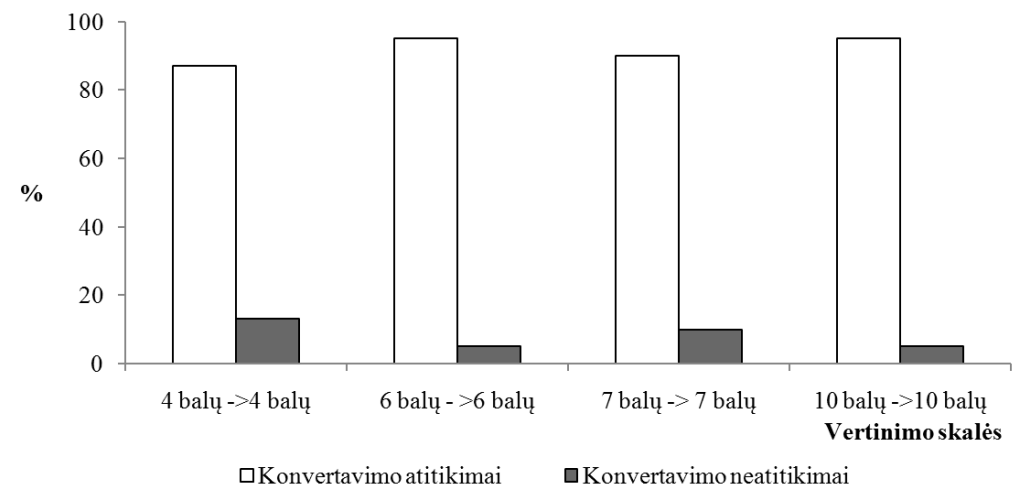

4.10 pav. Pažymių konvertavimo rezultatai vienodo dydžio vertinimo skalèse 4uoju testavimo atveju

Fig. 4.10. The results of conversion of grades on grading scales of the same size in the fourth test case

1-ojo ir 2-ojo pažymių konvertavimo modelio skirtumai gaunami konvertuojant reitinguojamos teigiamų pažymių aibès vertinimus. Šiuo testavimo atveju vertinimų konversijos neatitikimo atvejai gaunami konvertuojant pažymius šešių ir septynių teigiamų balų studijų rezultatų vertinimo skalèse, kai konvertuojamos pažymių aibès dydis - 100000 ịrašų (4.11 pav.).

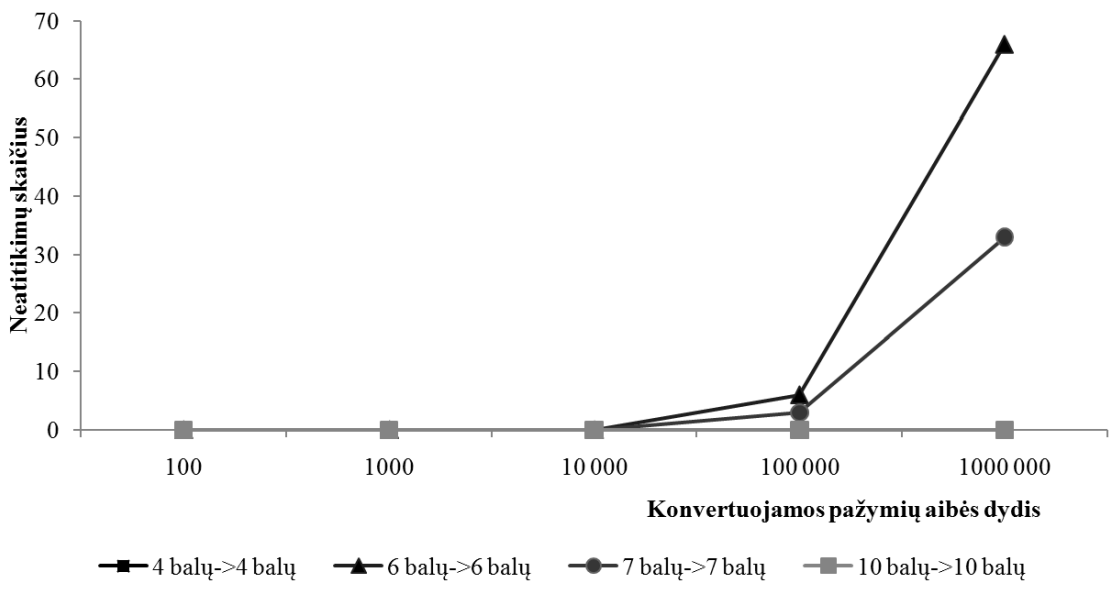

4.11 pav. 1-ojo ir 2-ojo modelio konvertavimo neatitikimo atvejai, konvertuojant pažymius vienodo dydžio vertinimo skalèse 4-uoju testavimo atveju

Fig. 4.11. The irrelevancies of conversion of first and second model, while conversion of grades is carried out on grading scales of the same size in the fourth test case 
Triparametrio pažymių konvertavimo modelio testavimas tęsiamas skirtingo dydžio studijų rezultatų vertinimo skalèse $A$ ir $B$, t.y. vertinimo skalèse, kurių teigiamiems vertinimams skiriamas skirtingas balų skaičius. Skiriami keturi triparametrio pažymių konvertavimo modelio testavimo skirtingo dydžio vertinimo skalèse atvejai. Pirmuoju testavimo atveju tikrinamas triparametrio pažymių konvertavimo modelio teisingumas konvertuojant pažymių aibę, kurios teigiamų duomenų pasiskirstymas neženkliai skiriasi nuo vertinimo skalès $A$ ECTS lentele aprašyto pažymių pasiskirstymo. Šiuo testavimo atveju pažymių konvertavimas vykdomas iš didesnès ị mažesnę studijų rezultatų vertinimo skalę. Konvertuojamos pažymių aibès duomenų pasiskirstymas pateiktas B priedo B.5 lenteleje.

Konvertuojant nereitinguojamos teigiamų pažymių aibès vertinimus iš didesnès į mažesnę vertinimo skalę, kaip ir 1-ojo pažymių konvertavimo modelio atveju, gaunami pažymių konversijos neatitikimo atvejai. Triparametrio pažymių konvertavimo modelio eksperimentinio testavimo rezultatai rodo, kad teigiamų vertinimų konvertavimo neatitikimo atvejų skaičius nereitinguojamoje vertinimų aibeje priklauso nuo vertinimo skalių dydžio skirtumo, t.y. teigiamiems vertinimams skiriamų pažymių skaičiaus skirtumo. Didejant vertinimo skalių $A$ ir $B$ dydžių skirtumui, didẻja ir vertinimų konvertavimo neatitikimų skaičius (4.12 pav.). Taigi šiuo testavimo atveju teigiamų vertinimų konvertavimo rezultatai, taikant dviparametrị ir triparametrị pažymių konvertavimo modeli, sutampa.

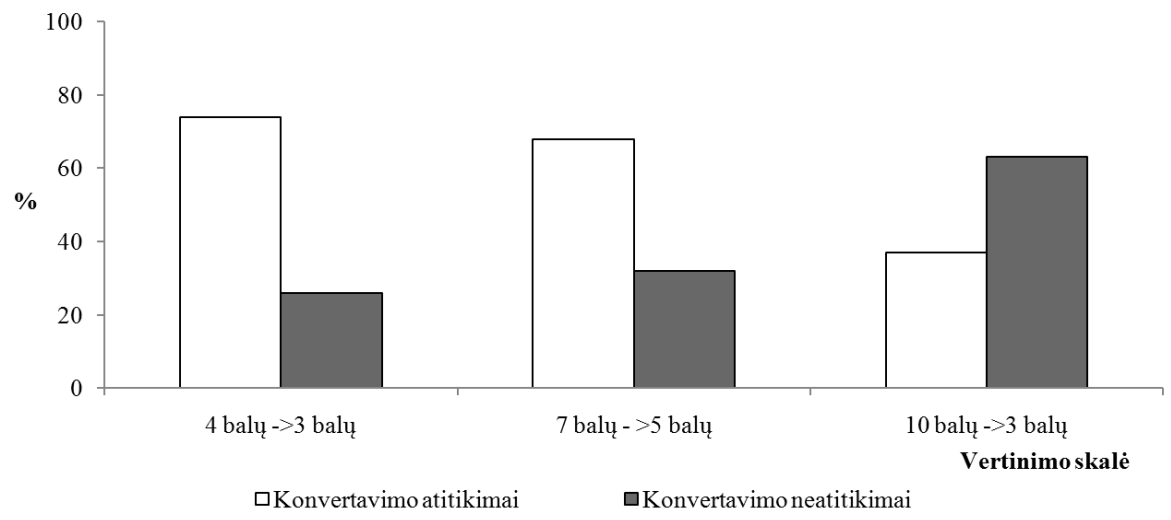

4.12 pav. Pažymių konvertavimo rezultatai skirtingo dydžio vertinimo skalèse 1uoju testavimo atveju

Fig. 4.12. The results of conversion of grades on grading scales of the different size in the first test case

Keičiant konvertuojamos pažymių aibės dydi analizuojami pažymių konvertavimo reitinguojamoje pažymių aibejje skirtumai taikant 1-aji ir 2-aji pažymių konvertavimo modelį. Siuo testavimo atveju teigiamų pažymių konvertavimo skirtumai gaunami konvertuojant pažymius iš keturių i trijų teigiamų balų verti- 
nimo skalę. Pirmieji pažymių konvertavimo neatitikimo atvejai gaunami, kai konvertuojamos pažymių aibès dydis siekia 100000 įrašų.

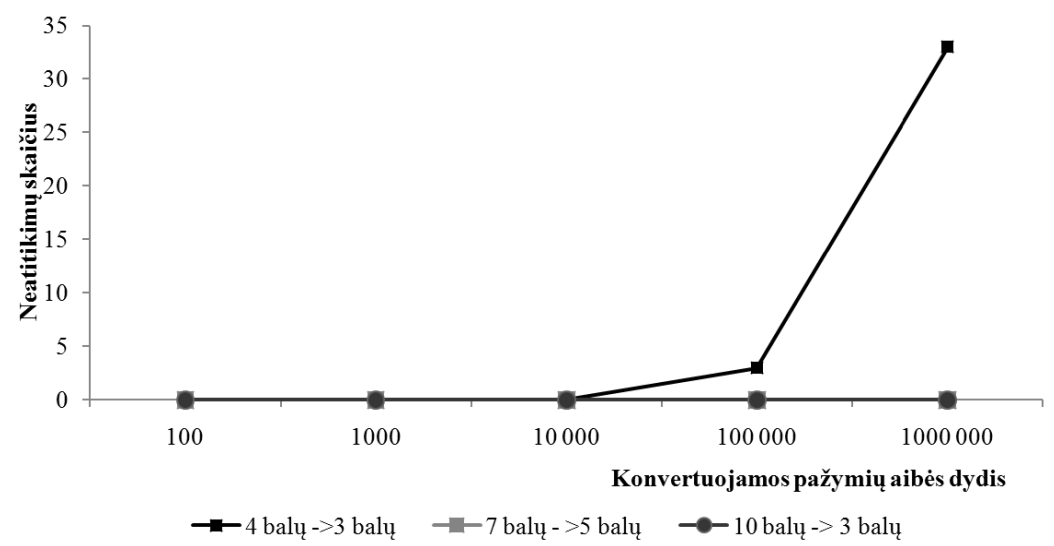

4.13 pav. 1-ojo ir 2-ojo modelio konvertavimo neatitikimo atvejai konvertuojant pažymius skirtingo dydžio vertinimo skalèse 1-uoju testavimo atveju

Fig. 4.13. The irrelevancies of conversion of first and second model, while conversion of grades is carried out on grading scales of the different size in the first test case

Antruoju testavimo atveju tikrinamas triparametrio pažymių konvertavimo modelio teisingumas konvertuojant teigiamų pažymių aibę, kurios duomenų pasiskirstymas neženkliai skiriasi nuo vertinimo skalès $A$ ECTS lentele aprašyto pažymių pasiskirstymo. Šiuo testavimo atveju teigiamų pažymių konvertavimas vykdomas iš mažesnès į didesnę studijų rezultatų vertinimo skalę. Konvertuojamos teigiamų pažymių aibės duomenų pasiskirstymas pateiktas B priedo B.6 lentelèje.

Kaip ir dviparametrio pažymių konvertavimo modelio atveju, teigiamų vertinimų konvertavimo neatitikimo atvejai nėra gaunami konvertuojant pažymius skirtingo dydžio vertinimo skalèse, kai tiesioginis pažymių konvertavimas vykdomas iš mažesnès i didesnę vertinimo skalę. Ši vertinimų konversija yra tiksli tiek reitinguojamoje, tiek nereitinguojamoje pažymių aibejje. Tačiau nereitinguojamos pažymių vertinimų aibės atitikmenys netolygiai pasiskirsto naujojoje vertinimo skalejje.

Šiuo testavimo atveju 1-ojo ir 2-ojo pažymių konvertavimo modelio skirtumai išryškejja konvertuojant reitinguojamą 10000 dydžio pažymių aibę. Pažymių konvertavimo neatitikimo atvejų skaičiaus priklausomybė nuo konvertuojamos pažymių aibès dydžio pavaizduota 4.14 paveiksle. Šiuo testavimo atveju gaunami teigiamų pažymių konvertavimo skirtumai, taikant dviparametrị ir triparametrị pažymių konvertavimo modelị visose testuojamose vertinimo skalèse. 


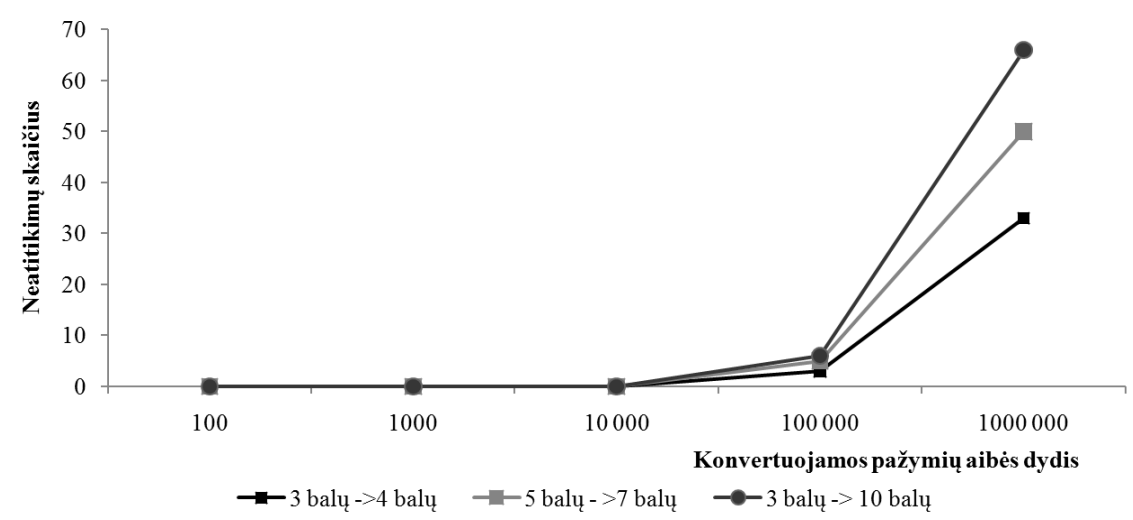

4.14 pav. 1-ojo ir 2-ojo modelio konvertavimo neatitikimo atvejai konvertuojant pažymius skirtingo dydžio vertinimo skalèse 2-uoju testavimo atveju

Fig. 4.14. The irrelevancies of conversion of first and second model, while conversion of grades is carried out on grading scales of the different size in the second test case

Trečiuoju testavimo atveju tikrinamas triparametrio pažymių konvertavimo modelio teisingumas konvertuojant teigiamų pažymių aibę, kurios duomenų pasiskirstymas ženkliai skiriasi nuo vertinimo skalès $A$ ECTS lentele aprašyto pažymių pasiskirstymo. Šiuo testavimo atveju pažymių konvertavimas vykdomas iš didesnès ị mažesnę studijų rezultatų vertinimo skalę. Konvertuojamos teigiamų pažymių aibès duomenų pasiskirstymas pateiktas B priedo B.7 lentelejje. Konvertuojant nereitinguojamos teigiamų pažymių aibès vertinimus gaunami pažymių konvertavimo neatitikimo atvejai (4.15 pav.).

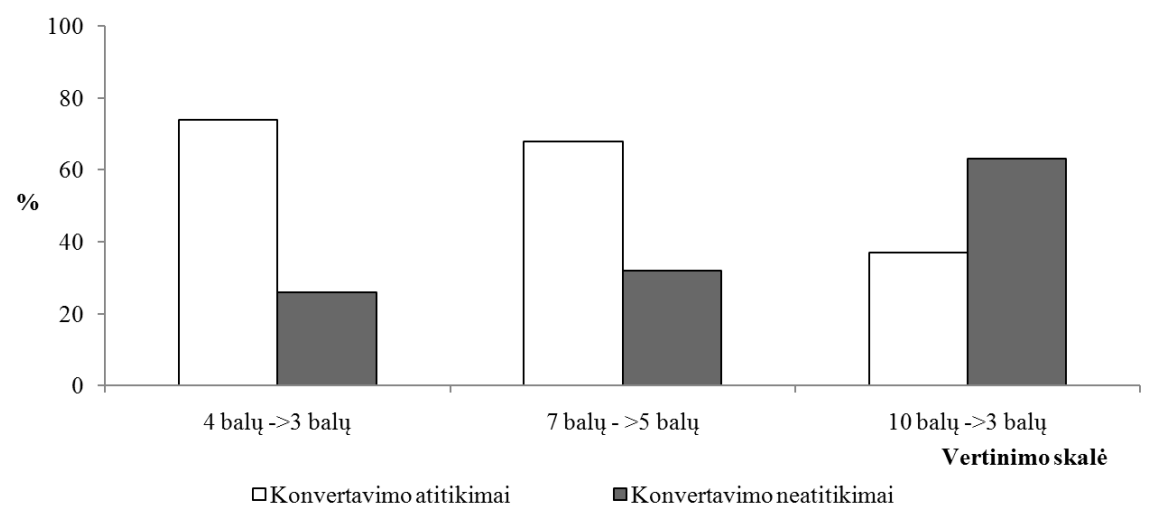

4.15 pav. Pažymių konvertavimo rezultatai skirtingo dydžio vertinimo skalėse 3-uoju testavimo atveju

Fig. 4.15. The results of conversion of grades on grading scales of the different size in the third test case 
Kaip ir 1-uoju testavimo atveju, teigiamų pažymių konversijos neatitikimo atvejų skaičius tiesiogiai priklauso nuo vertinimo skalių dydžių skirtumo, t.y. teigiamiems vertinimams skirtų balų skirtumo. Didejjant vertinimo skalių $A$ ir $B$ dydžių skirtumui, didejja ir vertinimų konvertavimo neatitikimų skaičius (4.15 pav.).

Šiuo testavimo atveju gaunami dviparametrio ir triparametrio pažymių konvertavimo modelio skirtumai konvertuojant reitinguojamos teigiamu pažymių aibės vertinimus iš keturių ị trijų teigiamų balų vertinimo skalę. Pažymių konvertavimo neatitikimo atvejų skaičiaus priklausomybè nuo konvertuojamos pažymių aibès dydžio pavaizduota 4.16 paveiksle. Pirmieji pažymių konversijos neatitikimo atvejai gaunami 100000 dydžio konvertuojamoje pažymių aibèje.

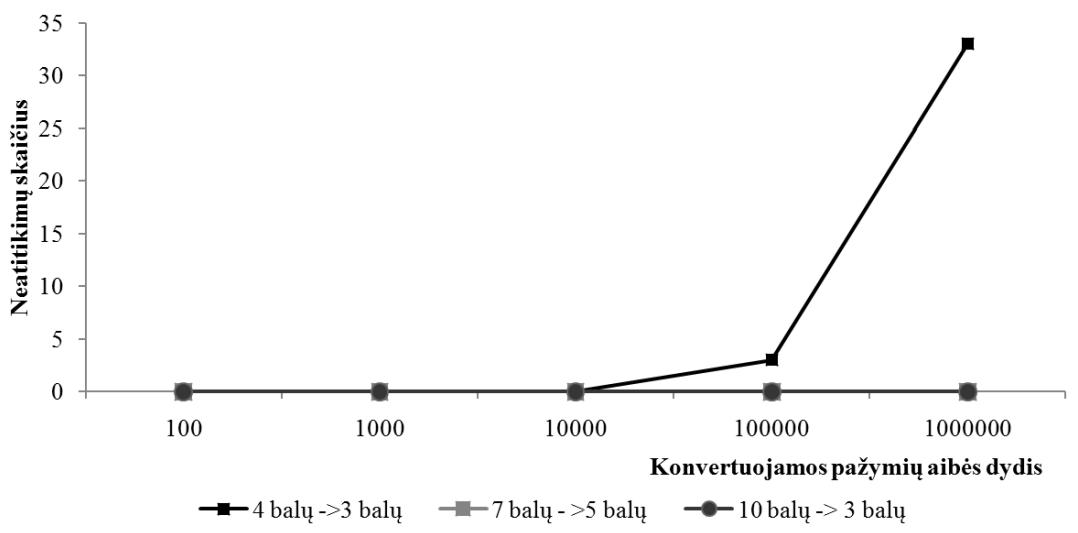

4.16 pav. 1-ojo ir 2-ojo modelio konvertavimo neatitikimo atvejai konvertuojant pažymius skirtingo dydžio vertinimo skalèse 3-uoju testavimo atveju

Fig. 4.16. The irrelevancies of conversion of first and second model, while conversion of grades is carried out on grading scales of the different size in the third test case

Paskutiniuoju testavimo atveju tikrinamas triparametrio pažymių konvertavimo modelio teisingumas konvertuojant pažymių aibę, kurios duomenų pasiskirstymas ženkliai skiriasi nuo vertinimo skalès $A$ ECTS lentele aprašyto pažymių pasiskirstymo. Šiuo testavimo atveju pažymiai konvertuojami iš mažesnès i didesnę studijų rezultatų vertinimo skalę. Konvertuojamos pažymių aibès duomenu pasiskirstymas pateiktas B priedo B.8 lenteleje.

Šiuo testavimo atveju nereitinguojamos pažymių aibès konversijos neatitikimai nèra gaunami. Ši vertinimu konversija yra tiksli tiek reitinguojamoje, tiek nereitinguojamoje pažymių aibèje. Tačiau nereitinguojamos pažymių vertinimų aibès atitikmenys netolygiai pasiskirsto naujojoje vertinimo skaleje.

Paskutiniuoju testavimo atveju 1-ojo ir 2-ojo pažymių konvertavimo modelio skirtumai išryškejja, konvertuojant reitinguojamą 10000 dydžio pažymių ai- 
bę. Pažymių konvertavimo neatitikimo atvejų skaičiaus priklausomybè nuo konvertuojamos pažymių aibès dydžio pavaizduota 4.17 paveiksle. Šiuo testavimo atveju gaunami teigiamų pažymių konvertavimo skirtumai taikant dviparametrị ir triparametri pažymių konvertavimo modeli, visose testuojamose vertinimo skalèse. Didejjant vertinimo skalių $A$ ir $B$ dydžių skirtumui, didejja ir vertinimų konvertavimo neatitikimų, taikant 1-ajji ir 2-aji pažymių konvertavimo modeli, skaičius.

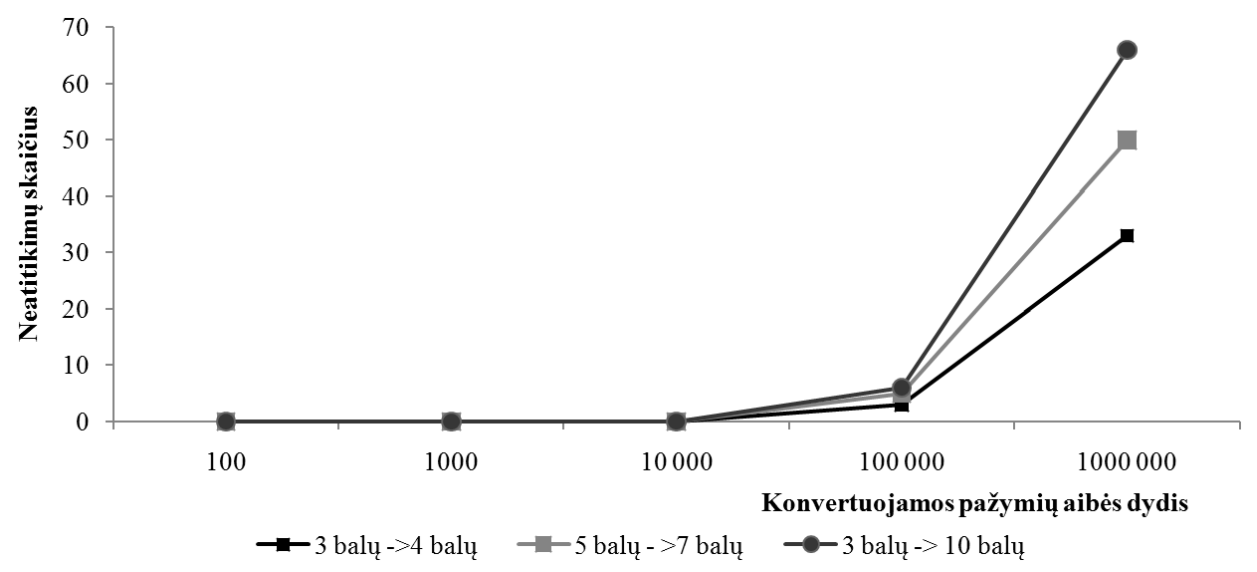

4.17 pav. 1-ojo ir 2-ojo modelio konvertavimo neatitikimo atvejai konvertuojant pažymius skirtingo dydžio vertinimo skalèse 4-uoju testavimo atveju

Fig. 4.17. The irrelevancies of conversion of first and second model, while conversion of grades is carried out on grading scales of the different size in the fourth test case

Apibendrinant pažymių konvertavimo modelių testavimo rezultatus galima teigti, kad teigiamų vertinimų konvertavimo neatitikimo atvejus sąlygoja testuojamų vertinimo skalių dydžių ir šių skalių teigiamų pažymių pasiskirstymo skirtumai. Teigiamų pažymių konvertavimo neatitikimų atvejų skaičius minimizuojamas reitinguojant studentų vertinimus. Reitinguojamos teigiamų pažymių aibės konvertavimo neatitikimų atvejų, taikant dviparametrị ir triparametrị pažymių konvertavimo modelius, skaičius tiesiogiai priklauso nuo konvertuojamos pažymių aibès dydžio.

\subsection{Ketvirtojo skyriaus išvados}

1. Dviparametrio ir triparametrio pažymių konvertavimo modelių eksperimentinis tyrimas rodo, kad teigiamų pažymių konvertavimo neatitikimo atvejus sąlygoja teigiamos vertinimo skalių dalies dydžio ir teigiamų pažymių pasiskirstymo skirtumai. 
2. Testavimo rezultatai rodo, kad tiksliam ir vienareikšmiam teigiamų pažymių konvertavimui būtinas vertinimų reitingavimas. Konvertuojant nereitinguojamos pažymiu aibès vertinimus gaunami pažymių konversijos neatitikimo atvejai vertinimo skalèse, kurių teigiamiems vertinimams skiriamas vienodas ir skirtingas balų skaičius.

3. Minimalus reitingų skaičius, užtikrinantis teigiamų pažymių konvertavimo vienareikšmiškumą, vertinimo skalèse, kurių teigiamiems vertinimams skiriamas skirtingas balų skaičius, dviparametrio ir triparametrio pažymių konvertavimo modelio atveju, yra lygus vertinimo skalès su didesniu teigiamų balų skaičiumi, teigiamos dalies dydžiui.

4. Testavimo rezultatai rodo, kad reitinguojamos pažymių aibės konvertavimo skirtumai, taikant dviparametrị ir triparametri pažymių konvertavimo modeli, gaunami ženkliai didèjant konvertuojamos pažymių aibès dydžiui. 



\section{Pažymių konvertavimo modelio integravimas i e. mokymosi sistemas}

E. mokymosi sistemos turi atitikti šiandienines e. mokymosi rezultatų vertinimo kaitos tendencijas. Mokymosi be sienų idejai igyvendinti, jungtinėms studijoms plètoti būtinas pažymių konvertavimo modelio integravimas ị e. mokymosi sistemas. Studentų studijų rezultatai turi būti pateikiami jų šalies, institucijos studijų rezultatų vertinimo skalejje - tik tuomet vertinimas teiks išsamią grižtamają informaciją.

Todèl tęsiant eksperimentinị tyrimą, kuriamas ir ị e. mokymosi sistemą integruojamas pažymių konvertavimo modulis. Skyrelyje pagrindžiamas eksperimentinès e. mokymosi sistemos pasirinkimas, analizuojamas kuriamo modulio funkcionalumas, parenkamas pažymių konvertavimo algoritmas, aptariami sukurto modulio integravimo klausimai, nagrinejjamos pažymių konvertavimo modulio kompleksinio panaudojimo e. mokymosi procese galimybès. 


\subsection{E. mokymosi sistemos parinkimas}

Literatūroje terminas e. mokymosi sistema (E-learning system (ELS)) bendrąja prasme naudojamas norint ịvardyti bet kurią iš toliau išvardytų sistemu ar jų derinị: mokymo valdymo sistemą (Learning Management System (LMS)), turinio valdymo sistemą (Content Management System (CMS)), mokymo turinio valdymo sistemą (Learning Content Management System (LCMS)). Pasak S. Irlbeck ir J. Mowat (2007) turinio valdymo sistemų tikslas - saugoti ir teikti mokymosi turinị. J. Falla (2002) turinio valdymo sistemą apibrèžia kaip technologijų visumą, igalinančią struktūrizuotos ir/arba nestruktūrizuotos informacijos saugojimą, pateikimą, valdymą bei bendrą naudojimą. Pasak M. Nichani (2002), turinio valdymo sistema yra duomenų saugykla, kurioje yra integruoti turinio valdymo, pakavimo, eiliškumo nustatymo įrankiai. S. Irlbeck ir J. Mowat (2007) pabrèžia, kad svarbus turinio valdymo sistemų bruožas - e. mokymosi kursų sudarytų iš mokymosi objektų, kuriuos galima pakartotinai panaudoti įvairiuose mokymosi kontekstuose, teikimas.

Mokymo valdymo sistemos (LMS) skirtos mokymo procesams valdyti (Irlbeck et al. 2007). Šiose sistemose integruotos priemonès automatizuoja procesus, susijusius su kursų informacijos saugojimu, valdymu, mokymo programų sudarymu, studentų pažangos stebèjimu (Nichani 2002). Taigi mokymo valdymo sistemos - tai programine įranga, kuri automatizuoja mokymo įvykių administravimą (Jurubescu 2008).

Dar viena e. mokymosi sistemų rūšis - mokymo turinio valdymo sistemos. Šių sistemų tikslas - mokymo turinio, mokymosi objektų valdymas, didinant mokymo efektyvumą (Jurubescu 2008). Pasak S. Irlbeck ir J. Mowat (2007), mokymo turinio valdymo sistemos apima dali mokymo valdymo sistemų ir turinio valdymo sistemų funkcijų. Skirtingai nuo mokymo valdymo sistemų, valdymas mokymo turinio valdymo sistemose gali vykti ne tik kurso, bet ir mokymosi objekto lygmenyje (Qwaider et al. 2010).

S. Irlbeck ir J. Mowat (2007) apibendrino e. mokymosi sistemų funkcijas, išskirdami savybes, būdingas kiekvienai e. mokymosi sistemų grupei. 5.1 lentelejje aprašytos turinio valdymo sistemoms, mokymo valdymo sistemoms ir mokymo turinio valdymo sistemoms būdingoms savybès. Autoriai kiekvieną e. mokymosi sistemos funkciją vertino trimis lygmenimis: tvirtai išvystyta $(T)$, dalinai išvystyta (D) ir nebūdinga funkcija. 
5.1 lentelè. CMS, LMS ir LCMS savybès (Irlbeck et al. 2007)

Table 5.1 Features of CMS, LMS and LCMS (Irlbeck et al. 2007)

\begin{tabular}{|c|c|c|c|}
\hline \multirow{2}{*}{ Savybès } & \multicolumn{2}{c|}{ Funkcionalumas T - tvirtai, } \\
\cline { 2 - 4 } & CMS - dalinai \\
\hline Studentų valdymas & & LMS & LCMS \\
\hline Turinio valdymas & $\mathrm{T}$ & & $\mathrm{T}$ \\
\hline Turinio kūrimas & $\mathrm{D}$ & & $\mathrm{T}$ \\
\hline Kursų katalogas & & $\mathrm{T}$ & $\mathrm{T}$ \\
\hline Registracijos sistema & & $\mathrm{T}$ & $\mathrm{D}$ \\
\hline Kompetencijų valdymas & & $\mathrm{T}$ & $\mathrm{D}$ \\
\hline Vykdyti ir stebėti mokymąsi & & $\mathrm{T}$ & $\mathrm{D}$ \\
\hline Vertinamų veiklų kūrimas, vertinimas ir grịž- & & $\mathrm{T}$ & $\mathrm{T}$ \\
\hline tamasis ryšys & & & $\mathrm{T}$ \\
\hline Paieška mokymosi objektų saugykloje & $\mathrm{T}$ & $\mathrm{D}$ & $\mathrm{T}$ \\
\hline Bendradarbiavimas/Sinchroninès mokymosi & & & $\mathrm{T}$ \\
\hline priemonès & & $\mathrm{T}$ & \\
\hline
\end{tabular}

Šio darbo tyrimo objektas - automatinis pažymių konvertavimas iš vienos studijų rezultatų vertinimo skalès i kitą, todèl šiame darbe e. mokymosi sistemos sąvoka naudojama mokymo valdymo sistemos ir mokymo turinio valdymo sistemos prasme. Pastarųu metų e. mokymosi sistemų taikymo studijose tyrimai rodo, kad populiariausia e. mokymosi sistema - Moodle. Moodle sistema priskiriama mokymo turinio valdymo sistemoms (Nedeva 2005). 2009 metais atlikto e. mokymosi sistemų taikymo pasaulio universitetuose tyrimas rodo, kad Moodle sistemą naudoja net 36 proc. tyrime dalyvavusių universitetų, antroji pagal populiarumą - BlackBoard sistema, ją pasirinkę 23 proc. universitetų, o trečiojoje pozicijoje - Sakai sistema - 20 proc. universitetų (Ermalai et al. 2009). 2010 metais LieDM koordinacinio centro organizuota aukštujų mokyklų apklausa parodè, kad populiariausia e. mokymosi sistema Lietuvoje - Moodle, šią sistemą naudoja 18 aukštụjų mokyklų, Blackboard - 14 aukštujų mokyklų, Sakai - 2 aukštosios mokyklos, ATutor - 1 aukštoji mokykla (Rutkauskienè et al. 2010).

Kadangi atvirojo kodo sistemas pritaikyti savo poreikiams yra paprasčiau, jų ištekliai nèra uždari, todèl e. mokymosi sistema eksperimentiniam tyrimui atlikti buvo renkama iš Lietuvoje naudojamų atvirojo kodo sistemų grupés. I analizuojamų e. mokymosi sistemų sąrašą įtraukiamos trys nemokomos, skir- 
tingos paskirties ir populiarumo Lietuvoje sistemos: Moodle, ATutor, Sakai. Moodle sistema plačiai naudojama Lietuvos ir pasaulio aukštosiose mokyklose (Mačiulskis et al. 2011). Sakai sistema užima žymią vietą pasaulyje, tačiau Lietuvoje praktiškai nenaudojama (Mačiulskis et al. 2011). Sakai diegimo tyrimai pradèti Šiaulių universitete (Mačiulskis et al. 2010). ATutor sistema nèra populiari Lietuvos aukštosiose mokyklose, tačiau taikoma Lietuvos pagrindinėse mokyklose ir gimnazijose. Šios sistemos pagrindu 2006 metais sukurta Mokyklu tobulinimo programos virtuali mokymosi aplinka (Dagienè et al. 2008).

Renkantis e. mokymosi sistemą eksperimentiniam tyrimui atlikti, vertinamas ne tik sistemos populiarumas Lietuvos aukštosiose mokyklose, bet ir sistemos pritaikymo naudotojo poreikiams galimybès. Tiek Lietuvoje, tiek pasaulyje atlikta visa aibė tyrimų, vertinančių e. mokymosi sistemas. 2005 metais S. Graf, B. List atliko devynių atvirojo kodo sistemų pritaikomumo vertinimą. Tyrimo metu buvo vertinamos ir nagrinejjamos sistemos: Moodle, ATutor, Sakai. Autoriai nagrinejo sistemu pritaikymo institucijos poreikiams galimybes (Adaptability), individualizavimą (Personalization), ištęsiamumo, pletros galimybes (Extensibility), turinio pritaikomumą (Adaptivity). Geriausiai iš nagrinèjamų sistemų buvo ivertinta Moodle sistema. A. Al-Ajlan, H. Zedan (2008) atliko lyginamają analizę Moodle, Blackboard, Angel, eCollege, Claroline, Dokeos ir Sakai sistemų. Autoriai lygino nagrinejjamų sistemų technines ir taikomąsias savybes. Autorių nuomone, Moodle ir Sakai taikomuoju aspektu funkcionaliausios e. mokymosi sistemos. E. Kurilovas (2007) parengè e. mokymosi aplinkų techninio vertinimo kriterijus. Remiantis šiais kriterijais vertinama e. mokymosi sistemų architektūra, sąveikumas, internacionalizavimo ir lokalizavimo galimybès, prieinamumas ir pritaikomumas. E. Kurilovo, V. Dagienès (2010) e. mokymosi sistemu vertinimo rezultatai rodo, kad Moodle lyginant su ATutor, Ilias sistemomis yra kokybiškiausia techniniu požiūriu sistema.

Taigi eksperimentiniam tyrimui pasirinkta Lietuvoje populiari, techniniu požiūriu kokybiškiausia iš Lietuvoje naudojamų atvirojo kodo sistemų e. mokymosi sistema-Moodle.

\subsection{Pažymių konvertavimo modulio funkcionalumas e. mokymosi sistemoje}

Pažymių konvertavimo modulis yra skirtas e. mokymosi sistemos funkcijoms praplèsti, vertinimams konvertuoti ị besimokančiųų institucijos studijų rezultatu vertinimo skalę. Kuriamo modulio paskirtis, funkcionalumas ir santykis su vartotojais (studentu, dėstytoju ir administratoriumi) aprašytas panaudos atvejų diagrama (5.1 pav.). 


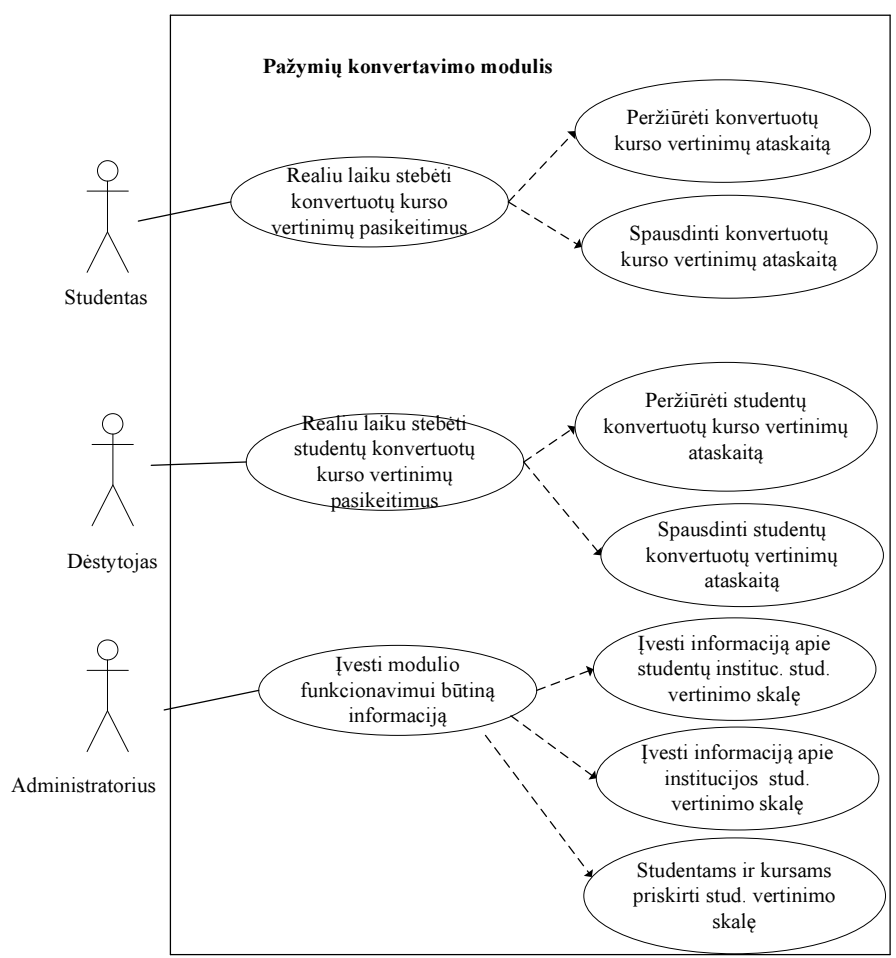

5.1 pav. Pažymių konvertavimo modulio panaudos atvejų diagrama

Fig. 5.1. Use Case model of grades transfer module

Pažymių konvertavimo modulio naudotojai yra studentas, dèstytojas ir administratorius. Studentas kurso studijų metu gali nuolat stebėti kurso vertinimų pasikeitimus. Kurso vertinimai yra pateikiami studijų rezultatų vertinimo skalèje, kurioje vykdomos studijos bei institucijos, kuriai priklauso studentas vertinimo skalejje. Pateikti vertinimai dviejose studijų rezultatų vertinimo skalèse teikia išsamią grižtamają informaciją studentui, kuris gali realiai vertinti pasiektus mokymosi rezultatus. Kurso dèstytojas taip pat gali stebèti studentų vertinimų pasikeitimus ir teikti aukštojo mokslo institucijoms išsamias ataskaitas apie jų mokymosi pasiekimus.

Administratorius vykdo informacijos, kuri yra būtina korektiškam modulio funkcionavimui, îvedimą. Pažymių konvertavimo moduliui būtina informacija apie institucijos, kurioje vykdomos studijos bei studento institucijos studijų rezultatų vertinimo skales. Pažymių konvertavimas vykdomas tik tuomet, jei kursui ir studentui yra priskirtos vertinimo skalès ir šios vertinimo skalès nesutampa. 
Pažymių konvertavimo modulis praplečia Moodle sistemos funkcijas. Pažymių konvertavimas tampa vertinimo proceso dalimi. Pažymių konvertavimo funkcijos vykdymo seką detalizuoja darbų sekos modelis (5.2 pav.). Tam, kad studentui būtų pateikti konvertuoti pažymiai, administratorius įveda informaciją, būtiną pažymių konvertavimo moduliui funkcionuoti. Kurso dèstytojas apibrěžia vertinamas veiklas, formuoja kurso dienyną - išskiria vertinimų grupes ir parenka šių grupių apibendrinimo metodą, apibrèžia kurso galutini pažymị. Kadangi studentai reitinguojami grupès lygmenyje, vykdomas studentu grupavimas. Studentui atlikus vertinamas veiklas, vykdomas vertinimo procesas. E. mokymosi sistemu vertinamos veiklos pagal ịvertinimo būdą yra skirstomos i automatiškai ir neautomatiškai vertinamas veiklas. Automatiškai vertinamas veiklas įvertina sistema. Studentui atlikus automatiškai vertinamą veiklą, iš karto pateikiamas jo žinias ir gebejjimus įvertinantis pažymys. Neautomatiškai vertinamas veiklas vertina kurso dėstytojas. Vertinimų pasikeitimas inicijuoja pažymių konvertavimą.

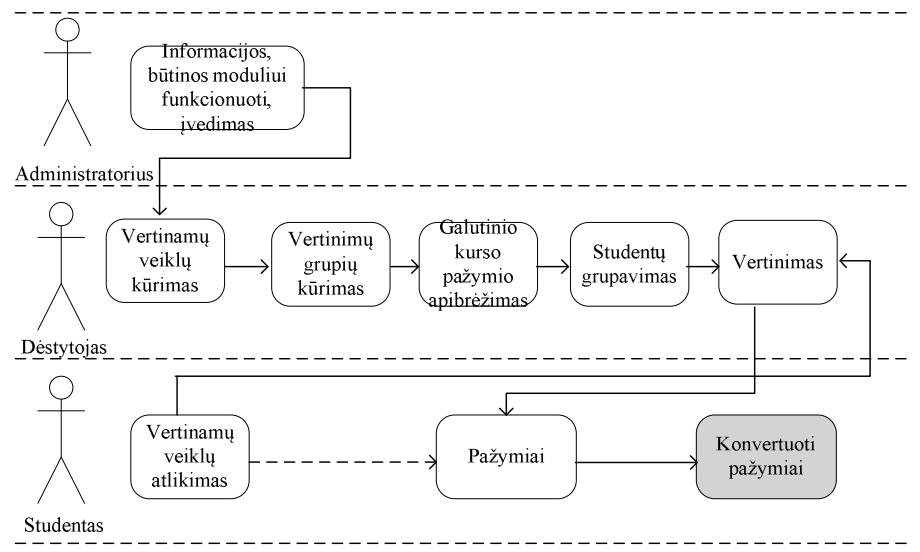

5.2 pav. Pažymių konvertavimo darbų sekų modelis

Fig. 5.2. Workflow model of grades transfer

\subsection{Pažymių konvertavimo modelio parinkimas}

Dviparametrio ir triparametrio pažymių konvertavimo modelių eksperimentinis tyrimas parodè, kad abiejų vertinimų konvertavimo modelių pažymių konvertavimo rezultatai reitinguojamoje vertinimų aibejje sutampa. Pažymių konversijos neatitikimo atvejai gaunami tik ženkliai didejant konvertuojamos pažymių aibès dydžiui. Atliktas dviparametrị ir triparametrị pažymių konvertavimo modeli atitinkančiu algoritmų sudètingumo vertinimas parodè, kad triparametris pažymių konvertavimo modelio algoritmas realizuojamas didesniu veiksmų 
skaičiumi. Triparametrio modelio algoritmas apytiksliai daugiau nei 2 kartus sudètingesnis nei dviparametrio pažymių konvertavimo modelio algoritmas.

Triparametrio pažymių konvertavimo modelio atveju dvimačio tikimybinio skirstinio - vertinimu konvertavimo lentelès formavimas priklauso nuo konvertuojamos pažymių aibès. Tuo tarpu dviparametris pažymių konvertavimo modelis vertinimų konvertavimo lentelę formuoja neatsižvelgiant ị konvertuojamos pažymių aibės duomenis. Atlikus kuriamo modulio funkcionalumo analizę pastebėta, kad pažymių konvertavimas inicijuojamas kiekvieną kartą, pasikeitus studentų pažymiams. Konvertuojant pažymius triparametrio pažymių konvertavimo modelio algoritmu, kiekvieną kartą, vykdant vertinimų perskaičiavimus, sudaroma pažymių konvertavimo lentelè. Taigi ši modelị atitinkančio algoritmo sudètingumas, integruojant ji i c e. mokymosi sistemas, dideja. Dviparametrio pažymių konvertavimo modelio atveju pažymių konvertavimo lentelès performavimas nèra būtinas.

İvertinus dviparametrio ir triparametrio pažymių konvertavimo modelių tinkamumą pažymiams e. mokymosi sistemoje konvertuoti, pasirinktas dviparametris pažymių konvertavimo modelis. Dviparametrio pažymių konvertavimo modelio algoritmo pagrindu sudaromas pažymių konvertavimo modulis.

\subsection{Pažymių konvertavimo modelio integravimas i Moodle sistemą}

Eksperimentiniam tyrimui pasirinkta Moodle 2.2.1 versija. Lyginant Moodle 1.9.x ir 2.x versijas, ženklius pasikeitimus galima įžvelgti virtualios mokymosi aplinkos navigacineje sistemoje, patobulintas Moodle sistemos vertinimų dienynas. Analizuojant Moodle sistemos pritaikymą ìvairių šalių studentams galima išskirti Moodle sistemoje realizuotą daugiakalbès vartotojų sąsajos funkciją, igalinančią sistemos naudotojus rinktis Moodle svetainès naudotojo sąsajos kalbą. Sistemoje numatytas įvairių vertinimo skalių taikymas, naujų vertinimo skalių kūrimas, tačiau neišspręsta vertinimų konvertavimo pagal studentų institucijos studijų rezultatų vertinimo skalę problema. Integruojant pažymių konvertavimo modeli, Moodle sistema internacionalizuojama, pritaikant e. mokymosi sistemą jungtinių e. mokymosi kursų teikimui. Dviparametrio pažymių konvertavimo modelio algoritmas integruojamas ì Moodle sistemą, sukuriant atskirą Moodle sistemos modulį. Pažymių konvertavimo modulis - tai Moodle sistemos įskiepis, sukurtas laikantis Moodle sistemos įskiepių kūrimo taisyklių, metodų, atitinkantis Moodle iskiepių technologijas. Šiam moduliui realizuoti taikytos PHP, HTML, MySQL, CSS technologijos. Moodle sistemoje integruojama pažymių konvertavimo funkcija, išplečiant Moodle vertinimų dienyno funkcijas, pride- 
dant naują vertinimų dienyno ataskaitos modulį. Pažymių konvertavimo modulio integravimo ị Moodle sistemą komponentų diagrama pateikta 5.3 paveiksle.

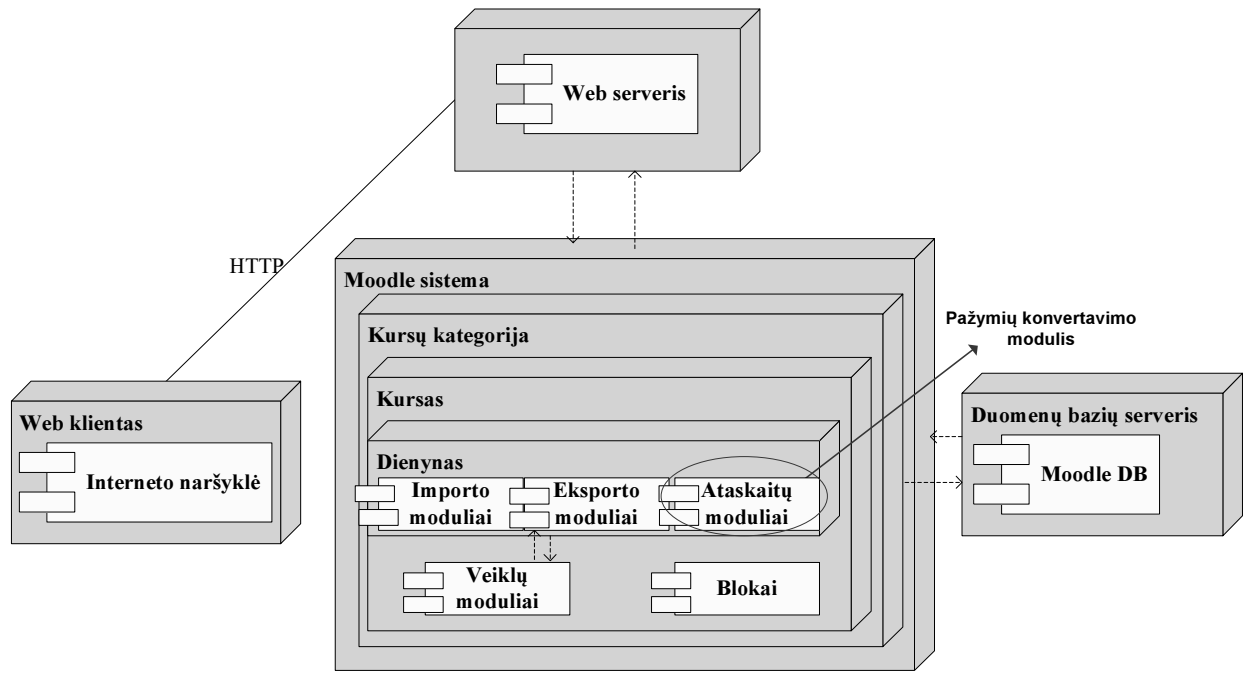

5.3 pav. Pažymių konvertavimo modulio integravimo ị Moodle sistemą komponentų diagrama

Fig. 5.3. Grades transfer module integration into Moodle system components diagram

Pagrindiniai naujojo Moodle vertinimų dienyno ataskaitos modulio failai aprašyti žemiau pateiktoje lentelèje. Atskiri modulio failai yra skirti modulio funkcionalumui, stiliui, modulio nuostatoms aprašyti, duomenų bazès struktūrai atnaujinti, prieigos kontrolei nurodyti.

5.2 lentelè. Pagrindiniai pažymių konvertavimo modulio failai

Table 5.2. The main files of grades transfer module

\begin{tabular}{|c|c|}
\hline \multicolumn{2}{|c|}{ Pažymių konvertavimo modulis } \\
\hline Failo pavadinimas & Aprašymas \\
\hline 1 & 2 \\
\hline index.php & Pagrindinis modulio failas. \\
\hline lib.php & $\begin{array}{c}\text { Modulio bibliotekos failas. Šiame faile aprašomos funkcijos, } \\
\text { kurios yra būtinos integruojant moduli i Moodle sistemą, taip } \\
\text { pat funkcijos, aprašančios modulio veikimą. }\end{array}$ \\
\hline styles.css & $\begin{array}{c}\text { Modulio stilių aprašantis failas. Modulio stilius aprašomas, } \\
\text { naudojant CSS taisykles. }\end{array}$ \\
\hline
\end{tabular}


5.2 lentelès tẹsinys

\begin{tabular}{|c|c|}
\hline 1 & 2 \\
\hline settings.php & Modulio nuostatas apibrèžiantis failas. \\
\hline version.php & Šiame faile saugoma modulio versija. \\
\hline db/access.php & $\begin{array}{c}\text { Šiame faile apibrèžiamos modulio naudojimo galimybės. } \\
\text { Taikant šiame faile aprašytas galimybes, Moodle vaidme- } \\
\text { nims apibrěžiama modulio prieigos kontrolè. }\end{array}$ \\
\hline db/upgrade.php & Šiame faile aprašomas duomenų bazės atnaujinimas. \\
\hline
\end{tabular}

Išplečiant Moodle vertinimu dienyno funkcionalumą atnaujinamas Moodle bibliotekos failu lib/grade/grade_grade.php, lib/grade/constants.php, lib/gradelib.php turinys, keičiami kalbos failai /lang/en/grades.php, llang/en/moodle.php, atnaujinami failai /course/edit_form.php, user/editadvanced_forms.php, naujais failais papildomas Moodle grade katalogo pakatalogis edit.

Studentu ịvertinimai Moodle sistemoje saugomi vertinimu dienyne. Pasiekti mokymosi rezultatai vertinami, taikant vertinimo skales. Moodle sistema turi 100 skirtingų skaitinių vertinimo skalių, kurios negali būti keičiamos ir vieną raidinès vertinimo skalès pavyzdi (Cole et al. 2008). Skaitinès vertinimo skalès pasirenkamos nurodant maksimalų skalès balą. Naujos vertinimo skalès Moodle sistemoje gali būti kuriamos dėstytojų, administratoriaus ir visų sistemos naudotojų, kuriems priskirtos vertinimo skalių valdymo teisès (Cole et al. 2008). Vertinamos veiklos automatiškai yra įkeliamos ị kurso dienyną. Šios veiklos dienyne yra grupuojamos, kiekvienai grupei skaičiuojamas apibendrinamasis vertinimas, apibrežiama galutinio pažymio skaičiavimo formulè, nurodoma vertinimo skalè, nustatomas minimalus teigiamas vertinimas.

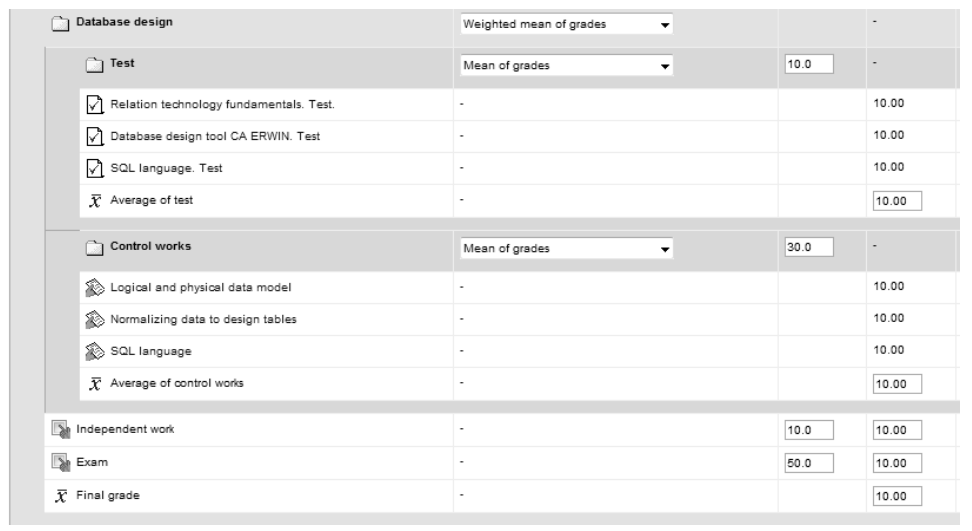

5.4 pav. Vertinimų dienyno formavimas Moodle sistemoje

Fig. 5.4. Formation of gradebook in Moodle 
Kurso dienynas organizuojamas hierarchijos principu (5.5 pav.). Šios hierarchijos viršūnejje yra galutinis kurso pažymys. Vertinamos veiklos yra grupuojamos, kiekvienai grupei parenkant vertinimo skalę, nurodant apibendrinimo metodą ir/arba nustatant galutinio grupès vertinimo skaičiavimo formulę. Kurso galutinis pažymys formuojamas parenkant vertinimo skalę, apibendrinimo metodą ir/arba galutinio pažymio skaičiavimo formulę. Moodle sistema siūlo įvairias pažymių kaupimo strategijas (Mačiulskis et al. 2010). Be vidurkio skaičiavimo, atsižvelgiant ì pažymių svorị yra siūlomas paprastas vidurkis, mediana, ivertinimų suma ir kitos (Mačiulskis et al. 2010). Parenkant apibendrinimo metodą Weighted mean of grades, realizuojama kaupiamojo vertinimo sistema.

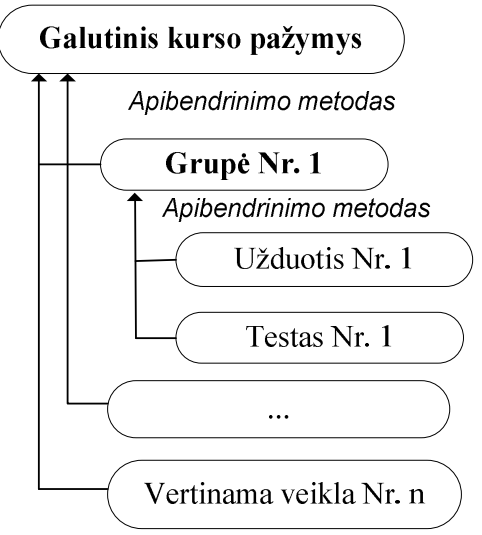

5.5 pav. Pažymių hierarchija vertinimų dienyne

Fig. 5.5. Hierarchy of grades in gradebook

Moodle sistemoje šalia įprasto vertinimo galima taikyti vertinimą pagal pasiektus mokymosi rezultatus. Kursui apibrèžus mokymosi rezultatus, atskiroms kurso veikloms priskiriamas vertinimas pagal pasiektus mokymosi rezultatus. Vertinimų dienyne studentas gali stebèti detalizuotą vertinimą pagal apibrèžtus mokymosi rezultatus.

Vertinimo procesas yra gaunamas Moodle sistemos duomenu bazeje. Moodle 2.1.1 versijos duomenų bazę sudaro 288 lentelių. Kaip pažymi S. Žemaitis (2009), Moodle duomenų bazès struktūra nèra gerai dokumentuota. Moodle vertinimų dienyno pagrindinių lentelių loginè schema pateikta 5.6 paveiksle. Lenteleje $m d l$ grade_categories saugoma informacija apie vertinimu grupes, kurios formuoja galutinị kurso pažymį. Lentelèje $m d l$ grade_items saugomi visi vertinimų dienyno elementai. Šios lentelès išorinis raktas course $i d$ susieja vertinamas veiklas su konkrečiu e. mokymosi kursu, o išorinis raktas categoryid vertinamą veiklą priskiria konkrečiai vertinamų veiklų grupei. Vertinama veikla, kurios laukas categoryid igyja reikšmę NULL, o laukas itemtype - reikšmę course, atitinka galutini kurso pažymį. Skaitinè vertinimo skalè apibrèžiama 
laukuose grademax, grademin, gradepass. Lenteleje $m d l$ grade_grades saugoma informaciją apie studentų gautus pažymius. Šios lentelès išorinis raktas user_id susieja vertinimus su konkrečiu studentu, o išorinis raktas item_id su vertinama veikla. Studentui vertinimų dienyne pateikiami pažymiai saugomi lauke finalgrade. Mokymosi rezultatų vertinimo istorija gaunama lentelèse mdl_grade_categories_history, mdl_grade_grades_history, mdl_grade_items_history. Importuotu vertinimu duomenys saugomi mdl_grade_import_newitem, $m d l$ grade_import_values lentelèse.

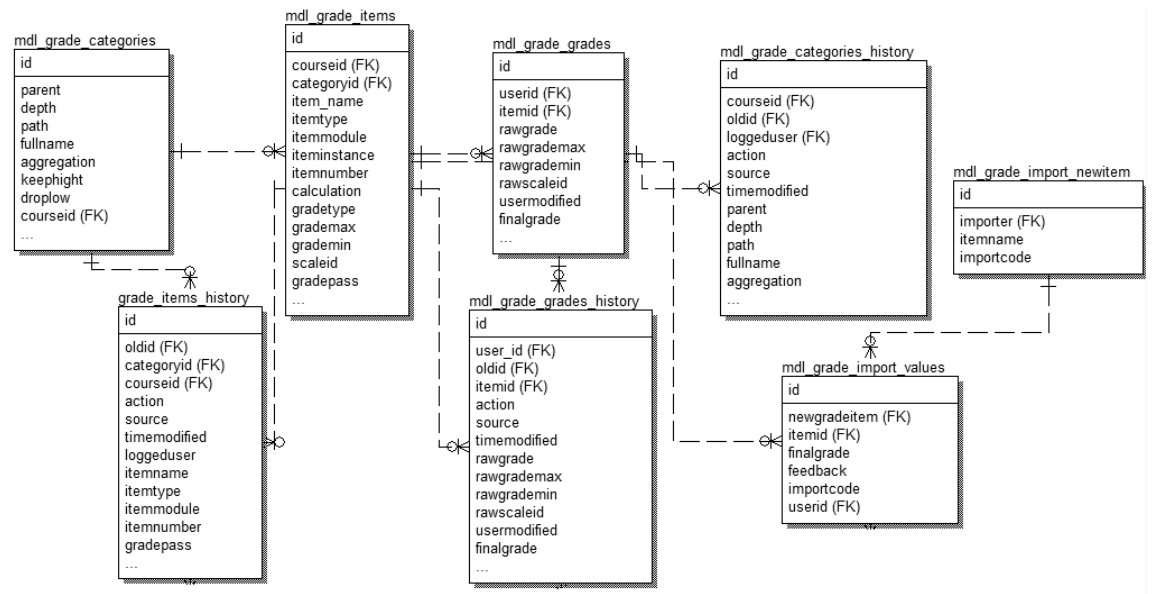

5.6 pav. Pagrindinių vertinimų dienyno lentelių loginè schema

Fig. 5.6. Logical scheme of the main tables of gradebook

Integruojant pažymių konvertavimo modulio duomenų bazès schemą i bendrą Moodle duomenų bazès struktūrą, kuriamos naujos ir atnaujinamos jau egzistuojančios duomenų bazès lentelès. Pažymių konvertavimo modulio duomenų bazès loginè schema pateikta 5.7 paveiksle. Moodle duomenų bazès struktūra papildoma trimis naujomis lentelemis: mdl_gradetransfer_scale, mdl_gradetransfer_scale_detail, mdl_gradetransfer_matrix. Šiose lentelèse saugoma informacija apie studento institucijos studijų rezultatų vertinimo skalę, šios studijų rezultatų vertinimo skalès teigiamų pažymių pasiskirstymą, suformuotos pažymių konvertavimo lentelès duomenys. Atnaujinamos ir lentelès mdl_user, mdl_course, papildant šias lenteles išoriniu raktu home_scaleid. Konvertuoti kurso pažymiai saugomi lentelès $m d l$ grade_grades naujame lauke transfergrade. 


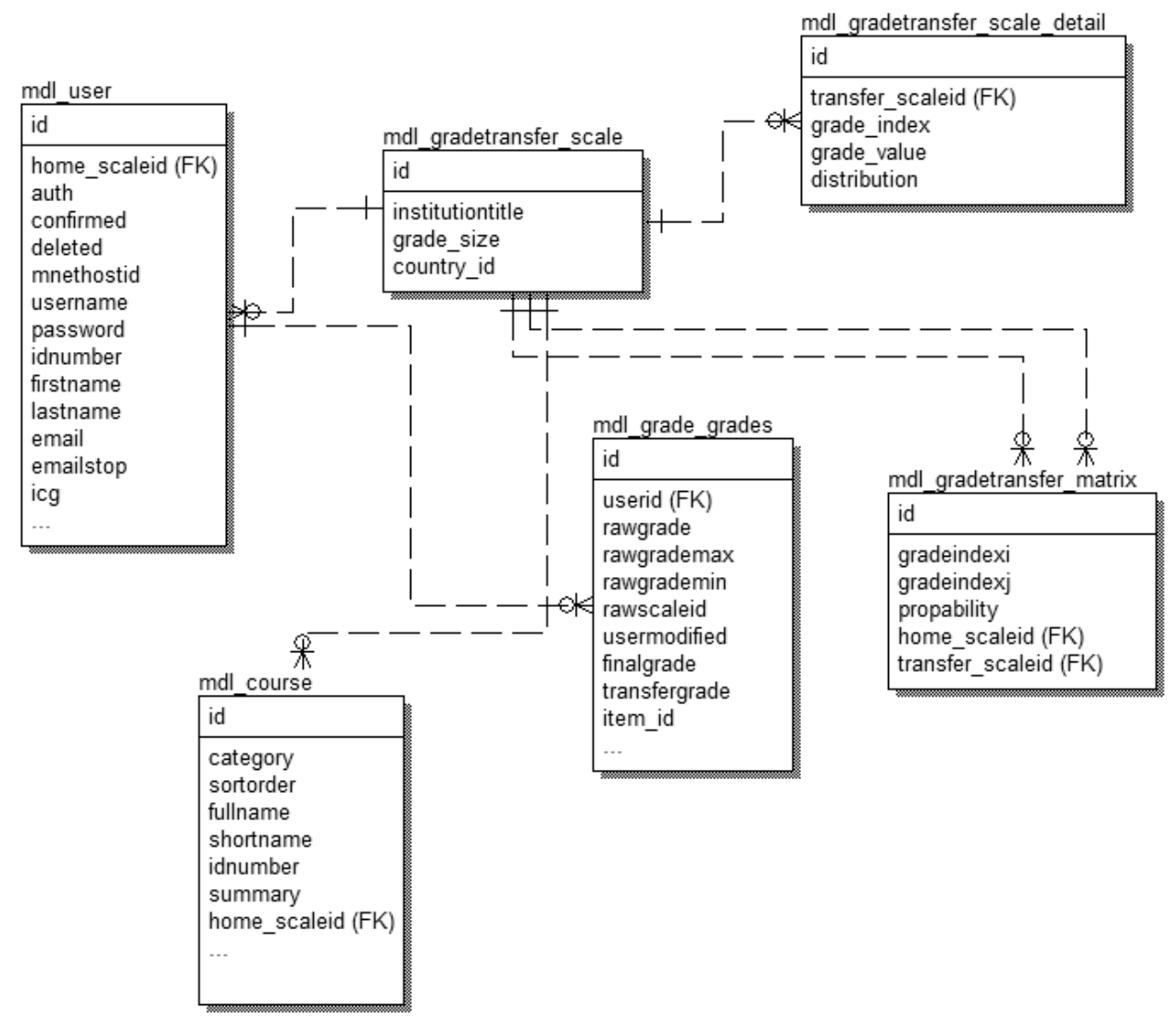

5.7 pav. Pažymių konvertavimo modulio duomenų bazės loginė schema

Fig. 5.7. Logical database scheme of grades transfer module

Moodle sistemos naudotojai skirtinguose kontekstuose gali igyti skirtingus vaidmenis. Standartiškai Moodle sistemoje apibrèžiamos 7 vaidmenų grupès: administratorius, kursų kūrèjas, dėstytojas, dèstytojas be redagavimo, studentas, svečias, autorizuotas naudotojas, tačiau sistemos administratorius gali papildyti standartinį vaidmenu sąrašą įvesdamas naujus sistemos vaidmenis (Cole et al. 2008).

Moodle sistemos kontekstinis modelis pavaizduotas žemiau pateiktame paveiksle. Moodle sistemoje skiriami ịvairūs kontekstų tipai: sistemos, kursų kategorijos, kursu, modulio, bloko, naudotojo (5.8 pav.). Moodle sistema organizuojama hierarchijos principu. Teisès, priskirtos žemesnio lygio kontekstui, automatiškai perrašomos aukštesnio hierarchinio lygio kontekstui (Mandal 2011). 


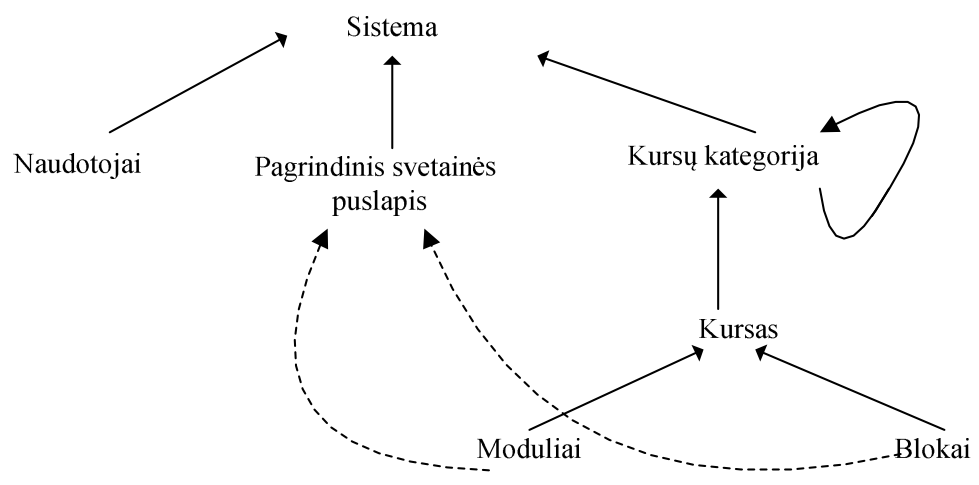

5.8 pav. Moodle sistemos kontekstinis modelis

Fig. 5.8. Moodle contex model

Pažymių konvertavimo modulio prieigos kontrolè administratoriaus, studento, desstytojo ir dėstytojo be redagavimo vaidmeniui apibrèžiama/db/access.php faile. Apibrèžiant naujos vertinimų dienyno ataskaitos peržiūros galimybes gradereport/user_new:view, konstantai captype parenkama read reikšmé, apibrèžiamas konteksto lygmuo 'contextlevel' => CONTEXT_COURSE, kiekvienam vaidmeniui priskiriamas prieigos kontrolès tipas $C A P A \overline{L L O W}$.

Integruojant pažymių konvertavimo modeli i Moodle sistemą, išlaikomi bendri Moodle modulių kūrimo principai. Pagrindinis pažymių konvertavimo modulio failas - index.php. Šiame faile pirmiausia nuskaitomi konfigūracijos parametrai, itraukiamos reikalingos bibliotekos, atliekamas prieigos kontrolès sąlygų tikrinimas, vykdomas vertinimu skaičiavimas, konvertavimas, formuojama naudotojo prieigos teises atitinkanti ataskaita arba išvedamas klaidos pranešimas. Naujos vertinimų dienyno ataskaitos konfigūracija apibrēžiama settings.php faile. Administratoriaus parinktu konfigūracijos parametrų pagrindu formuojama vertinimu dienyno su konvertuotais vertinimais ataskaita. Moodle sistema pasižymi gerai išvystytomis bibliotekomis. Vertinimų dienyno ataskaitos moduliui reikalingos funkcijos apibrěžtos /gradelib.php, /grade/lib.php, /grade/report/user_new/lib.php failuose.

Pažymių konvertavimo modulio pagrindinio failo veiksmų sekos atlikimo veiklos diagrama pateikta 5.9 paveiksle. Pažymių konvertavimo modulis išplečia vertinimų dienyno funkcionalumą. Vertinimų konvertavimo funkcija lanksčiai integruojama ị bendrą vertinimų dienyno pažymių formavimo procesą. Vertinimų dienyno pažymiai saugomi lentelès $m d l$ grade grades lauke finalgrade, o konvertuoti vertinimai lauke transfergrade. Pažymių perskaičiavimas vykdomas, pasikeitus vertinimams vertinamų veiklų moduliuose arba atnaujinus pažymius kurso vertinimų dienyne. Vykdant vertinimų perskaičiavimą, keičiami ne tik atnaujinti pažymiai, bet ir visi su šiuo pažymiu susiję vertinimai. 


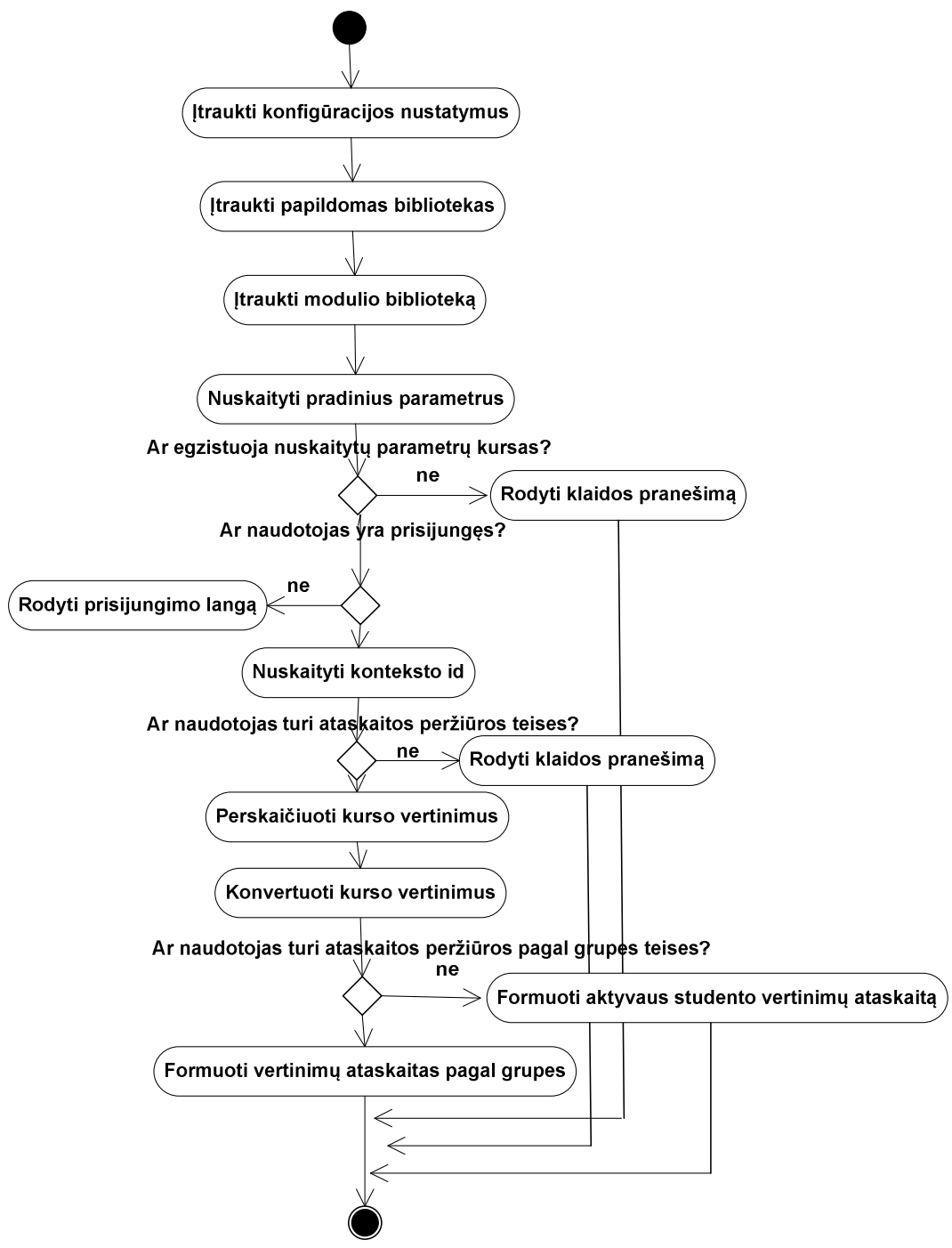

5.9 pav. Pažymių konvertavimo modulio veiklos diagrama

Fig. 5.9. Activity diagram of grades transfer module

Lentelès $m d l$ grade grades lauke rawgrade saugomi vertinimai, automatiškai įkelti iš įvairių vertinamų veiklų modulių. Vykdant vertinimų perskaičiavimą, lauko rawgrade reikšmé perrašoma i finalgrade lauką. Vertinimų dienyne ivesta arba pakoreguota reikšmè saugoma finalgrade lauke. Pažymių koregavimas fiksuojamas lentelès $m d l$ grade grades lauke overridden, išsaugant vertinimo koregavimo datą. Vykdant pažymių perskaičiavimą, atrenkamos grupės, kurių studentų pažymiai yra perskaičiuojami. Pažymių konvertavimas vykdomas 
tik atrinktu grupių studentams. Perskaičiuojant vertinimų dienyno pažymius tikrinamos vertinimų dienyno elementų pažymių pateikimo sąlygos. Vertinimų dienyno elementams galima nustatyti ịvairias pažymių pateikimo sąlygas. Tarkime, vertinimų dienyno elemento pažymiai turi būti paslepiami iki tam tikros datos. Vertinimų dienyno elementų, netenkinančių pažymių pateikimo sąlygų, pažymiai nèra perskaičiuojami. Vertinimų dienyno pažymių perskaičiavimo procesą detalizuoja 5.10 paveiksle pateikta vertinimų perskaičiavimo veiklos diagrama.

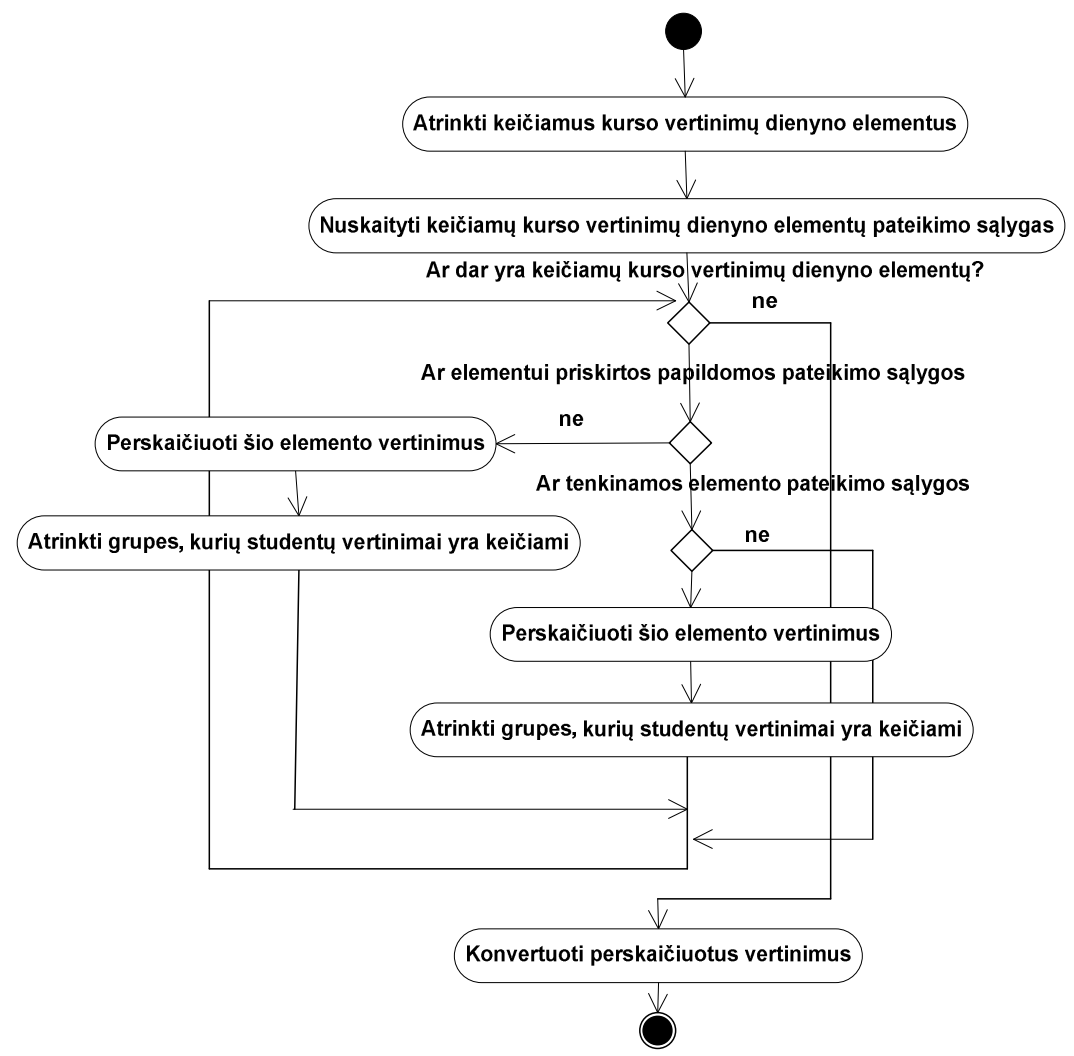

5.10 pav. Vertinimų dienyno pažymių perskaičiavimo veiklos diagrama

Fig. 5.10. Activity diagram of gradebook's grade calculation

Perskaičiavus vertinimus, vykdomas pažymių konvertavimas. Pradiniame pažymių konvertavimo etape patikrinamos būtinos pažymių konvertavimo sąlygos, t. y. nustatoma, ar kursui yra priskirta vertinimo skalè, ar yra keičiamų kurso vertinimų dienyno elementų. Jei tenkinamos būtinos pažymių konvertavimo sąlygos, tuomet atrenkami studentai, kuriems turi būti konvertuojami pažymiai. Atrenkant studentus tikrinama, ar studentui priskirta vertinimo skalès, kuri nesu- 
tampa su kurso vertinimo skale, ar studentas priklauso grupei, kurios studentu pažymiai buvo perskaičiuoti. Jei studentų, tenkinančių apibrèžtas pažymių konvertavimo sąlygas, sąrašas yra tuščias, tuomet pažymių konvertavimo procesas yra nutraukiamas.

Atrinkus studentus, tikrinama, ar suformuotos reikalingos pažymių konvertavimo lentelès. Jei lentelèje $m d l$ gradetransfer_matrix nèra saugoma kurso ir studento vertinimo skales atitinkanti pažymių konvertavimo lentelè, tuomet vykdomas šios lentelès suformavimo metodas. Konvertuojami tik tie keičiamų vertinimo dienyno elementų pažymiai, kurie priklauso atrinktiems studentams. Sudarant vertinimu pasiskirstymo pagal reitingus lenteles, reitingavimas vykdomas grupés lygmenyje. Vertinimų dienyno pažymių konvertavimo procesą detalizuoja 5.11 paveiksle pateikta vertinimų konvertavimo veiklos diagrama.

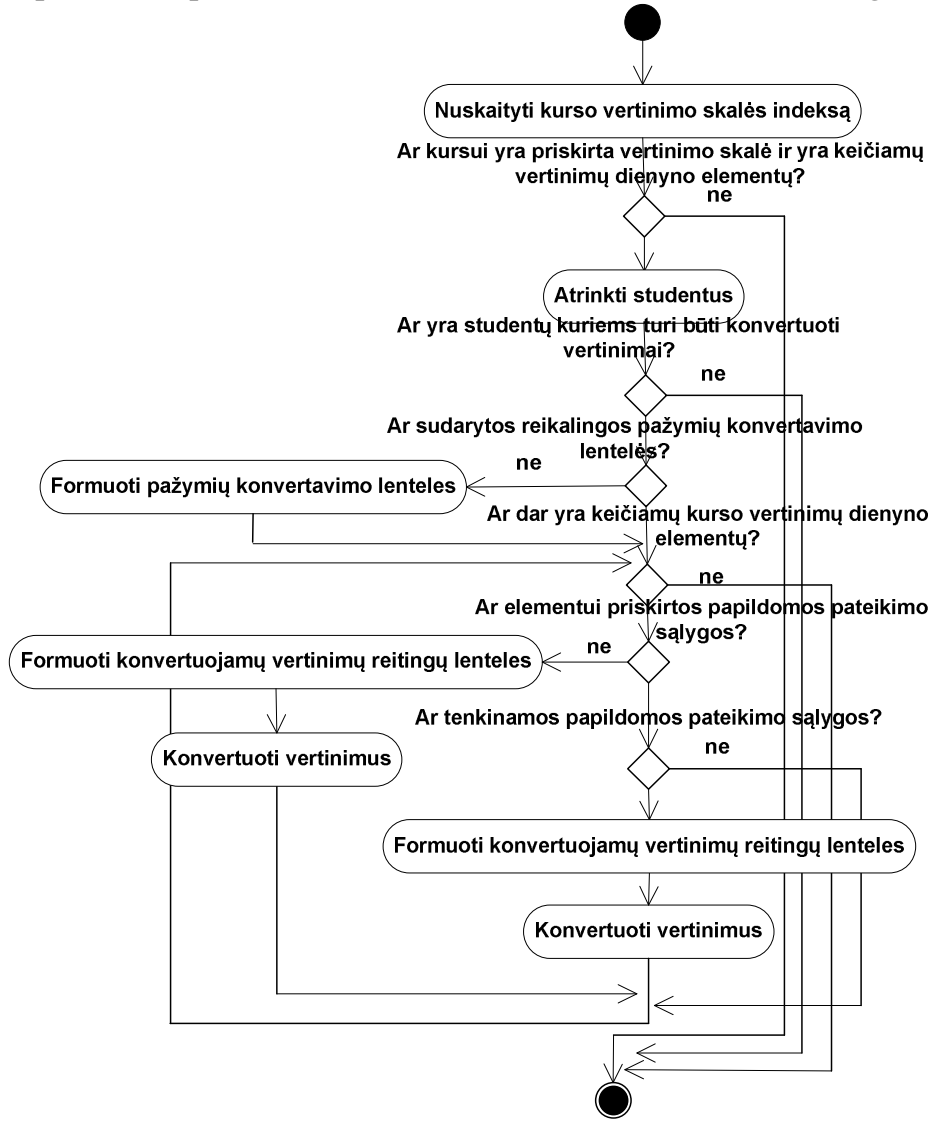

5.11 pav. Vertinimų dienyno pažymių konvertavimo veiklos diagrama Fig. 5.11. Activity diagram of gradebook`s grades transfer 
Vertinimų dienyno ataskaitos modulio stilius aprašomas faile styles.css. Kuriant naują ataskaitų moduli nepažeidžiami ne tik bendri Moodle sistemos programavimo principai, bet ir išlaikomas bendras sistemos stilius. Naujojoje vertinimų dienyno ataskaitoje naudojamas bendras vertinimų dienyno ataskaitų stilius.

\subsection{Pažymių konvertavimo modulio panaudojimas e. mokymosi procese}

Modulinè Moodle sisitemos architektūra užtikrina nesudètingą naujų modulių diegimą. Pažymių konvertavimo algoritmas integruojamas ị Moodle sistemą, išplečiant vertinimų dienyno funkcijas, įdiegiant naują vertinimų dienyno ataskaitų moduli. Moodle sistemos funkcionalumas išplečiamas pažymių konvertavimo funkcija, šio modulio failus perkeliant i Moodle šakniniame kataloge esančio katalogo grade pakatalogi report. Taip pat atnaujinant Moodle bibliotekos failų lib/grade/grade_grade.php, lib/grade/constants.php, lib/gradelib.php turini, pakeičiant kalbos failus /lang/en/grades.php, /lang/en/moodle.php, atnaujinant failus /course/edit form.php, /user/editadvanced_forms.php, papildant Moodle grade katalogo pakatologi edit naujais failais. Modulio diegimas baigiamas administratoriaus meniu Site administration parenkant punktą Notifications ir vykdant diegimo nurodymus, t. y. patvirtinant duomenų bazès struktūros pakeitimus, nustatant reikalingus leidimus.

Pažymių konvertavimo modulio konfigūravimas baigiamas administratoriaus meniu Site administration parenkant punktą Grades/General settings ir pakeičiant vertinimų dienyno nuostatas, t. y. nustatant naują vertinimų dienyno ataskaitą pagrindine naudotojų profilių vertinimų dienyno ataskaita (5.12 pav.).

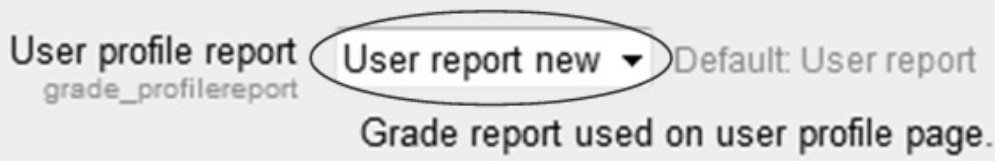

5.12 pav. Pažymių konvertavimo modulio konfigūravimas

Fig. 5.12. Configuration of grades transfer module

Sistemos administratorius, keisdamas naujosios vertinimų dienyno ataskaitos nuostatas, gali paslëpti arba nustatyti konvertuotų pažymių rodymą (5.13 pav.). Naujosios vertinimų dienyno ataskaitos nuostatos nustatomos administratoriaus meniu Site administration, parenkant punktą Grades/Report set- 
tings/user new. Paslèpus konvertuojamų pažymių rodymą, naujoji vertinimų dienyno ataskaita igauna įprastos naudotojų ataskaitos formą.

\section{Show transfer grade $\square$ Default: Yes}

Show the transfer grade value of each grade item'

5.13 pav. Naujosios vertinimų dienyno ataskaitos konfigūravimas

Fig. 5.13. Configuration of new gradebook report

Vertinimų dienynas yra administruojamas ir kurso lygmenyje. Kurso dèstytojas vertinimų dienyne ne tik apibrèžia vertinamas veiklas, nurodo jų apibendrinimo metodus, apibrèžia galutini kurso pažymį, bet ir koordinuoja vertinimu dienyno pateikimą studentams. Keisdamas kurso parametrus, kurso dėstytojas vertinimų dienyną gali paslèpti arba nustatyti jo rodymą (5.14 pav.).

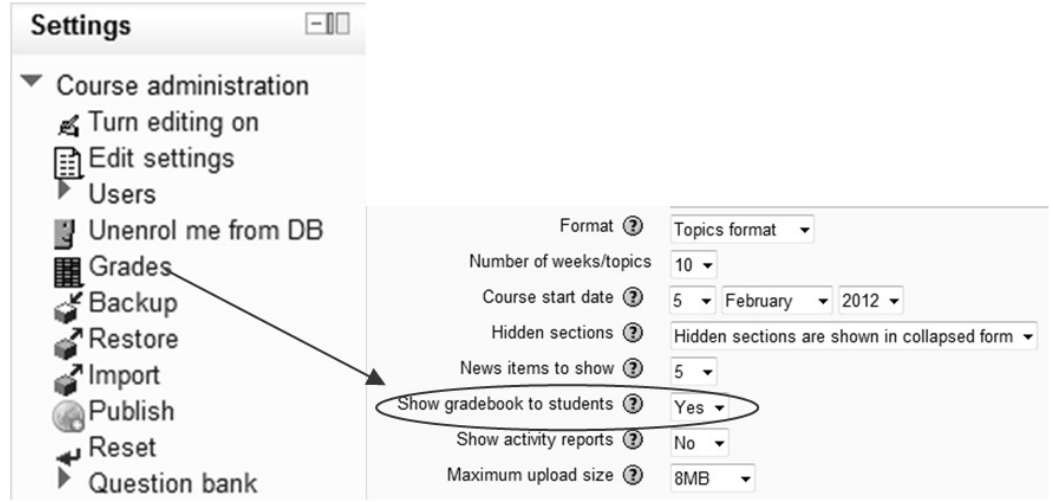

5.14 pav. Kurso dienyno pridèjimas

Fig. 5.14. Addition of course gradebook

Pažymių konvertavimo modulis praplečia Moodle sistemos funkcionalumą. Jis lanksčiai integruojasi ị bendrą Moodle sistemos struktūrą. Vertinimų dienyno papildymas pažymių konvertavimo funkcija aktualus, teikiant jungtinius e. mokymosi kursus ivvairių šalių studentams.

Registruojant įvairių šalių studentus bendroms modulio studijoms, administratorius ịveda informaciją, būtiną korektiškam pažymių konvertavimo modulio funkcionavimui (5.15 pav.). Tam kad pažymių konvertavimo modulis, konvertuotų pažymius iš vienos studijų rezultatų vertinimo skalès į kitą - būtini šias vertinimo skales aprašantys duomenys. Pažymių konvertavimo modulio duomenų bazejje saugomi ne tik vertinimo skalių žymejjimai, bet ir vertinimo skalių pažymių indeksai, šių skalių teigiamų vertinimų skaičius bei teigiamų pažymių pasiskirstymo duomenys. 


\section{Site administration 圆 Notifications

5.15 pav. Vertinimo skalès informacijos ịvedimas

Fig. 5.15. Entering information of grading scale

Tam, kad e. mokymosi kurse būtų vykdomas pažymių konvertavimas, būtina šiam kursui priskirti vertinimo skalę. Priskirta vertinimo skalè nurodo, kokioje vertinimo skalèje vykdomos kurso studijos. Ši e. mokymosi kurso konfigūravimo funkcija yra priskirta sistemos administratoriui arba kurso kūrèjo teises turinčiam naudotojui (5.16 pav.).

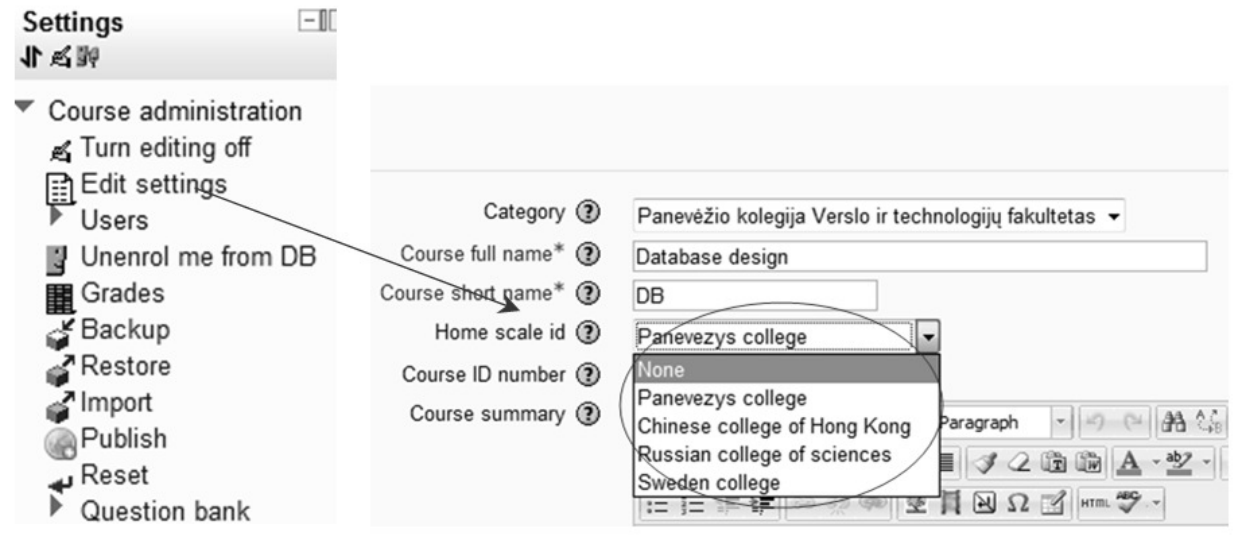

5.16 pav. Kurso parengimas pažymių konvertavimui

Fig. 5.16. Preperation of course for grade transfer 
Studentams, kuriems e. mokymosi kurse konvertuojami pažymiai, priskiriama jų institucijos studijų rezultatų vertinimo skalè. Studentų duomenis gali koreguoti sistemos administratorius, parinkdamas administratoriaus meniu Site administration, punktą Browse list of users (5.17 pav.).

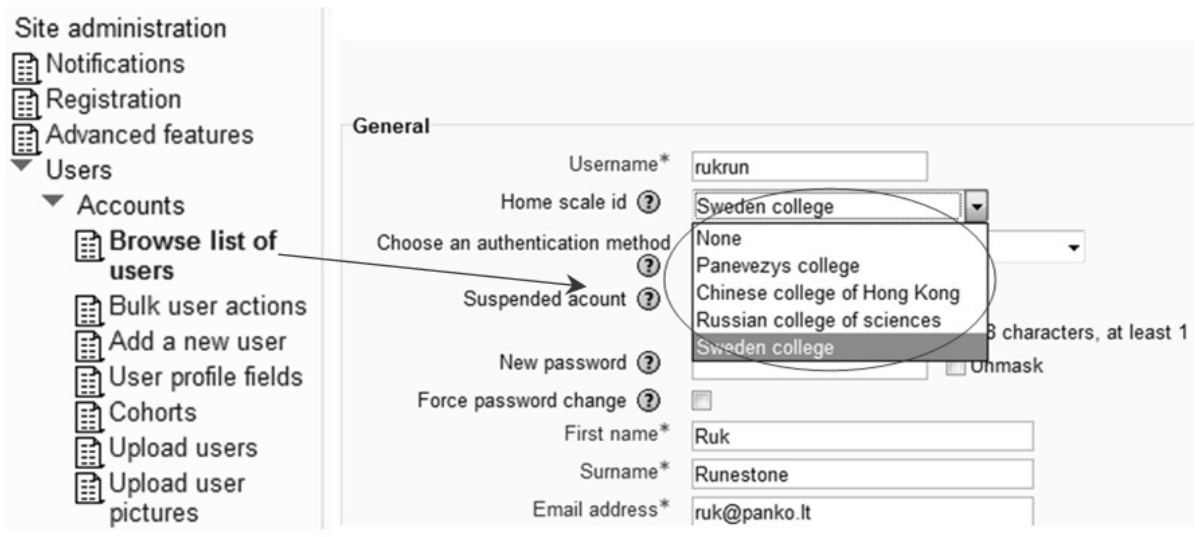

5.17 pav. Vertinimo skalès studentui parinkimas

Fig. 5.17. Selection of grade scale for student

Kurso dèstytojui apibrèžus kurso dienyną bei nustačius galutinio pažymio skaičiavimo formulę, studentas gali stebèti vertinimų pasikeitimus tiek institucijos vykdančios studijas studijų rezultatų vertinimo skalejje, tiek studento institucijos studijų rezultatų vertinimo skalèje. Studentui atvèrus kurso pažymių knygelę, pažymiai pateikiami dviejose vertinimo skalèse. Pažymiai, perskaičiuoti i besimokančiojo studijų rezultatų vertinimo skalę, teikia išsamią grįžtamąją informaciją studentui. Jis gali realiai vertinti pasiektus mokymosi rezultatus.

Žemiau pateiktame paveiksle pavaizduota Kinijos studento, kurio institucijoje taikoma raidinè $A-F$ studijų rezultatų vertinimo skalè, vertinimų dienyno ataskaita (5.18 pav.). Šioje ataskaitoje studentui pateikiami pažymiai ne tik institucijos, vykdančios modulio studijas, vertinimo skalejje, bet ir šio studento institucijos vertinimo skaleje.

Integravus pažymių konvertavimo algoritmą i Moodle sistemą, kurso dèstytojas taip pat gali peržiūrèti ir atsispausdinti konvertuotus studentų vertinimus. Studentai gali peržiūrèti ir atsispausdinti tik savo vertinimus. Kurso dèstytojas gali atsispausdinti pasirinkto studento ar studentu grupès vertinimo dienyno su konvertuotais pažymiais ataskaitą. 
User report new - Bai Juyi

\begin{tabular}{|c|c|c|c|c|}
\hline Grade item & Grade & Range & Percentage & Transfer grade \\
\hline \multicolumn{5}{|l|}{ Database design } \\
\hline \multicolumn{5}{|l|}{ Test } \\
\hline$\nabla$ Relation technology fundamentals. Test. & 7.00 & $0-10$ & $70.00 \%$ & $\mathrm{c}$ \\
\hline$\square$ Database design tool CA ERWIN. Test & 8.00 & $0-10$ & $80.00 \%$ & $B$ \\
\hline$\nabla$ SQL language. Test & 9.33 & $0-10$ & $93.33 \%$ & A \\
\hline $\bar{X}$ Average of test & 8.00 & $0-10$ & $80.00 \%$ & $B$ \\
\hline \multicolumn{5}{|l|}{ Control works } \\
\hline Logical and physical data model & 9.00 & $0-10$ & $90.00 \%$ & A \\
\hline Normalizing data to design tables & 9.00 & $0-10$ & $90.00 \%$ & A \\
\hline SQL language & 9.00 & $0-10$ & $90.00 \%$ & A \\
\hline $\bar{X}$ Average of control works & 9.00 & $0-10$ & $90.00 \%$ & $A$ \\
\hline Independent work & 7.00 & $0-10$ & $70.00 \%$ & $\mathrm{c}$ \\
\hline Exsm & 7.00 & $0-10$ & $70.00 \%$ & c \\
\hline $\bar{X}$ Final grade & 7.70 & $0-10$ & $77.00 \%$ & c \\
\hline
\end{tabular}

5.18 pav. Studento vertinimų dienyno ataskaita

Fig. 5.18. Gradebook report of student

Apibendrinant vertinimų dienyno su pažymių konvertavimo funkcija panaudojimo e. mokymosi procese galimybių apžvalgą, galima teigti, kad naujoji vertinimų dienyno ataskaita yra paprastai administruojama. Kadangi naujoji vertinimų dienyno ataskaita yra parengta naudojant bendrus Moodle ataskaitų kūrimo principus, todèl šiai ataskaitai yra būdingas ịprastas dizainas ir valdymas. Vertinimų dienyno ataskaitą paprasta ir patogu naudoti tiek studentams, tiek dèstytojams. Integruota pažymių konvertavimo funkcija praplečia vertinimo grižtamosios informacijos pateikimo studentams galimybes.

\subsection{Penktojo skyriaus išvados}

1. Ivvertinus dviparametrio ir triparametrio pažymių konvertavimo modelių algoritmų sudètingumą, integruojant šiuos algoritmus ị e. mokymosi sistemas, nustatyta, kad ir triparametrị pažymių konvertavimo modelị realizuojančio algoritmo sudètingumas e. mokymosis sistemose dideja. Dviparametrio ir triparametrio pažymių konvertavimo modelių konvertavimo reitinguojamoje vertinimų aibejje skirtumai gaunami tik ženkliai didejjant konvertuojamos pažymių aibės dydžiui, todèl pažymiams e. mokymosi sistemose konvertuoti parinktas dviprametris vertinimų konvertavimo modelis.

2. Atlikus pažymių konvertavimo modulio funkcionalumo e. mokymosi sistemose analizę nustatyta, kad kuriamas modulis turi būti pritaikytas trijų lygių, skirtingas modulio prieigos teises turintiems naudotojams: administratoriui, dès- 
tytojui ir studentui. Administratoriui priskiriamos pažymių konvertavimo modulio parengimo vertinimams konvertuoti teisès. Studentui suteikiamos pažymių konvertavimo ataskaitos peržiūros ir spausdinimo galimybès. Kurso dèstytojui priskiriamos atskirų studentų ir pasirinktų grupių pažymių konvertavimo ataskaitų peržiūros ir spausdinimo galimybès.

3. Atlikus pažymių konvertavimo algoritmo integravimo ì Moodle sistemą galimybių analizę, nustatyta, kad, ši algoritmą patogiausia integruoti, išplečiant vertinimų dienyno funkcijas, sukuriant naują Moodle sistemos vertinimų dienyno ataskaitų moduli. 


\section{Bendrosios išvados}

1. Atlikus tyrimų e. mokymosi rezultatu vertinimo technologiju srityje analizę, nustatyta, kad šie tyrimai vykdomi duomenų gavybos technologijų naudojimo, e. mokymosi turinio projektavimo, e. mokymosi rezultatu vertinimo sistemu projektavimo, e. mokymosi ir e. mokymosi rezultatų vertinimo sistemų tobulinimo, standartizavimo kryptimis. Vertinant tyrimus e. mokymosi rezultatu vertinimo technologijų internacionalizavimo srityje, nustatyta, kad Lietuvos ir pasaulio mokslininkų darbuose analizuojamas e. mokymosi rezultatų vertinimo technologiju pritaikymas skirtingoms kalbinèms terpèms, tačiau nèra tiriamas šių technologiju pritaikymas skirtingoms studiju rezultatų vertinimo sistemoms.

2. Išnagrinejjus įvairių šalių studijų rezultatų vertinimo sistemas pastebèta, kad studentų pasiekimams vertinti dažniausiai taikomas kriterinis studijų rezultatų vertinimo modelis. Aukštojo mokslo institucijose taikomos vertinimo skalès skiriasi ne tik žymèjimu, dydžiu, teigiamiems ir neigiamiems vertinimams skirtu balų skaičiumi, apibūdinimu, bet ir taikymo praktika.

3. Sukurti dviparametris ir triparametris pažymių konvertavimo modeliai. Dviparametris pažymių konvertavimo modelis įvertina sukauptus teigiamų pažymių pasiskirstymo duomenis konvertuojamose studijų rezultatų vertinimo skalèse ir teigiamus pažymius konvertuoja labiausiai tikètino vertinimo atitikmens principu, ịvertinant vertinimo reitingą analizuojamų pažymių grupeje. Triparametris pažymių konvertavimo modelis papildomai įvertina konvertuojamos pa- 
žymių aibės teigiamų pažymių pasiskirstymą. Triparametriame pažymių konvertavimo modelyje taikomi tokie pat vertinimu konvertavimo principai kaip ir dviparametriame modelyje. Vertinant pažymių konvertavimo algoritmų sudètingumą, nustatyta, kad triparametrio pažymių konvertavimo modelio algoritmas apytiksliai daugiau nei 2 kartus sudètingesnis.

4. Atlikus dviparametrio ir triparametrio pažymių konvertavimo modelių eksperimentini tyrimą, nustatyta, kad vertinimų konvertavimo neatitikimo atvejus sąlygoja teigiamos vertinimo skalių dalies dydžių ir teigiamų pažymių pasiskirstymo skirtumai. Tiksliam ir vienareikšmiam pažymių konvertavimui būtinas vertinimų reitingavimas. Reitinguojamos pažymių aibès konvertavimo skirtumų, taikant dviparametrị ir triparametrị pažymių konvertavimo modelius, skaičius tiesiogiai priklauso nuo konvertuojamos pažymių aibès dydžio.

5. Atlikus pažymių konvertavimo modulio funkcionalumo analizę, ịvertinus dviparametrio ir triparametrio pažymių konvertavimo algoritmo sudėtingumą, nustatyta, kad pažymiams e. mokymosi sistemose konvertuoti tinkamesnis dviparametris pažymių konvertavimo modelis. Todèl integruojant pažymių konvertavimo funkciją $i$ e. mokymosi sistemas, pažymių konvertavimo modulis turi būti formuojamas dviparametrio pažymių konvertavimo modelio algoritmo pagrindu.

6. İvertinus pažymių konvertavimo algoritmo integravimo ị Moodle sistemą galimybes, nustatyta, kad pažymių konvertavimo algoritmą patogiausia integruoti, išplečiant vertinimų dienyno funkcijas, sukuriant naują vertinimų dienyno ataskaitų modulį. 


\section{Literatūra ir šaltiniai}

Aksomaitis, A. 2002. Tikimybių teorija ir statistika. Kaunas, 331.

Al-A'ali, M. 2007. Implementation of an Improved Adaptive Testing Theory. Educational Technology \& Society, 10(4), 80-94. Available from Internet: $<$ http://www.ifets.info/journals/10_4/9.pdf $>$.

Al-Ajlan, A.; Zedan, H. 2008. Why Moodle. In Future Trends of Distributed Computing Systems, 58-64.

Altbach, G. 2002. Internacionalization of Higher Education in the United states of America and Europe, 274.

Al-Smadi, M.; Guetl, Ch.; Helic, D. 2009. Towards a Standardized e-Assessment System: Motivations, Challenges and First Findings. The 4th International Conference on Mobile and Computer Aided Learning, IMCL2009, 1-6.

Al-Smadi, M.; Guetl, Ch. 2010. SOA-based Architecture for a Generic and Flexible Eassessment System. IEEE EDUCON Education Engineering 2010 - The Future of Global Learning Engineering Education, 493-500.

Al-Smadi, M.; Guetl, Ch.; Kannan, R. 2010. Modular Assessment System for Modern Learning Settings: MASS. International Journal of Computer Applications, 1(9), 43-49.

Aukštikalnis N., Baniulis K. 2006. Towars intelligence and flexibility of learning and knowledge testing environments. Journal of Systemics, Cybernetics and Informatics: $4(1), 80-85$. 
Arefin, A. S.; Mahmud, S.; Khan, M. I. 2005. Designing an Web Based Distance Learning System with Adaptive Testing Module. Asian Journal of Information Technology, 4 (12): 116-119.

Ayuga, F.; Garcia, A. I. 2004. The ECTS system in Spain. University Studies of Agricultural Engineering in Europe, 132-135.

Baniulis, K.; Tamulynas, B. 2005. Duomenų struktūros. Kaunas: Technologija, 298.

Bagdonas, E.; Pataišienè, I.; Patašius, M. 2010. Daugiadisciplinis internetinio verslo žaidimo panaudojimas mokymo procesui. E.švietimas: mokslas, studijos ir verslas. Konferencijos pranešimu medžiaga, 70-76.

Bagues, M.; Labiniy M. S; Zinovyeva N. 2008. Differential Grading Standards and University Funding: Evidence from Italy. CESifo Economic Studies, 54(2), 149-176.

Bates, T. 2006. The World of e-Learning Research: an Overview of Current Research. International Conference of the Learning Sciences, Proceedings: 26-34.

Bielskis, A. A.; Ramašauskas, O.; Stabingis, G. 2005. Valdomujų objektų agentų intelektualizavimas. Elektronika ir elektrotechnika, 8(64), 55-59.

Biggs, J. 1999. What the student does: Teaching for enhanced learning. Higher Education Research and Development, 18(1), 57.

Bischoff, A. 2000. The elements of effective online teaching: overcoming the barriers to success. The online teaching guide: A handbook of attitudes, strategies, and techniques for the virtual classroom. Boston: Allyn\&Bacon, 57-72.

Bizonova, Z.; Ranc, D. Interoperability and Reuse Between Systems in eLearning. Proceedings of World Conference on Educational Multimedia, Hypermedia and Telecommunications, 1700-1705.

Barzdaitis, V.; Mickus, A.; Vidžiūnas, A. 2004. Kompiuterinių programavimo ịgūdžių testavimo sistemų konstravimo principai. Informacines technologijos 2004. Konferencijos pranešimų medžiaga, 21-24.

Burbaitè, R.; Turskienè, S.; Kulvietis, G. Duomenų gavybos technologijų taikymas švietime. Informacijos mokslai, 26-40.

Bergstrom, P.; Granberg, C. 2007. Formative and summative assessment in on-line courses. Advanced principles of effective online teaching. Information Science Press: 61-69.

Biggs, J. 2003. Teaching for Quality Learning at University. Maidenhead: Society for Research into Higher Education. Open University Press: 21-29.

Bulajeva T. 2007. Žiniu ir kompetencijų vertinimas: kaip sukurti studentu pasiekimu vertinimo metodika. Vilnius: 88.

Brauklytė, I; Štuikys, V; Tekutov, J. 2009. Analysis of granularity within generative learning objects to support reusability. Management: 14(1), 107-114. 
Castrol, F.; Vellido, A.; Nebot, A.; Mugica, F. 2007. Applying Data Mining Techniques to e-Learning Problems. Evolution of Teaching and Learning Paradigms in Intelligent Environment, 62, 183-221.

Carless, D.; Joughin, G.; Mok, M. M. C. 2006. Learning-oriented assessment: principles and practice. Assessment \& Evaluation in Higher Education, 31 (4), 395-398.

Cole, J.; Foster, H. 2008. Using Moodle. Teaching with Popular Open Source Management System, 268.

Comparetti, A.; Febo, P.; Orlando, S. 2004. The implementation of ECTS in Italian university departments and institutes of agricultural engineering. University Studies of Agricultural Engineering in Europe, 75-80.

Čekanavičius, V.; Murauskas, G. 2001. Statistika I ir jos taikymai, 238.

Čiegis, R. 2007. Duomenų struktūros, algoritmai ir jų analizè. Vilnius. Technika, 157.

Čiužas, R.; Navickaite, J. 2008. Mokinių pažangos ir pasiekimų vertinimo kaita edukacinès paradigmos virsmo sąlygomis. Pedagogika, 91, 53-59.

Dagienè, V.; Grigas, G.; Jevsikova, T. 2010. Programinès ịrangos lokalizavimas. Monografija. Matematikos ir Informatikos institutas, 328.

Dagienè, V.; Grigas, G.; Jevsikova, T. 2009. Enciklopedinis kompiuterijos žodynas. II papildytas leidimas.

Dagienè, V.; Kurilovas, E. 2007. Design of Lithuanian Digital Library of Educational Resources and Services: the Problems of Interoperability. Information technology and control, 36(4), 402-411.

Dagienè, V.; Kurilovas, E. 2008. Informacinès technologijos švietime, 215.

Dagienè, V.; Kurilovas, E. 2010. Web 2.0 Technologies and Applications in the Best Practice Networks and Communities. Informatics in Education, 9(2), 185-197.

Danielienè, R.; Telešius, E. 2011. Testų konstravimo principų ir testuojamojo parametrų itakos kompiuterinio raštingumo testams analizè. $X V$ kompiuterininku konferencijos mokslo darbai, 45-57.

Dahl, A. B. 2005. Comparison of the Danish and the Virginia Secondary teacher Education System: Their values and Emphasis on Mathematics Content Knowledge. The Montana Mathematics Enthusiast, 2(2): 93-106.

Dahlgren, L. O.; Fejes, A.; Dahlgren, M. A.; Trowald, N. 2008. Promoting mobility or prohibiting learning? The ilusion of comparability through a common grading scale. Conference Proceeding: 28-48.

Dahlgren, L.; Fejes, A.; Dahlgren, M. A.; Trowald, N. 2006. Grading systems, features of assessment and students' approaches to learning. Teaching in Higher Education: 14(2), 185-194. 
Davies, W. M.; Davis, H. C. 2005. Designing Assessment Tools in a Service Oriented Architecture. Proceedings of 1st International ELeGI Conference on Advanced Technology for Enhanced Learning, 59-68.

Delgado Calvo-Floresa, M.; Fajardo Contrerasa, W.; Gibaja Galindob, E.L.; Pe'rezPe'reza, R. 2006. Predicting students' marks from Moodle logs using neural network models". Current developments in Technology-Assisted Education, 586-590.

Devedžic V., Jovanovic J., Gaševic D. 2007. The Pragmatics of Current e-Learning Standards. IEEE Internet Computing, Special Issue on Distance Learning, 11(2), 16-24.

Douzals J. P. 2004. ECTS implementation in agricultural engineering courses in France. University Studies of Agricultural Engineering in Europe, 48-52. Available from Internet: < http://www.aua.gr/tmhmata/beltiosi/panagak/usaeeshop3-procs.pdf\#page=132>.

Dube, T.; Ma, M. 2010. A Flexible E-Assessment System Inspired by Design Methodology Management to Accomodate Diverse Learning Styles. International Journal of Digital Society, 1(1), 44-52.

Dzemydienė, D.; Tankelevičienė, L. 2008. Conceptual Linking of Educational Resources Based on Reasoning over Domain Ontology. Baltic Conf. on Databases and Information Systems, Baltic DB\&IS 2008, 241-252.

Dzemydienè, D.; Tankelevičienè, L. 2008. On the development of domain ontology for distance learning course. The 20th International Conf. EURO mini conference "Continuous optimization and knowledge-based technologies" EurOPT'2008: selected papers, 474-479.

Dzemydiene, D.; Tankeleviciene, L. 2009. Multi-layered knowledge-based architecture of the adaptable distance learning system. Technological and Economic Development of Economy, 15(2), 229-244.

Dzikienè, J. 2010. Adaptyvaus agento aplinkos ir tikslo modelių indukcija deterministineje aplinkoje. Daktaro disertacija. Matematikos ir informatikos institutas, Vytauto Didžiojo universitetas, 116.

Ermalai, I., Vasiu, R. 2009. Study Cases on Specific LMSs Used in Romania and Worldwide. Proceedings of the 13th WSEAS International Conference on COMMUNICATIONS, 111-116.

Falla, J. 2002. Content management: Coping with the Content Chalange: Definitions. Learning content management systems, 7-8.

Finocchietti C., Cappucci, S. 2004. Italy: Accreditation in Progress. Autonomy, Minimum Standards, Quality Assurance. Accreditation and Evaluation in the European Higher Education Area, 123-137.

Foster, D. 2004. Azijos šalių etiketas. Algarvè, 397.

Gaber, S. 2008. Strategies of Educational Reform in the Countries of South Eastern Europe. Proceedings of International Conference on Education, 35-43.

Gage, N.L.; Berliner, D. C. 1994. Pedagoginè psichologija. Vilnius: Alma litera, 387. 
Gouli, E.; Kornilakis, H.; Papanikolaou, K.; Grigoriadou, M. 2001. Adaptive Assessment Improving Interaction in an Educational Hypermedia System.

Gerhard, J.; Mayr, P. 2002. Competing in the E-learning Environment - Strategies for Universities. Proceedings of the 35th Annual Hawaii International Conference on System Sciences (HICSS'02), 115-148.

Gomez, G. R.; Saiz, I.; Dodero, J.M. 2010. Developing the e-Learning-oriented eAssessment. Research, Reflections and Innovations in Integrating ICT in Education, 515-519.

Grigoriadou, M.; Papanikolaou, K.; Kornilakis, H.; G. Magoulas. 2002. ISPIRE: An Inttelligent System for Personalized Instruction in a Remote Environment. Available from Internet: < http://wwwis.win.tue.nl/ah2001/papers/papanikolaou.pdf $>$.

Hanson, M.; Engstrom, E. 2006. The implementation of ECTS grading scale: The KTH perspectives. ECTS and assessment in higher education. Conference Proceedings, 5969.

Hatzigaidas, A.; Papastergiou, A.; Tryfon, G.; Maritsa, D., Galanidis, P. 2003. Adaptive student test evaluation incorporating probabilities. Proceedings of the International Conference on Theory of Mathematics and Informatics - ICTAMI 2003, 35-43.

Haug, G. 1997. Capturing the Message Conveyed by Grades. Interpreting Foreign Grades. World Education News \& Reviews, 10(2): 25-31.

Hillesheim, G. 1998. Distance learning: Barriers and strategies for students and faculty. Internet and Higher Education, 1(1), 31-44.

Hopkins, D. J. 1990. The Educational System of Finland. Background, Structure, Equivalencies, and New Directions. World Education News \& Reviews: 10-18.

Hohner, M.; Tsigaris, P. 2010. Alignment of Two Grading Systems: A Case Study. American Journal of Business Education, 3(7), 93-102.

Imai S. 2008. Development of Japanese - computerized adaptive test. The 23rd International Technical Conference on Circuits/Systems, Computers and Communications (ITC-CSCC 2008), 821-824. Available from Internet: <http://www.ieice.org /explorer/ITC-CSCC2008/pdf/p821_D6-5.pdf >.

Irlbeck, S.; Mowat, J. 2007. Learning Content management system (LCMS). Learning Objects: Standarts, Metadata, Repositories and LCMS, 157-185.

Jurubescu, T. 2008. Learning content Management Systems. Informatica, 4(48), 91-94.

Juškevičienè, A. 2010. Antros kartos saitynas ir švietimas. Lietuvos matematikos rinkinys. LMD darbai, 51, 1-14.

Jamornmann, U. 2004. Techniques for Assessing Students' eLearning Achievement. International Journal of The Computer, the Internet and Management: 12(2), 56-62. Jovaiša, L. 2007. Enciklopedinis edukologijos žodynas. Vilnius: Gimtasis žodis, 135.

Jevsikova, T. 2009. Programinès ịrangos lokalizavimas. Daktaro disertacija. Matematikos ir informatikos institutas, Vytauto Didžiojo universitetas, 149. 
Kang, O. 2004. Higher Education Reform in China Today. Policy Futures in Education, 2(1), 141-149.

Karran, T. 2005. Pan-European grading scales: lessons from national systems and the ECTS. The Bologna process: retrospect and prospects. Higher Education in Europe: 30, $5-22$.

Karran, T. 2004. Achieving Bologna convergence: is ECTS failing to make the grade? Higher Education in Europe, 29(3). Available from Internet: $<$ http://eprints.lincoln.ac.uk/1600/1/ProofHEEArticle1 forRepository.pdf $>$.

Karseth, B. 2005. Curriculum Restructuring in Higher Education: A New Pedagogic Regime in The Third Conference on Knowledge and Politics at the University of Bergen, Proceedings: 15-26.

Kerevičienè, J.; Satkauskaitè, D. 2011. SANTALKA: Filologija, edukologija, 19(1), $38-47$.

Khaskheli, A. R. 2004. Intelligent Agents and e-Learning. Brief Studies in Computer Science, 28-45.

Khribi, M. K.; Jemni, M.; Nasraoui, O. 2009. Automatic Recommendations for ELearning Personalization Based on Web. Educational Technology \& Society, 12 (4), 3042. Available from Internet: <http://www.ifets.info/journals/12_4/4.pdf $>$.

Kovatcheva, E.; Nikolov, R. 2009. An adaptive feedback approach for e-learning systems. IEEE Multidisciplinary Engineering Education Magazine, 4(1/2), 55-57.

Kubiliūnas, R. 2009. Lanksčiai pritaikomų mokymosi objektų formavimo metodas ir jo tyrimas. Daktaro disertacija, 153.

Kubiliūnas, R.; Bareiša, E. 2009. A Formation Method of Flexible Learning Objects. Informatics in Education: 8(1), 49-68.

Kulvietis, G.; Mamčenko, J.; Šileikienė I. 2006. Data Mining Application for Distance education. Information System. WSEAS Transactions on Information Science and Applications, 8(3), 1482-1488.

Kurilovas, E. 2008. Digital Library of Educational Resources and Services Components Interoperability problems. Doctoral Dissertation, 194.

Kurilovas, E. 2007. Digital Library of Educational Resources and Services: Evaluation of Components. Informacijos mokslai: 42(43), 69-77.

Kurilovas, E.; Dagiene, V. 2010. Multiple Criteria Evaluation of Quality and Optimisation of e-Learning System Components. Electronic Journal of e-Learning, 8(2), $141-151$.

Kyriazis, A.; Asderaki, F. 2008. Higher Education in Greece, 185.

Laužackas, R. 2005. Profesinio rengimo terminų aiškinamasis žodynas. Kaunas: Vytauto Didžiojo Universitetas, 105. 
Laužackas, R.; Teresevičienė, M.; Volungevičienè, A. 2009. Nuotolinio mokymo(si) turinio projektavimo modelis: kokybès vertinimo dimensijos ir veiksniai. Acta Paedagogica Vilnensia: 9-29. Available from Internet: <http://www.leidykla.vu.lt /fileadmin/Acta_Paedagogica_Vilnensia/23/9-20.pdf $>$

Laužackas, R., Stasiūnaitienè, E., Teresevičienė, M. 2005. Kompetencijų vertinimas neformaliajame ir savaiminiame mokymesi. Monografija. Kaunas: VDU, 131.

Lukauskas, V.; Bielskis, A.A. 2005. Adaptyvios elektroninio mokymosi aplinkos intelektualiojo komponento kūrimas. Informacijos mokslai, 34, 67-72.

Liu, F. J.; Shih, B. J. 2007. Learning Activitybased E-learning Material Recommendation System. Ninth IEEE International Symposium on Multimedia, 343-348.

Mačerauskas, E.; Kulvietienè, R.; Kozič, A. 2010. Nuotoliniu būdu valdoma reali elektronikos laboratorija. E.švietimas: mokslas, studijos ir verslas. Konferenciju pranešimu medžiaga, 140-149.

Mačiulskis, R.; Turskienė, S. 2011. Struktūrizuotos mokomosios medžiagos pateikimo virtualioje mokymosi aplinkoje Sakai galimybių analizè. XV kompiuterininku konferencijos mokslo darbai, 108-118.

Mačiulskis, R.; Turskienè, S. 2010. Nuotolinio mokymosi aplinkų SAKAI ir MOODLE galimybiu lyginamoji analizè. Informaciniu technologiju taikymas švietimo sistemoje 2010: e-studiju patirtis, aktualijos ir perspektyvos, 62-66.

Maher, A. 2004. Learning Outcomes in Higher Education: Implications for Curriculum Design and Student Learning. Journal of Hospitality, Leisure, Sport and Tourism Education: 3(2), Oxford: Oxford Brookes University, 46-54.

Malan, T. 2004. Implementing the Bologna process in France. European Journal of Education, 39(3), 17-30.

Mamčenko, J.; Tumasonienė I. 2009. Intelligent Data Analysis of E-Learning System Based on data Warehouse, OLAP and Data Mining Technologies. Vadyba, 1(14), $115-120$.

Mamčenko, J.; Šileikienė I. 2006. Duomenų saugyklų ir agentinių technologijų panaudojimas nuotolinio mokymo sistemos duomenims paruošti duomenu gavybai. Proceedings of the 5th WSEAS International Conference on Education and Educational Technology, $171-175$.

Mamčenko, J.; Šileikienė I.; Lieponienė, J.; Kulvietienė, R. 2011. Analysis of electronic exam data using data mining techniques. 17 th International Conference on Information and Software Technologies IT 2011 Conference Proceedings, 215-219.

Mandal, S. 2011. Problem Based Learning Tool as a Plug-in for Moodle. A Thesis. Department of Computer Science and Engineering Indian Institute of Technology, Bombay, Mumbai, 89.

Maciulevičius, S.; Lygutas, T. 2007. ECDL testavimo sistemos naudojimo patirtis ir tobulinimo galimybès. Informacijos mokslai, 42(43), 103-107. 
Mačiulskis, R.; Turskienè, S. 2010. Nuotolinio mokymosi aplinkų Sakai ir Moodle galimybių lyginamoji analizè. Informaciniu technologijų taikymas švietimo sistemoje 2010, 62-66.

McMahont, T.; Thakore, H. 2006. Achieving constructive alignment: putting outcomes first. The Quality of Higher Education, 29-36.

McMahon, T.; O'Riordan, D. 2006. Introducing Constructive Alignment into a Curriculum: Some Preliminary Results from a Pilot Study. The Journal of Higher Education and Lifelong Learning: Oxford University Press, 45-61.

Merceron, A.; Yacef, K. 2005. Educational Data Mining: a Case Study. Proceedings of the 12th International Conference on Artificial Intelligence in Education AIED, 20-26.

Mihhailova, G. 2006. E-learning as internationalization strategy in higher education. Lecturer's and student's perspective. Baltic Journal of Management, 1(3), 270-284.

Namdeo, V.; Singh, A.; Singh, D., Jain, R. C. 2010. Result Analysis Using Classification Techniques. International Journal of Computer Applications (0975 - 8887), 1(22), 151-159.

Nedeva, V. 2005. The possibilities of e-learning, based on Moodle software platform. Trakia Journal of Sciences, 3(7), 12-19.

Nichani, M. LCMS=LMS+CMS[RLOs] - How does this affect the learner? The instructional designer? Learning content management systems, 9-10. Available from Internet: $<$ http://www.elearningpost.com/articles/archives/lcms_lms_cms_rlos/>.

Nicol, D.; Macfarlane-Dick, D. 2006. Formative assessment and self-regulated learning: A model and seven principles of good feedback practice. Studies in Higher Education: 31(2), 199-218. Available from Internet: <http://www.reap.ac.uk /public/Papers/DN_SHE_Final.pdf $>$.

Nunes, S.; Ribeiro, L.; David, G. 2005. Supporting the Bologna Process in HE Information Systems. EUNIS'2005 European University Information Systems, Manchester: 2733. Available from Internet: <http://www.ngc.niro.nnov.ru/2_2005/7. pdf >.

Parisk, A.; Simos, R.; Manolis, S. 2004. An Architecture for Open Learning Management Systems.

Patašienė, I. 2008. İmonès ekonominių veiksnių imitacinis modeliavimas ir taikymas mokymo procesui. Daktaro disertacija, 144.

Petty, G. 2006. Šiuolaikinis mokymas. Vilnius: Tyto Alba, 105.

Petrauskienè, R. 2011. Informacinių technologijų taikymo nuotolinio mokymosi kokybei gerinti metodai ir priemonès. Daktaro disertacija. Kaunas: Technologija, 151.

Petrovskaja, T. S.; Chuchalin, A. I.; Boev, V. O. 2006. The Bologna Process and Russian Engineering Education. Conference Proceedings: 108-111.

Petrov, M.; Petrova, A. A. 2009. Three View Model of e-Portfolio Assessment System. Problems of Engineering Cybernetics and Robotics, 92-98. 
Piccoli, G.; Ahmad, R.; Ives, B. 2001. Web-based virtual learning environemnts: A research framework and a preliminary assessment of effectiveness in basic it skills training. MIS Quarterly: 24(3), 75-81. Available from Internet: $<$ http://www.accessmylibrary.com/coms2/summary_0286-27255428_ITM>.

Preidys, S; Sakalauskas, L. 2010. Nuotolinių studijų kokybės gerinimas, taikant duomenų gavybos metodais paremtą studentų veiklos stebėsenos sistemą. E.švietimas: Mokslas, Studijos ir Verslas, 149-154.

Qwaider, W. O; Hattab, E. 2010. Learning Content Management System (LCMS) Versus Learning Management System (LMS). Excellent In Education 2010, Research Strategic Planning - Development, 1-9.

Rajeckas, V. 1999. Mokymo organizavimas. Kaunas: Šviesa, 382.

Rauhvargers, A. 2011. Latvia in Bologna process. Report on reforms in Latvia's higher education on the way towards European Higher Education Area, 19-35.

Rosenstone S. J. 2004. Challenges Facing higher education in America: Lessons and Opportunities. Taking Public Universities Seriously, 10-19. Available from Internet: < http://www.utoronto.ca/president/04conference/downloads/Rosenstone.pdf $>$.

Rutkauskienė, D; Mušankovienė, R. V.; Krivickienė, V. 2010. LieDM tinklo nariams teikiamų paslaugų poreikia. E.švietimas: Mokslas, Studijos ir Verslas, 149-154.

Sadler, R. 1998. Formative assessment and the design of instructional systems. Instructional Science, 119-144.

Sarre, S.; Foulonneau, M. 2010. Reusability in e-assessment. International Conference on Internet and Web Applications and Services Conference Proceedings, 420 - 424.

Sekliuckis, V.; Gudas, S.; Garšva, G. 2004. Informacijos sistemos ir duomenų bazès, 235.

Slotkienè, A. 2009. Aktyvaus mokymosi objekto projektavimo metodas ir jo tyrimas. Daktaro disertacija, 136.

Slotkienè, A.; Baniulis, K.; Paulikas, G. 2009. Desining reusable active learning object by using its information modelį. Jaunujų mokslininku darbai: 3(24), 2009, 107-113.

Šalna, R. 2007. Ko galètume pasimokyti iš Japonijos švietimo sistemos? Veidas, 40, 4-5.

Šileikienè, I. 2005. E. Mokymosi informacinių technologijų tyrimas. Daktaro disertacija, 127.

Taylor, R. M. 2009. Defining, constructing and assessing learning outcomes. Rev. sci. tech. Off. int. Epiz.: 28 (2), 779-788.

Targamadzè, A.; Balbieris, G.; Kubiliūnas, R. 2005. The new generation of virtual learning environments in Lithuania. Information technology and control, 34(3). Available from Internet: <http://itc.ktu.lt/itc343/Balbier343.pdf >. 
Targamadzè, A.; Petrauskienè, R. 2008. Nuotolinių studijų kokybė technologijų kaitos sąlygomis. Aukštojo mokslo kokybè: 5, 15-31.

Targamadzè, A.; Petrauskienè, R. 2010. Impact of information technologies on modern learning. Information Technology and Control, 39, 169-175.

Targamadzè, A.; Petrauskienè, R. 2011. The use of information technology tools for improving the quality of learning. 17 th International Conference on Information and Software Technologies. IT 2011 Conference Proceedings, 209-214.

Telešius, E.; Danielienè, R. 2009. Internetinès ECDL testavimo sistemos inovatyvūs sprendimai. Informacijos mokslai, 50, 257-261.

Teresevičienė, M.; Gedvilienė, G. 2000. Mokymasis bendradarbiaujant. Vilnius: Garnelis, 135 .

Teresevičienè, M.; Oldroyd, D.; Gedvilienė, G. 2004. Suaugusiųjų mokymasis: andragogikos didaktikos pagrindai. Kaunas: VDU, 189.

Uden, L. 2004. Editorial. International journal of Learning Technology, 1(1), 1-15.

Vincent, L.; Gumara, X. 2009. Data Mining for Instructional Design, Learning and Assessment. E-learning, experiences and future, 147-162.

Wagenaar, R. 2008. Learning Outcomes a Fair Way to Measure Performance in Higher Education: the TUNING Approach. Outcomes of higher education: Quality relevance and impact: 51-59. Available from Internet: <http://www.oecd.org /dataoecd/60/7/41203784.pdf>

Wang, W.; Weng, J.; Su, J.; Tseng, S. 2006. Learning Portfolio Analysis and Mining for SCORM Compliant Environment. Educational Technology \& Society 9(1), 262-275.

Warfvinge, P. 2008. A generic method for distribution and transfer of ECTS and other norm-referenced grades within student cohorts. European Journal of Engineering Education: $33(4), 453-462$.

Yorke, M.; Barnett, G.; Bridges, P.; Evanson, P.; Haines, C.; Jenkins, D.; Knight, P.; Scurry, D.; Stowell, M.; Woolf, H. 2002. Does Grading Method Influence Honours Degree Classification? Assessment and Evaluation in Higher Education, 27(3), 269-279.

Zedan, M. H.; Hassan, H. A.; El-Beltagy, S. R.; Rafea, A. A. 2011. A Model for Aligning Assessment Items. Information and Knowledge Engineering, 2(1), 17-23.

Žemaitis, S. 2009. Elektroninio portfelio realizacija Moodle sistemoje. Informacijos mokslai, 130-135.

Абакирова, Г. Б. 2010. Инновации в организации образовательного процесса. Состояние и перспективы развития высшего образования в Казахстане - Влияние программы Темпус: 10-14. Available from Internet: <http://www.tempuskaz.kz /files/ts.pdf $>$.

Аскеров, Ш. Г. 2009. Новые критерий оценки знаний. 2009. Международный журнал образования, 6, 7-11. 
Богомолов, В. А. 2007. Обзор бесплатных систем управления обучением. Educational Technology \& Society: 10(3), 46-71. Available from Internet: $<$ http://ifets.ieee.org/russian/depository/v10_i3/pdf/9_bogomolov.pdf $>$.

Борисова, Г.; Куусела, Т. 2009. Обзор тенденций в сфере образования республики Беларусь. Available from Internet: <http://213.215.218.75/pubmgmt.nsf/ DC9BFC15C8B74B65C125776900533BB2/\$File/NOTE87MKS5.pdf>.

Ваганов, Д. В.; Редьков, Е. В. 2007. Разработка регламента массового тестирования студентов в системе MOODLE. Available from Internet: <http://www.infoco.ru /file.php/3/itno-2007/moodle/9.doc $>$.

Гусев, П. Современные системы управления обучением в западных и российских компаниях. 2004. Available from Internet: <http://www.fors.ru/pls/portal/docs /PAGE/FDC_RU/NEWS/NEWS_MATERIALS/PERSONAL_GUSEV_2004.PDF>

Дианова, В. М. 2008. О внедрении новых методик оценивания знаний студентов. Развитие научно-образовательного сотрудничества вузов России и США в области гуманитарных наук. Сборник материалов Международного научнопрактического семинара: Ростов н/Д: Изд-во ЮФУ, 78-93.

Зайцева E., Bell F. 2005. Строительство виртуальной образовательной сети: почему мы выбрали Open Source. Technology \& Society: 8(4), 32-40. Available from Internet: $<$ http://ifets.ieee.org/russian/depository/v8_i4/pdf/1.pdf $>$.

Кухникова, Т.К. 2009. Оценивание результатов обучения в процессе изучения истории Украиныв техническом вузе. Теоретические основы современной педагогики и образования, Севастополь: Видво СевНТУ, 32-35. Available from Internet: <http:/www.nbuv.gov.ua/portal/natural/Vsntu/2008_2009/96-SevNTU/9606.pdf $>$.

Мутанов, Г. М.; Антонов, В. А.; Швец, О. Я. 2010. Международное признание профессиональных квалификаций системы образования республики казахстан и проблемы присоединения её к Болонскому процессу. Состояние и перспективы развития высшего образования в Казахстане - Влияние программы Темпус: Алматы, 2010, 10-14. Available from Internet: <http://www.tempuskaz.kz /files/ts.pdf $>$.

Радаев, В. В. 2006. Новые формы организации учебного процесса (анализ опыта ГУ - ВШЭ). М.: Изд. дом ГУ ВШЭ, 61.

Репида, В.Б. 2009. Система высшего образования в начале XXI века: опыт Республики Молдова. ВЕСТНИК РГТЭУ: 6(33), 18-29. Available from Internet: $<$ http://www.rsute.ru/structure/administration/Unad/Vestnik/DocLib4/2009\%20год/Вес тник\%20РГТЭУ\%20№6(33).pdf\#page=18>.

Смирнова, Е.; Алпатова, Т. Классификация систем дистанционного обучения. Available from Internet: http://www.redcenter.ru/?sid=312.

Шаталова, Т.С.; Меженская, В.В.; Савченко, С.О. Обеспечение качества учебного процесса посредством балльно-рейтинговой системы оценивания знаний. 306-314 



\section{Teisès aktai ir dokumentai}

Aalto university. Grading system. Available from Internet: <http://www.aalto.fi /en/studies/student_life/methods/>.

Academic Information centre. Grading system in Latvia. Available from Internet: $<$ http://www.aic.lv/portal/en/grading_system.html $>$.

Bilkent university, Turkey. Grading System. Available from Internet: $<$ http://www.bilkent.edu.tr/bilkent/academic/exchange/grading.html $>$.

Bologna declaration. Joint declaration of the European ministres of Education. Bologna, June 19, 1999. Available from Internet: <http://www.bolognaberlin2003.de/pdf/bologna_declaration.pdf $>$.

Bologna Process at the University of Helsinki. University of Helsinki, 2004. Available from Internet: <http://www.helsinki.fi/tutkinnonuudistus/materiaalit /raportit/Bologna_review_20041122.pdf>.

Bulgarian-American Commission for Educational Exchange, Bulgaria. Main Grading System Used by Education Institutions in Bulgaria. Available from Internet: $<$ http://www.fulbright.bg/en/p-Educational-System-of-Bulgaria-18/>.

Centre of Republic of Slovenia for Mobility and European Educational and Training Programmes. Study in Slovenia. Available from Internet: $<$ http://www.cmepius.si/en/welcome_to_slovenia/study_in_slovenia/organisation.aspx $>$. 
Curricula with new syllabuses and knowledge requirements and a new grading scale. Fact sheet. Ministry of Education and Research, Sweden. 2008. Available from Internet: $<$ http://www.sweden.gov.se/content/1/c6/11/77/01/1011cd7a.pdf $>$.

Danish Agency for International Education. Grading systems in Denmark. Available from Internet: <http://en.iu.dk/education-in-denmark/detailed-information/gradingsystems $>$.

Dopunska isprava o studiju. Upute, pravila i ogledni primjeri. Republika Hrvatska Ministarstvo znanosti, obrazovanja i športa. Zagreb, 2008. Available from Internet: $<$ http://www.pravst.hr/dokumenti/dokpdf_upute_za_ispunjavanje_dopunske_isprave_o_ studiju_v3_2.2.pdf>.

ECTS User Guide. European Communities, 2009. Available from Internet: $<\mathrm{http}$ ://ec.europa.eu/education/lifelong-learning-policy/doc/ects/guide_en.pdf $>$.

Europos švietimo informacijos tinklas. Estijos studijų rezultatų vertinimo sistema. Available from Internet: $<$ http://archimedes.ee/enic/File/Grading\%20system.PDF>.

Grading systems at Lund University, Sweden. Available from Internet: $<$ http://www5.lu.se/upload/RULESandREGULATIONS/GradingsystemsExamensordnin gbilaga2.pdf $>$.

HAAGA-HELIA university of Applied Sciences. International Student Handbook 2010-2011. Available from Internet: <http://www.haaga-helia.fi/en/about-haagahelia/int/exch/HH_International_Student_Guide_2010-11.pdf $>$.

Helsinki Metropolia University of Applied Sciences. Evaluation and Certificates. Available from Internet: <http://www.metropolia.fi/en/degree-programmes/openstudies/evluates-and-certificates/>.

International Qualifications Assessment Service. 2007. International Education Guide. For the assessment of education from the United Kingdom of Great Britain and Northern Ireland, 79. Available from Internet: <http://www.employment.alberta.ca /documents/WIA/WIA-IM_iqas_uk_profile.pdf>.

Karlstad university, Sweden. Grading system. Available from Internet: $<$ http://www.kau.se/en/education/academic-system/grading-system>.

Lietuvos aukštojo mokslo tarptautiškumo skatinimo 2011-2012 metu programa, 2011.

Lietuvos Respublikos švietimo ir mokslo ministras ịsakymas dèl studijų rezultatų vertinimo sistemos patvirtinimo. Available from Internet: $<$ http://www.smm.lt/smt/docs/priemimas/Isak_Vert_skale.pdf $>$

Lietuvos Respublikos švietimo ir mokslo ministro sudarytos darbo grupès parengtos rekomendacijos studiju rezultatu vertinimams tobulinti. Available from Internet: $<\mathrm{http}: / / \mathrm{www} . \mathrm{smm} . \mathrm{lt} / \mathrm{msr} / \mathrm{docs} /$ Rekomend_09_02_09.doc $>$.

Ministry of Education and Research, Denmark. Order on the Marking Scale and Other Forms of Assessment, 2005. Available from Internet: < http://www.ubst.dk/en /Ministerial\%20Order\%20on\%20the\%20Grading\%20Scale\%20and\%20Other\%20Forms $\% 20$ of.pdf $>$. 
Ministry of Education and Research, Denmark. Ministerial Order on the Grading Scale and Other Forms of Assessment of University Education (grading scale order), 2007. Available from Internet: <http://eng.uvm.dk/Uddannelse/General/ Marking\%20Scale.aspx>.

Ministry of Education and Research, Denmark. 7-point grading scale. Available from Internet: http://eng.uvm.dk/Uddannelse/General/Marking\%20Scale.aspx.

Ministry of Education and Research, Iceland. Organisation of the education system in Iceland. Available from Internet: <http://eng.menntamalaraduneyti.is/media/MRN-PDFAlthjodlegt/IC_EN_Tertiary-Education.pdf $>$.

Ministry of Education and Research, Latvia. The education system in Latvia. Available from Internet: <http://izm.izm.gov.lv/education/education-system.html>.

Ministry of Education and Research, Norway. Degree structure and grading system. Available from Internet: <http://www.regjeringen.no/en/dep/kd/Selected-topics/HigherEducation/Degree-structure-and-grading-system.html?id=491287>.

Ministry of Education and Research, Spain. Credit and Grading Systems, 2011. Available from Internet: < http://www.fi.upm.es/docs/servicios/tramites/431_UPMGrading\%20System.pdf $>$.

Ministry of Education and Research, Sweden. Summary of the Government Bill A new grading scale. Available from Internet: <http://www.regeringen.se/sb/d/10281/a/97862>.

Ministry of Education and Research, Sweden. A new grading scale. Available from Internet: <http://www.regeringen.se/content/1/c6/09/78/62/a72a0612.pdf $>$.

Ministry of Education of the Republic of Serbia. Higher Education. Available from Internet: <http://www.mp.gov.rs/page.php?page=78>.

Ministry of Education, Culture, Sports, Science and Technology. 2004. The Development of Education in Japan. Available from Internet: < http://www.ibe.unesco.org/International/ICE47/English/Natreps/reports/japan.pdf>.

Naval science and engineering institute, Turkey. Erasmus information package. Available from Internet: <http://www.dho.edu.tr/Erasmus/Erasmus_Info_Package_ March2010.pdf $>$.

Netherlands organization for international cooperation in higher education. Evaluation of foreign degrees and qualifications in the Netherlands. Country module - Finland, 2011.

Organisation of the education system in Norway 2009/2010. European Commission. Available from Internet: <http://eacea.ec.europa.eu/education/eurydice/documents /eurybase/eurybase_full_reports/NO_EN.pdf $>$.

Points, Grades And Examinations at Uppsala University, Sweden. Available from Internet: <http://www5.lu.se/rules-and-regulations/untitled/rules-and-regulations/studentsand-education/degrees-and-grading-system $>$. 
Structures of Education and Training Systems in Europe. Denmark. European Commission, 2010. Available from Internet: <http://eacea.ec.europa.eu/ education/eurydice/documents/eurybase/structures/041_DK_EN.pdf>.

Structures of Education and Training Systems in Europe. Bulgaria. European Commission, 2007. Available from Internet: <http://eacea.ec.europa.eu/education/eurydice /documents/eurybase/eurybase_full_reports/BG_EN.pdf>.

The Bologna Process 2020 - The European Higher Education Area in the new decade. Available from Internet: <http://www.smm.lt/t_bendradarbiavimas/docs/bp/ Leuven_Louvain-la-Neuve_Communique_April_2009.pdf $>$.

Tuning Europos švietimo struktūrų suderinimas. Universitetų indèlis ị Bolonijos procesą. Švietimo mainų paramos fondas, 2007. Available from Internet: $<\mathrm{http} / /$ tuning.unideusto.org/tuningeu/images/stories/template/Lithuanian_version.pdf $>$.

University of Belgrade - Practical Guide, Serbia, 2010. Available from Internet: $<$ http://www.bg.ac.rs/eng/IRO/pdf/Belgrade-PracticalGuide2010.pdf $>$.

University of Eastern Finland. Credits and grades. Available from Internet: $<$ http://www.uef.fi/studies/credits-and-grades $>$.

University of Helsinki. Reformed grading system. Available from Internet: $<$ http://www.helsinki.fi/studying/grading.shtml $>$.

University of Sarajevo, Bosnia \& Herzegovina. Practical guide for incoming basileus students and staff. www.basileus.ugent.be/.../File/BASILEUS/Study\%20Guide.doc

Система образования республики Казахстан. Контроль и оценка знаний в высших учебных заведениях. Основные положения. 2007. Available from Internet: $<$ http://www.kti.kz/emer/view_normdoc.php?id=3>. 


\section{Autoriaus publikaciju disertacijos tema sąrašas}

\section{Straipsniai recenzuojamuose mokslo žurnaluose}

Lieponienè, J.; Kulvietienè, R. 2009. Adaptyvios vertinamos veiklos modelis Moodle sistemoje. Lietuvos matematikos rinkinys. 50: 90-95, ISSN 0132-2818. (CIS, MatSciNet, VINITI)

Lieponienè, J.; Kulvietienè, R. 2010. Test based sequecing in SCORM compliant elearning courses. Lietuvos matematikos rinkinys. 51, 121-126, ISSN 0132-2818 (CIS, MatSciNet, VINITI).

Mamčenko, J; Šileikienė, I.; Lieponienė, J.; Kulvietienė, R. 2011. Evaluating the Data of an e-Examination System Using a Descriptive Model in Order to Identify Hidden Patterns in Students Answers. Online Journal on Computer Science and Information Technology, OJCSIT. 1(2), ISSN 2090-4517. (INFOMESR)

Lieponienè, J.; Kulvietienè, R. 2011. The Grades Transfer from One Grading Scale to Other Algorithmization. Informatics in Education. 10(2), 233-244, ISSN 1648-5831. (INSPEC)

Lieponienè, J.; Kulvietienè, R. 2011. The Mathematic Model of Grades Transfer from one Grading Scale to Other. Lietuvos matematikos rinkinys. 52, 116-121, ISSN 01322818. (CIS, MatSciNet, VINITI) 


\section{Straipsniai kituose leidiniuose}

Lieponienè, J. Žinių testavimo sistemos. 2009. Šiuolaikinès technologijos 2009: teorija, praktika, inovacijos. Mokslinès - praktinès konferencijos pranešimu medžiaga. Recenzuojamu straipsniu rinkinys. Kaunas: Kauno kolegija, 37-43, ISBN 978-609-8020-04-5

Lieponienè, J. E. mokymosi rezultatų vertinimo ịrankiai ir jų taikymas žinių ir ịḡažių vertinimui ir vystymui. 2009. Informaciniu technologiju taikymas švietimo sistemoje 2009. Recenzuojamu straipsnių rinkinys. 20-27, ISSN 1822-7244.

Lieponiene, J.; Kulvietiene, R. 2010. The learning path and the research of its efficiency during SCORM compliant e-learning courses. 16 th International Conference on Information and Software Technologies IT 2010 Conference Proceedings. 324-331, ISSN 2029-0063 (Thomson ISI Proceedings).

Kulvietis, G.; Kulvietienè, R.; Lieponienè, J. 2010. Hierarchiniai e. mokymosi kursai koleginių ir universitetinių studijų dalykams suderinti. Informacinés technologijos 2010: teorija, praktika, inovacijos. VIII mokslinès - praktinès konferencijos pranešimu medžiaga. 27-32, ISBN 978-609-8020-10-6.

Lieponienè, J. Mokymosi eigos valdymas SCORM standartą atitinkančiuose e. mokymosi kursuose. 2010. Informacinių technologiju taikymas švietimo sistemoje 2010. Recenzuojamu straipsniu rinkinys. Kaunas: Kauno kolegija, 57-62, ISSN 1822-7244.

Kulvietienè, R.; Lieponienè, J. 2010. Analysis of reached e-education attainment and selected e-learning paths dependency. E-education: Science, Study and Business. 113118, ISBN 978-9955-25-884-1.

J. Mamčenko, I. Šileikienè, J. Lieponienè, R. Kulvietienè. 2011. Analysis of electronic exam data using data mining techniques. 17 th International Conference on Information and Software Technologies IT 2011 Conference Proceedings. 215-219, ISSN 2029-0020 (Thomson ISI Proceedings). 


\section{Priedai}

\section{A priedas. Dviparametrio pažymių konvertavimo modelio testuojamų vertinimo skalių teigiamų pažymių pasiskirstymas}

A.1 lentelè. Pažymių pasiskirstymas vienodo dydžio vertinimo skalèse $A$ ir $B$, kurios neženkliai skiriasi pažymių pasiskirstymu

Table A.1. The grades distribution of grading scales of the same size, and grades distribution of which varies insignificantly

\begin{tabular}{|c|c|c|c|c|c|c|c|c|}
\hline \multirow{2}{*}{$\begin{array}{c}\text { Pažymiŭ } \\
\text { indeksai }\end{array}$} & \multicolumn{6}{|c|}{ Pažymiu pasiskirstymas vertinimo skalèse, \% } \\
\cline { 2 - 10 } & \multicolumn{2}{|c|}{4 balų } & \multicolumn{2}{c|}{6 balų } & \multicolumn{2}{c|}{7 balu } & \multicolumn{2}{c|}{10 balų } \\
\cline { 2 - 10 } & $A$ & $B$ & $A$ & $B$ & $A$ & $B$ & $A$ & $B$ \\
\hline 1 & 2 & 3 & 4 & 5 & 6 & 7 & 8 & 9 \\
\hline 1 & 20 & 15 & 15 & 10 & 5 & 7 & 10 & 8 \\
\hline 2 & 30 & 35 & 15 & 20 & 10 & 11 & 10 & 11 \\
\hline 3 & 30 & 25 & 20 & 15 & 20 & 18 & 10 & 7 \\
\hline 4 & 20 & 25 & 20 & 25 & 30 & 29 & 10 & 13 \\
\hline
\end{tabular}


A.1 lentelès tęsinys

\begin{tabular}{|c|c|c|c|c|c|c|c|c|}
\hline 1 & 2 & 3 & 4 & 5 & 6 & 7 & 8 & 9 \\
\hline 5 & & & 15 & 20 & 20 & 15 & 10 & 8 \\
\hline 6 & & & 15 & 10 & 10 & 15 & 10 & 12 \\
\hline 7 & & & & & 5 & 5 & 10 & 7 \\
\hline 8 & & & & & & & 10 & 13 \\
\hline 9 & & & & & & & 10 & 7 \\
\hline 10 & & & & & & & 10 & 14 \\
\hline
\end{tabular}

A.2 lentelè. Pažymių pasiskirstymas vienodo dydžio vertinimo skalèse $A$ ir $B$, kurios ženkliai skiriasi pažymių pasiskirstymu

Table A.2. The grades distribution of grading scales of the same size, and grades distribution of which varies significantly

\begin{tabular}{|c|c|c|c|c|c|c|c|c|}
\hline \multirow{2}{*}{$\begin{array}{c}\text { Pažymių } \\
\text { indeksai }\end{array}$} & \multicolumn{6}{|c|}{ Pažymių pasiskirstymas vertinimo skalèse, \% } \\
\cline { 2 - 9 } & \multicolumn{2}{|c|}{4 balų } & \multicolumn{2}{c|}{6 balų } & \multicolumn{2}{c|}{7 balu } & \multicolumn{2}{c|}{10 balu } \\
\cline { 2 - 9 } & $A$ & $B$ & $A$ & $B$ & $A$ & $B$ & $A$ & $B$ \\
\hline 1 & 40 & 20 & 20 & 10 & 10 & 5 & 10 & 13 \\
\hline 2 & 20 & 25 & 15 & 20 & 10 & 10 & 10 & 14 \\
\hline 3 & 20 & 25 & 15 & 15 & 15 & 15 & 10 & 11 \\
\hline 4 & 20 & 30 & 20 & 25 & 30 & 35 & 10 & 9 \\
\hline 5 & & & 15 & 20 & 20 & 15 & 10 & 8 \\
\hline 6 & & & 15 & 10 & 10 & 15 & 10 & 13 \\
\hline 7 & & & & & 5 & 5 & 10 & 13 \\
\hline 8 & & & & & & & 10 & 11 \\
\hline 9 & & & & & & & 10 & 3 \\
\hline 10 & & & & & & & 10 & 5 \\
\hline
\end{tabular}


A.3 lentelè. Pažymių pasiskirstymas skirtingo dydžio vertinimo skalèse $A$ ir $B$ Table A.3. The grades distribution of grading scales of the different size

\begin{tabular}{|c|c|c|c|c|c|c|}
\hline \multirow{2}{*}{$\begin{array}{c}\text { Pažymiŭ } \\
\text { indeksai }\end{array}$} & \multicolumn{5}{|c|}{ Pažymių pasiskirstymas vertinimo skalèse, \% } \\
\cline { 2 - 7 } & 4 & $B$ & \multicolumn{2}{|c|}{7 ir 5 balų } & \multicolumn{2}{c|}{10 ir 3 balų } \\
\hline & $A$ & $A$ & $B$ & $A$ & $B$ \\
\hline 1 & 20 & 30 & 5 & 10 & 10 & 30 \\
\hline 2 & 30 & 40 & 10 & 20 & 10 & 40 \\
\hline 3 & 30 & 30 & 20 & 40 & 10 & 30 \\
\hline 4 & 20 & & 30 & 20 & 10 & \\
\hline 5 & & & 20 & 10 & 10 & \\
\hline 6 & & & 10 & & 10 & \\
\hline 7 & & & 5 & & 10 & \\
\hline 8 & & & & & 10 & \\
\hline 9 & & & & & 10 & \\
\hline 10 & & & & & 10 & \\
\hline
\end{tabular}




\section{B priedas. Triparametrio pažymių konvertavimo modelio konvertuojamų pažymių aibių duomenų pasiskirstymas}

B.1 lentelė. Konvertuojamos pažymių aibės duomenų pasiskirstymas, konvertuojant pažymius vienodo dydžio vertinimo skalèse 1-uoju testavimo atveju

Table B.1. Distribution of convertible grades sets data, while conversion of grades is carried out on grading scales of the same size in the first test case

\begin{tabular}{|c|c|c|c|c|}
\hline \multirow{2}{*}{$\begin{array}{c}\text { Pažymių } \\
\text { indeksai }\end{array}$} & \multicolumn{4}{|c|}{ Pažymių pasiskirstymas vertinimo skalèse, \% } \\
\cline { 2 - 5 } & 4 balų & 6 balų & 7 balų & 10 balų \\
\hline 1 & 20 & 15 & 5 & 9 \\
\hline 2 & 20 & 15 & 10 & 11 \\
\hline 3 & 30 & 15 & 20 & 7 \\
\hline 4 & 30 & 25 & 25 & 13 \\
\hline 5 & & 15 & 20 & 9 \\
\hline 6 & & 15 & 15 & 7 \\
\hline 7 & & & 5 & 13 \\
\hline 8 & & & & 10 \\
\hline 9 & & & & 10 \\
\hline 10 & & & & \\
\hline
\end{tabular}

B.2 lentelė. Konvertuojamos pažymių aibès duomenų pasiskirstymas konvertuojant pažymius vienodo dydžio vertinimo skalèse 2-uoju testavimo atveju

Table B.2. Distribution of convertible grades sets data while conversion of grades is carried out on grading scales of the same size in the second test case

\begin{tabular}{|c|c|c|c|c|}
\hline \multirow{2}{*}{$\begin{array}{c}\text { Pažymių } \\
\text { indeksai }\end{array}$} & \multicolumn{4}{|c|}{ Pažymių pasiskirstymas vertinimo skalèse, \% } \\
\cline { 2 - 5 } & 4 balų & 6 balų & 7 balų & 10 balų \\
\hline 1 & 2 & 3 & 4 & 5 \\
\hline 1 & 37 & 5 & 33 & 19 \\
\hline 2 & 13 & 47 & 15 & 18 \\
\hline 3 & 13 & 33 & 19 & 10 \\
\hline
\end{tabular}


B.2 lentelès tesinys

\begin{tabular}{|c|c|c|c|c|}
\hline 1 & 2 & 3 & 4 & 5 \\
\hline 4 & 37 & 5 & 15 & 5 \\
\hline 5 & & 5 & 11 & 5 \\
\hline 6 & & 5 & 3 & 13 \\
\hline 7 & & & 4 & 10 \\
\hline 8 & & & & 5 \\
\hline 9 & & & & 5 \\
\hline 10 & & & & \\
\hline
\end{tabular}

B.3 lentelė. Konvertuojamos pažymių aibès duomenų pasiskirstymas konvertuojant pažymius vienodo dydžio vertinimo skalèsė 3-uoju testavimo atveju

Table B.3. Distribution of convertible grades sets data while conversion of grades is carried out on grading scales of the same size in the third test case

\begin{tabular}{|c|c|c|c|c|}
\hline \multirow{2}{*}{$\begin{array}{c}\text { Pažymių } \\
\text { indeksai }\end{array}$} & \multicolumn{4}{|c|}{ Pažymių pasiskirstymas vertinimo skalèse, \% } \\
\cline { 2 - 5 } & 4 balų & 6 balų & 7 balų & 10 balų \\
\hline 1 & 38 & 20 & 10 & 10 \\
\hline 2 & 22 & 15 & 10 & 8 \\
\hline 3 & 15 & 15 & 20 & 12 \\
\hline 4 & 25 & 18 & 20 & 12 \\
\hline 5 & & 19 & 20 & 8 \\
\hline 6 & & 13 & 10 & 10 \\
\hline 7 & & & 10 & 8 \\
\hline 8 & & & & 10 \\
\hline 9 & & & & \\
\hline 10 & & & & \\
\hline
\end{tabular}


B.4 lentelè. Konvertuojamos pažymių aibės duomenų pasiskirstymas konvertuojant pažymius vienodo dydžio vertinimo skalèsè 4-uoju testavimo atveju

Table B.4. Distribution of convertible grades sets data while conversion of grades is carried out on grading scales of the same size in the fourth test case

\begin{tabular}{|c|c|c|c|c|}
\hline \multirow{2}{*}{$\begin{array}{c}\text { Pažymiŭ } \\
\text { indeksai }\end{array}$} & \multicolumn{4}{|c|}{ Pažymių pasiskirstymas vertinimo skalėse, \% } \\
\cline { 2 - 5 } & 4 balų & 6 balų & 7 balų & 10 balų \\
\hline 1 & 7 & 6 & 20 & 5 \\
\hline 2 & 13 & 12 & 10 & 13 \\
\hline 3 & 50 & 5 & 10 & 5 \\
\hline 4 & 30 & 17 & 20 & 12 \\
\hline 5 & & 20 & 20 & 17 \\
\hline 6 & & 40 & 10 & 8 \\
\hline 7 & & & 10 & 10 \\
\hline 8 & & & & 10 \\
\hline 9 & & & & 13 \\
\hline 10 & & & & \\
\hline
\end{tabular}

B.5 lentelè. Konvertuojamos pažymių aibės duomenų pasiskirstymas konvertuojant pažymius skirtingo dydžio vertinimo skalėsè 1-uoju testavimo atveju

Table B.5. Distribution of convertible grade set data while conversion of grades is carried out on the grading scales of the different size in the first test case

\begin{tabular}{|c|c|c|c|}
\hline \multirow{2}{*}{$\begin{array}{c}\text { Pažymių } \\
\text { indeksai }\end{array}$} & \multicolumn{3}{|c|}{ Pažymių pasiskirstymas vertinimo skalèse, $\%$} \\
\cline { 2 - 4 } & 3 balų & 5 balų & 10 balų \\
\hline 1 & 2 & 3 & 4 \\
\hline 1 & 14 & 6 & 13 \\
\hline 2 & 26 & 12 & 8 \\
\hline 3 & 33 & 17 & 10 \\
\hline 4 & 27 & 25 & 11 \\
\hline 5 & & 20 & 9 \\
\hline 6 & & 15 & 14 \\
\hline 7 & & 5 & 9 \\
\hline 8 & & & 7 \\
\hline
\end{tabular}


B.5 lentelès tęsinys

\begin{tabular}{|c|c|c|c|}
\hline 1 & 2 & 3 & 4 \\
\hline 9 & & & 10 \\
\hline 10 & & & 9 \\
\hline
\end{tabular}

B.6 lentelè. Konvertuojamos pažymių aibės duomenų pasiskirstymas konvertuojant pažymius skirtingo dydžio vertinimo skalèsė 2-uoju testavimo atveju

Table B.6. Distribution of convertible grade set data while conversion of grades is carried out on the grading scales of the different size in the second test case

\begin{tabular}{|c|c|c|}
\hline \multirow{2}{*}{ Pažymių indeksai } & \multicolumn{2}{|c|}{ Pažymių pasiskirstymas vertinimo skalèse, \% } \\
\cline { 2 - 3 } & 3 balų & 5 balų \\
\hline 1 & 27 & 13 \\
\hline 2 & 41 & 17 \\
\hline 3 & 32 & 39 \\
\hline 4 & & 20 \\
\hline 5 & & 11 \\
\hline
\end{tabular}

B.7 lentelè. Konvertuojamos pažymių aibès duomenų pasiskirstymas konvertuojant pažymius skirtingo dydžio vertinimo skalèsè 3-uoju testavimo atveju

Table B.7. Distribution of convertible grade set data while conversion of grades is carried out on the grading scales of the different size in the third test case

\begin{tabular}{|c|c|c|c|}
\hline \multirow{2}{*}{$\begin{array}{c}\text { Pažymių } \\
\text { indeksai }\end{array}$} & \multicolumn{3}{|c|}{ Pažymių pasiskirstymas vertinimo skalèse, \% } \\
\cline { 2 - 4 } & 3 balų & 5 balų & 10 balų \\
\hline 1 & 43 & 23 & 26 \\
\hline 2 & 23 & 9 & 5 \\
\hline 3 & 21 & 17 & 10 \\
\hline 4 & 13 & 14 & 8 \\
\hline 5 & & 23 & 3 \\
\hline 6 & & 9 & 11 \\
\hline 7 & & 5 & 9 \\
\hline 8 & & & 19 \\
\hline 9 & & & 5 \\
\hline 10 & & & \\
\hline
\end{tabular}


B.8 lentelè. Konvertuojamos pažymių aibės duomenų pasiskirstymas konvertuojant pažymius skirtingo dydžio vertinimo skalèsè 4-uoju testavimo atveju

Table B.8. Distribution of convertible grade set data while conversion of grades is carried out on the grading scales of the different size in the fourth test case

\begin{tabular}{|c|c|c|}
\hline \multirow{2}{*}{ Pažymių indeksai } & \multicolumn{2}{|c|}{ Pažymių pasiskirstymas vertinimo skalėse, \% } \\
\cline { 2 - 3 } & 3 balų vertinimo skalė & 5 balų vertinimo skale \\
\hline 1 & 14 & 5 \\
\hline 2 & 40 & 25 \\
\hline 3 & 46 & 37 \\
\hline 4 & & 21 \\
\hline 5 & & 12 \\
\hline
\end{tabular}




\author{
Jurgita LIEPONIENÉ \\ E. MOKYMOSI REZULTATŲ VERTINIMO \\ TECHNOLOGIJŲ TYRIMAS \\ Daktaro disertacija \\ Technologijos mokslai, \\ informatikos inžinerija (07T)
}

\author{
THE RESEARCH OF E-LEARNING RESULTS' \\ ASSESSMENT TECHNOLOGIES \\ Doctoral Dissertation \\ Technological Sciences, \\ Informatic Engineering (07T)
}

201205 04. 12,5 sp. I. Tiražas 20 egz.

Vilniaus Gedimino technikos universiteto

leidykla „Technika“,

Saulètekio al. 11, 10223 Vilnius,

http://leidykla.vgtu.lt

Spausdino UAB "Ciklonas"

J. Jasinskio g. 15, 01111 Vilnius 